Published in final edited form as:

Cochrane Database Syst Rev. ; (3): CD006529. doi:10.1002/14651858.CD006529.pub2.

\title{
Milnacipran versus other antidepressive agents for depression
}

\author{
Atsuo Nakagawa ${ }^{1}$, Norio Watanabe ${ }^{2}$, Ichiro M Omori ${ }^{3}$, Corrado Barbui ${ }^{4}$, Andrea Cipriani ${ }^{4}$, \\ Hugh McGuire $^{5}$, Rachel Churchill ${ }^{6}$, and Toshi A Furukawa ${ }^{2}$ \\ ${ }^{1}$ Department of Psychiatry, Keio University School of Medicine, Tokyo, Japan \\ ${ }^{2}$ Department of Psychiatry \& Cognitive-Behavioral Medicine, Nagoya City University Graduate \\ School of Medical Sciences, Nagoya, Japan \\ ${ }^{3}$ Cochrane Schizophrenia Group, University of Nottingham, Nottingham, UK \\ ${ }^{4}$ Department of Medicine and Public Health, Section of Psychiatry and Clinical Psychology, \\ University of Verona, Verona, Italy \\ ${ }^{5}$ National Coordinating Centre for Women and Child Health, London, UK \\ ${ }^{6}$ Academic Unit of Psychiatry, Community Based Medicine, University of Bristol, Bristol, UK
}

\begin{abstract}
Background-Although pharmacological and psychological interventions are both effective for major depression, antidepressant drugs are frequently used as first-line treatment in primary and secondary care settings. Milnacipran, a dual serotonin-norepinephrine reuptake inhibitor (SNRI), is one of the antidepressant drugs that clinicians use for routine depression care.
\end{abstract}

Objectives-To assess the evidence for the efficacy, acceptability and tolerability of milnacipran in comparison with tricyclic antidepressants (TCAs), heterocyclics, SSRIs and other newer antidepressive agents in the acute-phase treatment of major depression.

Search methods-The Cochrane Collaboration Depression, Anxiety \& Neurosis review group Controlled Trials Register (CCDANCTR-Studies and CCDANCTR-References) were electronically searched in August 2008. References of relevant trials and other reviews were also checked. Trial databases of the drug-approving agencies and ongoing clinical trial registers for all

Copyright $\odot 2009$ The Cochrane Collaboration. Published by John Wiley \& Sons, Ltd

Contact address: Atsuo Nakagawa, Department of Psychiatry, Keio University School of Medicine, Shinanomachi 35, Shinjuku-ku,

Tokyo, 160-8582, Japan. nakagawa@keio-psychiatry.com.

Editorial group: Cochrane Depression, Anxiety and Neurosis Group.

Publication status and date: New, published in Issue 3, 2009.

Review content assessed as up-to-date: 31 July 2008.

CONTRIBUTIONS OF AUTHORS

AN, NW, TAF, AC, CB, RC and HMG conceived and designed the review. AN, NW and HMG identified and acquired reports of trials, and contacted authors of trials and pharmaceutical industries for additional information. AN and NW extracted data. AN, NW and TAF analysed and interpreted the data. AC, $\mathrm{CB}$ and $\mathrm{HMG}$ contributed to the interpretation of the data. AN wrote the first draft of the manuscript. All authors contributed to make critical revision of the manuscript for important intellectual content and have approved the final version of the manuscript.

DECLARATIONS OF INTEREST

AN, NW, AC, CB, HMG, RC: none declared

TAF has received several research grants and fees for speaking from some pharmaceutical companies, which market antidepressants (paroxetine, fluvoxamine, milnacipran, trazodone, mianserin), antipsychotics (risperidone, olanzapine, quetiapine, paliperidone, asenapine), nootropics (donepezil) and anxiolytics (loflazepate, tandospirone). 
published and unpublished trials were handsearched in 2007. All relevant authors were contacted for supplemental data. No language restriction was applied.

Selection criteria-Randomised controlled trials comparing milnacipran with any other active antidepressive agents (including non-conventional agents such as herbal products like hypericum) as monotherapy in the acute phase of major depression were selected.

Data collection and analysis-Two reviewers independently checked eligibility, assessed methodological quality and extracted data from the eligible trials using a standardised data extraction form. The number of participants who responded to treatment or those who achieved remission were calculated on an intention-to-treat basis. Random-effects meta-analyses were conducted, combining data from the included trials.

Main results-A total of 16 randomised controlled trials $(n=2277)$ were included in the metaanalysis. Despite the size of this sample, the pooled $95 \%$ confidence intervals were rather wide and there were no statistically significant differences in efficacy, acceptability and tolerability when comparing milnacipran with other antidepressive agents. However, compared with TCAs, patients taking milnacipran were associated with fewer dropouts due to adverse events (OR 0.55; $95 \%$ CI 0.35 to 0.85 ). There was also some weak evidence to suggest that patients taking milnacipran experienced fewer adverse events of sleepiness/drowsiness, dry mouth or constipation compared with TCAs.

Authors' conclusions-Currently, there is inadequate evidence to conclude whether milnacipran is superior, inferior or the same as other antidepressive agents in terms of efficacy, acceptability and tolerability in the acute phase treatment of major depression. However, there is some evidence in favour of milnacipran over TCAs in terms of dropouts due to adverse events (acceptability) and the rates of experiencing adverse events (tolerability). Information about other clinically meaningful outcomes such as cost-effectiveness and social functioning, including the ability to return to work, is lacking. Further study is needed to answer whether milnacipran would be the better choice of antidepressant for acute major depression.

\section{Medical Subject Headings (MeSH)}

Antidepressive Agents [adverse effects; *therapeutic use]; Cyclopropanes [adverse effects; *therapeutic use]; Depressive Disorder, Major [* drug therapy]; Randomized Controlled Trials as Topic; Serotonin Uptake Inhibitors [adverse effects; *therapeutic use]

\section{MeSH check words}

Humans

\section{BACKGROUND}

\section{Description of the condition}

Major depression, also known as major depressive disorder or unipolar depression, is a common metal disorder characterised by a combination of persistent symptoms (including depressed mood, loss of interest, loss of appetite, insomnia, fatigue, poor concentration, extreme guilt and suicide ideation) that interfere with a person's ability to work, study and 
enjoy pleasurable activities (APA 1994). Compared with other medical diagnoses, depression is very common. Lifetime prevalence estimates for major depression in the community range from 15 to 17\% (APA 1994), 12-month prevalence from 6 to $7 \%$ (Kessler 2003). The prevalence of major depression in the medical outpatient is 5 to $13 \%$ (Coyne 1994). Major depression is the third leading cause of burden among all diseases after lower respiratory infections and diarrhoeal diseases, accounting for $4.3 \%$ of human suffering in terms of illhealth; moreover, it is expected to show a rising trend during the coming 20 years (WHO 2004). This condition is associated with a marked personal, social and economic morbidity, loss of functioning and productivity, and creates significant demands on service providers in terms of workload (NICE 2007). In the USA, the economic burden of depression has been estimated at just over $\$ 83$ billion in 2000 , of which $\$ 26$ billion were direct treatment costs, $\$ 5$ billion were suicide-related costs, and $\$ 52$ billion were workplace costs (Greenberg 2003). It is also suspected that these figures are still underestimates of the true economic burden of the disease, which may in addition involve burden on family members and caregivers, the cost of lost productivity while at work, and cost associated with those who remain untreated (Greenberg 2005).

\section{Description of the intervention}

Although pharmacological and psychological interventions are both effective for major depression, in primary and secondary care settings antidepressant (AD) drugs remain the mainstay of treatment (APA 2000; Ellis 2004; NICE 2007) (see below for other references to the relevant evidence). Amongst ADs many different agents are available, including tricyclic antidepressants (TCAs), monoamine oxidase inhibitors (MAOIs), selective serotonin reuptake inhibitors (SSRIs), serotonin-noradrenaline reuptake inhibitors (SNRIs: venlafaxine, duloxetine, milnacipran), and other newer agents (mirtazapine, reboxetine, bupropion). In many western countries, during the last 20 years, ADs consumption has dramatically risen, mainly because of the increasing consumption of SSRIs and newer ADs, which have progressively become the most commonly prescribed ADs (Ciuna 2004; Guaiana 2005). SSRIs are generally better tolerated than TCAs (Barbui 2007), and there is evidence of similar efficacy (Anderson 2000a; Geddes 2000; Williams 2000). However, head-to-head comparisons provide contrasting findings. Amitriptyline, for example, may have the edge over SSRIs in terms of efficacy (Guaiana 2007), and individual SSRIs and SNRIs may differ in terms of efficacy and tolerability (Cipriani 2005; Smith 2002).

\section{How the intervention might work}

Milnacipran has been available as an antidepressant since 1997 in many countries including France and Japan (34 countries and regions as of 2006). Milnacipran appears to act exclusively at presynaptic sites to inhibit noradrenaline (norepinephrine) and serotonin uptake (Moret 1985), but unlike TCAs, has no significant effect on any neurotransmitter receptor (Briley 1996). Thus, compared with TCAs, milnacipran has shown a lower incidence of anticholinergic-like side effects, less sedation due to histamine H1-receptor binding and lower incidence of postural hypotension due to alpha-1 adrenoceptor antagonism (Spencer 1998). The pharmacokinetic profile of the drug indicates that milnacipran has a high bioavailability, low plasma protein binding (13\%) and is mostly eliminated in urine: $50 \%$ as the unchanged drug, $30 \%$ as a glucuronide (main metabolite) 
and the remaining $20 \%$ by oxidative transformation (Puozzo 1996). Milnacipran does not affect the activities of CYP-2D6, 2C19, 1A2 and 3A4 isoforms, and its pharmacokinetics are not modified in poor metabolizers of CYP-2D6 and CYP-2C9 (Puozzo 1996; Sawada 2001; Puozzo 2005). Furthermore, studies in patients with liver dysfunction suggest that dose adjustment is not necessary or to be minor when milnacipran is administered to these patients (Puozzo 1996).

\section{Why it is important to do this review}

Given that the most recent available evidence refers to the SSRIs as an homogeneous group (Arroll 2005; Geddes 2000; Hansen 2005), it is still unclear how each newer antidepressive agent compares with other antidepressants in terms of effects and adverse events. A group of researchers therefore agreed to join forces under the rubric of the Multiple meta-Analyses of New Generation Antidepressants (MANGA) Study to systematically review all available evidence for each specific newer antidepressant.

In terms of milnacipran, only limited evidence has been established regarding the efficacy, acceptability and tolerability in comparison with other antidepressive agents, to date. Some RCTs have reported that milnacipran has an antidepressant efficacy similar to other antidepressants, such as imipramine (Tignol 1998; Van Amerongen 2002; Lopez-Ibor 2004), clomipramine (Leinonen 1997; Steen 1997), fluoxetine (Guelfi 1998), fluvoxamine (Clerc 2001) and paroxetine (Sechter 2004). In a systematic review (Puech 1997), milnacipran has shown superior antidepressant efficacy in comparison with SSRIs and the tolerability has been comparable to that of the SSRIs. However, this review was sponsored by a pharmaceutical company marketing milnacipran and was published more than a decade ago. Therefore, there is a good reason to conduct an up-to-date comprehensive systematic quantitative review using currently best-available evidence on comparative efficacy and adverse effects of milnacipran against other antidepressive agents.

The primary objective of this systematic review is to assess the evidence for the efficacy, acceptability and tolerability of milnacipran in comparison with TCAs, heterocyclics, SSRIs and other newer antidepressive agents, including non-conventional agents, in the acutephase treatment of major depression.

\section{OBJECTIVES}

1. To determine the efficacy of milnacipran in comparison with other antidepressive agents in alleviating the acute symptoms of depression.

2. To review acceptability of treatment with milnacipran in comparison with other antidepressive agents.

3. To investigate the adverse effects of milnacipran in comparison with other antidepressive agents. 


\section{METHODS}

\section{Criteria for considering studies for this review}

Types of studies-Only randomised controlled trials were included. Quasi-randomised trials, such as those allocating by using alternate days of the week, were excluded. For trials which have a crossover design only results from the first randomisation period were considered.

Types of participants-Patients aged 18 or older, of both sexes with a primary diagnosis of major depression. Studies adopting any standardised criteria to define patients suffering from unipolar major depression were included. Studies from the 1990s onwards were likely to have used DSM-IV (APA 1994) or ICD-10 (WHO 1992) criteria. Ealier studies may have used ICD-9 (WHO 1978), DSM-III (APA 1980)/DSM-III-R (APA 1987) or other diagnostic systems. ICD-9 is not operationalised criteria, because it has only disease names and no diagnostic criteria, so studies using ICD-9 were excluded. On the other hand, studies using Feighner Criteria or Research Diagnostic Criteria were included. We included the following depression subtypes: chronic, with catatonic features, with melancholic features, with atypical features, with postpartum onset, and with seasonal pattern. Studies in which less than $20 \%$ of the participants may be suffering from bipolar depression were included. A concurrent secondary diagnosis of another psychiatric disorder was not considered as exclusion criteria.

Major depression with psychotic features were excluded. A concurrent primary diagnosis of Axis I or II disorders was an exclusion criteria. Antidepressant trials in depressive patients with a serious concomitant medical illness were also excluded.

\section{Types of interventions}

Experimental intervention: Milnacipran (as monotherapy). No restrictions on dose, frequency, intensity and duration were applied.

Comparator intervention: Other active agents in the treatment of acute major depression, including:

1. TCAs (imipramine, clomipramine, amitriptyline)

2. Heterocyclic antidepressants (mianserin)

3. SSRIs (fluvoxamine, fluoxetine, paroxetine, sertraline, citalopram, escitalopram)

4. Newer antidepressants (SNRIs such as venlafaxine and duloxetine, MAOIs or newer agents such as mirtazapine, bupropion, reboxetine

5. Non-conventional antidepressive agents such as herbal products like hypericum (Linde 2008) and fish oil (Appleton 2006).

No restrictions on dose, frequency, intensity and duration were applied. 
Other type of psychopharmacological agent such as anxiolytics, antic-convulsants, antipsychotics or mood-stabilizers were excluded. Trials in which milnacipran was used as an augmentation strategy were excluded. Placebo-controlled trials were also excluded.

Types of outcome measures-Efficacy, acceptability and tolerability during and at the end of acute-phase treatment trials, defined as 6 to 12 weeks, was our outcome of interest. However, when data from trials longer than 12 weeks were available, we also included them.

Primary outcomes: Number of patients who responded to treatment, showing a reduction of at least 50\% on the Hamilton Rating Scale of Depression (HAM-D) (Hamilton 1960) or Montgomery-Asberg Depression Scale (MADRS) (Montgomery 1979), or "much or very much improved" (score 1 or 2) on CGI-Improvement (Guy 1970) out of the total number of randomised patients. HAM-D has been the golden standard measure of depression severity for the clinical trials of antidepressants (Williams 2001).Therefore, we used the HAM-D for judging response whenever possible, even when we needed to impute SDs or response rates according to the procedures described in the Methods below.

When studies reported response rates at various time points of the trial, we subdivided the treatment indices as follows, according to criteria decided a priori:

1. Early phase treatment: between 1 and 4 weeks (preference was given to the time point closest to 2 weeks);

2. Acute phase treatment: between 6 and 12 weeks (preference was given to the study endpoint);

3. Follow-up phase treatment: between 4 and 6 months (preference was given to the time point closest to 24 weeks)..

\section{Secondary outcomes}

1. Number of patients who achieved remission. The cutoff point for remission was set a priori (1) at 7 or less for the 17-item HAM-D and at 8 or less for all the other longer versions of HAM-D, or (2) at 12 or less on the MADRS (Zimmerman 2004), or (3) "not ill or borderline mentally ill" (score 1 or 2) on CGI-Severity (Guy 1970). We used the HAM-D for judging remission whenever possible.

2. Severity of depression at the end of the trial as measured on continuous scale such as HAM-D, MADRS, etc. We applied 'loose' ITT analyses, whereby all the patients with at least one post-baseline measurement were represented by their last observations carried forward.

3. Social adjustment, social functioning including the Global Assessment of Function (GAF) (Luborsky 1962) scores.

4. Health-related quality of life: We will limit ourselves to SF-12/SF-36 (Ware 1993), HoNOS (Wing 1994) and WHO-QOL (WHOQOL Group 1998).

5. Costs to health care services 
6. Acceptability measures

i. Number of patients who dropped out during the trial as a proportion of the total number of randomised patients - due to any cause

ii. Number of patients who dropped out during the trial as a proportion of the total number of randomised patients - due to inefficacy

iii. Number of patients who dropped out during the trial as a proportion of the total number of randomised patients - due to adverse events

7. Tolerability measures:

i. Total number of patients experiencing at least some adverse events

ii. Total number of patients experiencing the following specific adverse events was sought for:
a. sleepiness/drowsiness
b. insomnia
c. dry mouth
d. constipation
e. urination problems
f. hypotension
g. agitation/anxiety
h. suicide wishes/gestures/attempts
i. completed suicide
j. $\quad$ vomiting/nausea
k. diarrhoea

In order not to miss any relatively rare or unexpected yet important adverse events, in the data extraction phase, we collected all adverse event data reported in the literature and discussed ways to summarize them post hoc.

\section{Search methods for identification of studies}

Electronic searches-We searched using the Cochrane Collaboration Depression, Anxiety \& Neurosis Controlled Trials Registers (CCDANCTR-Studies and CCDANReferences) (searched in December 2006; updated in August 2008). This register of randomised controlled trials is compiled by methodical searches of CENTRAL, AMED, CINAHL, EMBASE, LiLACS, MEDLINE, PSYCINFO, PSYN-DEX supplemented with hand searching of both journals and conference proceedings.

CCDANCTR-Studies were searched using the following search strategy:

Diagnosis $=$ Depress* or Dysthymi* or "Adjustment Disorder*" or "Mood Disorder*" or "Affective Disorder" or "Affective Symptoms" 
and Intervention $=$ Milnacipran

CCDANCTR-References were searched using the following search strategy:

Keyword = Depress* or Dysthymi* or "Adjustment Disorder*" or "Mood Disorder*" or "Affective Disorder" or "Affective Symptoms"

and Free-Text $=$ Milnacipran

Trial databases of the following drug-approving agencies - (the Food and Drug Administration (FDA) in the USA, the Medicines and Healthcare products Regulatory Agency (MHRA) in the UK, the European Medicines Agency (EMEA) in the EU, the Pharmaceuticals and Medical Devices Agency (PMDA) in Japan, the Therapeutic Goods Administration (TGA) in Australia and ongoing trial registers (clinicaltrials.gov in the USA, ISRCTN and National Research Register in the UK, Nederlands Trial Register in the Netherlands, EUDRACT in the EU, UMIN-CTR in Japan and the Australian Clinical Trials Registry in Australia) were handsearched for published, unpublished and ongoing controlled trials

\section{Searching other resources}

Hand-searching: Appropriate journals and conference proceedings relating to milnacipran treatment for depression have been hand-searched and incorporated into the CCDANCTR databases up until August 2008.

Personal communications: Pharmaceutical companies and experts in this field were asked if they knew of any study which meets the inclusion criteria of this review (contacted in May 2007).

Reference lists: Reference lists of the included studies, previous systematic reviews and major textbooks of affective disorder written in English were checked for published reports and citations of unpublished research. The reference of all included studies were checked via Science Citation Index for articles which had cited the included study.

\section{Data collection and analysis}

Selection of studies-Studies relating to milnacipran generated by the electronic search of the CCDANCTR-Studies were scanned by one review authors (HMG).Full texts were retrieved of all those studies which met the following rough inclusion criteria:

1. Randomized trial

2. Comparing milnacipran against any other antidepressive agents

3. Patients with depression, regardless of the diagnostic criteria used.

Studies relating to milnacipran generated by the search strategies of the CCDANCTRReferences and the other complementary searches were checked by the CCDAN Trial Search Coordinator (HMG), who is an author of this review, and another independent review author (AN and NW) to see if they met the inclusion criteria, firstly based on the title 
and abstracts. All the studies rated as possible candidates by either of the two reviewers (AN and NW) were added to the preliminary list and their full texts were retrieved. All the full text articles in this preliminary list were then assessed by two review authors (AN and NW) independently to see if they met strict inclusion criteria. If the raters disagreed the final rating was made by consensus with the involvement (if necessary) of another member of the review group. Non-congruence in selection of trials were reported as percentage disagreement. Considerable care was taken to exclude duplicate publications.

Data extraction and management-One review author (AN) first extracted data concerning participant characteristics (age, sex, depression diagnosis, comorbidity, depression severity, antidepressant treatment history for the index episode, study setting), intervention details (intended dosage range, mean daily dosage actually prescribed, cointervention if any, milnacipran as investigational drug or as comparator drug, sponsorship) and outcome measures of interest from the included studies. We planned at protocol stage to compare results with those in relevant completed reviews of individual antidepressants in the Cochrane Library and feed back any discrepancies to their authors: in the event, there were insufficient existing reviews to make this possible.

Assessment of risk of bias in included studies-We used the Cochrane risk-of-bias tool as recommended in RevMan 5.0.0 (Higgins 2008a; Higgins 2008b). This instrument consists of six items. Two of the items assess the strength of the randomisation process in preventing selection bias in the assignment of participants to interventions: adequacy of sequence generation and allocation concealment. The third item (blinding) assesses the influence of performance bias on the study results. The fourth item assesses the likelihood of incomplete outcome data, which raise the possibility of bias in effect estimates. The fifth item assesses selective reporting, the tendency to preferentially report statistically significant outcomes. It requires a comparison of published data with trial protocols, when such are available. The final item refers to other sources of bias that are relevant in certain circumstances, for example, in relation to trial design (methodological issues such as those related to crossover designs and early trial termination) or setting.

Two independent review authors (AN and NW) assessed risk of bias in each trial independently, in accordance with the Cochrane Handbook (Higgins 2008a). Where inadequate details of allocation concealment and other characteristics of trials were provided, the authors were contacted in order to obtain further information. If the raters disagreed the final rating was made by consensus with the involvement (if necessary) of another member of the review group.

Measures of treatment effect-Data were checked and entered into RevMan 5 software by two review authors (AN and NW) (double data entry). For dichotomous, or event-like data, odds ratios (OR) were calculated with $95 \%$ confidence intervals. For continuous data, weighted mean differences (WMD) or standardized mean differences (SMD) (where different measurement scales are used) were calculated with $95 \%$ confidence intervals.

Unit of analysis issues-We planned at protocol stage to compare results from the initial randomisation phase of a crossover trial or a trial involving three (or more)-armed 
trial with a placebo arm. However, none of the included studies required implementation of these plans.

Dealing with missing data-Responders and remitters to treatment were calculated on an intention-to-treat (ITT) basis: drop-outs were always included in this analysis. Where participants had withdrawn from the trial before the endpoint, it was assumed they would have experienced the negative outcome by the end of the trial (e.g. failure to respond to treatment). When there were missing data and the method of "last observation carried forward" (LOCF) were been used to do an ITT analysis, then the LOCF data were used, with due consideration of the potential bias and uncertainty introduced. When dichotomous or continuous outcomes were not reported, trial authors were asked to supply these data.

When only the SE or $t$ statistics or $\mathrm{p}$ values were reported, SDs were calculated according to Altman (Altman 1996). In the absence of supplemental data from the authors, the SDs of the HAM-D (or any other depression scale) and response and remission rates were calculated according to validated methods (Furukawa 2005; Furukawa 2006). We examined the validity of these imputation in the sensitivity analyses.

Assessment of heterogeneity-We planned at protocol stage to present the skewed data and nonquantitative data descriptively, however, no such relevant data were identified from the included studies. Should they be identified in future updates, any outcome whose minimum score is zero will be considered skewed when the mean is smaller than twice the SD. Heterogeneity between studies was investigated by the I-squared statistic (I-squared equal to or more than $50 \%$ was considered indicative of heterogeneity) and the p value from the chi-squared test (Higgins 2003), and by visual inspection of the forest plots.

Assessment of reporting biases-Where a sufficient number of trials were available, a funnel plot analysis was performed to check for existence of small study effects including publication bias.

Data synthesis-A random effects model was used to pool the results of single studies, because this model is more conservative than fixed effects model and incorporates both within-study and between-study variance. Further, a random effects model OR was used for the primary analysis rather than a random effect risk ratio (RR) because it has been shown that the highest generalisability in our empirical examination of summary effect measures for meta-analyses (Furukawa 2002a). The robustness of this summary measure was routinely examined by checking the fixed effect model OR and the random effects model RR. Fixed effect analyses were done routinely for the continuous outcomes as well, to investigate the effect of the choice of method on the estimates. Material differences between the models were reported.

Subgroup analysis and investigation of heterogeneity-Subgroup analyses should be performed and interpreted with caution because multiple analyses will lead to false positive conclusions (Oxman 1992). However, we performed the following subgroup analyses, where possible, for the following reasons, which were stated a priori in our protocol. 
1. Milnacipran dosing (fixed low dosage, fixed standard dosage, fixed high dosage; flexible low dosage, flexible standard dosage, flexible high dosage), because there was evidence to suspect that low dosage antidepressant might be associated with better outcomes both in terms of effectiveness and side effects than standard or high dosage antidepressants (Bollini 1999;Furukawa 2002b) and also because fixed versus flexible dosing schedule might affect estimates of treatment effectiveness (Khan 2003). In the case of milnacipran, based on previous reports (Lecrubier 1996; Lopez-Ibor 1996; Okamura 2006), low dosage refers to <100, standard dosage to $>=100$ but $<150$, and high dosage to $>=150 \mathrm{mg} /$ day .

2. Comparator dosing (low effective range, medium to high effective range), as it is easy to imagine that there were greater chances of completing the study on the experimental drug than on the comparator drug that is increased to the maximum dosage.

3. Depression severity (severe major depression, moderate/mild major depression).

4. Treatment settings due to difference in severity of illness (psychiatric inpatients, psychiatric outpatients, primary care).

5. Elderly patients ( $>=65$ years of age), separately from other adult patients

Sensitivity analysis-The following sensitivity analyses were planned a priori. By limiting the studies to be included to those with higher quality, we examined if the results changed, and checked for the robustness of the observed findings.

1. Excluding trials with unclear concealment of random allocation and/or unclear double blinding.

2. Excluding trials whose drop out rate is greater than $20 \%$. Performing the worst case scenario ITT (all the patients in the experimental group experience the negative outcome and all those allocated to the comparison group experience the positive outcome) and the best case scenario ITT (all the patients in the experimental group experience the positive outcome and all those allocated to the comparison group experience the negative outcome).

3. Excluding trials for which the response rates had to be calculated based on the imputation method (Furukawa 2005) and those for which the SD had to be borrowed from other trials (Furukawa 2006).

4. Examination of "wish bias" by comparing milnacipran as investigational drug vs milnacipran as comparator, as there was evidence to suspect that a new antidepressant might perform worse when used as a comparator than when used as an experimental agent (Barbui 2004).

5. Excluding studies funded by the pharmaceutical company marketing milnacipran. This sensitivity analysis was particularly important in view of the recent repeated findings that funding strongly affects outcomes of research studies (Als-Nielsen 2003; Bhandari 2004; Lexchin 2003; Montgomery 2004; Perlis 2005;Procyshyn 
2004) and because industry sponsorship and authorship of clinical trials are increasing over the past 20 years (Buchkowsky 2004).

Our routine application of random effects models as well as our secondary outcomes of remission rates and continuous severity measures may be considered additional forms of sensitivity analyses. At protocol stage we planned (in the event of any of the subgroup or sensitivity analyses turning out to be significant) to run meta-regression for exploratory analyses of their additive or multiplicative influences. However, it was impossible to run any analyses due to non-significant results.

\section{RESULTS}

\section{Description of studies}

See: Characteristics of included studies; Characteristics of excluded studies; Characteristics of studies awaiting classification. See: Characteristics of included studies; Characteristics of excluded studies.

Results of the search-Twenty-nine studies (38 references) were initially identified through an electronic search of the CCDAN register in May 2007 (see above). Seven additional studies were identified through hand search including contact with the manufacturing company of milnacipran (Pierre Fabre). Searches of the CCDAN register were rerun in August 2008 and a further two studies (two references) were identified. After looking over titles and abstracts, 25 studies were considered potentially relevant for further inspection. No ongoing studies were identified; one study currently awaits assessment and its data may appear in an update of this review (Yoshimura 2007).

Included studies-It was possible to include16 randomised controlled trials of milnacipran comparing other antidepressants in the meta-analysis. In total, the studies included 2277 participants. The data reporting of most studies was incomplete even after supplementing the data provided by the two authors (Lee 2002b; Shinkai 2004). Therefore, with three exceptions (Tignol 1998; Sechter 2000; Shinkai 2004), the numbers of patients with response and remission were imputed. Except for Shinkai 2004, all the studies were sponsored by a pharmaceutical company.

Design: The median of number of participants per study was 120 (range: 41-302), and the total participants of the entire study revealed to be 2277 . The mean length of the trial was 7 weeks (SD 5.5). Most of the trials were conducted throughout the acute treatment phase (6 to12 weeks). However, six trials were limited to the early treatment phase (4 weeks: Annseau 1989a; Annseau 1989c; Annseau 1991c; Endo 1995; Shinkai 2004; Yamashita 1995). One trial had a longer length that ran up to 26 weeks (Leinonen 1997).

Milnacipran versus TCAs: Three studies were 4-week trials (Annseau 1989a; Annseau 1989c; Yamashita 1995), two were 6-week trials (Van Amerongen 2002;Lopez-Ibor 2004), one was a 8-week trial (Tignol 1998), and the remaining was a 26-week trial (Leinonen 1997). 
Milnacipran versus heterocyclics: A single study was a 4-week trial (Endo 1995).

Milnacipran versus SSRIs: Two studies were 4-week trials (Annseau 1991c;Shinkai 2004), four were 6-week trials (Annseau 1994; Clerc 2001; Lee 2002b;Sechter 2000), one was a 8week trial (Yang 2003), and the remaining was a 12-week trial (Guelfi 1998a).

Setting: Four studies enrolled out-patients (Annseau 1994; Sechter 2000;Lee 2002b; Yang 2003), five both in- and out-patients (Endo 1995; Yamashita 1995; Leinonen 1997; Tignol 1998; Clerc 2001), while the remaining studies were conducted in in-patient facilities.

Milnacipran versus TCAs: Four studies were recruited in in-patient settings (Annseau 1989a; Annseau 1989c; Van Amerongen 2002; Lopez-Ibor 2004) and three were recruited in both in- and out-patient settings (Leinonen 1997; Tignol 1998; Yamashita 1995).

Milnacipran versus heterocyclics: A single study was recruited in a both in- and out-patient setting (Endo 1995).

Milnacipran versus SSRIs: Three studies were recruited in in-patient settings (Annseau 1991c; Guelfi 1998a; Shinkai 2004), four were recruited in out-patient settings (Annseau 1994; Lee 2002b; Sechter 2000; Yang 2003), and the remaining was recruited in a both inand out-patient setting (Clerc 2001).

\section{Participants}

Diagnosis: The majority of studies enrolled participants with pure unipolar major depression, whilst five studies enrolled participants with major depression that included bipolar depression (less than 20\% of the participants) (Annseau 1994; Yamashita 1995; Leinonen 1997; Tignol 1998; Lopez-Ibor 2004).

Milnacipran versus TCAs: Four studies enrolled patients with unipolar depression (Annseau 1989a; Annseau 1989c; Yamashita 1995; Van Amerongen 2002) while three studies enrolled patients with unipolar or bipolar depression (Leinonen 1997; Tignol 1998; Lopez-Ibor 2004).

Milnacipran versus heterocyclics: Only one study enrolled patients with unipolar depression (Endo 1995).

Milnacipran versus SSRIs: Seven studies enrolled patients with unipolar depression (Annseau 1991c; Guelfi 1998a; Sechter 2000; Clerc 2001; Lee 2002b; Yang 2003; Shinkai 2004) while the remaining study enrolled patients with unipolar or bipolar depression (Annseau 1994).

Age: All participants were aged 18 or above and included some elderly participants (65 years or older). One study by Tignol 1998 was limited only to elderly participants and another study by Yang 2003 did not report age of the participants. 


\section{Interventions}

Comparator intervention: There were seven studies comparing milnacipran with TCAs, one study with heterocyclics, and eight studies with SSRIs. We were not able to identify any study that compared milnacipran with newer antidepressants such as SNRIs, MAOIs or nonconventional antidepressive agents. No study included a placebo arm.

Milnacipran versus TCAs: Four studies compared milnacipran with imipramine (Yamashita 1995; Tignol 1998; Van Amerongen 2002; Lopez-Ibor 2004), two with amitriptyline (Annseau 1989a; Annseau 1989c), and the remaining one with clomipramine (Leinonen 1997). One study (Annseau 1989a) presented a comparison between three arms: milnacipran $50 \mathrm{mg} /$ day, milnacipran $100 \mathrm{mg}$ and amitriptyline $150 \mathrm{mg}$ /day.

Milnacipran versus heterocyclics: Only one study compared milnacipran with mianserin (Endo 1995).

Milnacipran versus SSRIs: Three studies compared milnacipran with fluoxetine (Annseau 1994; Guelfi 1998a; Lee 2002b), two with fluvoxamine (Annseau 1991c; Clerc 2001), two with paroxetine (Sechter 2000; Shinkai 2004), and the remaining one with sertraline (Yang 2003). One study (Guelfi 1998a) presented a comparison between three arms: milnacipran $100 \mathrm{mg} /$ day, milnacipran 200mg and fluoxetine 20mg/day, and other study (Annseau 1991c) presented a comparison between three arms: milnacipran 150-300mg/day, milnacipran $200 \mathrm{mg}$ and fluvoxamine $200 \mathrm{mg} /$ day.

Dosage of the study drugs: In 8 out of the 16 studies, the dosage of milnacipran were within the standard therapeutic range (100-150 mg/day), three within the higher dosage range (>150mg/day) (Annseau 1989c Annseau 1991c; Leinonen 1997), three within the lower dosage range (<100mg/day) (Endo 1995; Yamashita 1995; Shinkai 2004), and the two had combined dosage range due to three arms. Of the combined dosage studies, one study (Annseau 1989a) had one arm within the standard therapeutic range and other in the lower dosage range, and another study (Guelfi 1998a) had one arm within the standard therapeutic range and other in the higher dosage range. On the other hand, the dosage of the comparator drug were within the standard therapeutic range for all the studies, except Clerc 2001 that had higher dosage range and Yamashita 1995 that had lower dosage range.

The use of a fixed- or a flexible-dose regimen was consistent among comparisons within the same study in all of included trials. Six studies (Endo 1995; Yamashita 1995; Leinonen 1997; Tignol 1998; Yang 2003; Shinkai 2004) involved a flexible-dose scheduling design, whereas the remainder of included trials involved a fixed-dose scheduling design.

Outcomes: Outcome concerning efficacy during acute phase treatment (6-12 weeks) were obtained from ten studies $(\mathrm{n}=1565)$. Of the ten studies, six studies were assessed at 6 weeks, 3 at 8 weeks and one at 12 weeks. Efficacy data during early phase were obtained from 13 studies ( $\mathrm{n}=1934)$, and in 11 studies were assessed at two weeks. All studies used intention to treat analyses based on the last observation carried forward method for the efficacy outcome. Either 17, 21 or 24-item HAM-D were used to evaluate the efficacy data for all the studies included in the review. The data reporting of most studies were incomplete even 
after supplementing the provided data from contacted two authors (Lee 2002b; Shinkai 2004). Therefore, with three exceptions (Tignol 1998; Sechter 2000; Shinkai 2004), the number of patients with response and remission were imputed. In terms of acceptability, except for Leinonen 1997, all studies reported the total number of participants who dropped out prematurely during the trial. Yang 2003 did not provide the specific number of participants who dropped out during the study due to inefficacy or side effects. Annseau 1989a also did not provide the number of participants who dropped out during the study due to side effects. Outcome data concerning tolerability were extractable for the majority of studies but were not available for four (Annseau 1994; Leinonen 1997; Shinkai 2004; Yang 2003).

No data were obtained for social adjustment, social functioning, health-related quality of life or costs to health care services from the included studies.

Excluded studies-Of the 25 studies considered for inclusion, 3 studies were excluded because they were additional publications of trials already included (Onodera 1992; Baek 2002b; Lee 2004). Two studies did not use other antidepressant as a comparator drug (Macher 1989; Kanemoto 2004). One study was not randomised (Wyeth 2006). Another study did not use relevant operational diagnostic criteria (Baek 2002a). One study looked at response to drugs by gender (Naito 2007). Finally, one study did not include acute phase treatment (Dardennes 1998). No study was excluded due to having more than $20 \%$ of the participants with bipolar depression as defined in our exclusion criteria. One study remains awaiting assessment (Yoshimura 2007).

\section{Risk of bias in included studies}

See Figure 1 and Figure 2 for a graphical summary of methodological quality for the 16 included studies, based on the six risk of bias domains.

Allocation-All trials were described as randomised. Using the Cochrane criteria which rate the adequacy of the random allocation concealment, most of the trials were rated as "unclear" or moderate risk of bias except Endo 1995, Shinkai 2004 and Yamashita 1995, in which risk of bias was rated as low.

Blinding-The outcome assessment was blind to treatment allocation in most of the studies except Shinkai 2004, in which the adequacy of the blinding was rated as "unclear" or moderate risk of bias, and Lee $2002 \mathrm{~b}$ where the design was 'open label'.

Incomplete outcome data-Five studies were incomplete in outcome reporting (Annseau 1994;Guelfi 1998a;Tignol 1998; Van Amerongen 2002; Yang 2003).

Selective reporting - The study protocol was not available for all studies. Two studies lacked reporting of adverse events (Yang 2003; Shinkai 2004), one did not report the number of participants experiencing at least some side effects (Annseau 1994) and one (Tignol 1998) failed to report the MADRS scores indicated in the methods section of the published trial report. One study did not report the number of participants who dropped out 
from the trial due to any reason (Leinonen 1997) and other did not report the number of participants who dropped out from the trial due to side effects (Annseau 1989a).

Standard deviations were not reported In five studies (Annseau 1991c; Guelfi 1998a; Tignol 1998; Sechter 2000; Van Amerongen 2002). Two studies were rated as "unclear" due to insufficient information (Lee 2002b; Lopez-Ibor 2004).

Other potential sources of bias—Except for Shinkai 2004, all the studies were sponsored by a pharmaceutical company marketing milnacipran.

\section{Effects of interventions}

The results are reported comparison by comparison (TCAs, Heterocyclics, SSRIs and newer antidepressants) and the forest plots are organised according to the relevance of outcomes, as reported in the review protocol. Some significant differences in efficacy, acceptability and tolerability were found and details are listed below.

1. Milnacipran versus TCAs-Efficacy outcomes were obtained from 7 studies $(n=820)$ ([dichotomous outcomes] acute phase: 4 studies, $n=537$, early phase: 6 studies, $n=802$; [continuous outcomes] acute phase: 7 studies, $n=820$, early phase: 6 studies, $n=765$ ). Acceptability outcomes were obtained from 7 studies $(\mathrm{n}=902)$ (due to any reason: 6 studies $(\mathrm{n}=795)$, due to inefficacy: 7 studies $(\mathrm{n}=902)$, due to side effects: 6 studies $(\mathrm{n}=756)$ ). Tolerability outcomes were obtained from 6 studies $(n=795)$.

\section{A. Milnacipran versus Imipramine 1.PRIMARY OUTCOME}

a) Acute phase treatment (6 to 12 weeks): There was no evidence that milnacipran was more efficacious than imipramine (OR1.05, 95\%CI: 0.71 to 1.54) (see Analysis 1.1,Figure $3)$.

b) Early phase treatment (1 to 4 weeks): No substantial effect was found with milnacipran compared to imipramine (OR1.11, 95\%CI: 0.73 to 1.69) (see Analysis 2.1,Figure 4).

c) Follow-up phase treatment (16 to 24 weeks): No data available.

\section{SECONDARY OUTCOMES (only figures for substantial differences were reported in the text)}

a) Acute phase treatment (6 to 12 weeks): No substantial effect was found with milnacipran compared imipramine (see Analysis 4.1).

b) Early phase treatment (1 to 4 weeks): No substantial effect was found with milnacipran compared imipramine (see Analysis 5.1).

c) Follow-up phase treatment (16 to 24 weeks): No data available.

a) Acute phase treatment (6 to 12 weeks): No substantial effect was found with milnacipran compared to imipramine (see Analysis 7.1). 
b) Early phase treatment (1 to 4 weeks): No substantial effect was found with milnacipran compared to imipramine (see Analysis 8.1).

c) Follow-up phase treatment (16 to 24 weeks): No data available.

2-3 to -5. EFFICACY-Social adjustment, social functioning, health-related quality of life, costs to health care services: No data available.

a) Due to any cause: There was no evidence that milnacipran was associated with a higher or lower rate of drop out due to any cause compared to imipramine (see Analysis 9.1).

b) Due to inefficacy: There was no evidence that milnacipran was associated with a higher or lower rate of drop out due to inefficacy compared to imipramine (see Analysis 10.1).

c) Due to adverse events: There was no evidence that milnacipran was associated with a higher or lower rate of drop out due to adverse events compared to imipramine (see Analysis 11.1).

a) Total number of patients experiencing at least one adverse event: There was evidence that milnacipran was associated with a lower rate of patients experiencing adverse events than imipramine (OR 0.43, 95\% CI 0.28 to 0.66 ) (see Analysis 12.1, Figure 5).

1. sleepiness/drowsiness

There was no evidence that milnacipran was associated with a higher or lower rate of participants experiencing sleepiness/drowsiness than imipramine (see Analysis 13.1).

2. insomnia

There was no evidence that milnacipran was associated with a higher or lower rate of participants experiencing insomnia than imipramine (see Analysis 14.1).

3. dry mouth

There was evidence that milnacipran was associated with a lower rate of participants experiencing dry mouth than imipramine (OR $0.57,95 \%$ CI 0.37 to 0.86) (see Analysis 15.1).

4. constipation

There was evidence that milnacipran was associated with a lower rate of participants experiencing constipation than imipramine (OR $0.64,95 \% \mathrm{CI} 0.41$ to 0.98) (see Analysis 16.1).

5. urination problems

There was no evidence that milnacipran was associated with a higher or lower rate of participants experiencing urination problems than imipramine (see Analysis 17.1).

6. hypotension 
There was no evidence that milnacipran was associated with a lower rate of participants experiencing hypotension than imipramine (see Analysis 18.1).

7. agitation/anxiety

There was no evidence that milnacipran was associated with a higher or lower rate of participants experiencing agitation/anxiety than imipramine (see Analysis 19.1).

8. suicide wishes/gestures/attempts

No data available.

9. completed suicide

No data available.

10. vomiting/nausea

There was evidence that milnacipran was associated with a higher rate of participants experiencing vomiting/nausea than imipramine (OR 2.31, 95\%CI 1.13 to 4.72) (see Analysis 22.1).

11. diarrhoea

There was no evidence that milnacipran was associated with a higher or lower rate of participants experiencing diarrhoea than imipramine (see Analysis 23.1).

B. Milnacipran versus Clomipramine: Only Leinonen 1997 provided the data.

\section{PRIMARY OUTCOME}

a) Acute phase treatment (6 to 12 weeks): There was evidence that clomipramine was more efficacious than milnacipran (OR0.45, 95\%CI: 0.21 to 0.98) (see Analysis 1.1,Figure 3).

b) Early phase treatment (1 to 4 weeks): No substantial effect was found with milnacipran compared to clomipramine (OR0.46, 95\%CI: 0.17 to 1.24) (see Analysis 2.1,Figure 4).

c) Follow-up phase treatment (16 to 24 weeks): No substantial effect was found with milnacipran compared to clomipramine (OR0.72, 95\%CI: 0.33 to 1.55) (see Analysis 3.1,Figure 6).

\section{SECONDARY OUTCOMES (only figures for substantial differences were reported in the text)}

a) Acute phase treatment (6 to 12 weeks): No substantial effect was found with milnacipran compared to clomipramine (see Analysis 4.1).

b) Early phase treatment (1 to 4 weeks): No substantial effect was found with milnacipran compared to clomipramine (see Analysis 5.1).

c) Follow-up phase treatment (16 to 24 weeks): No substantial effect was found with milnacipran compared to clomipramine (see Analysis 6.1). 
a) Acute phase treatment (6 to 12 weeks): There was evidence that clomipramine was more efficacious than milnacipran (SMD 0.44, 95\%C:I 0.03 to 0.85) (see Analysis 7.1).

b) Early phase treatment (1 to 4 weeks): No substantial effect was found with milnacipran compared to clomipramine (see Analysis 8.1).

c) Follow-up phase treatment (16 to 24 weeks): No data available.

2-3 to -5. EFFICACY-Social adjustment, social functioning, health-related quality of life, costs to health care services: No data available.

a) Due to any cause: There was no evidence that milnacipran was associated with a higher or lower rate of drop out due to any cause compared to clomipramine (see Analysis 9.1).

b) Due to inefficacy: There was no evidence that milnacipran was associated with a higher or lower rate of drop out due to inefficacy compared to clomipramine (see Analysis 10.1).

c) Due to adverse events: There was no evidence that milnacipran was associated with a higher or lower rate of drop out due to adverse events compared to clomipramine (see Analysis 11.1).

a) Total number of patients experiencing at least one adverse event: No data available.

1. sleepiness/drowsiness

There was no evidence that milnacipran was associated with a higher or lower rate of participants experiencing sleepiness/drowsiness than clomipramine (see Analysis 13.1).

2. insomnia

There was evidence that milnacipran was associated with a higher rate of participants experiencing insomnia than clomipramine (OR 5.55, 95\% CI 1.14 to 27.04) (see Analysis 14.1).

3. dry mouth

There was evidence that milnacipran was associated with a lower rate of participants experiencing dry mouth than clomipramine (OR 0.45, 95\%CI 0.21 to 0.97) (see Analysis 15.1).

4. constipation

No data available.

5. urination problems

No data available.

6. hypotension

There was no evidence that milnacipran was associated with a higher or lower rate of participants experiencing hypotension than clomipramine (see Analysis 18.1). 
7. agitation/anxiety

No data available.

8. suicide wishes/gestures/attempts

There was no evidence that milnacipran was associated with a higher or lower rate of participants experiencing suicide wishes/gestures/attempts than clomipramine (see Analysis 20.1).

9. completed suicide

No data available.

10. vomiting/nausea

There was no evidence that milnacipran was associated with a higher or lower rate of participants experiencing vomiting/nausea than clomipramine (see Analysis 22.1).

11. diarrhoea

There was no evidence that milnacipran was associated with a higher or lower rate of participants experiencing diarrhoea than clomipramine (see Analysis 23.1).

\section{Milnacipran versus Amitriptyline}

\section{PRIMARY OUTCOME}

a) Acute phase treatment (6 to 12 weeks): No data available.

b) Early phase treatment (1 to 4 weeks): No substantial effect was found with milnacipran compared to amitriptyline (OR 0.62, 95\%CI: 0.35 to 1.08) (see Analysis 2.1,Figure 4).

c) Follow-up phase treatment (16 to 24 weeks): No data available.

\section{SECONDARY OUTCOMES (only figures for substantial differences were reported in the text)}

a) Acute phase treatment (6 to 12 weeks): No data available.

b) Early phase treatment (1 to 4 weeks): No substantial effect was found with milnacipran compared to amitriptyline (see Analysis 5.1).

c) Follow-up phase treatment (16 to 24 weeks): No data available.

a) Acute phase treatment (6 to 12 weeks): No substantial effect was found with milnacipran compared to amitriptyline (see Analysis 7.1).

b) Early phase treatment (1 to 4 weeks): No substantial effect was found with milnacipran compared to amitriptyline (see Analysis 8.1).

c) Follow-up phase treatment (16 to 24 weeks): No data available. 
2-3 to -5. EFFICACY-Social adjustment, social functioning, health-related quality of life, costs to health care services: No data available.

a) Due to any cause: There was no evidence that milnacipran was associated with smaller or larger rate of drop out rate due to any cause compared to amitriptyline (see Analysis 9.1).

b) Due to inefficacy: There was no evidence that milnacipran was associated with smaller or larger rate of drop out rate due to inefficacy compared to amitriptyline (see Analysis 10.1).

c) Due to adverse events: There was no evidence that milnacipran was associated with smaller or larger rate of drop out rate due to adverse events compared to amitriptyline (see Analysis 11.1).

a) Total number of patients experiencing at least one adverse event: There was evidence that milnacipran was associated with smaller rate of patients experiencing adverse events than amitriptyline (OR 0.23 , 95\% CI 0.13 to 0.40 ) (see Analysis 12.1, Figure 5).

1. sleepiness/drowsiness

There was evidence that milnacipran was associated with a lower rate of participants experiencing sleepiness/drowsiness than amitriptyline (OR 0.07, 95\% CI 0.02 to 0.22 ) (see Analysis 13.1).

2. insomnia

There was no evidence that milnacipran was associated with a higher or lower rate of participants experiencing insomnia than amitriptyline (see Analysis 14.1).

3. dry mouth

There was evidence that milnacipran was associated with a lower rate of participants experiencing dry mouth than amitriptyline (OR $0.22,95 \%$ CI 0.12 to 0.39) (see Analysis 15.1).

4. constipation

There was no evidence that milnacipran was associated with a higher or lower rate of participants experiencing insomnia than amitriptyline (see Analysis 16.1).

5. urination problems

No data available.

6. hypotension

There was no evidence that milnacipran was associated with a higher or lower rate of participants experiencing hypotension than amitriptyline (see Analysis 18.1).

7. agitation/anxiety

There was no evidence that milnacipran was associated with a higher or lower rate of participants experiencing agitation/anxiety than amitriptyline (see Analysis 19.1).

8. suicide wishes/gestures/attempts 
No data available.

9. completed suicide

No data available.

10. vomiting/nausea

There was no evidence that milnacipran was associated with a higher or lower rate of participants experiencing vomiting/nausea than amitriptyline (see Analysis 22.1).

11. diarrhoea

There was no evidence that milnacipran was associated with a higher or lower rate of participants experiencing diarrhoea than amitriptyline (see Analysis 23.1).

2. Milnacipran versus Heterocyclics-Only Endo $1995(\mathrm{n}=179)$ that compared milnacipran with mianserin provided efficacy, acceptability and tolerability outcomes.

\section{A. Milnacipran versus Mianserin}

\section{PRIMARY OUTCOME}

a) Acute phase treatment (6 to 12 weeks): No data available.

b) Early phase treatment (1 to 4 weeks): No substantial effect was found with milnacipran compared to mianserin (OR1.10, 95\%CI: 0.54 to 2.23) (see Analysis 2.3, Figure 7).

c) Follow-up phase treatment (16 to 24 weeks): No data available.

\section{SECONDARY OUTCOMES}

a) Acute phase treatment (6 to 12 weeks): No data available.

b) Early phase treatment (1 to 4 weeks): No substantial effect was found with milnacipran compared to mianserin (see Analysis 5.3).

c) Follow-up phase treatment (16 to 24 weeks): No data available.

a) Acute phase treatment (6 to 12 weeks): No substantial effect was found with milnacipran compared to mianserin (see Analysis 7.3).

b) Early phase treatment (1 to 4 weeks): No substantial effect was found with milnacipran compared to mianserin (see Analysis 8.3).

c) Follow-up phase treatment (16 to 24 weeks): No data available.

2-3 to -5. EFFICACY-Social adjustment, social functioning, health-related quality of life, costs to health care services: No data available.

a) Due to any cause: There was no evidence that milnacipran was associated with higher or lower rate of drop out rate due to any cause compared to mianserin (see Analysis 9.3). 
b) Due to inefficacy: There was no evidence that milnacipran was associated with higher or lower rate of drop out rate due to inefficacy compared to mianserin (see Analysis 10.3).

c) Due to adverse events: There was no evidence that milnacipran was associated with higher or lower rate of drop out due to adverse events compared to mianserin (see Analysis 11.3).

a) Total number of patients experiencing at least one adverse event: There was no evidence that milnacipran was associated with higher or lower rate of patients experiencing adverse events than mianserin (see Analysis 12.3).

1. sleepiness/drowsiness

There was evidence that milnacipran was associated with a lower rate of participants experiencing sleepiness/drowsiness than mianserin (OR $0.21,95 \% \mathrm{CI}$ 0.08 to 0.58 ) (see Analysis 13.3)

2. insomnia

There was no evidence that milnacipran was associated with a higher or lower rate of participants experiencing insomnia than mianserin (see Analysis 14.3).

3. dry mouth

There was no evidence that milnacipran was associated with a higher or lower rate of participants experiencing dry mouth than mianserin (see Analysis 15.3).

4. constipation

There was no evidence that milnacipran was associated with a higher or lower rate of participants experiencing insomnia than mianserin (see Analysis 16.3).

5. urination problems

There was no evidence that milnacipran was associated with a higher or lower rate of participants experiencing insomnia than mianserin (see Analysis 17.3).

6. hypotension

There was no evidence that milnacipran was associated with a higher or lower rate of participants experiencing hypotension than mianserin (see Analysis 18.3).

7. agitation/anxiety

There was no evidence that milnacipran was associated with a higher or lower rate of participants experiencing agitation/anxiety than mianserin (see Analysis 19.3).

8. suicide wishes/gestures/attempts

No data available.

9. completed suicide

No data available.

10. vomiting/nausea 
There was no evidence that milnacipran was associated with a higher or lower rate of participants experiencing vomiting/nausea than mianserin (see Analysis 22.3).

11. diarrhoea

No data reported.

3. Milnacipran versus SSRIs-Efficacy and acceptability outcomes were obtained from two studies comparing milnacipran with fluvoxamine (Annseau 1991c;Clerc 2001), three with fluoxetine (Annseau 1994; Guelfi 1998a;Lee 2002b), two with paroxetine (Sechter 2000; Shinkai 2004), and the remaining one with sertraline (Yang 2003). Outcome concerning tolerability were extractable from two studies comparing milnacipran with fluvoxamine (Annseau 1991c; Clerc 2001), two with fluoxetine (Guelfi 1998a; Lee 2002b), one with paroxetine (Sechter 2000) and none with sertraline.

\section{A. Milnacipran versus Fluvoxamine 1.PRIMARY OUTCOME}

a) Acute phase treatment (6 to 12 weeks): There was no evidence that milnacipran was more efficacious than fluvoxamine (OR1.76, 95\%CI: 0.81 to 3.83) (see Analysis 1.2, Figure 8).

b) Early phase treatment (1 to 4 weeks): No substantial effect was found with milnacipran compared to fluvoxamine (OR1.54, 95\%CI: 0.87 to 2.72) (see Analysis 2.2, Figure 9).

c) Follow-up phase treatment (16 to 24 weeks): No data available.

\section{SECONDARY OUTCOMES (only figures for substantial differences were reported in the text)}

a) Acute phase treatment (6 to 12 weeks): No substantial effect was found with milnacipran compared to fluvoxamine (see Analysis 4.2).

b) Early phase treatment (1 to 4 weeks): No substantial effect was found with milnacipran compared to fluvoxamine (see Analysis 5.2).

c) Follow-up phase treatment (16 to 24 weeks): No data available.

a) Acute phase treatment (6 to 12 weeks): No substantial effect was found with milnacipran compared to fluvoxamine (see Analysis 7.2).

b) Early phase treatment (1 to 4 weeks): No substantial effect was found with milnacipran compared to fluvoxamine (see Analysis 8.2).

c) Follow-up phase treatment (16 to 24 weeks): No data available.

2-3 to -5. EFFICACY-Social adjustment, social functioning, health-related quality of life, costs to health care services: No data available. 
a) Due to any cause: There was no evidence that milnacipran was associated with higher or lower rate of drop out due to any cause compared to fluvoxamine (see Analysis 9.2).

b) Due to inefficacy: There was no evidence that milnacipran was associated with higher or lower rate of drop out due to inefficacy compared to fluvoxamine (see Analysis 10.2).

c) Due to adverse events: There was no evidence that milnacipran was associated with higher or lower rate of drop out due to adverse events compared to fluvoxamine (see Analysis 11.2).

a) Total number of patients experiencing at least one adverse event: There was evidence that milnacipran was associated with lower rate of patients experiencing adverse events than fluvoxamine (OR $0.51,95 \%$ CI 0.28 to 0.94 ) (see Analysis 12.2).

1. sleepiness/drowsiness

There was no evidence that milnacipran was associated with a higher or lower rate of participants experiencing sleepiness/drowsiness than fluvoxamine (see Analysis 13.2).

2. insomnia

There was no evidence that milnacipran was associated with a higher or lower rate of participants experiencing insomnia than fluvoxamine (see Analysis 14.2).

3. dry mouth

There was no evidence that milnacipran was associated with a higher or lower rate of participants experiencing dry mouth than fluvoxamine (see Analysis 15.2).

4. constipation

There was no evidence that milnacipran was associated with a higher or lower rate of participants experiencing constipation than fluvoxamine (see Analysis 16.2).

5. urination problems

There was no evidence that milnacipran was associated with a higher or lower rate of participants experiencing urination problems than fluvoxamine (see Analysis 17.2).

6. hypotension

There was no evidence that milnacipran was associated with a higher or lower rate of participants experiencing hypotension than fluvoxamine (see Analysis 18.2).

7. agitation/anxiety

There was no evidence that milnacipran was associated with a higher or lower rate of participants experiencing agitation/anxiety than fluvoxamine (see Analysis 19.2).

8. suicide wishes/gestures/attempts

No data available. 
9. completed suicide

No data available.

10. vomiting/nausea

There was evidence that milnacipran was associated with a lower rate of participants experiencing vomiting/nausea than fluvoxamine (OR 0.51, 95\%CI 0.28 to 0.94 )(see Analysis 22.2).

11. diarrhoea

There was no evidence that milnacipran was associated with a higher or lower rate of participants experiencing diarrhoea than fluvoxamine (see Analysis 23.2).

\section{B. Milnacipran versus Fluoxetine}

\section{PRIMARY OUTCOME}

a) Acute phase treatment (6 to 12 weeks): There was no evidence that milnacipran was more efficacious than fluoxetine (OR0.93, 95\%CI: 0.55 to 1.58) (see Analysis 1.2, Figure 8).

b) Early phase treatment (1 to 4 weeks): No substantial effect was found with milnacipran compared to fluoxetine (OR1.49, 95\%CI: 0.93 to 2.37) (see Analysis 2.2,Figure 9).

c) Follow-up phase treatment (16 to 24 weeks): No data available.

\section{SECONDARY OUTCOMES (only figures for substantial differences were reported in the text)}

a) Acute phase treatment (6 to 12 weeks): No substantial effect was found with milnacipran compared to fluoxetine (see Analysis 4.2).

b) Early phase treatment (1 to 4 weeks): No substantial effect was found with milnacipran compared to fluoxetine (see Analysis 5.2).

c) Follow-up phase treatment (16 to 24 weeks): No data available.

a) Acute phase treatment (6 to 12 weeks): No substantial effect was found with milnacipran compared to fluoxetine (see Analysis 7.2).

b) Early phase treatment (1 to 4 weeks): No substantial effect was found with milnacipran compared to fluoxetine (see Analysis 8.2).

c) Follow-up phase treatment (16 to 24 weeks): No data available.

2-3 to -5. EFFICACY-Social adjustment, social functioning, health-related quality of life, costs to health care services: No data available.

a) Due to any cause: There was no evidence that milnacipran was associated with higher or lower rate of drop out due to any cause compared to fluoxetine (see Analysis 9.2). 
b) Due to inefficacy: There was no evidence that milnacipran was associated with higher or lower rate of drop out due to inefficacy compared to fluoxetine (see Analysis 10.2).

c) Due to adverse events: There was no evidence that milnacipran was associated with higher or lower rate of drop out due to adverse events compared to fluoxetine (see Analysis 11.2).

a) Total number of patients experiencing at least one adverse event: There was no evidence that milnacipran was associated with higher or lower rate of patients experiencing adverse events than fluoxetine (see Analysis 12.2).

1. sleepiness/drowsiness

There was no evidence that milnacipran was associated with a higher or lower rate of participants experiencing sleepiness/drowsiness than fluoxetine (see Analysis 13.2).

2. insomnia

There was evidence that milnacipran was associated with a lower rate of participants experiencing insomnia than fluoxetine (OR $0.41,95 \% \mathrm{CI}$ : 0.20 to 0.87 ) (see Analysis 14.2).

3. dry mouth

There was no evidence that milnacipran was associated with a higher or lower rate of participants experiencing dry mouth than fluoxetine (see Analysis 15.2).

4. constipation

There was no evidence that milnacipran was associated with a higher or lower rate of participants experiencing constipation than fluoxetine (see Analysis 16.2).

5. urination problems

There was no evidence that milnacipran was associated with a higher or lower rate of participants experiencing urination problems than fluoxetine (see Analysis 17.2).

6. hypotension

There was no evidence that milnacipran was associated with a higher or lower rate of participants experiencing hypotension than fluoxetine (see Analysis 18.2).

7. agitation/anxiety

There was no evidence that milnacipran was associated with a higher or lower rate of participants experiencing agitation/anxiety than fluoxetine (see Analysis 19.2).

8. $\quad$ suicide wishes/gestures/attempts

There was no evidence that milnacipran was associated with a higher or lower rate of participants experiencing suicide wishes/gestures/attempts than fluoxetine (see Analysis 20.2).

9. completed suicide 
There was no evidence that milnacipran was associated with a higher or lower rate of participants experiencing completed suicide than fluoxetine (see Analysis 21.1).

10. vomiting/nausea

There was no evidence that milnacipran was associated with a higher or lower rate of participants experiencing vomiting/nausea than fluoxetine (see Analysis 22.2).

11. diarrhoea

There was no evidence that milnacipran was associated with a higher or lower rate of participants experiencing diarrhoea than fluoxetine (see Analysis 23.2).

\section{Milnacipran versus Paroxetine} 1.PRIMARY OUTCOME

a) Acute phase treatment (6 to 12 weeks): There was no evidence that milnacipran was more efficacious than paroxetine (OR0.93, 95\%CI: 0.59 to 1.47) (see Analysis 1.2,Figure 8).

b) Early phase treatment (1 to 4 weeks): No substantial effect was found with milnacipran compared to paroxetine (OR 0.99, 95\%CI: 0.61 to 1.60) (see Analysis 2.2,Figure 9).

c) Follow-up phase treatment (16 to 24 weeks): No data available.

\section{SECONDARY OUTCOMES (only figures for substantial differences were reported in the text)}

a) Acute phase treatment (6 to 12 weeks): No substantial effect was found with milnacipran compared to paroxetine (see Analysis 4.2).

b) Early phase treatment (1 to 4 weeks): No substantial effect was found with milnacipran compared to paroxetine (see Analysis 5.2).

c) Follow-up phase treatment (16 to 24 weeks): No data available.

a) Acute phase treatment (6 to 12 weeks): No substantial effect was found with milnacipran compared to paroxetine (see Analysis 7.2).

b) Early phase treatment (1 to 4 weeks): No substantial effect was found with milnacipran compared to paroxetine (see Analysis 8.2).

c) Follow-up phase treatment (16 to 24 weeks): No data available.

2-3 to -5. EFFICACY-Social adjustment, social functioning, health-related quality of life, costs to health care services: No data available.

a) Due to any cause: There was no evidence that milnacipran was associated with a higher or lower rate of drop out due to any cause compared to paroxetine (see Analysis 9.2).

b) Due to inefficacy: There was no evidence that milnacipran was associated with a higher or lower rate of drop out due to inefficacy compared to paroxetine (see Analysis 10.2). 
c) Due to adverse events: There was no evidence that milnacipran was associated with a higher or lower rate of drop out due to adverse events compared to paroxetine (see Analysis 11.2).

a) Total number of patients experiencing at least one adverse event: There was no evidence that milnacipran was associated with a higher or lower rate of patients experiencing adverse events than paroxetine (see Analysis 12.2).

1. sleepiness/drowsiness

There was no evidence that milnacipran was associated with a higher or lower rate of participants experiencing sleepiness/drowsiness than paroxetine (see Analysis 13.2).

2. insomnia

There was no evidence that milnacipran was associated with a higher or lower rate of participants experiencing insomnia than paroxetine (see Analysis 14.2).

3. dry mouth

No data available.

4. constipation

No data available.

5. urination problems

There was no evidence that milnacipran was associated with a higher or lower rate of participants experiencing urination problem than paroxetine (see Analysis 17.2).

6. hypotension

No data available.

7. agitation/anxiety

There was no evidence that milnacipran was associated with a higher or lower rate of participants experiencing agitation/anxiety than paroxetine (see Analysis 19.2).

8. suicide wishes/gestures/attempts

No data available.

9. completed suicide

No data available.

10. vomiting/nausea

There was evidence that milnacipran was associated with a higher or lower rate of participants experiencing vomiting/nausea than paroxetine (see Analysis 22.2).

11. diarrhoea

There was no evidence that milnacipran was associated with a higher or lower rate of participants experiencing diarrhoea than paroxetine (see Analysis 23.2). 


\section{Milnacipran versus Sertraline}

\section{PRIMARY OUTCOME}

a) Acute phase treatment (6 to 12 weeks): There was no evidence that milnacipran was more efficacious than sertraline (OR 3.83, 95\%CI: 0.90 to 16.26) (see Analysis 1.2,Figure 8).

b) Early phase treatment (1 to 4 weeks): No data available.

c) Follow-up phase treatment (16 to 24 weeks): No data available.

\section{SECONDARY OUTCOMES (only figures for substantial differences were reported in the text)}

a) Acute phase treatment (6 to 12 weeks): Not estimable.

b) Early phase treatment (1 to 4 weeks): No data available.

c) Follow-up phase treatment (16 to 24 weeks): No data available.

a) Acute phase treatment (6 to 12 weeks): No substantial effect was found with milnacipran compared to sertraline (see Analysis 7.2).

b) Early phase treatment (1 to 4 weeks): No data available.

c) Follow-up phase treatment (16 to 24 weeks): No data available.

2-3 to -5. EFFICACY-Social adjustment, social functioning, health-related quality of life, costs to health care services: No data available.

a) Due to any cause: There was no evidence that milnacipran was associated with a higher or lower rate of drop out due to any cause compared to sertraline (see Analysis 9.2).

b) Due to inefficacy: No data available.

c) Due to adverse events: No data available.

a) Total number of patients experiencing at least one adverse event: No data available.

1. sleepiness/drowsiness

No data available.

2. insomnia

No data available.

3. dry mouth

No data available.

4. constipation

No data available. 
5. urination problems

No data available.

6. hypotension

No data available.

7. agitation/anxiety

No data available.

8. suicide wishes/gestures/attempts

No data available.

9. completed suicide

No data available.

10. vomiting/nausea

No data available.

11. diarrhoea

No data available.

\section{Subgroup and sensitivity analysis \\ Subgroup analysis}

1. Milnacipran dosing: When we limited to participants treated with high dose milnacipran, no difference was found for response at early phase compared with TCAs (see Analysis 24.1). Response at acute phase was not analysed because only Leinonen 1997 provided relevant data. In terms of SSRIs, all studies were within the therapeutic range with the exception of Annseau 1991c, in which a higher dose was used. Due to the small number of trials without the therapeutic range, it was not considered meaningful to carry out this preplanned subgroup analysis.

Participants treated with low dose ( $<100 \mathrm{mg} /$ day) milnacipran were compared with TCAs (Yamashita 1995), with heterocyclics (Endo 1995) and with SSRIs (Shinkai 2004). Due to the small number of trials without the therapeutic range for each comparison, it was not considered meaningful to carry out this pre-planned subgroup analysis.

Four studies (Yamashita 1995, Endo 1995, Leinonen 1997, Tignol 1998) involved a flexible-dose scheduling design. When we limited to studies involving a flexible-dose scheduling design, no difference was found for response compared with TCAs (see Analysis 25.1,Analysis 26.1).

2. Comparator dosing: All comparator doses were within the therapeutic range, with the exception of Clerc 2001, which used a higher dose, and Yamashita 1995, which used a lower dose. Due to the small number of trials without the therapeutic range, it was not considered meaningful to carry out this pre-planned subgroup analysis. 
3. Depression severity: All studies reported a mean baseline score corresponding to moderate major depression, with the exception of Guelfi 1998a where the mean baseline score corresponded to a severe major depression. Therefore, it was not meaningful to carry out this pre-planned subgroup analysis.

4. Treatment settings: Among subgroups by the study settings, we did not find difference for response between milnacipran and TCAs or SSRIs based on seven studies for inpatients (comparing TCAs: Annseau 1989a;Annseau 1989c; Van Amerongen 2002; Lopez-Ibor 2004, comparing SSRIs: Annseau 1991c; Guelfi 1998a; Shinkai 2004) and four studies for outpatients (comparing SSRIs only:Annseau 1994;Sechter 2000; Lee 2002b; Yang 2003). Among subgroups by the study settings, we did not find difference for response in each settings (see Analysis 27.1, Analysis 28.1, Analysis 29.1, Analysis 29.2, Analysis 30.1).

5. Elderly patients: As only one study specifically recruited elderly patients (Tignol 1998), it was not meaningful to carry out this pre-planned subgroup analysis.

\section{Sensitivity analysis}

\section{Excluding trials with unclear concealment of random allocation and/or unclear}

double blinding: Although technically possible to carry out these sensitivity analyses, they were not performed, because they would not have contributed useful information due to the small number of studies (only three trials) reporting clear details on concealment of random allocation (Endo 1995, Yamashita 1995, Shinkai 2004).

2. Excluding trials whose dropout rate was greater than $20 \%$ : Referring to TCAs, a dropout rate greater than $20 \%$ was found for four studies comparing milnacipran with imipramine (Yamashita 1995, Tignol 1998, Van Amerongen 2002, Lopez-Ibor 2004) and one with amitriptyline (Annseau 1989a). In terms of heterocyclics, the only study (Endo 1995) comparing milnacipran with mianserin reported a dropout rate greater than $20 \%$. Among SSRIs, a dropout rate greater than $20 \%$ was found for two studies comparing milnacipran with fluoxetine (Guelfi 1998a, Lee 2002b), one with fluvoxamine (Clerc 2001), one with paroxetine (Sechter 2000) and one with sertraline (Yang 2003). Therefore, these preplanned sensitivity analyses were not carried out because there were insufficient trials to allow meaningful formal assessment.

3. Performing the worst and best-case scenario analysis: Results from these sensitivity analyses did not materially change the main findings (full details available on request from authors)

\section{Excluding trials for which the imputation methods were used}

a) Imputed response rate: Excluding trials for which the response rate had to be calculated based on the imputation method, results for all comparisons did not materially change the main findings.

b) Borrowed SDs: Excluding trials for which the SD had to be borrowed from other trials, results from these sensitivity analyses did not materially change the main findings. 


\section{Examination of "wish bias" and exclusion of studies funded by the pharmaceutical} company marketing milnacipran: These pre-planned sensitivity analyses were not carried out because there were insufficient trials run by manufacturers other than the pharmaceutical company marketing milnacipran to allow meaningful formal assessment. All the studies were sponsored by a pharmaceutical company marketing milnacipran except for Shinkai 2004.

Funnel plot analysis-There was no evidence of publication bias or other small study effects based on visual inspections of the funnel-plots with regard to the outcome variables.

\section{DISCUSSION}

\section{Summary of main results}

A total of 16 randomised controlled trials $(n=2277)$ were included in this review. Milnacipran does not seem to provide a significant advantage in efficacy over other antidepressive agents for the acute phase treatment of major depression. However, the data from one trial suggest that milnacipran may be inferior in terms of response compared to clomipramine (OR0.45, 95\%CI: 0.21 to 0.98). Further, compared with TCAs, intervention groups including patients taking milnacipran were associated with fewer patients leaving the trial early due to adverse events as compared to patients taking TCAs (OR 0.55; 95\% CI 0.35 to 0.85 ) (Analysis 11.1). There was also small amount of evidence that patients taking milnacipran experienced fewer adverse events of sleepiness/drowsiness, dry mouth or constipation, as compared with those taking TCAs. The included studies did not report on all the outcomes that were pre-specified in the protocol of this review. Outcomes of clear relevance to patients and clinicians, in particular, patients' and their carers' attitudes to treatment, their ability to return to work and resume normal social functioning, were not reported in the included studies. Also, only a small number of trials per comparison were found for most of the antidepressants. This limits the power of the review to detect moderate but clinically meaningful differences between the antidepressive agents.

\section{Overall completeness and applicability of evidence}

It has long been argued that placebo controlled trials are required to adequately demonstrate the efficacy of novel antidepressant drugs (Kupfer 2002), however, in the present review we focused only on the comparison between milnacipran and other active treatments for two reasons. First, in this review we focused on the following important clinical matter: "When an milnacipran is to be prescribed, would it constitute the better choice?"

To answer this question within a clinically sound perspective, we included studies with active treatment comparisons. Second, placebo-controlled studies are different from active comparator trials in terms of design, conduct and population, and furthermore it has been shown that placebo response in published trials of antidepressant drug for major depressive disorder is highly variable and often substantial (Walsh 2002). Retrieved randomised evidence compared milnacipran with a small selection of possible comparator antidepressants and no trials comparing milnacipran with escitalopram or citalopram (amongst SSRIs), or with venlafaxine, duloxetine, mirtazapine, bupropion, reboxetine or 
hypericum (amongst the newer antidepressive agents), or with some of the first generation antidepressants (such as MAOIs) were found. Although the search was comprehensive and thorough, it is still possible that there are unpublished studies that have not been identified but the small number of trials identified per comparison hinders the detection of any publication bias.

As in all systematic reviews and meta-analyses, in the present study the main concern is about assessing the studies which were identified. The more information that is pooled together, the more precise and accurate is the estimate (Higgins 2005). We are realistically aware that a possibly significant piece of information has not been published and thus is not contributing to the true treatment estimate we were seeking. Although we did our very best to retrieve as many data as possible, through asking pharmaceutical companies and study authors to supply all available information, we can assume that data from some trials are still lacking, most of which are likely to be studies with negative findings. We are also aware of the possibility that a number of further randomised controlled trials comparing milnacipran with other antidepressant drugs are currently being conducted and these will be included in future updates of the review.

\section{Potential biases in the review process}

Some possible limitations of this review should be noted. Firstly, we had to impute the response and remission rates, our primary outcome, for most of the included trials. However, we consider that this is hardly rare, since incomplete reporting of outcome (i.e. an outcome reporting bias) is common within published articles of randomised trials (Chan 2004, Chan 2005). Further, imputation of response and remission rates by a validated statistical method (Furukawa 2006) in our review should minimize those biases. Nevertheless, we regret that we were unable to do a sensitivity analysis excluding trials with imputed response rates. As we update this review and assemble more trials involving milnacipran, we hope to conduct such a sensitivity analysis and be able to examine if our conclusions are robust.

Secondly, high dropout rates reduce the reliability of the assessment of other outcomes. Further, by making multiple comparisons we might have committed a type 1 error, that is, identifying and reporting a spurious association. Thirdly, all but one of the included trials had been funded by the drug company marketing milnacipran. There is nothing inherently wrong or biasing in this but, in view of the overwhelming evidence that sponsorship bias exists not only in psychiatry (Heres 2006) but also in medicine overall (Bekelman 2003), we should pay special attention that we may not inadvertently fall prey to such a bias.

Therefore, these associations should be made clear to let anyone judge the relevance of the current findings.

\section{Agreements and disagreements with other studies or reviews}

Venlafaxine, another dual serotonin-norepinephrine reuptake inhibitor, has been the first new generation antidepressant to be claimed to have differential effectiveness vis-a-vis the other antidepressants. The superiority of venlafaxine was first demonstrated in a drug company sponsored meta-analysis (Thase 2001), and subsequently confirmed in an independently conducted metaanalysis (Smith 2002). In addition, duloxetine, another SNRI, 
is also reported to be efficacious for the treatment of major depressive disorder and is well tolerated, safe and effective for the treatment of core depressive symptoms (Goldstein 2002, Cowen 2005,Frampton 2007). In keeping with these findings, milnacipran has been reported to be superior to SSRIs and equal to TCAs in two drug company sponsored meta-analyses (Puech 1997, Lopez-Ibor 1996). However, this superiority was not replicated in a subsequent independently-conducted meta-analysis (Papakostas 2007a). Our current review, which has included two additional trials involving SSRIs (Shinkai 2004, Yang 2003), and seven TCAs trials (Tignol 1998, Van Amerongen 2002, Lopez-Ibor 2004, Leinonen 1997,Annseau 1989a, Annseau 1989c, Yamashita 1995) and one heterocyclic trial (Endo 1995) since Papakostas 2007a, confirms its findings.

The methodological limitation of standard systematic reviews is that they can rely only on evidence from direct comparisons. However, given the wide spectrum of available comparisons for the treatment of major depression, the use of the methodology of multiple treatments meta-analysis (MTM, also known as network meta-analysis) may help overcome this limitation (Lumley 2002;Lu 2004: Lu 2006; Salanti 2008). MTM is a statistical method that enables to integrate data from direct comparisons (when treatments are compared within a randomised trial) and indirect comparisons (when treatments are compared between trials by combining results on how effective they are against a common comparator treatment) involving diverse regimens, and to assess the strength and consistency of the evidence.

MTM has already been used in other fields of medicine (Psaty 2003; Elliott 2007), and these comparisons may provide a clinically useful summary that can be used to guide treatment decisions. In the field of major depression, we have recently published a MTM including our data for milnacipran to compare both direct and indirect effects of 12 new-generation antidepressants (Cipriani 2009a). The corresponding OR with 95\%CI for efficacy (response rate) and acceptability (total dropout rate) are shown in Table 1. All of the confidence intervals overlap widely between MTM and direct comparisons, mainly because the confidence intervals of the direct comparisons are wide, generally indicating that the network of evidence is consistent. When the relative ratio of ORs was smaller than 0.59 (vs fluvoxamine and vs sertraline for response), the ORs of the MTM were revealed to be more conservative (i.e. closer to the null result) than the direct comparisons. It is possible that including indirect evidence may have 'cancelled out' the potential biases such as sponsorship and publication biases. The value of MTMs are increasingly acknowledged (Santaguida 2005) along with their pitfalls (Ioannidis 2006). Further methodological work is needed to confirm the relevance and validity of the review.

\section{AUTHORS' CONCLUSIONS}

\section{Implications for practice}

The results of this review suggest that milnacipran is no more or less effective than other antidepressants in the acute phase treatment of major depression. There is also inadequate evidence to detect a substantial difference between milnacipran and other antidepressive agents in terms of acceptability and tolerability. However, there is some evidence in favour of milnacipran over TCAs in terms of dropouts due to adverse events and the rates of experiencing adverse events. 


\section{Implications for research}

More randomised controlled trials comparing milnacipran with other antidepressants are needed to generate more precise and accurate information about the drug. Also, randomised controlled trials comparing milnacipran with other comparator such as escitalopram, venlafaxine, duloxetine, mirtazapine, or hypericum are needed. Furthermore, future studies should focus to a greater extent on outcomes of clear relevance to patients and clinicians, in particular, patients' and their carers' attitudes to treatment, their ability to return to work and resume normal social functioning. Cost-effectiveness also need to be assessed.

\section{Acknowledgments}

This review is one publication of the Meta-Analyses of New Generation Antidepressants (MANGA) project in which a group of researchers within the Cochrane Collaboration Depression, Anxiety and Neurosis Group agreed to conduct a systematic review of all available evidence for 12 new generation antidepressants to inform clinical practice and mental health policies.

As of April 2009, we have completed an individual review for fluoxetine (Cipriani 2005), sertraline (Cipriani 2009b) and escitalopram (Cipriani 2009c), and published the protocols for fluvoxamine (Omori 2006), citalopram (Imperadore 2007), paroxetine (Cipriani 2007a), venlafaxine (Cipriani 2007b), duloxetine (Nose 2007) and mirtazapine (Watanabe 2006).

\section{CHARACTERISTICS OF STUDIES}

\section{Characteristics of included studies [ordered by study ID]}

Annseau 1989a

\begin{tabular}{|c|c|c|}
\hline Methods & \multicolumn{2}{|c|}{4 week randomised double blind study. } \\
\hline Participants & \multicolumn{2}{|c|}{$\begin{array}{l}\text { Diagnosis: Inpatients with RDC major depressive disorder } \\
\text { Male and Female. } \\
\text { Threshold of baseline severity: MADRS }>=25, \mathrm{CGI}<=4 \text {, Raskin Scale for } \\
\text { Depression>Covi Anxiety Scale } \\
\text { Total number of all allocated participants: } \mathrm{N}=146 \\
\text { Age: mean } 48.6 \text { (SD 10.8) y, range 20-70y. }\end{array}$} \\
\hline Interventions & \multicolumn{2}{|c|}{$\begin{array}{l}\text { Milnacipran 50/100mg: } \mathrm{N}=97 \text { (50mg: } \mathrm{N}=47,100 \mathrm{mg}: \mathrm{N}=48 \text { ) } \\
\text { Amitriptyline 150mg: } \mathrm{N}=49 \\
\text { Fixed dosing schedule }\end{array}$} \\
\hline Outcomes & \multicolumn{2}{|c|}{ Hamilton Depression Rating Scale-24 item, MADRS,CGI-I, CGI-S } \\
\hline Notes & \multicolumn{2}{|l|}{ Funding: by industry } \\
\hline \multicolumn{3}{|l|}{ Risk of bias } \\
\hline Item & Authors' judgement & Description \\
\hline Adequate sequence generation? & Yes & Quote: "randomly assigned". Probably done. \\
\hline Allocation concealment? & Unclear & Insufficient information. \\
\hline $\begin{array}{l}\text { Blinding? } \\
\text { All outcomes }\end{array}$ & Yes & Quote: "double-blind". Probably done. \\
\hline $\begin{array}{l}\text { Incomplete outcome data addressed? } \\
\text { All outcomes }\end{array}$ & Yes & No missing primary outcome data. \\
\hline Free of selective reporting? & No & $\begin{array}{l}\text { Did not provide number of participants who dropped } \\
\text { out during the study due to side effects }\end{array}$ \\
\hline
\end{tabular}




\begin{tabular}{|c|c|c|}
\hline Free of other bias? & Unclear & $\begin{array}{l}\text { Insufficient information to assess whether an important } \\
\text { risk of bias exists }\end{array}$ \\
\hline
\end{tabular}

\section{Annseau 1989c}

\begin{tabular}{|c|c|c|}
\hline Methods & \multicolumn{2}{|c|}{4 week randomised double blind study } \\
\hline Participants & \multicolumn{2}{|c|}{$\begin{array}{l}\text { Diagnosis: Inpatients with RDC major depressive disorder } \\
\text { Male and Female. } \\
\text { Threshold of baseline severity: MADRS }>=25, \mathrm{CGI}<=5 \text {, Raskin Scale for } \\
\text { Depression }>\text { Covi Anxiety Scale } \\
\text { Total number of all allocated participants: } \mathrm{N}=87 \\
\text { Age: mean } 49.6 \text { (SD 11.6) y, range 23-68y. }\end{array}$} \\
\hline Interventions & \multicolumn{2}{|c|}{$\begin{array}{l}\text { Milnacipran 200mg: } \mathrm{N}=44 \\
\text { Amitriptyline } 150 \mathrm{mg}: \mathrm{N}=43 \\
\text { Fixed dosing schedule. }\end{array}$} \\
\hline Outcomes & \multicolumn{2}{|c|}{ Hamilton Depression Rating Scale-24 item, MADRS,CGI-I, CGI-S } \\
\hline Notes & \multicolumn{2}{|l|}{ Funding: by industry } \\
\hline \multicolumn{3}{|l|}{ Risk of bias } \\
\hline Item & Authors' judgement & Description \\
\hline Adequate sequence generation? & Yes & Quote: "randomly assigned". Probably done. \\
\hline Allocation concealment? & Unclear & Insufficient information. \\
\hline $\begin{array}{l}\text { Blinding? } \\
\text { All outcomes }\end{array}$ & Yes & Quote: "double-blind" \\
\hline $\begin{array}{l}\text { Incomplete outcome data addressed? } \\
\text { All outcomes }\end{array}$ & Yes & No missing primary outcome data. \\
\hline Free of selective reporting? & Yes & $\begin{array}{l}\text { The study protocol is not available but it is clear that } \\
\text { the published reports include all expected outcomes, } \\
\text { including those that were pre-specified }\end{array}$ \\
\hline Free of other bias? & Unclear & $\begin{array}{l}\text { Insufficient information to assess whether an important } \\
\text { risk of bias exists }\end{array}$ \\
\hline
\end{tabular}

\section{Annseau 1991c}

\begin{tabular}{ll}
\hline Methods & 4 week randomised double blind study \\
\hline Participants & Diagnosis: Inpatients with RDC major depressive disorder \\
& Male and Female. \\
& Threshold of baseline severity: MADRS >=25, CGI<=5, Raskin Scale for \\
& Depression>Covi Anxiety Scale \\
& Total number of all allocated participants: N=127 \\
& Age: mean 43.7 (SD 12.4)y, range 20-70y. \\
& Milnacipran 150-300/200mg: N=86 (150-300mg:N=42, 200mg:N=44) \\
\hline Interventions & Fluvoxamine 200mg: N=41 \\
& Fixed dosing schedule. \\
\hline Outcomes & Hamilton Depression Rating Scale-24 item, MADRS,CGI-I, CGI-S \\
\hline Notes & Funding: by industry \\
\hline Risk of bias & \\
\hline Item & Authors' judgement $\quad$ Description \\
\hline Adequate sequence generation? & Yes \\
\hline
\end{tabular}




\begin{tabular}{lll} 
Allocation concealment? & Unclear & Insufficient information. \\
\hline $\begin{array}{l}\text { Blinding? } \\
\text { All outcomes }\end{array}$ & Yes & Quote: “double-blind” \\
\hline $\begin{array}{l}\text { Incomplete outcome data addressed? } \\
\text { All outcomes }\end{array}$ & Yes & No missing primary outcome data. \\
\hline Free of selective reporting? & No & Some missing standard deviations. \\
\hline $\begin{array}{l}\text { Free of other bias? } \\
\text { Unclear }\end{array}$ & & $\begin{array}{l}\text { Insufficient information to assess whether an } \\
\text { important risk of bias exists }\end{array}$ \\
\hline
\end{tabular}

\section{Annseau 1994}

\begin{tabular}{|c|c|c|}
\hline Methods & \multicolumn{2}{|c|}{6 week randomised double blind study } \\
\hline Participants & \multicolumn{2}{|c|}{$\begin{array}{l}\text { Diagnosis: Outpatients with DSM-III-R major depressive episode } \\
\text { Male and Female. } \\
\text { Threshold of baseline severity: MADRS }>=25 \text {, CGI-S }<=4 \text {, Raskin Scale for } \\
\text { Depression>Covi Anxiety Scale } \\
\text { Total number of all allocated participants: } N=190 \\
\text { Age: mean } 44.9 \text { (SD 11.2)y, range 19-68y. }\end{array}$} \\
\hline Interventions & \multicolumn{2}{|c|}{$\begin{array}{l}\text { Milnacipran 100mg: N=97 } \\
\text { Fluoxetine 20mg: N=93 } \\
\text { Fixed dosing schedule. }\end{array}$} \\
\hline Outcomes & \multicolumn{2}{|c|}{$\begin{array}{l}\text { Hamilton Depression Rating Scale-24 item, MADRS,CGI-I, CGI-S, CGI-E, 100mm } \\
\text { VAS for depressed mood, psychomotor retardation, anxiety and insomnia }\end{array}$} \\
\hline Notes & \multicolumn{2}{|l|}{ Funding: by industry } \\
\hline \multicolumn{3}{|l|}{ Risk of bias } \\
\hline Item & Authors' judgement & Description \\
\hline $\begin{array}{l}\text { Adequate sequence } \\
\text { generation? } \\
\text { Allocation } \\
\text { concealment? }\end{array}$ & $\begin{array}{l}\text { Yes } \\
\text { Unclear }\end{array}$ & $\begin{array}{l}\text { Quote: "randomly assigned". Probably done. } \\
\text { Insufficient information. }\end{array}$ \\
\hline $\begin{array}{l}\text { Blinding? } \\
\text { All outcomes }\end{array}$ & Yes & Quote: "double-blind" \\
\hline $\begin{array}{l}\text { Incomplete outcome } \\
\text { data addressed? } \\
\text { All outcomes }\end{array}$ & No & $\begin{array}{l}\text { Some of actual figures of outcome data are missing. Incoherence } \\
\text { between denominators }\end{array}$ \\
\hline $\begin{array}{l}\text { Free of selective } \\
\text { reporting? }\end{array}$ & No & No data of participants who experienced at least some side effects \\
\hline Free of other bias? & Unclear & $\begin{array}{l}\text { Insufficient information to assess whether an important risk of bias } \\
\text { exists }\end{array}$ \\
\hline
\end{tabular}

Clerc 2001

\begin{tabular}{ll}
\hline Methods & 6 week randomised double blind study \\
\hline Participants & Diagnosis: Outpatients with DSM-III-R major depressive episode \\
& Male and Female. \\
& Threshold of baseline severity: MADRS $>=25$, Raskin Scale for Depression \\
& Total number of all allocated participants: N=113 \\
& Age: mean 48.7 (SD 15.1)y for milnacipran, mean 51.2 (SD 12.6)y for \\
& fluvoxamine \\
\hline Interventions & Milnacipran $100 \mathrm{mg}: \mathrm{N}=57$
\end{tabular}

Cochrane Database Syst Rev. Author manuscript; available in PMC 2014 September 16. 
Fluvoxamine 200mg: $\mathrm{N}=56$

Fixed dosing schedule.

\begin{tabular}{|c|c|c|}
\hline Outcomes & \multicolumn{2}{|c|}{ Hamilton Depression Rating Scale-24 item, MADRS,CGI-I, CGI-S, CGI-E } \\
\hline Notes & \multicolumn{2}{|l|}{ Funding: by industry } \\
\hline \multicolumn{3}{|l|}{ Risk of bias } \\
\hline Item & Authors' judgement & Description \\
\hline Adequate sequence generation? & Yes & Quote: "randomised". Probably done. \\
\hline Allocation concealment? & Unclear & Insufficient information. \\
\hline $\begin{array}{l}\text { Blinding? } \\
\text { All outcomes }\end{array}$ & Yes & Quote: "double-blind" \\
\hline $\begin{array}{l}\text { Incomplete outcome data addressed? } \\
\text { All outcomes }\end{array}$ & Yes & No missing primary outcome data. \\
\hline Free of selective reporting? & Yes & $\begin{array}{l}\text { The study protocol is not available but it is clear that } \\
\text { the published reports include all expected outcomes, } \\
\text { including those that were pre-specified }\end{array}$ \\
\hline Free of other bias? & Unclear & $\begin{array}{l}\text { Insufficient information to assess whether an important } \\
\text { risk of bias exists }\end{array}$ \\
\hline
\end{tabular}

Endo 1995

\begin{tabular}{|c|c|c|}
\hline Methods & \multicolumn{2}{|c|}{4 week randomised double blind study } \\
\hline Participants & \multicolumn{2}{|c|}{$\begin{array}{l}\text { Diagnosis: In- and Out-patients with DSM-III-R major depressive episode } \\
\text { Male and Female. } \\
\text { Threshold of baseline severity: Not reported. } \\
\text { Total number of all allocated participants: } \mathrm{N}=179 \\
\text { Age: range } 20-65 \mathrm{y}\end{array}$} \\
\hline Interventions & \multicolumn{2}{|c|}{$\begin{array}{l}\text { Milnacipran } 50-150 \mathrm{mg} \text { (mean: } 68.6 \mathrm{mg}): \mathrm{N}=84 \\
\text { Mianserine } 30-60 \mathrm{mg}: \mathrm{N}=95 \\
\text { Flexible dosing schedule. }\end{array}$} \\
\hline Outcomes & \multicolumn{2}{|c|}{ Hamilton Depression Rating Scale-21 item, CGI-I, CPRG } \\
\hline Notes & \multicolumn{2}{|l|}{$\begin{array}{l}\text { Funding: by industry } \\
\text { Article in Japanese. }\end{array}$} \\
\hline \multicolumn{3}{|l|}{ Risk of bias } \\
\hline Item & Authors' judgement & Description \\
\hline Adequate sequence generation? & Yes & Quote: "randomised". Probably done. \\
\hline Allocation concealment? & Yes & Central allocation used. \\
\hline $\begin{array}{l}\text { Blinding? } \\
\text { All outcomes }\end{array}$ & Yes & Quote: "double-blind"“ \\
\hline $\begin{array}{l}\text { Incomplete outcome data addressed? } \\
\text { All outcomes }\end{array}$ & Yes & No missing primary outcome data. \\
\hline Free of selective reporting? & Yes & $\begin{array}{l}\text { The study protocol is not available but it is clear that } \\
\text { the published reports include all expected outcomes, } \\
\text { including those that were pre-specified }\end{array}$ \\
\hline Free of other bias? & Unclear & $\begin{array}{l}\text { Insufficient information to assess whether an important } \\
\text { risk of bias exists }\end{array}$ \\
\hline
\end{tabular}

Guelfi 1998a

Cochrane Database Syst Rev. Author manuscript; available in PMC 2014 September 16. 


\begin{tabular}{|c|c|c|}
\hline Methods & \multicolumn{2}{|c|}{12 week randomised double blind study } \\
\hline Participants & \multicolumn{2}{|c|}{$\begin{array}{l}\text { Diagnosis: Inpatients with DSM-III-R major depression } \\
\text { Male and Female. } \\
\text { Threshold of baseline severity: HDRS-17>=22, Newcastle scale }>=6 \text {, HDRS } \\
\text { specific endogenous subscale }>=8 \\
\text { Total number of all allocated participants: N=300 } \\
\text { Age: mean } 45.6 \text { (SD 12.8)y for milnacipran } 100 \mathrm{mg} \text {, mean } 45.2 \text { (SD 12.5)y for } \\
\text { milnacipran } 200 \mathrm{mg} \text {, mean } 45.8 \text { (SD 12.8)y for fluoxetine; range } 18-70 \mathrm{y}\end{array}$} \\
\hline Interventions & \multicolumn{2}{|c|}{$\begin{array}{l}\text { Milnacipran 100/200mg: } \mathrm{N}=200(100 \mathrm{mg}: \mathrm{N}=100,200 \mathrm{mg}: \mathrm{N}=100) \\
\text { Fluoxetine 20mg: } \mathrm{N}=100 \\
\text { Fixed dosing schedule. }\end{array}$} \\
\hline Outcomes & \multicolumn{2}{|c|}{ Hamilton Depression Rating Scale-17 item, MADRS, CGI-S } \\
\hline Notes & \multicolumn{2}{|l|}{ Funding: by industry } \\
\hline \multicolumn{3}{|l|}{ Risk of bias } \\
\hline Item & Authors' judgement & Description \\
\hline Adequate sequence generation? & Yes & Quote: "randomised". Probably done. \\
\hline Allocation concealment? & Unclear & Insufficient information. \\
\hline $\begin{array}{l}\text { Blinding? } \\
\text { All outcomes }\end{array}$ & Yes & Quote: "double-blind" \\
\hline $\begin{array}{l}\text { Incomplete outcome data } \\
\text { addressed? } \\
\text { All outcomes }\end{array}$ & No & $\begin{array}{l}\text { Missing primary outcome data at early } \\
\text { phase. }\end{array}$ \\
\hline Free of selective reporting? & No & Some missing standard deviations. \\
\hline Free of other bias? & Unclear & $\begin{array}{l}\text { Insufficient information to assess whether } \\
\text { an important risk of bias exists }\end{array}$ \\
\hline
\end{tabular}

Lee $2002 b$

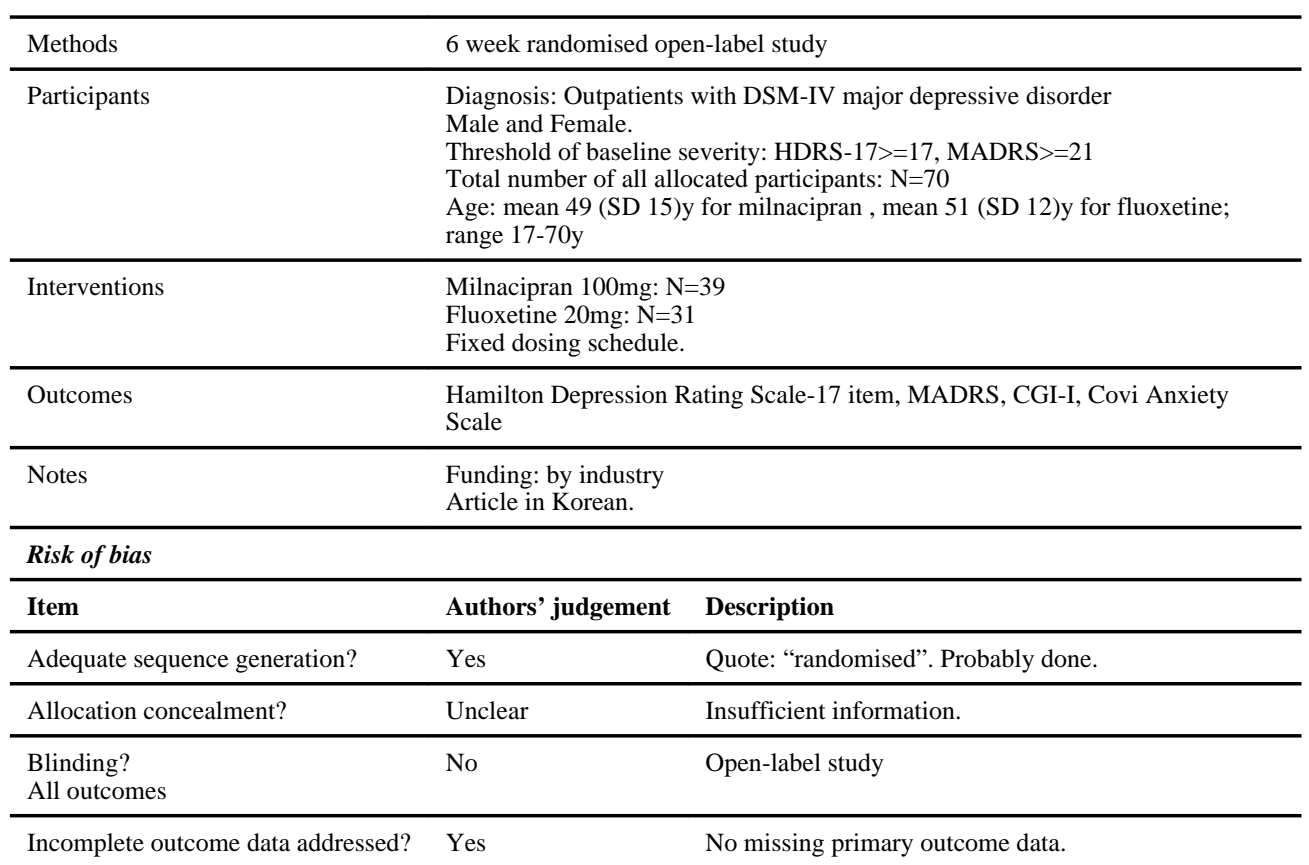

Cochrane Database Syst Rev. Author manuscript; available in PMC 2014 September 16. 
All outcomes

\begin{tabular}{lll}
\hline Free of selective reporting? & Unclear & Insufficient information. \\
\hline Free of other bias? & Unclear & $\begin{array}{l}\text { Insufficient information to assess whether an important } \\
\text { risk of bias exists }\end{array}$ \\
\hline
\end{tabular}

\section{Leinonen 1997}

\begin{tabular}{|c|c|c|}
\hline Methods & \multicolumn{2}{|c|}{26 week randomised double blind study } \\
\hline Participants & \multicolumn{2}{|c|}{$\begin{array}{l}\text { Diagnosis: In- and Out-patients with DSM-III-R major depressive episode } \\
\text { Male and Female. } \\
\text { Threshold of baseline severity: HDRS-17>=18, CGI>=moderately ill } \\
\text { Total number of all allocated participants: N=107 } \\
\text { Age: mean } 49.2 \text { (SD 9.8)y for milnacipran, mean } 47.1 \text { (SD 10.6)y for } \\
\text { clomipramine; range } 18-70 y\end{array}$} \\
\hline Interventions & \multicolumn{2}{|c|}{$\begin{array}{l}\text { Milnacipran 100-200mg: } \mathrm{N}=52 \\
\text { Clomipramine } 75-150 \mathrm{mg}: \mathrm{N}=55 \\
\text { Flexible dosing schedule. }\end{array}$} \\
\hline Outcomes & \multicolumn{2}{|c|}{ Hamilton Depression Rating Scale-17 item, MADRS, CGI-S } \\
\hline Notes & \multicolumn{2}{|l|}{ Funding: by industry } \\
\hline \multicolumn{3}{|l|}{ Risk of bias } \\
\hline Item & Authors' judgement & Description \\
\hline Adequate sequence generation? & Yes & Quote: "randomised". Probably done. \\
\hline Allocation concealment? & Unclear & Insufficient information. \\
\hline $\begin{array}{l}\text { Blinding? } \\
\text { All outcomes }\end{array}$ & Yes & Quote: "double-blind" \\
\hline $\begin{array}{l}\text { Incomplete outcome data addressed? } \\
\text { All outcomes }\end{array}$ & Yes & No missing primary outcome. \\
\hline Free of selective reporting? & No & $\begin{array}{l}\text { Number of participants who dropped out the trial is } \\
\text { missing. }\end{array}$ \\
\hline Free of other bias? & Unclear & $\begin{array}{l}\text { Insufficient information to assess whether an important } \\
\text { risk of bias exists }\end{array}$ \\
\hline
\end{tabular}

Lopez-Ibor 2004

\begin{tabular}{ll}
\hline Methods & 6 week randomised double blind study \\
\hline Participants & Diagnosis: Inpatients with DSM-III-R major depressive episode \\
& Male and Female. \\
& Threshold of baseline severity: MADRS $>=25$ \\
& Total number of all allocated participants: $\mathrm{N}=100$ \\
& Age: range $18-70 \mathrm{y}$ \\
\hline Interventions & Milnacipran $100 \mathrm{mg}: \mathrm{N}=51$ \\
& Imipramine $150 \mathrm{mg}: \mathrm{N}=49$ \\
& Fixed dosing schedule. \\
\hline Outcomes & Hamilton Depression Rating Scale-21 item, MADRS, 100mm VAS for \\
\hline Notes & subjective depression \\
\hline Risk of bias & Funding: by industry \\
\hline
\end{tabular}

Cochrane Database Syst Rev. Author manuscript; available in PMC 2014 September 16. 


\begin{tabular}{lll} 
Item & Authors' judgement & Description \\
\hline Adequate sequence generation? & Yes & Quote: "randomised" \\
\hline Allocation concealment? & Unclear & Unclear \\
\hline $\begin{array}{l}\text { Blinding? } \\
\text { All outcomes }\end{array}$ & Yes & Quote: "double-blind" \\
\hline $\begin{array}{l}\text { Incomplete outcome data addressed? } \\
\text { All outcomes }\end{array}$ & Yes & No missing primary outcome data. \\
\hline $\begin{array}{l}\text { Free of selective reporting? } \\
\text { Free of other bias? }\end{array}$ & Unclear & $\begin{array}{l}\text { Number of patient receiving each intervention at the } \\
\text { early phase is unclear }\end{array}$ \\
\hline
\end{tabular}

\section{Sechter 2000}

\begin{tabular}{|c|c|c|}
\hline Methods & \multicolumn{2}{|c|}{6 week randomised double blind study } \\
\hline Participants & \multicolumn{2}{|c|}{$\begin{array}{l}\text { Diagnosis: Outpatients with DSM-IV major depressive disorder } \\
\text { Male and Female. } \\
\text { Threshold of baseline severity: MADRS }>=20 \\
\text { Total number of all allocated participants: N=302 } \\
\text { Age: mean } 44.8 \text { (SD 11.6)y for milnacipran, mean } 42.8 \text { (SD 11.2)y for } \\
\text { paroxetine; range 18-70y }\end{array}$} \\
\hline Interventions & \multicolumn{2}{|c|}{$\begin{array}{l}\text { Milnacipran 100mg: } \mathrm{N}=149 \\
\text { Imipramine 20mg: } \mathrm{N}=153 \\
\text { Fixed dosing schedule. }\end{array}$} \\
\hline Outcomes & \multicolumn{2}{|c|}{ Hamilton Depression Rating Scale-17 item, MADRS, CGI-I, CGI-S } \\
\hline Notes & \multicolumn{2}{|l|}{ Funding: by industry } \\
\hline \multicolumn{3}{|l|}{ Risk of bias } \\
\hline Item & Authors' judgement & Description \\
\hline Adequate sequence generation? & Yes & Quote: "randomised” \\
\hline Allocation concealment? & Unclear & Unclear \\
\hline $\begin{array}{l}\text { Blinding? } \\
\text { All outcomes }\end{array}$ & Yes & Quote: "double-blind" \\
\hline $\begin{array}{l}\text { Incomplete outcome data addressed? } \\
\text { All outcomes }\end{array}$ & Yes & No missing primary outcome. \\
\hline Free of selective reporting? & No & Missing standard deviations. \\
\hline Free of other bias? & Unclear & $\begin{array}{l}\text { Insufficient information to assess whether an important } \\
\text { risk of bias exists }\end{array}$ \\
\hline
\end{tabular}

Shinkai 2004

\begin{tabular}{ll}
\hline Methods & 4 week randomised double blind study \\
\hline Participants & Diagnosis: Inpatients with DSM-IV major depressive disorder without \\
& psychotic features Male \\
& and Female. \\
& Threshold of baseline severity: HDRS-17>=15 \\
& Total number of all allocated participants: N=41 \\
& Age: mean 53 (SD 17)y; range 20-78y \\
\hline
\end{tabular}




\begin{tabular}{|c|c|c|}
\hline Interventions & \multicolumn{2}{|c|}{$\begin{array}{l}\text { Milnacipran mean } 80.25 \mathrm{mg}: \mathrm{N}=20 \\
\text { Paroxetine mean } 34.28 \mathrm{mg}: \mathrm{N}=21 \\
\text { Flexible dosing schedule. }\end{array}$} \\
\hline Outcomes & \multicolumn{2}{|c|}{ Hamilton Depression Rating Scale-17 item } \\
\hline Notes & \multicolumn{2}{|c|}{ Funding: independent from industry } \\
\hline \multicolumn{3}{|l|}{ Risk of bias } \\
\hline Item & Authors' judgement & Description \\
\hline Adequate sequence generation? & Yes & Quote: "randomly" \\
\hline Allocation concealment? & Yes & $\begin{array}{l}\text { Quote: "randomly divided into either milnacipran or } \\
\text { the paroxetine group using StatView, a computerized } \\
\text { statistical package" }\end{array}$ \\
\hline $\begin{array}{l}\text { Blinding? } \\
\text { All outcomes }\end{array}$ & Unclear & No information provided. \\
\hline $\begin{array}{l}\text { Incomplete outcome data addressed? } \\
\text { All outcomes }\end{array}$ & Yes & No missing primary outcome. \\
\hline Free of selective reporting? & No & $\begin{array}{l}\text { Adverse events were not reported so that could not be } \\
\text { entered in to the meta-analysis }\end{array}$ \\
\hline Free of other bias? & Unclear & $\begin{array}{l}\text { Insufficient information to assess whether an important } \\
\text { risk of bias exists }\end{array}$ \\
\hline
\end{tabular}

\section{Tignol 1998}

\begin{tabular}{|c|c|c|}
\hline Methods & \multicolumn{2}{|c|}{8 week randomised double blind study } \\
\hline Participants & \multicolumn{2}{|c|}{$\begin{array}{l}\text { Diagnosis: In- and Out-patients with DSM-III-R major depressive episode } \\
\text { Male and Female. } \\
\text { Threshold of baseline severity: HDRS-17>=17, MADRS }>=25 \text {, improvement } \\
\text { during washout phase less than } 25 \% \text { of the initial score, MMSE }>=20 \\
\text { Total number of all allocated participants: N=221 } \\
\text { Age: mean } 74.0 \text { (SD 6.2)y for milnacipran, mean } 74.2 \text { (SD 6.8)y for imipramine; } \\
\text { range } 65-93 y\end{array}$} \\
\hline Interventions & \multicolumn{2}{|c|}{$\begin{array}{l}\text { Milnacipran } 75-100 \mathrm{mg} \mathrm{N}=112 \\
\text { Imipramine } 75-100 \mathrm{mg} \mathrm{N}=109 \\
\text { Flexible dosing schedule. }\end{array}$} \\
\hline Outcomes & \multicolumn{2}{|c|}{$\begin{array}{l}\text { Hamilton Depression Rating Scale-17 item, MADRS, CGI-I, CGI-S, Covi } \\
\text { Anxiety Scale, WAIS, Digit Symbol Substitution Test (DSST), Word-paired test, } \\
\text { MMSE, Functional Status Questionnaire (FSQ) }\end{array}$} \\
\hline Notes & \multicolumn{2}{|l|}{ Funding: by industry } \\
\hline \multicolumn{3}{|l|}{ Risk of bias } \\
\hline Item & Authors' judgement & Description \\
\hline Adequate sequence generation? & Yes & Quote: "randomised". Probably done. \\
\hline Allocation concealment? & Unclear & Insufficient information. \\
\hline $\begin{array}{l}\text { Blinding? } \\
\text { All outcomes }\end{array}$ & Yes & Quote: "double-blind" \\
\hline $\begin{array}{l}\text { Incomplete outcome data } \\
\text { addressed? } \\
\text { All outcomes }\end{array}$ & No & Missing primary outcome at early phase. \\
\hline Free of selective reporting? & No & $\begin{array}{l}\text { MADRS scores were reported } \\
\text { incompletely. Missing standard deviations }\end{array}$ \\
\hline Free of other bias? & Unclear & $\begin{array}{l}\text { Insufficient information to assess whether } \\
\text { an important risk of bias exists }\end{array}$ \\
\hline
\end{tabular}

Cochrane Database Syst Rev. Author manuscript; available in PMC 2014 September 16. 
Van Amerongen 2002

\begin{tabular}{|c|c|c|}
\hline Methods & \multicolumn{2}{|c|}{6 week randomised double blind study } \\
\hline Participants & \multicolumn{2}{|c|}{$\begin{array}{l}\text { Diagnosis: Inpatients with DSM-III major depression } \\
\text { Male and Female. } \\
\text { Threshold of baseline severity: HDRS-17>=17, MADRS }>=25 \text {, improvement } \\
\text { during washout phase less than } 25 \% \text { of the initial score, MMSE }>=20 \\
\text { Total number of all allocated participants: } N=109 \\
\text { Age: mean } 46.7 \mathrm{y} \text { (range } 23-70 \mathrm{y} \text { ) for milnacipran, mean } 45.9 \text { y (range } 20-71 \mathrm{y} \text { ) for } \\
\text { imipramine; range } 18-70 \mathrm{y} \text { for total sample }\end{array}$} \\
\hline Interventions & \multicolumn{2}{|c|}{$\begin{array}{l}\text { Milnacipran } 100 \mathrm{mg} \mathrm{N}=53 \\
\text { Imipramine } 150 \mathrm{mg} \mathrm{N}=56 \\
\text { Fixed dosing schedule. }\end{array}$} \\
\hline Outcomes & \multicolumn{2}{|c|}{$\begin{array}{l}\text { Hamilton Depression Rating Scale-21 item, MADRS, CGI-3, 100mm VAS for } \\
\text { subjective depression }\end{array}$} \\
\hline Notes & \multicolumn{2}{|l|}{ Funding: by industry } \\
\hline \multicolumn{3}{|l|}{ Risk of bias } \\
\hline Item & Authors' judgement & Description \\
\hline Adequate sequence generation? & Yes & Quote: "randomised". Probably done. \\
\hline Allocation concealment? & Unclear & Insufficient information. \\
\hline $\begin{array}{l}\text { Blinding? } \\
\text { All outcomes }\end{array}$ & Yes & Quote: "double-blind" \\
\hline $\begin{array}{l}\text { Incomplete outcome data } \\
\text { addressed? } \\
\text { All outcomes }\end{array}$ & No & Missing primary outcome at early phase. \\
\hline Free of selective reporting? & No & Missing standard deviations. \\
\hline Free of other bias? & Unclear & $\begin{array}{l}\text { Insufficient information to assess whether } \\
\text { an important risk of bias exists }\end{array}$ \\
\hline
\end{tabular}

Yamashita 1995

\begin{tabular}{|c|c|c|}
\hline Methods & \multicolumn{2}{|c|}{4 week randomised double blind study } \\
\hline Participants & \multicolumn{2}{|c|}{$\begin{array}{l}\text { Diagnosis: In- and Out- patients with DSM-III-R major depressive episode } \\
\text { Male and Female. } \\
\text { Threshold of baseline severity: Not reported. } \\
\text { Total number of all allocated participants: } \mathrm{N}=132 \\
\text { Age: range } 20-65 \mathrm{y} \text { for total sample }\end{array}$} \\
\hline Interventions & \multicolumn{2}{|c|}{$\begin{array}{l}\text { Milnacipran 50-150mg (mean: } 77.2 \mathrm{mg} \text { ) N=66 } \\
\text { Imipramine 50-150mg (mean: } 89.1 \mathrm{mg} \text { ) N=66 } \\
\text { Flexible dosing schedule }\end{array}$} \\
\hline Outcomes & \multicolumn{2}{|c|}{ Hamilton Depression Rating Scale-21 item, CGI-I, CPRG } \\
\hline Notes & \multicolumn{2}{|l|}{$\begin{array}{l}\text { Funding: by industry } \\
\text { Article in Japanese. }\end{array}$} \\
\hline \multicolumn{3}{|l|}{ Risk of bias } \\
\hline Item & Authors' judgement & Description \\
\hline Adequate sequence generation? & Yes & Quote: "randomised". Probably done. \\
\hline Allocation concealment? & Yes & Cental allocation used. \\
\hline $\begin{array}{l}\text { Blinding? } \\
\text { All outcomes }\end{array}$ & Yes & Quote: "double-blind" \\
\hline
\end{tabular}




\begin{tabular}{lll}
$\begin{array}{l}\text { Incomplete outcome data addressed? } \\
\text { All outcomes }\end{array}$ & Yes & No missing primary outcome data. \\
\hline Free of selective reporting? & Yes & $\begin{array}{l}\text { The study protocol is not available but it is clear that } \\
\text { the published reports include all expected outcomes, } \\
\text { including those that were pre-specified }\end{array}$ \\
\hline Free of other bias? & Unclear & $\begin{array}{l}\text { Insufficient information to assess whether an important } \\
\text { risk of bias exists }\end{array}$ \\
\hline
\end{tabular}

Yang 2003

\begin{tabular}{|c|c|c|}
\hline Methods & \multicolumn{2}{|c|}{8 week randomised double blind study } \\
\hline Participants & \multicolumn{2}{|c|}{$\begin{array}{l}\text { Diagnosis: Outpatients with DSM-IV major depressive disorder } \\
\text { Male and Female. } \\
\text { Threshold of baseline severity: HDRS-17>=17 } \\
\text { Total number of all allocated participants: } \mathrm{N}=53 \\
\text { Age: not shown }\end{array}$} \\
\hline Interventions & \multicolumn{2}{|c|}{$\begin{array}{l}\text { Milnacipran } 100 \mathrm{mg} \mathrm{N}=27 \\
\text { Sertraline } 100 \mathrm{mg} \mathrm{N}=26 \\
\text { Flexible dosing schedule }\end{array}$} \\
\hline Outcomes & \multicolumn{2}{|c|}{ Hamilton Depression Rating Scale-17 item, MADRS, CGI-I, CGI-S } \\
\hline Notes & \multicolumn{2}{|l|}{$\begin{array}{l}\text { Funding: by industry } \\
\text { Article in Korean. }\end{array}$} \\
\hline \multicolumn{3}{|l|}{ Risk of bias } \\
\hline Item & Authors' judgement & Description \\
\hline Adequate sequence generation? & Yes & Quote: "randomised". Probably done. \\
\hline Allocation concealment? & Unclear & Insufficient information. \\
\hline $\begin{array}{l}\text { Blinding? } \\
\text { All outcomes }\end{array}$ & Yes & Quote: "double-blind" \\
\hline $\begin{array}{l}\text { Incomplete outcome data addressed? } \\
\text { All outcomes }\end{array}$ & No & Primary outcome data missing. \\
\hline Free of selective reporting? & No & $\begin{array}{l}\text { Adverse events are not reported so that could not be } \\
\text { entered in a meta-analysis }\end{array}$ \\
\hline Free of other bias? & Unclear & $\begin{array}{l}\text { Insufficient information to assess whether an important } \\
\text { risk of bias exists }\end{array}$ \\
\hline
\end{tabular}

\section{Characteristics of excluded studies [ordered by study ID]}

\begin{tabular}{ll}
\hline Study & Reason for exclusion \\
\hline Baek 2002a & Did not use relevant operational diagnostic criteria. \\
\hline Baek 2002b & Additional publication of trial already included. \\
\hline Dardennes 1998 & Did not include acute phase treatment. \\
\hline Kanemoto 2004 & Did not use other antidepressant as a comparator drug. \\
\hline Lee 2004 & Additional publication of trial already included. \\
\hline Macher 1989 & Did not use other antidepressant as a comparator drug. \\
\hline Naito 2007 & $\begin{array}{l}\text { Secondary analysis of separate two studies (Ito 2002; Yoshida 2002), thus not a concurrent } \\
\text { comparison study }\end{array}$ \\
\hline
\end{tabular}




\begin{tabular}{ll}
\hline Study & Reason for exclusion \\
\hline Onodera 1992 & Additional publication of trial already included. \\
\hline Wyeth 2006 & Method of allocation was not randomised (e.g. controlled clinical trial) \\
\hline
\end{tabular}

\section{Characteristics of studies awaiting assessment [ordered by study ID]}

Yoshimura 2007

\begin{tabular}{ll}
\hline Methods & RCT \\
\hline Participants & 42 Japanese adults \\
\hline Interventions & paroxetine vs milnacipran \\
\hline Outcomes & Serum BDNF levels, response and remission rates \\
\hline Notes & \\
\hline
\end{tabular}

\section{DATA AND ANALYSES}

\section{Comparison 1}

Response at acute phase (6-12 weeks)

\begin{tabular}{|c|c|c|c|c|}
\hline $\begin{array}{l}\text { Outcome or subgroup } \\
\text { title }\end{array}$ & No. of studies & No. of participants & Statistical method & Effect size \\
\hline $\begin{array}{l}1 \text { Milnacipran vs } \\
\text { TCAs }\end{array}$ & 4 & 537 & $\begin{array}{l}\text { Odds Ratio (M-H, Random, } \\
95 \% \text { CI) }\end{array}$ & $0.87[0.59,1.30]$ \\
\hline $\begin{array}{l}\text { 1.1 Milnacipran vs } \\
\text { Imipramine }\end{array}$ & 3 & 430 & $\begin{array}{l}\text { Odds Ratio (M-H, Random, } \\
95 \% \text { CI) }\end{array}$ & $1.05[0.71,1.54]$ \\
\hline $\begin{array}{l}\text { 1.2 Milancipran vs } \\
\text { Clomipramine }\end{array}$ & 1 & 107 & $\begin{array}{l}\text { Odds Ratio (M-H, Random, } \\
95 \% \text { CI) }\end{array}$ & $0.45[0.21,0.98]$ \\
\hline $\begin{array}{l}2 \text { Milnacipran vs } \\
\text { SSRIs }\end{array}$ & 6 & 1028 & $\begin{array}{l}\text { Odds Ratio (M-H, Random, } \\
95 \% \text { CI) }\end{array}$ & $1.11[0.76,1.64]$ \\
\hline $\begin{array}{l}2.1 \text { Milnacipran vs } \\
\text { Fluvoxamine }\end{array}$ & 1 & 113 & $\begin{array}{l}\text { Odds Ratio (M-H, Random, } \\
95 \% \text { CI) }\end{array}$ & $1.76[0.81,3.83]$ \\
\hline $\begin{array}{l}2.2 \text { Milnacipran vs } \\
\text { Fluoxetine }\end{array}$ & 3 & 560 & $\begin{array}{l}\text { Odds Ratio (M-H, Random, } \\
95 \% \text { CI) }\end{array}$ & $0.93[0.55,1.58]$ \\
\hline $\begin{array}{l}2.3 \text { Milnacipran vs } \\
\text { Paroxetine }\end{array}$ & 1 & 302 & $\begin{array}{l}\text { Odds Ratio (M-H, Random, } \\
95 \% \text { CI) }\end{array}$ & $0.93[0.59,1.47]$ \\
\hline $\begin{array}{l}\text { 2.4 Milnacipran vs } \\
\text { Sertraline }\end{array}$ & 1 & 53 & $\begin{array}{l}\text { Odds Ratio (M-H, Random, } \\
95 \% \text { CI) }\end{array}$ & $3.83[0.90,16.26]$ \\
\hline
\end{tabular}

\section{Comparison 2}

Response at early phase (1-4 weeks)

\begin{tabular}{lccll}
\hline $\begin{array}{l}\text { Outcome or subgroup } \\
\text { title }\end{array}$ & No. of studies & No. of participants & Statistical method & Effect size \\
\hline 1 Milnacipran vs TCAs & 6 & 802 & $\begin{array}{l}\text { Odds Ratio (M-H, Random, } \\
95 \% \text { CI) }\end{array}$ & $0.83[0.58,1.20]$ \\
$\begin{array}{l}\text { 1.1 Milancipran vs } \\
\begin{array}{l}\text { Imipramine } \\
\text { Im }\end{array}\end{array}$ & 3 & 462 & $\begin{array}{l}\text { Odds Ratio (M-H, Random, } \\
95 \% \text { CI) }\end{array}$ & $1.11[0.73,1.69]$
\end{tabular}




\begin{tabular}{|c|c|c|c|c|}
\hline $\begin{array}{l}\text { Outcome or subgroup } \\
\text { title }\end{array}$ & No. of studies & No. of participants & Statistical method & Effect size \\
\hline $\begin{array}{l}\text { 1.2 Milnacipran vs } \\
\text { Clomipramine }\end{array}$ & 1 & 107 & $\begin{array}{l}\text { Odds Ratio (M-H, Random, } \\
95 \% \text { CI) }\end{array}$ & $0.46[0.17,1.24]$ \\
\hline $\begin{array}{l}\text { 1.3 Milnacipran vs } \\
\text { Amitriptyline }\end{array}$ & 2 & 233 & $\begin{array}{l}\text { Odds Ratio (M-H, Random, } \\
95 \% \text { CI) }\end{array}$ & $0.62[0.35,1.08]$ \\
\hline 2 Milancipran vs SSRIs & 6 & 953 & $\begin{array}{l}\text { Odds Ratio (M-H, Random, } \\
95 \% \text { CI) }\end{array}$ & $1.30[0.97,1.73]$ \\
\hline $\begin{array}{l}\text { 2.1 Milnacipran vs } \\
\text { Fluvoxamine }\end{array}$ & 2 & 240 & $\begin{array}{l}\text { Odds Ratio (M-H, Random, } \\
95 \% \text { CI) }\end{array}$ & $1.54[0.87,2.72]$ \\
\hline $\begin{array}{l}2.2 \text { Milnacipran vs } \\
\text { Fluoxetine }\end{array}$ & 2 & 370 & $\begin{array}{l}\text { Odds Ratio (M-H, Random, } \\
95 \% \text { CI) }\end{array}$ & $1.49[0.93,2.37]$ \\
\hline $\begin{array}{l}2.3 \text { Milnacipran vs } \\
\text { Paroxetine }\end{array}$ & 2 & 343 & $\begin{array}{l}\text { Odds Ratio (M-H, Random, } \\
95 \% \text { CI) }\end{array}$ & $0.99[0.61,1.60]$ \\
\hline $\begin{array}{l}3 \text { Milnacipran vs } \\
\text { Heterocyclics }\end{array}$ & 1 & 179 & $\begin{array}{l}\text { Odds Ratio (M-H, Random, } \\
95 \% \text { CI) }\end{array}$ & $1.10[0.54,2.23]$ \\
\hline $\begin{array}{l}3.1 \text { Milancipran vs } \\
\text { Mianserin }\end{array}$ & 1 & 179 & $\begin{array}{l}\text { Odds Ratio (M-H, Random, } \\
95 \% \text { CI) }\end{array}$ & $1.10[0.54,2.23]$ \\
\hline
\end{tabular}

\section{Comparison 3}

Response at follow-up phase (4-6 months)

\begin{tabular}{lccll}
\hline $\begin{array}{l}\text { Outcome or subgroup } \\
\text { title }\end{array}$ & No. of studies & No. of participants & Statistical method & Effect size \\
\hline 1 Milnacipran vs TCAs & 1 & 107 & $\begin{array}{l}\text { Odds Ratio (M-H, Random, } \\
95 \% \text { CI) }\end{array}$ & $0.72[0.33,1.55]$ \\
$\begin{array}{l}1.1 \text { Milnacipran vs } \\
\text { Clomipramine }\end{array}$ & 1 & 107 & $\begin{array}{l}\text { Odds Ratio (M-H, Random, } \\
95 \% \text { CI) }\end{array}$ & $0.72[0.33,1.55]$ \\
\hline
\end{tabular}

Comparison 4

Remission at acute phase (6-12 weeks)

\begin{tabular}{|c|c|c|c|c|}
\hline $\begin{array}{l}\text { Outcome or subgroup } \\
\text { title }\end{array}$ & No. of studies & No. of participants & Statistical method & Effect size \\
\hline 1 Milnacipran vs TCAs & 4 & 537 & $\begin{array}{l}\text { Odds Ratio (M-H, Random, } \\
\text { 95\% CI) }\end{array}$ & $0.82[0.57,1.19]$ \\
\hline $\begin{array}{l}\text { 1.1 Milnacipran vs } \\
\text { Imipramine }\end{array}$ & 3 & 430 & $\begin{array}{l}\text { Odds Ratio (M-H, Random, } \\
95 \% \text { CI) }\end{array}$ & $0.94[0.62,1.41]$ \\
\hline $\begin{array}{l}\text { 1.2 Milnacipran vs } \\
\text { Clomipramine }\end{array}$ & 1 & 107 & $\begin{array}{l}\text { Odds Ratio (M-H, Random, } \\
95 \% \text { CI) }\end{array}$ & $0.43[0.17,1.07]$ \\
\hline 2 Milnacipran vs SSRIs & 6 & 1028 & $\begin{array}{l}\text { Odds Ratio (M-H, Random, } \\
\text { 95\% CI) }\end{array}$ & $0.98[0.73,1.32]$ \\
\hline $\begin{array}{l}\text { 2.1 Milnacipran vs } \\
\text { Fluvoxamine }\end{array}$ & 1 & 113 & $\begin{array}{l}\text { Odds Ratio (M-H, Random, } \\
95 \% \text { CI) }\end{array}$ & $1.48[0.66,3.30]$ \\
\hline $\begin{array}{l}2.2 \text { Milnacipran vs } \\
\text { Fluoxetine }\end{array}$ & 3 & 560 & $\begin{array}{l}\text { Odds Ratio (M-H, Random, } \\
95 \% \text { CI) }\end{array}$ & $0.91[0.56,1.46]$ \\
\hline $\begin{array}{l}2.3 \text { Milnacipran vs } \\
\text { Paroxetine }\end{array}$ & 1 & 302 & $\begin{array}{l}\text { Odds Ratio (M-H, Random, } \\
95 \% \text { CI) }\end{array}$ & $0.92[0.57,1.49]$ \\
\hline $\begin{array}{l}\text { 2.4 Milnacipran vs } \\
\text { Sertraline }\end{array}$ & 1 & 53 & $\begin{array}{l}\text { Odds Ratio (M-H, Random, } \\
95 \% \text { CI) }\end{array}$ & Not estimable \\
\hline
\end{tabular}


Comparison 5

Remission at early phase (1-4 weeks)

\begin{tabular}{|c|c|c|c|c|}
\hline $\begin{array}{l}\text { Outcome or subgroup } \\
\text { title }\end{array}$ & No. of studies & No. of participants & Statistical method & Effect size \\
\hline 1 Milnacipran vs TCAs & 6 & 802 & $\begin{array}{l}\text { Odds Ratio (M-H, Random, } \\
95 \% \text { CI) }\end{array}$ & $0.89[0.56,1.40]$ \\
\hline $\begin{array}{l}\text { 1.1 Milnacipran vs } \\
\text { Imipramine }\end{array}$ & 3 & 462 & $\begin{array}{l}\text { Odds Ratio (M-H, Random, } \\
95 \% \text { CI) }\end{array}$ & $1.03[0.59,1.79]$ \\
\hline $\begin{array}{l}\text { 1.2 Milnacipran vs } \\
\text { Clomipramine }\end{array}$ & 1 & 107 & $\begin{array}{l}\text { Odds Ratio (M-H, Random, } \\
95 \% \text { CI) }\end{array}$ & $0.69[0.11,4.33]$ \\
\hline $\begin{array}{l}\text { 1.3 Milnacipran vs } \\
\text { Amitriptyline }\end{array}$ & 2 & 233 & $\begin{array}{l}\text { Odds Ratio (M-H, Random, } \\
95 \% \text { CI) }\end{array}$ & $0.62[0.25,1.54]$ \\
\hline 2 Milnacipran vs SSRIs & 6 & 953 & $\begin{array}{l}\text { Odds Ratio (M-H, Random, } \\
95 \% \text { CI) }\end{array}$ & $1.28[0.77,2.14]$ \\
\hline $\begin{array}{l}\text { 2.1 Milnacipran vs } \\
\text { Fluvoxamine }\end{array}$ & 2 & 240 & $\begin{array}{l}\text { Odds Ratio (M-H, Random, } \\
95 \% \text { CI) }\end{array}$ & $1.36[0.52,3.58]$ \\
\hline $\begin{array}{l}2.2 \text { Milnacipran vs } \\
\text { Fluoxetine }\end{array}$ & 2 & 370 & $\begin{array}{l}\text { Odds Ratio (M-H, Random, } \\
95 \% \text { CI) }\end{array}$ & $1.72[0.71,4.17]$ \\
\hline $\begin{array}{l}2.3 \text { Milnacipran vs } \\
\text { Paroxetine }\end{array}$ & 2 & 343 & $\begin{array}{l}\text { Odds Ratio (M-H, Random, } \\
95 \% \text { CI) }\end{array}$ & $0.95[0.42,2.17]$ \\
\hline $\begin{array}{l}3 \text { Milnacipran vs } \\
\text { Heterocyclics }\end{array}$ & 1 & 179 & $\begin{array}{l}\text { Odds Ratio (M-H, Random, } \\
95 \% \text { CI) }\end{array}$ & $1.44[0.57,3.67]$ \\
\hline $\begin{array}{l}\text { 3.1 Milnacipran vs } \\
\text { Mianserin }\end{array}$ & 1 & 179 & $\begin{array}{l}\text { Odds Ratio (M-H, Random, } \\
95 \% \text { CI) }\end{array}$ & $1.44[0.57,3.67]$ \\
\hline
\end{tabular}

Comparison 6

Remission at follow-up phase (4-6 months)

\begin{tabular}{lcclc}
\hline $\begin{array}{l}\text { Outcome or subgroup } \\
\text { title }\end{array}$ & No. of studies & No. of participants & Statistical method & Effect size \\
\hline 1 Milnacipran vs TCAs & 1 & 107 & $\begin{array}{l}\text { Odds Ratio (M-H, Random, } \\
95 \% \text { CI) }\end{array}$ & $0.61[0.28,1.31]$ \\
$\begin{array}{l}\text { 1.1 Milnacipran vs } \\
\text { Clomipramine }\end{array}$ & 1 & 107 & $\begin{array}{l}\text { Odds Ratio (M-H, Random, } \\
95 \% \text { CI) }\end{array}$ & $0.61[0.28,1.31]$ \\
\hline
\end{tabular}

\section{Comparison 7}

Depression scale-end point score at acute phase (6-12 weeks)

\begin{tabular}{lcclc}
\hline $\begin{array}{l}\text { Outcome or } \\
\text { subgroup title }\end{array}$ & No. of studies & No. of participants & \multicolumn{1}{c}{ Statistical method } & Effect size \\
\hline $\begin{array}{l}\text { 1 Milnacipran vs } \\
\text { TCAs }\end{array}$ & 7 & 820 & $\begin{array}{l}\text { Std. Mean Difference (IV, } \\
\text { Random, 95\% CI) }\end{array}$ & $0.07[-0.07,0.21]$ \\
$\begin{array}{l}1.1 \text { Milnacipran vs } \\
\text { Imipramine }\end{array}$ & 4 & 509 & $\begin{array}{l}\text { Std. Mean Difference (IV, } \\
\text { Random, 95\% CI) }\end{array}$ & $0.02[-0.15,0.20]$ \\
$\begin{array}{l}1.2 \text { Milnacipran vs } \\
\text { Clomipramine }\end{array}$ & 1 & 93 & $\begin{array}{l}\text { Std. Mean Difference (IV, } \\
\text { Random, 95\% CI) }\end{array}$ & $0.44[0.03,0.85]$ \\
$\begin{array}{l}1.3 \text { Milancipran vs } \\
\text { Amitriptyline }\end{array}$ & 2 & 218 & $\begin{array}{l}\text { Std. Mean Difference (IV, } \\
\text { Random, 95\% CI) }\end{array}$ & $-0.00[-0.42,0.42]$
\end{tabular}




\begin{tabular}{|c|c|c|c|c|}
\hline $\begin{array}{l}\text { Outcome or } \\
\text { subgroup title }\end{array}$ & No. of studies & No. of participants & Statistical method & Effect size \\
\hline $\begin{array}{l}2 \text { Milnacipran vs } \\
\text { SSRIs }\end{array}$ & 8 & 963 & $\begin{array}{l}\text { Std. Mean Difference (IV, } \\
\text { Random, 95\% CI) }\end{array}$ & $0.04[-0.11,0.19]$ \\
\hline $\begin{array}{l}2.1 \text { Milnacipran vs } \\
\text { Fluvoxamine }\end{array}$ & 2 & 224 & $\begin{array}{l}\text { Std. Mean Difference (IV, } \\
\text { Random, 95\% CI) }\end{array}$ & $-0.14[-0.45,0.17]$ \\
\hline $\begin{array}{l}2.2 \text { Milnacipran vs } \\
\text { Fluoxetine }\end{array}$ & 3 & 372 & $\begin{array}{l}\text { Std. Mean Difference (IV, } \\
\text { Random, 95\% CI) }\end{array}$ & $0.10[-0.21,0.42]$ \\
\hline $\begin{array}{l}2.3 \text { Milnacipran vs } \\
\text { Paroxetine }\end{array}$ & 2 & 340 & $\begin{array}{l}\text { Std. Mean Difference (IV, } \\
\text { Random, 95\% CI) }\end{array}$ & $0.12[-0.09,0.33]$ \\
\hline $\begin{array}{l}\text { 2.4 Milnacipran vs } \\
\text { Sertraline }\end{array}$ & 1 & 27 & $\begin{array}{l}\text { Std. Mean Difference (IV, } \\
\text { Random, 95\% CI) }\end{array}$ & $-0.15[-0.91,0.61]$ \\
\hline $\begin{array}{l}3 \text { Milnacipran vs } \\
\text { Heterocyclics }\end{array}$ & 1 & 167 & $\begin{array}{l}\text { Std. Mean Difference (IV, } \\
\text { Random, 95\% CI) }\end{array}$ & $-0.12[-0.43,0.18]$ \\
\hline $\begin{array}{l}\text { 3.1 Milnacipran vs } \\
\text { Mianserin }\end{array}$ & 1 & 167 & $\begin{array}{l}\text { Std. Mean Difference (IV, } \\
\text { Random, 95\% CI) }\end{array}$ & $-0.12[-0.43,0.18]$ \\
\hline
\end{tabular}

Comparison 8

Depression scale-end point score at early phase (1-4 weeks)

\begin{tabular}{|c|c|c|c|c|}
\hline $\begin{array}{l}\text { Outcome or } \\
\text { subgroup title }\end{array}$ & No. of studies & No. of participants & Statistical method & Effect size \\
\hline $\begin{array}{l}1 \text { Milnacipran vs } \\
\text { TCAs }\end{array}$ & 6 & 765 & $\begin{array}{l}\text { Std. Mean Difference (IV, } \\
\text { Random, 95\% CI) }\end{array}$ & $0.14[-0.11,0.38]$ \\
\hline $\begin{array}{l}\text { 1.1 Milnacipran vs } \\
\text { Imipramine }\end{array}$ & 3 & 454 & $\begin{array}{l}\text { Std. Mean Difference (IV, } \\
\text { Random, 95\% CI) }\end{array}$ & $-0.02[-0.25,0.21]$ \\
\hline $\begin{array}{l}\text { 1.2 Milnacipran vs } \\
\text { Clomipramine }\end{array}$ & 1 & 93 & $\begin{array}{l}\text { Std. Mean Difference (IV, } \\
\text { Random, 95\% CI) }\end{array}$ & $0.66[0.25,1.08]$ \\
\hline $\begin{array}{l}\text { 1.3 Milancipran vs } \\
\text { Amitriptyline }\end{array}$ & 2 & 218 & $\begin{array}{l}\text { Std. Mean Difference (IV, } \\
\text { Random, 95\% CI) }\end{array}$ & $0.13[-0.22,0.48]$ \\
\hline $\begin{array}{l}2 \text { Milnacipran vs } \\
\text { SSRIs }\end{array}$ & 5 & 824 & $\begin{array}{l}\text { Std. Mean Difference (IV, } \\
\text { Random, 95\% CI) }\end{array}$ & $-0.05[-0.25,0.14]$ \\
\hline $\begin{array}{l}\text { 2.1 Milnacipran vs } \\
\text { Fluvoxamine }\end{array}$ & 2 & 233 & $\begin{array}{l}\text { Std. Mean Difference (IV, } \\
\text { Random, 95\% CI) }\end{array}$ & $-0.04[-0.31,0.22]$ \\
\hline $\begin{array}{l}2.2 \text { Milnacipran vs } \\
\text { Fluoxetine }\end{array}$ & 2 & 292 & $\begin{array}{l}\text { Std. Mean Difference (IV, } \\
\text { Random, 95\% CI) }\end{array}$ & $-0.01[-0.69,0.67]$ \\
\hline $\begin{array}{l}2.3 \text { Milnacipran vs } \\
\text { Paroxetine }\end{array}$ & 1 & 299 & $\begin{array}{l}\text { Std. Mean Difference (IV, } \\
\text { Random, 95\% CI) }\end{array}$ & Not estimable \\
\hline $\begin{array}{l}3 \text { Milnacipran vs } \\
\text { Heterocyclics }\end{array}$ & 1 & 121 & $\begin{array}{l}\text { Std. Mean Difference (IV, } \\
\text { Random, 95\% CI) }\end{array}$ & $-0.15[-0.51,0.21]$ \\
\hline $\begin{array}{l}\text { 3.1 Milnacipran vs } \\
\text { Mianserin }\end{array}$ & 1 & 121 & $\begin{array}{l}\text { Std. Mean Difference (IV, } \\
\text { Random, } 95 \% \text { CI) }\end{array}$ & $-0.15[-0.51,0.21]$ \\
\hline
\end{tabular}

Comparison 9

Total dropouts (any reason)

\begin{tabular}{lcclc}
\hline $\begin{array}{l}\text { Outcome or subgroup } \\
\text { title }\end{array}$ & No. of studies & No. of participants & Statistical method & Effect size \\
\hline $\begin{array}{l}\text { 1 Milnacipran vs } \\
\text { TCAs }\end{array}$ & 6 & 795 & $\begin{array}{l}\text { Odds Ratio (M-H, Random, } \\
95 \% \text { CI) }\end{array}$ & $0.90[0.62,1.33]$ \\
\end{tabular}




\begin{tabular}{|c|c|c|c|c|}
\hline $\begin{array}{l}\text { Outcome or subgroup } \\
\text { title }\end{array}$ & No. of studies & No. of participants & Statistical method & Effect size \\
\hline $\begin{array}{l}\text { 1.1 Milnacipran vs } \\
\text { Imipramine }\end{array}$ & 4 & 562 & $\begin{array}{l}\text { Odds Ratio (M-H, Random, } \\
95 \% \text { CI) }\end{array}$ & $0.88[0.52,1.48]$ \\
\hline $\begin{array}{l}\text { 1.2 Milnacipran vs } \\
\text { Amitriptyline }\end{array}$ & 2 & 233 & $\begin{array}{l}\text { Odds Ratio (M-H, Random, } \\
95 \% \text { CI) }\end{array}$ & $0.97[0.47,1.97]$ \\
\hline $\begin{array}{l}2 \text { Milnacipran vs } \\
\text { SSRIs }\end{array}$ & 8 & 1196 & $\begin{array}{l}\text { Odds Ratio (M-H, Random, } \\
95 \% \text { CI) }\end{array}$ & $0.97[0.74,1.26]$ \\
\hline $\begin{array}{l}\text { 2.1 Milancipran vs } \\
\text { Fluvoxamine }\end{array}$ & 2 & 240 & $\begin{array}{l}\text { Odds Ratio (M-H, Random, } \\
95 \% \text { CI) }\end{array}$ & $0.80[0.42,1.54]$ \\
\hline $\begin{array}{l}2.2 \text { Milancipran vs } \\
\text { Fluoxetine }\end{array}$ & 3 & 560 & $\begin{array}{l}\text { Odds Ratio (M-H, Random, } \\
95 \% \text { CI) }\end{array}$ & $1.02[0.71,1.46]$ \\
\hline $\begin{array}{l}2.3 \text { Milnacipran vs } \\
\text { Paroxetine }\end{array}$ & 2 & 343 & $\begin{array}{l}\text { Odds Ratio (M-H, Random, } \\
95 \% \text { CI) }\end{array}$ & $0.85[0.49,1.48]$ \\
\hline $\begin{array}{l}\text { 2.4 Milancipran vs } \\
\text { Sertraline }\end{array}$ & 1 & 53 & $\begin{array}{l}\text { Odds Ratio (M-H, Random, } \\
95 \% \text { CI) }\end{array}$ & $1.70[0.57,5.05]$ \\
\hline $\begin{array}{l}3 \text { Milnacipran vs } \\
\text { Heterocyclics }\end{array}$ & 1 & 179 & $\begin{array}{l}\text { Odds Ratio (M-H, Random, } \\
95 \% \text { CI) }\end{array}$ & $1.04[0.57,1.87]$ \\
\hline $\begin{array}{l}\text { 3.1 Milacipran vs } \\
\text { Mianserin }\end{array}$ & 1 & 179 & $\begin{array}{l}\text { Odds Ratio (M-H, Random, } \\
95 \% \text { CI) }\end{array}$ & $1.04[0.57,1.87]$ \\
\hline
\end{tabular}

Comparison 10

Dropouts due to inefficacy

\begin{tabular}{|c|c|c|c|c|}
\hline $\begin{array}{l}\text { Outcome or } \\
\text { subgroup title }\end{array}$ & No. of studies & No. of participants & Statistical method & Effect size \\
\hline $\begin{array}{l}1 \text { Milnacipran vs } \\
\text { TCAs }\end{array}$ & 7 & 902 & $\begin{array}{l}\text { Odds Ratio (M-H, Random, } \\
95 \% \text { CI) }\end{array}$ & $1.27[0.82,1.99]$ \\
\hline $\begin{array}{l}\text { 1.1 Milnacipran vs } \\
\text { Imipramine }\end{array}$ & 4 & 562 & $\begin{array}{l}\text { Odds Ratio (M-H, Random, } \\
95 \% \text { CI) }\end{array}$ & $1.14[0.66,1.95]$ \\
\hline $\begin{array}{l}\text { 1.2 Milnacipran vs } \\
\text { Clomipramine }\end{array}$ & 1 & 107 & $\begin{array}{l}\text { Odds Ratio (M-H, Random, } \\
95 \% \text { CI) }\end{array}$ & $3.04[0.89,10.38]$ \\
\hline $\begin{array}{l}\text { 1.3 Milnacipran vs } \\
\text { Amitryptyline }\end{array}$ & 2 & 233 & $\begin{array}{l}\text { Odds Ratio (M-H, Random, } \\
95 \% \text { CI) }\end{array}$ & $1.10[0.42,2.90]$ \\
\hline $\begin{array}{l}2 \text { Milnacipran vs } \\
\text { SSRIs }\end{array}$ & 7 & 1143 & $\begin{array}{l}\text { Odds Ratio (M-H, Random, } \\
95 \% \text { CI) }\end{array}$ & $0.99[0.66,1.48]$ \\
\hline $\begin{array}{l}\text { 2.1 Milnacipran vs } \\
\text { Fluvoxamine }\end{array}$ & 2 & 240 & $\begin{array}{l}\text { Odds Ratio (M-H, Random, } \\
95 \% \text { CI) }\end{array}$ & $1.39[0.53,3.63]$ \\
\hline $\begin{array}{l}2.2 \text { Milnacipran vs } \\
\text { Fluoxetine }\end{array}$ & 3 & 560 & $\begin{array}{l}\text { Odds Ratio (M-H, Random, } \\
95 \% \text { CI) }\end{array}$ & $0.84[0.42,1.70]$ \\
\hline $\begin{array}{l}2.3 \text { Millnacipran vs } \\
\text { Paroxetine }\end{array}$ & 2 & 343 & $\begin{array}{l}\text { Odds Ratio (M-H, Random, } \\
95 \% \text { CI) }\end{array}$ & $1.58[0.55,4.54]$ \\
\hline $\begin{array}{l}3 \text { Milnacipran vs } \\
\text { Heterocyclics }\end{array}$ & 1 & 179 & $\begin{array}{l}\text { Odds Ratio (M-H, Random, } \\
95 \% \text { CI) }\end{array}$ & $0.57[0.22,1.51]$ \\
\hline $\begin{array}{l}\text { 3.1 Milnacipran vs } \\
\text { Mianserin }\end{array}$ & 1 & 179 & $\begin{array}{l}\text { Odds Ratio (M-H, Random, } \\
95 \% \text { CI) }\end{array}$ & $0.57[0.22,1.51]$ \\
\hline
\end{tabular}




\section{Comparison 11}

Dropouts due to adverse events

\begin{tabular}{|c|c|c|c|c|}
\hline $\begin{array}{l}\text { Outcome or subgroup } \\
\text { title }\end{array}$ & No. of studies & No. of participants & Statistical method & Effect size \\
\hline 1 Milnacipran vs TCAs & 6 & 756 & $\begin{array}{l}\text { Odds Ratio (M-H, Random, } \\
95 \% \text { CI) }\end{array}$ & $0.55[0.35,0.85]$ \\
\hline $\begin{array}{l}1.1 \text { Milnacipran vs } \\
\text { Imipramine }\end{array}$ & 4 & 562 & $\begin{array}{l}\text { Odds Ratio (M-H, Random, } \\
95 \% \text { CI) }\end{array}$ & $0.60[0.35,1.04]$ \\
\hline $\begin{array}{l}\text { 1.2 Milnacipran vs } \\
\text { Clomipramine }\end{array}$ & 1 & 107 & $\begin{array}{l}\text { Odds Ratio (M-H, Random, } \\
95 \% \text { CI) }\end{array}$ & $0.43[0.18,1.03]$ \\
\hline $\begin{array}{l}\text { 1.3 Milnacipran vs } \\
\text { Amitriptyline }\end{array}$ & 1 & 87 & $\begin{array}{l}\text { Odds Ratio (M-H, Random, } \\
95 \% \text { CI) }\end{array}$ & $0.56[0.12,2.49]$ \\
\hline 2 Milnacipran vs SSRIs & 7 & 1143 & $\begin{array}{l}\text { Odds Ratio (M-H, Random, } \\
95 \% \text { CI) }\end{array}$ & $0.71[0.48,1.04]$ \\
\hline $\begin{array}{l}2.1 \text { Milnacipran vs } \\
\text { Fluvoxamine }\end{array}$ & 2 & 240 & $\begin{array}{l}\text { Odds Ratio (M-H, Random, } \\
95 \% \text { CI) }\end{array}$ & $0.51[0.17,1.47]$ \\
\hline $\begin{array}{l}2.2 \text { Milnacipran vs } \\
\text { Fluoxetine }\end{array}$ & 3 & 560 & $\begin{array}{l}\text { Odds Ratio (M-H, Random, } \\
95 \% \text { CI) }\end{array}$ & $0.70[0.41,1.19]$ \\
\hline $\begin{array}{l}2.3 \text { Milancipran vs } \\
\text { Paroxetine }\end{array}$ & 2 & 343 & $\begin{array}{l}\text { Odds Ratio (M-H, Random, } \\
\text { 95\% CI) }\end{array}$ & $0.82[0.42,1.62]$ \\
\hline $\begin{array}{l}3 \text { Milnacipran vs } \\
\text { Heterocyclics }\end{array}$ & 1 & 179 & $\begin{array}{l}\text { Odds Ratio (M-H, Random, } \\
95 \% \text { CI) }\end{array}$ & $0.78[0.33,1.87]$ \\
\hline $\begin{array}{l}\text { 3.1 Milnacipran vs } \\
\text { Mianserin }\end{array}$ & 1 & 179 & $\begin{array}{l}\text { Odds Ratio (M-H, Random, } \\
95 \% \text { CI) }\end{array}$ & $0.78[0.33,1.87]$ \\
\hline
\end{tabular}

Comparison 12

Patients with at least some adverse events (Tolerability)

\begin{tabular}{|c|c|c|c|c|}
\hline $\begin{array}{l}\text { Outcome or subgroup } \\
\text { title }\end{array}$ & No. of studies & No. of participants & Statistical method & Effect size \\
\hline $\begin{array}{l}1 \text { Milnacipran vs } \\
\text { TCAs }\end{array}$ & 6 & 795 & $\begin{array}{l}\text { Odds Ratio (M-H, Random, } \\
95 \% \text { CI) }\end{array}$ & $0.35[0.24,0.53]$ \\
\hline $\begin{array}{l}\text { 1.1 Milnacipran vs } \\
\text { Imipramine }\end{array}$ & 4 & 562 & $\begin{array}{l}\text { Odds Ratio (M-H, Random, } \\
\text { 95\% CI) }\end{array}$ & $0.43[0.28,0.66]$ \\
\hline $\begin{array}{l}\text { 1.2 Milnacipran vs } \\
\text { Amitriptyline }\end{array}$ & 2 & 233 & $\begin{array}{l}\text { Odds Ratio (M-H, Random, } \\
95 \% \text { CI) }\end{array}$ & $0.23[0.13,0.40]$ \\
\hline $\begin{array}{l}2 \text { Milnacipran vs } \\
\text { SSRIs }\end{array}$ & 5 & 912 & $\begin{array}{l}\text { Odds Ratio (M-H, Random, } \\
95 \% \text { CI) }\end{array}$ & $0.86[0.55,1.34]$ \\
\hline $\begin{array}{l}\text { 2.1 Milnacipran vs } \\
\text { Fluvoxamine }\end{array}$ & 2 & 240 & $\begin{array}{l}\text { Odds Ratio (M-H, Random, } \\
95 \% \text { CI) }\end{array}$ & $0.51[0.28,0.94]$ \\
\hline $\begin{array}{l}2.2 \text { Milnacipran vs } \\
\text { Fluoxetine }\end{array}$ & 2 & 370 & $\begin{array}{l}\text { Odds Ratio (M-H, Random, } \\
\text { 95\% CI) }\end{array}$ & $0.90[0.49,1.67]$ \\
\hline $\begin{array}{l}2.3 \text { Milnacipran vs } \\
\text { Paroxetine }\end{array}$ & 1 & 302 & $\begin{array}{l}\text { Odds Ratio (M-H, Random, } \\
95 \% \text { CI) }\end{array}$ & $1.45[0.87,2.43]$ \\
\hline $\begin{array}{l}3 \text { Milnacipran vs } \\
\text { Heterocyclics }\end{array}$ & 1 & 179 & $\begin{array}{l}\text { Odds Ratio (M-H, Random, } \\
\text { 95\% CI) }\end{array}$ & $0.62[0.34,1.15]$ \\
\hline $\begin{array}{l}\text { 3.1 Milnacipran vs } \\
\text { Mianserin }\end{array}$ & 1 & 179 & $\begin{array}{l}\text { Odds Ratio (M-H, Random, } \\
95 \% \text { CI) }\end{array}$ & $0.62[0.34,1.15]$ \\
\hline
\end{tabular}


Comparison 13

Adverse events: Sleepiness/ Drowsiness

\begin{tabular}{|c|c|c|c|c|}
\hline $\begin{array}{l}\text { Outcome or subgroup } \\
\text { title }\end{array}$ & No. of studies & No. of participants & Statistical method & Effect size \\
\hline 1 Milnacipran vs TCAs & 5 & 693 & $\begin{array}{l}\text { Odds Ratio (M-H, Random, } \\
95 \% \text { CI) }\end{array}$ & $0.22[0.07,0.73]$ \\
\hline $\begin{array}{l}\text { 1.1 Milancipran vs } \\
\text { Imipramine }\end{array}$ & 2 & 353 & $\begin{array}{l}\text { Odds Ratio (M-H, Random, } \\
95 \% \text { CI) }\end{array}$ & $0.68[0.19,2.45]$ \\
\hline $\begin{array}{l}1.2 \text { Milnacipran vs } \\
\text { Clomipramine }\end{array}$ & 1 & 107 & $\begin{array}{l}\text { Odds Ratio (M-H, Random, } \\
95 \% \text { CI) }\end{array}$ & $0.20[0.01,4.35]$ \\
\hline $\begin{array}{l}\text { 1.3 Milnacipran vs } \\
\text { Amitriptyline }\end{array}$ & 2 & 233 & $\begin{array}{l}\text { Odds Ratio (M-H, Random, } \\
95 \% \text { CI) }\end{array}$ & $0.07[0.02,0.22]$ \\
\hline 2 Milancipran vs SSRIs & 6 & 1102 & $\begin{array}{l}\text { Odds Ratio (M-H, Random, } \\
95 \% \text { CI) }\end{array}$ & $0.56[0.26,1.17]$ \\
\hline $\begin{array}{l}2.1 \text { Milnacipran vs } \\
\text { Fluvoxamine }\end{array}$ & 2 & 240 & $\begin{array}{l}\text { Odds Ratio (M-H, Random, } \\
95 \% \text { CI) }\end{array}$ & $0.43[0.10,1.85]$ \\
\hline $\begin{array}{l}2.2 \text { Milnacipran vs } \\
\text { Fluoxetine }\end{array}$ & 3 & 560 & $\begin{array}{l}\text { Odds Ratio (M-H, Random, } \\
95 \% \text { CI) }\end{array}$ & $0.64[0.15,2.71]$ \\
\hline $\begin{array}{l}2.3 \text { Milnacipran vs } \\
\text { Paroxetine }\end{array}$ & 1 & 302 & $\begin{array}{l}\text { Odds Ratio (M-H, Random, } \\
95 \% \text { CI) }\end{array}$ & $0.51[0.05,5.69]$ \\
\hline $\begin{array}{l}3 \text { Milnacipran vs } \\
\text { Heterocyclics }\end{array}$ & 1 & 179 & $\begin{array}{l}\text { Odds Ratio (M-H, Random, } \\
95 \% \text { CI) }\end{array}$ & $0.21[0.08,0.58]$ \\
\hline $\begin{array}{l}\text { 3.1 Milancipran vs } \\
\text { Mianserin }\end{array}$ & 1 & 179 & $\begin{array}{l}\text { Odds Ratio (M-H, Random, } \\
95 \% \text { CI) }\end{array}$ & $0.21[0.08,0.58]$ \\
\hline
\end{tabular}

Comparison 14

Adverse events: Insomnia

\begin{tabular}{|c|c|c|c|c|}
\hline $\begin{array}{l}\text { Outcome or } \\
\text { subgroup title }\end{array}$ & No. of studies & No. of participants & Statistical method & Effect size \\
\hline $\begin{array}{l}1 \text { Milnacipran vs } \\
\text { TCAs }\end{array}$ & 6 & 756 & $\begin{array}{l}\text { Odds Ratio (M-H, Random, } \\
95 \% \text { CI) }\end{array}$ & $1.12[0.57,2.22]$ \\
\hline $\begin{array}{l}\text { 1.1 Milancipran vs } \\
\text { Imipramine }\end{array}$ & 4 & 562 & $\begin{array}{l}\text { Odds Ratio (M-H, Random, } \\
95 \% \text { CI) }\end{array}$ & $0.86[0.49,1.53]$ \\
\hline $\begin{array}{l}\text { 1.2 Milnacipran vs } \\
\text { Clomipramine }\end{array}$ & 1 & 107 & $\begin{array}{l}\text { Odds Ratio (M-H, Random, } \\
95 \% \text { CI) }\end{array}$ & $5.55[1.14,27.04]$ \\
\hline $\begin{array}{l}\text { 1.3 Milnacipran vs } \\
\text { Amitriptyline }\end{array}$ & 1 & 87 & $\begin{array}{l}\text { Odds Ratio (M-H, Random, } \\
95 \% \text { CI) }\end{array}$ & $1.5[0.24,9.45]$ \\
\hline $\begin{array}{l}2 \text { Milancipran vs } \\
\text { SSRIs }\end{array}$ & 6 & 1102 & $\begin{array}{l}\text { Odds Ratio (M-H, Random, } \\
95 \% \text { CI) }\end{array}$ & $0.51[0.29,0.90]$ \\
\hline $\begin{array}{l}2.1 \text { Milnacipran vs } \\
\text { Fluvoxamine }\end{array}$ & 2 & 240 & $\begin{array}{l}\text { Odds Ratio (M-H, Random, } \\
95 \% \text { CI) }\end{array}$ & $0.73[0.28,1.92]$ \\
\hline $\begin{array}{l}2.2 \text { Milnacipran vs } \\
\text { Fluoxetine }\end{array}$ & 3 & 560 & $\begin{array}{l}\text { Odds Ratio (M-H, Random, } \\
95 \% \text { CI) }\end{array}$ & $0.41[0.20,0.87]$ \\
\hline $\begin{array}{l}2.3 \text { Milnacipran vs } \\
\text { Paroxetine }\end{array}$ & 1 & 302 & $\begin{array}{l}\text { Odds Ratio (M-H, Random, } \\
95 \% \text { CI) }\end{array}$ & $0.51[0.05,5.69]$ \\
\hline $\begin{array}{l}3 \text { Milnacipran vs } \\
\text { Heterocyclics }\end{array}$ & 1 & 179 & $\begin{array}{l}\text { Odds Ratio (M-H, Random, } \\
95 \% \text { CI) }\end{array}$ & $1.13[0.07,18.39]$ \\
\hline $\begin{array}{l}\text { 3.1 Milancipran vs } \\
\text { Mianserin }\end{array}$ & 1 & 179 & $\begin{array}{l}\text { Odds Ratio (M-H, Random, } \\
95 \% \text { CI) }\end{array}$ & $1.13[0.07,18.39]$ \\
\hline
\end{tabular}


Comparison 15

Adverse events: Dro

\begin{tabular}{|c|c|c|c|c|}
\hline $\begin{array}{l}\text { Outcome or subgroup } \\
\text { title }\end{array}$ & No. of studies & No. of participants & Statistical method & Effect size \\
\hline 1 Milnacipran vs TCAs & 7 & 902 & $\begin{array}{l}\text { Odds Ratio (M-H, Random, } \\
95 \% \text { CI) }\end{array}$ & $0.43[0.28,0.65]$ \\
\hline $\begin{array}{l}1.1 \text { Milancipran vs } \\
\text { Imipramine }\end{array}$ & 4 & 562 & $\begin{array}{l}\text { Odds Ratio (M-H, Random, } \\
95 \% \text { CI) }\end{array}$ & $0.57[0.37,0.86]$ \\
\hline $\begin{array}{l}\text { 1.2 Milnacipran vs } \\
\text { Clomipramine }\end{array}$ & 1 & 107 & $\begin{array}{l}\text { Odds Ratio (M-H, Random, } \\
95 \% \text { CI) }\end{array}$ & $0.45[0.21,0.97]$ \\
\hline $\begin{array}{l}\text { 1.3 Milnacipran vs } \\
\text { Amitriptyline }\end{array}$ & 2 & 233 & $\begin{array}{l}\text { Odds Ratio (M-H, Random, } \\
95 \% \text { CI) }\end{array}$ & $0.22[0.12,0.39]$ \\
\hline 2 Milancipran vs SSRIs & 4 & 500 & $\begin{array}{l}\text { Odds Ratio (M-H, Random, } \\
95 \% \text { CI) }\end{array}$ & $1.04[0.60,1.80]$ \\
\hline $\begin{array}{l}\text { 2.1 Milnacipran vs } \\
\text { Fluvoxamine }\end{array}$ & 2 & 240 & $\begin{array}{l}\text { Odds Ratio (M-H, Random, } \\
95 \% \text { CI) }\end{array}$ & $0.87[0.42,1.78]$ \\
\hline $\begin{array}{l}2.2 \text { Milnacipran vs } \\
\text { Fluoxetine }\end{array}$ & 2 & 260 & $\begin{array}{l}\text { Odds Ratio (M-H, Random, } \\
95 \% \text { CI) }\end{array}$ & $1.34[0.58,3.13]$ \\
\hline $\begin{array}{l}3 \text { Milnacipran vs } \\
\text { Heterocyclics }\end{array}$ & 1 & 179 & $\begin{array}{l}\text { Odds Ratio (M-H, Random, } \\
95 \% \text { CI) }\end{array}$ & $0.44[0.15,1.30]$ \\
\hline $\begin{array}{l}\text { 3.1 Milancipran vs } \\
\text { Mianserin }\end{array}$ & 1 & 179 & $\begin{array}{l}\text { Odds Ratio (M-H, Random, } \\
95 \% \text { CI) }\end{array}$ & $0.44[0.15,1.30]$ \\
\hline
\end{tabular}

Comparison 16

Adverse events: Constipation

\begin{tabular}{|c|c|c|c|c|}
\hline $\begin{array}{l}\text { Outcome or subgroup } \\
\text { title }\end{array}$ & No. of studies & No. of participants & Statistical method & Effect size \\
\hline $\begin{array}{l}1 \text { Milnacipran vs } \\
\text { TCAs }\end{array}$ & 6 & 795 & $\begin{array}{l}\text { Odds Ratio (M-H, Random, } \\
95 \% \text { CI) }\end{array}$ & $0.62[0.44,0.88]$ \\
\hline $\begin{array}{l}\text { 1.1 Milancipran vs } \\
\text { Imipramine }\end{array}$ & 4 & 562 & $\begin{array}{l}\text { Odds Ratio (M-H, Random, } \\
95 \% \text { CI) }\end{array}$ & $0.64[0.41,0.98]$ \\
\hline $\begin{array}{l}\text { 1.2 Milnacipran vs } \\
\text { Amitriptyline }\end{array}$ & 2 & 233 & $\begin{array}{l}\text { Odds Ratio (M-H, Random, } \\
95 \% \text { CI) }\end{array}$ & $0.60[0.34,1.06]$ \\
\hline $\begin{array}{l}2 \text { Milancipran vs } \\
\text { SSRIs }\end{array}$ & 5 & 800 & $\begin{array}{l}\text { Odds Ratio (M-H, Random, } \\
95 \% \text { CI) }\end{array}$ & $1.19[0.69,2.06]$ \\
\hline $\begin{array}{l}\text { 2.1 Milnacipran vs } \\
\text { Fluvoxamine }\end{array}$ & 2 & 240 & $\begin{array}{l}\text { Odds Ratio (M-H, Random, } \\
\text { 95\% CI) }\end{array}$ & $1.30[0.28,6.01]$ \\
\hline $\begin{array}{l}2.2 \text { Milnacipran vs } \\
\text { Fluoxetine }\end{array}$ & 3 & 560 & $\begin{array}{l}\text { Odds Ratio (M-H, Random, } \\
95 \% \text { CI) }\end{array}$ & $1.43[0.67,3.06]$ \\
\hline $\begin{array}{l}3 \text { Milnacipran vs } \\
\text { Heterocyclics }\end{array}$ & 1 & 179 & $\begin{array}{l}\text { Odds Ratio (M-H, Random, } \\
95 \% \text { CI) }\end{array}$ & $0.27[0.05,1.29]$ \\
\hline $\begin{array}{l}\text { 3.1 Milancipran vs } \\
\text { Mianserin }\end{array}$ & 1 & 179 & $\begin{array}{l}\text { Odds Ratio (M-H, Random, } \\
95 \% \text { CI) }\end{array}$ & $0.27[0.05,1.29]$ \\
\hline
\end{tabular}




\section{Comparison 17}

Adverse events: Urination problems

\begin{tabular}{|c|c|c|c|c|}
\hline $\begin{array}{l}\text { Outcome or } \\
\text { subgroup title }\end{array}$ & No. of studies & No. of participants & Statistical method & Effect size \\
\hline $\begin{array}{l}1 \text { Milnacipran vs } \\
\text { TCAs }\end{array}$ & 2 & 232 & $\begin{array}{l}\text { Odds Ratio (M-H, Random, } \\
95 \% \text { CI) }\end{array}$ & $1.81[0.57,5.73]$ \\
\hline $\begin{array}{l}1.1 \text { Milancipran vs } \\
\text { Imipramine }\end{array}$ & 2 & 232 & $\begin{array}{l}\text { Odds Ratio (M-H, Random, } \\
95 \% \text { CI) }\end{array}$ & $1.81[0.57,5.73]$ \\
\hline $\begin{array}{l}2 \text { Milancipran vs } \\
\text { SSRIs }\end{array}$ & 4 & 732 & $\begin{array}{l}\text { Odds Ratio (M-H, Random, } \\
95 \% \text { CI) }\end{array}$ & $1.51[0.59,3.90]$ \\
\hline $\begin{array}{l}\text { 2.1 Milnacipran vs } \\
\text { 2 Fluvoxamine }\end{array}$ & 2 & 240 & $\begin{array}{l}\text { Odds Ratio (M-H, Random, } \\
95 \% \text { CI) }\end{array}$ & $1.70[0.39,7.35]$ \\
\hline $\begin{array}{l}2.2 \text { Milnacipran vs } \\
\text { Fluoxetine }\end{array}$ & 1 & 190 & $\begin{array}{l}\text { Odds Ratio (M-H, Random, } \\
95 \% \text { CI) }\end{array}$ & $1.21[0.31,4.65]$ \\
\hline $\begin{array}{l}2.3 \text { Milnacipran vs } \\
\text { Paroxetine }\end{array}$ & 1 & 302 & $\begin{array}{l}\text { Odds Ratio (M-H, Random, } \\
95 \% \text { CI) }\end{array}$ & $3.10[0.13,76.73]$ \\
\hline $\begin{array}{l}3 \text { Milnacipran vs } \\
\text { Heterocyclics }\end{array}$ & 1 & 179 & $\begin{array}{l}\text { Odds Ratio (M-H, Random, } \\
95 \% \text { CI) }\end{array}$ & $2.29[0.20,25.75]$ \\
\hline $\begin{array}{l}\text { 3.1 Milancipran vs } \\
\text { Mianserin }\end{array}$ & 1 & 179 & $\begin{array}{l}\text { Odds Ratio (M-H, Random, } \\
95 \% \mathrm{CI})\end{array}$ & $2.29[0.20,25.75]$ \\
\hline
\end{tabular}

Comparison 18 Adverse events: Hypotention

\begin{tabular}{|c|c|c|c|c|}
\hline $\begin{array}{l}\text { Outcome or } \\
\text { subgroup title }\end{array}$ & No. of studies & No. of participants & Statistical method & Effect size \\
\hline $\begin{array}{l}1 \text { Milnacipran vs } \\
\text { TCAs }\end{array}$ & 5 & 656 & $\begin{array}{l}\text { Odds Ratio (M-H, Random, } \\
95 \% \text { CI) }\end{array}$ & $0.48[0.16,1.45]$ \\
\hline $\begin{array}{l}\text { 1.1 Milancipran vs } \\
\text { Imipramine }\end{array}$ & 3 & 462 & $\begin{array}{l}\text { Odds Ratio (M-H, Random, } \\
95 \% \text { CI) }\end{array}$ & $0.17[0.04,0.76]$ \\
\hline $\begin{array}{l}\text { 1.2 Milnacipran vs } \\
\text { Clomipramine }\end{array}$ & 1 & 107 & $\begin{array}{l}\text { Odds Ratio (M-H, Random, } \\
95 \% \text { CI) }\end{array}$ & $1.64[0.74,3.62]$ \\
\hline $\begin{array}{l}\text { 1.3 Milnacipran vs } \\
\text { Amitriptyline }\end{array}$ & 1 & 87 & $\begin{array}{l}\text { Odds Ratio (M-H, Random, } \\
95 \% \text { CI) }\end{array}$ & $0.41[0.14,1.21]$ \\
\hline $\begin{array}{l}2 \text { Milancipran vs } \\
\text { SSRIs }\end{array}$ & 4 & 687 & $\begin{array}{l}\text { Odds Ratio (M-H, Random, } \\
95 \% \text { CI) }\end{array}$ & $1.50[0.73,3.08]$ \\
\hline $\begin{array}{l}\text { 2.1 Milnacipran vs } \\
\text { Fluvoxamine }\end{array}$ & 1 & 127 & $\begin{array}{l}\text { Odds Ratio (M-H, Random, } \\
95 \% \text { CI) }\end{array}$ & $1.42[0.57,3.53]$ \\
\hline $\begin{array}{l}2.2 \text { Milnacipran vs } \\
\text { Fluoxetine }\end{array}$ & 3 & 560 & $\begin{array}{l}\text { Odds Ratio (M-H, Random, } \\
95 \% \text { CI) }\end{array}$ & $1.51[0.38,5.95]$ \\
\hline $\begin{array}{l}3 \text { Milnacipran vs } \\
\text { Heterocyclics }\end{array}$ & 1 & 179 & $\begin{array}{l}\text { Odds Ratio (M-H, Random, } \\
95 \% \text { CI) }\end{array}$ & $3.43[0.14,85.37]$ \\
\hline $\begin{array}{l}\text { 3.1 Milancipran vs } \\
\text { Mianserin }\end{array}$ & 1 & 179 & $\begin{array}{l}\text { Odds Ratio (M-H, Random, } \\
95 \% \text { CI) }\end{array}$ & $3.43[0.14,85.37]$ \\
\hline
\end{tabular}


Comparison 19

Adverse events: Agitaion/ anxiety

\begin{tabular}{|c|c|c|c|c|}
\hline $\begin{array}{l}\text { Outcome or subgroup } \\
\text { title }\end{array}$ & No. of studies & No. of participants & Statistical method & Effect size \\
\hline $\begin{array}{l}1 \text { Milnacipran vs } \\
\text { TCAs }\end{array}$ & 4 & 549 & $\begin{array}{l}\text { Odds Ratio (M-H, Random, } \\
\text { 95\% CI) }\end{array}$ & $0.64[0.30,1.37]$ \\
\hline $\begin{array}{l}\text { 1.1 Milancipran vs } \\
\text { Imipramine }\end{array}$ & 3 & 462 & $\begin{array}{l}\text { Odds Ratio (M-H, Random, } \\
\text { 95\% CI) }\end{array}$ & $0.66[0.23,1.94]$ \\
\hline $\begin{array}{l}\text { 1.2 Milnacipran vs } \\
\text { Amitriptyline }\end{array}$ & 1 & 87 & $\begin{array}{l}\text { Odds Ratio (M-H, Random, } \\
\text { 95\% CI) }\end{array}$ & $0.62[0.21,1.83]$ \\
\hline $\begin{array}{l}2 \text { Milancipran vs } \\
\text { SSRIs }\end{array}$ & 6 & 1102 & $\begin{array}{l}\text { Odds Ratio (M-H, Random, } \\
95 \% \text { CI) }\end{array}$ & $0.70[0.37,1.30]$ \\
\hline $\begin{array}{l}2.1 \text { Milnacipran vs } \\
\text { Fluvoxamine }\end{array}$ & 2 & 240 & $\begin{array}{l}\text { Odds Ratio (M-H, Random, } \\
95 \% \text { CI) }\end{array}$ & $0.55[0.10,3.04]$ \\
\hline $\begin{array}{l}2.2 \text { Milnacipran vs } \\
\text { Fluoxetine }\end{array}$ & 3 & 560 & $\begin{array}{l}\text { Odds Ratio (M-H, Random, } \\
\text { 95\% CI) }\end{array}$ & $0.82[0.43,1.56]$ \\
\hline $\begin{array}{l}2.3 \text { Milnacipran vs } \\
\text { Paroxetine }\end{array}$ & 1 & 302 & $\begin{array}{l}\text { Odds Ratio (M-H, Random, } \\
\text { 95\% CI) }\end{array}$ & $1.38[0.30,6.27]$ \\
\hline $\begin{array}{l}3 \text { Milnacipran vs } \\
\text { Heterocyclics }\end{array}$ & 1 & 179 & $\begin{array}{l}\text { Odds Ratio (M-H, Random, } \\
95 \% \text { CI) }\end{array}$ & $0.37[0.01,9.27]$ \\
\hline $\begin{array}{l}\text { 3.1 Milancipran vs } \\
\text { Mianserin }\end{array}$ & 1 & 179 & $\begin{array}{l}\text { Odds Ratio (M-H, Random, } \\
\text { 95\% CI) }\end{array}$ & $0.37[0.01,9.27]$ \\
\hline
\end{tabular}

Comparison 20

Adverse events: Suicide wishes/gestures/ attempts

\begin{tabular}{lcclr}
\hline $\begin{array}{l}\text { Outcome or subgroup } \\
\text { title }\end{array}$ & No. of studies & No. of participants & Statistical method & Effect size \\
\hline 1 Milnacipran vs TCAs & 1 & 107 & $\begin{array}{l}\text { Odds Ratio (M-H, Random, } \\
95 \% \text { CI) }\end{array}$ & $0.51[0.09,2.91]$ \\
$\begin{array}{l}1.1 \text { Milnacipran vs } \\
\text { Clomipramine }\end{array}$ & 1 & 107 & $\begin{array}{l}\text { Odds Ratio (M-H, Random, } \\
95 \% \text { CI) }\end{array}$ & $0.51[0.09,2.91]$ \\
2 Milancipran vs SSRIs & 1 & 300 & $\begin{array}{l}\text { Odds Ratio (M-H, Random, } \\
95 \% \text { CI) }\end{array}$ & $0.49[0.14,1.72]$ \\
$\begin{array}{l}\text { 2.1 Milnacipran vs } \\
\text { Fluoxetine }\end{array}$ & 1 & 300 & $\begin{array}{l}\text { Odds Ratio (M-H, Random, } \\
95 \% \text { CI) }\end{array}$ & $0.49[0.14,1.72]$ \\
\hline
\end{tabular}

Comparison 21

Adverse events:Completed suicide

\begin{tabular}{lcclr}
\hline $\begin{array}{l}\text { Outcome or subgroup } \\
\text { title }\end{array}$ & No. of studies & No. of participants & Statistical method & Effect size \\
\hline $\begin{array}{l}\text { 1 Milancipran vs } \\
\text { SSRIs }\end{array}$ & 1 & 300 & $\begin{array}{l}\text { Odds Ratio (M-H, Random, } \\
95 \% \text { CI) }\end{array}$ & $1.0[0.09,11.16]$ \\
$\begin{array}{l}\text { 1.1 Milnacipran vs } \\
\text { Fluoxetine }\end{array}$ & 1 & 300 & $\begin{array}{l}\text { Odds Ratio (M-H, Random, } \\
95 \% \text { CI) }\end{array}$ & $1.0[0.09,11.16]$ \\
\hline
\end{tabular}


Comparison 22

Adverse events: Vomitting/ nausea

\begin{tabular}{|c|c|c|c|c|}
\hline $\begin{array}{l}\text { Outcome or } \\
\text { subgroup title }\end{array}$ & No. of studies & No. of participants & Statistical method & Effect size \\
\hline $\begin{array}{l}1 \text { Milnacipran vs } \\
\text { TCAs }\end{array}$ & 6 & 756 & $\begin{array}{l}\text { Odds Ratio (M-H, Random, } \\
95 \% \text { CI) }\end{array}$ & $2.44[1.34,4.42]$ \\
\hline $\begin{array}{l}\text { 1.1 Milancipran vs } \\
\text { Imipramine }\end{array}$ & 4 & 562 & $\begin{array}{l}\text { Odds Ratio (M-H, Random, } \\
95 \% \text { CI) }\end{array}$ & $2.31[1.13,4.72]$ \\
\hline $\begin{array}{l}\text { 1.2 Milnacipran vs } \\
\text { Clomipramine }\end{array}$ & 1 & 107 & $\begin{array}{l}\text { Odds Ratio (M-H, Random, } \\
95 \% \text { CI) }\end{array}$ & $10.30[0.54,196.19]$ \\
\hline $\begin{array}{l}\text { 1.3 Milnacipran vs } \\
\text { Amitriptyline }\end{array}$ & 1 & 87 & $\begin{array}{l}\text { Odds Ratio (M-H, Random, } \\
95 \% \text { CI) }\end{array}$ & $2.24[0.69,7.19]$ \\
\hline $\begin{array}{l}2 \text { Milancipran vs } \\
\text { SSRIs }\end{array}$ & 6 & 1102 & $\begin{array}{l}\text { Odds Ratio (M-H, Random, } \\
95 \% \text { CI) }\end{array}$ & $0.73[0.42,1.27]$ \\
\hline $\begin{array}{l}\text { 2.1 Milnacipran vs } \\
\text { Fluvoxamine }\end{array}$ & 2 & 240 & $\begin{array}{l}\text { Odds Ratio (M-H, Random, } \\
95 \% \text { CI) }\end{array}$ & $0.51[0.28,0.94]$ \\
\hline $\begin{array}{l}2.2 \text { Milnacipran vs } \\
\text { Fluoxetine }\end{array}$ & 3 & 560 & $\begin{array}{l}\text { Odds Ratio (M-H, Random, } \\
95 \% \text { CI) }\end{array}$ & $1.12[0.36,3.44]$ \\
\hline $\begin{array}{l}2.3 \text { Milnacipran vs } \\
\text { Paroxetine }\end{array}$ & 1 & 302 & $\begin{array}{l}\text { Odds Ratio (M-H, Random, } \\
95 \% \text { CI) }\end{array}$ & $1.03[0.06,16.57]$ \\
\hline $\begin{array}{l}3 \text { Milnacipran vs } \\
\text { Heterocyclics }\end{array}$ & 1 & 179 & $\begin{array}{l}\text { Odds Ratio (M-H, Random, } \\
95 \% \text { CI) }\end{array}$ & $5.95[0.68,51.99]$ \\
\hline $\begin{array}{l}3.1 \text { Milancipran vs } \\
\text { Mianserin }\end{array}$ & 1 & 179 & $\begin{array}{l}\text { Odds Ratio (M-H, Random, } \\
95 \% \text { CI) }\end{array}$ & $5.95[0.68,51.99]$ \\
\hline
\end{tabular}

Comparison 23

Adverse events: Diarrhoea

\begin{tabular}{|c|c|c|c|c|}
\hline $\begin{array}{l}\text { Outcome or } \\
\text { subgroup title }\end{array}$ & No. of studies & No. of participants & Statistical method & Effect size \\
\hline $\begin{array}{l}1 \text { Milnacipran vs } \\
\text { TCAs }\end{array}$ & 5 & 656 & $\begin{array}{l}\text { Odds Ratio (M-H, Random, } \\
95 \% \text { CI) }\end{array}$ & $1.24[0.29,5.29]$ \\
\hline $\begin{array}{l}\text { 1.1 Milancipran vs } \\
\text { Imipramine }\end{array}$ & 3 & 462 & $\begin{array}{l}\text { Odds Ratio (M-H, Random, } \\
95 \% \text { CI) }\end{array}$ & $0.47[0.12,1.75]$ \\
\hline $\begin{array}{l}\text { 1.2 Milnacipran vs } \\
\text { Clomipramine }\end{array}$ & 1 & 107 & $\begin{array}{l}\text { Odds Ratio (M-H, Random, } \\
95 \% \text { CI) }\end{array}$ & $5.50[0.26,117.22]$ \\
\hline $\begin{array}{l}\text { 1.3 Milnacipran vs } \\
\text { Amitriptyline }\end{array}$ & 1 & 87 & $\begin{array}{l}\text { Odds Ratio (M-H, Random, } \\
95 \% \text { CI) }\end{array}$ & $7.34[0.37,146.43]$ \\
\hline $\begin{array}{l}2 \text { Milancipran vs } \\
\text { SSRIs }\end{array}$ & 6 & 1102 & $\begin{array}{l}\text { Odds Ratio (M-H, Random, } \\
95 \% \text { CI) }\end{array}$ & $0.69[0.37,1.27]$ \\
\hline $\begin{array}{l}\text { 2.1 Milnacipran vs } \\
\text { Fluvoxamine }\end{array}$ & 2 & 240 & $\begin{array}{l}\text { Odds Ratio (M-H, Random, } \\
95 \% \text { CI) }\end{array}$ & $0.76[0.29,2.00]$ \\
\hline $\begin{array}{l}2.2 \text { Milnacipran vs } \\
\text { Fluoxetine }\end{array}$ & 3 & 560 & $\begin{array}{l}\text { Odds Ratio (M-H, Random, } \\
95 \% \text { CI) }\end{array}$ & $0.70[0.31,1.58]$ \\
\hline $\begin{array}{l}2.3 \text { Milnacipran vs } \\
\text { Paroxetine }\end{array}$ & 1 & 302 & $\begin{array}{l}\text { Odds Ratio (M-H, Random, } \\
95 \% \text { CI) }\end{array}$ & $0.20[0.01,4.26]$ \\
\hline
\end{tabular}


Comparison 24

Subgroup analysis: Response at early phase (1-4 weeks)-High dose milnacipran

\begin{tabular}{lcclr}
\hline $\begin{array}{l}\text { Outcome or subgroup } \\
\text { title }\end{array}$ & No. of studies & No. of participants & Statistical method & Effect size \\
\hline 1 vs TCAs & 2 & 194 & $\begin{array}{l}\text { Risk Ratio (M-H, Random, } \\
95 \% \text { CI) }\end{array}$ & $0.69[0.42,1.12]$ \\
1.1 vs Clomipramine & 1 & 107 & $\begin{array}{l}\text { Risk Ratio (M-H, Random, } \\
95 \% \text { CI) }\end{array}$ & $0.53[0.23,1.21]$ \\
1.2 vs Amitryptyline & 1 & 87 & $\begin{array}{l}\text { Risk Ratio (M-H, Random, } \\
95 \% \text { CI) }\end{array}$ & $0.79[0.44,1.45]$ \\
\hline
\end{tabular}

Comparison 25

Subgroup analysis: Response at acute phase (6-12

weeks)-Flexible dosing

\begin{tabular}{|c|c|c|c|c|}
\hline $\begin{array}{l}\text { Outcome or subgroup } \\
\text { title }\end{array}$ & No. of studies & No. of participants & Statistical method & Effect size \\
\hline 1 Milnacipran vs TCAs & 2 & 328 & $\begin{array}{l}\text { Odds Ratio (M-H, Random, } \\
95 \% \text { CI) }\end{array}$ & $0.72[0.32,1.63]$ \\
\hline $\begin{array}{l}\text { 1.1 Milnacipran vs } \\
\text { Imipramine }\end{array}$ & 1 & 221 & $\begin{array}{l}\text { Odds Ratio (M-H, Random, } \\
95 \% \text { CI) }\end{array}$ & $1.05[0.61,1.79]$ \\
\hline $\begin{array}{l}\text { 1.2 Milancipran vs } \\
\text { Clomipramine }\end{array}$ & 1 & 107 & $\begin{array}{l}\text { Odds Ratio (M-H, Random, } \\
95 \% \text { CI) }\end{array}$ & $0.45[0.21,0.98]$ \\
\hline
\end{tabular}

Comparison 26

Subgroup analysis: Response at early phase (1-4 weeks)-Flexible dosing

\begin{tabular}{|c|c|c|c|c|}
\hline $\begin{array}{l}\text { Outcome or subgroup } \\
\text { title }\end{array}$ & No. of studies & No. of participants & Statistical method & Effect size \\
\hline 1 Milnacipran vs TCAs & 3 & 460 & $\begin{array}{l}\text { Odds Ratio (M-H, Random, } \\
95 \% \text { CI) }\end{array}$ & $1.03[0.55,1.92]$ \\
\hline $\begin{array}{l}\text { 1.1 Milancipran vs } \\
\text { Imipramine }\end{array}$ & 2 & 353 & $\begin{array}{l}\text { Odds Ratio (M-H, Random, } \\
95 \% \text { CI) }\end{array}$ & $1.35[0.82,2.21]$ \\
\hline $\begin{array}{l}\text { 1.2 Milnacipran vs } \\
\text { Clomipramine }\end{array}$ & 1 & 107 & $\begin{array}{l}\text { Odds Ratio (M-H, Random, } \\
95 \% \text { CI) }\end{array}$ & $0.46[0.17,1.24]$ \\
\hline
\end{tabular}

Comparison 27

Subgroup analysis: Response at acute phase [6-12 weeks]-Outpatient

\begin{tabular}{lcclc}
\hline $\begin{array}{l}\text { Outcome or } \\
\text { subgroup title }\end{array}$ & No. of studies & No. of participants & Statistical method & Effect size \\
\hline $\begin{array}{l}\text { 1 Milnacipran vs } \\
\text { SSRIs }\end{array}$ & 4 & 615 & $\begin{array}{l}\text { Risk Ratio (M-H, Random, 95\% } \\
\text { CI) }\end{array}$ & $0.99[0.72,1.36]$
\end{tabular}




\begin{tabular}{|c|c|c|c|c|}
\hline $\begin{array}{l}\text { Outcome or } \\
\text { subgroup title }\end{array}$ & No. of studies & No. of participants & Statistical method & Effect size \\
\hline $\begin{array}{l}\text { 1.1 Milnacipran vs } \\
\text { Fluoxetine }\end{array}$ & 2 & 260 & $\begin{array}{l}\text { Risk Ratio (M-H, Random, 95\% } \\
\text { CI) }\end{array}$ & $0.89[0.53,1.50]$ \\
\hline $\begin{array}{l}1.2 \text { Milnacipran vs } \\
\text { Paroxetine }\end{array}$ & 1 & 302 & $\begin{array}{l}\text { Risk Ratio (M-H, Random, } 95 \% \\
\text { CI) }\end{array}$ & $0.97[0.80,1.17]$ \\
\hline $\begin{array}{l}\text { 1.3 Milnacipran vs } \\
\text { Sertraline }\end{array}$ & 1 & 53 & $\begin{array}{l}\text { Risk Ratio (M-H, Random, 95\% } \\
\text { CI) }\end{array}$ & $2.89[0.88,9.50]$ \\
\hline
\end{tabular}

Comparison 28

Subgroup analysis: Response at early phase [1-4 weeks]-Outpatient

\begin{tabular}{|c|c|c|c|c|}
\hline $\begin{array}{l}\text { Outcome or } \\
\text { subgroup title }\end{array}$ & No. of studies & No. of participants & Statistical method & Effect size \\
\hline $\begin{array}{l}1 \text { Milancipran vs } \\
\text { SSRIs }\end{array}$ & 2 & 372 & $\begin{array}{l}\text { Risk Ratio (M-H, Random, 95\% } \\
\text { CI) }\end{array}$ & $1.06[0.73,1.52]$ \\
\hline $\begin{array}{l}\text { 1.1 Milnacipran vs } \\
\text { Fluoxetine }\end{array}$ & 1 & 70 & $\begin{array}{l}\text { Risk Ratio (M-H, Random, } 95 \% \\
\text { CI) }\end{array}$ & $1.06[0.41,2.73]$ \\
\hline $\begin{array}{l}1.2 \text { Milnacipran vs } \\
\text { Paroxetine }\end{array}$ & 1 & 302 & $\begin{array}{l}\text { Risk Ratio (M-H, Random, 95\% } \\
\text { CI) }\end{array}$ & $1.05[0.71,1.56]$ \\
\hline
\end{tabular}

Comparison 29

Subgroup analysis: Response at early phase [1-4 weeks]-Inpatient

\begin{tabular}{|c|c|c|c|c|}
\hline $\begin{array}{l}\text { Outcome or subgroup } \\
\text { title }\end{array}$ & No. of studies & No. of participants & Statistical method & Effect size \\
\hline 1 Milnacipran vs TCAs & 3 & 342 & $\begin{array}{l}\text { Risk Ratio (M-H, Random, } 95 \% \\
\text { CI) }\end{array}$ & $0.78[0.60,1.01]$ \\
\hline $\begin{array}{l}\text { 1.1 Milancipran vs } \\
\text { Imipramine }\end{array}$ & 1 & 109 & $\begin{array}{l}\text { Risk Ratio (M-H, Random, } 95 \% \\
\text { CI) }\end{array}$ & $0.85[0.58,1.24]$ \\
\hline $\begin{array}{l}\text { 1.2 Milnacipran vs } \\
\text { Amitriptyline }\end{array}$ & 2 & 233 & $\begin{array}{l}\text { Risk Ratio (M-H, Random, 95\% } \\
\text { CI) }\end{array}$ & $0.73[0.51,1.04]$ \\
\hline $\begin{array}{l}2 \text { Milancipran vs } \\
\text { SSRIs }\end{array}$ & 3 & 468 & $\begin{array}{l}\text { Risk Ratio (M-H, Random, } 95 \% \\
\text { CI) }\end{array}$ & $1.20[0.86,1.69]$ \\
\hline $\begin{array}{l}\text { 2.1 Milnacipran vs } \\
\text { Fluvoxamine }\end{array}$ & 1 & 127 & $\begin{array}{l}\text { Risk Ratio (M-H, Random, } 95 \% \\
\text { CI) }\end{array}$ & $1.53[0.83,2.79]$ \\
\hline $\begin{array}{l}2.2 \text { Milnacipran vs } \\
\text { Fluoxetine }\end{array}$ & 1 & 300 & $\begin{array}{l}\text { Risk Ratio (M-H, Random, 95\% } \\
\text { CI) }\end{array}$ & $1.34[0.96,1.87]$ \\
\hline $\begin{array}{l}\text { 2.3 Milnacipran vs } \\
\text { Paroxetine }\end{array}$ & 1 & 41 & $\begin{array}{l}\text { Risk Ratio (M-H, Random, 95\% } \\
\text { CI) }\end{array}$ & $0.81[0.47,1.40]$ \\
\hline
\end{tabular}


Comparison 30

Subgroup analysis: Response at acute phase [6-12 weeks]-Inpatient

\begin{tabular}{lcclll}
\hline $\begin{array}{l}\text { Outcome or subgroup } \\
\text { title }\end{array}$ & No. of studies & No. of participants & Statistical method & Effect size \\
\hline 1 Milnacipran vs TCAs & 2 & 209 & $\begin{array}{l}\text { Risk Ratio (M-H, Random, 95\% } \\
\text { CI) }\end{array}$ & $1.03[0.81,1.31]$ \\
$\begin{array}{l}\text { 1.1 Milnacipran vs } \\
\text { Imipramine }\end{array}$ & 2 & 209 & $\begin{array}{l}\text { Risk Ratio (M-H, Random, 95\% } \\
\text { CI) }\end{array}$ & $1.03[0.81,1.31]$ \\
\hline
\end{tabular}

\section{Analysis 1.1}

Comparison 1 Response at acute phase (6-12 weeks), Outcome 1 Milnacipran vs TCAs

Review: Milnacipran versus other antidepressive agents for depression Comparison: 1 Response at acute phase (6-12 weeks) Outcome: 1 Milnacipran vs TCAs

\begin{tabular}{|c|c|c|c|c|c|}
\hline Study or subgraup & Minasipran & $\begin{array}{l}\text { TCAS } \\
\text { DAN } \\
\end{array}$ & $\begin{array}{c}\text { Odds Ratio } \\
\text { M- } \\
\text { H.Fandomig\% } \\
\end{array}$ & Weight & $\begin{array}{l}\text { Odds Fatio } \\
\text { H,Random-95\% } \\
\qquad \mathrm{Cl}\end{array}$ \\
\hline \multicolumn{6}{|l|}{ I Minazipran vis Iripramine } \\
\hline Lopez-Hor 2004 & 20,51 & 20149 & $\rightarrow$ & $20.2 \%$ & $0.94[0.42,2.08]$ \\
\hline Tignol l999 & $67 / 112$ & $64 / 109$ & 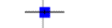 & $37.4 \%$ & $1.05[0.51,1.79]$ \\
\hline $\operatorname{Van}$ Amerongen 2002 & $35 / 53$ & 35,56 & $\longrightarrow$ & $20.9 \%$ & $1.17[0.53,256]$ \\
\hline Subtotal $(95 \% \mathrm{CI})$ & 216 & 214 & - & $78.6 \%$ & $1.05[0.71,1.54]$ \\
\hline \multicolumn{6}{|c|}{ Total exents: 122 (Miracipran). 119 (TCAs) } \\
\hline \multicolumn{6}{|c|}{ Heterogenety: $\operatorname{Tau}^{2}=0.0 ; \mathrm{Ch}^{2}=0.15, \mathrm{df}=2(\mathrm{P}=0.93) ; \mathrm{l}^{2}=0.0 \%$} \\
\hline \multicolumn{6}{|c|}{ Test for overal effect: $Z=0.23(p=0.82)$} \\
\hline \multicolumn{6}{|c|}{2 Milancipran vs Clomipramine } \\
\hline Leinonen 1997 & 22152 & 34,55 & & $21.4 \%$ & $0.45[0.21,0.98]$ \\
\hline Subtotal $(95 \% \mathrm{CI})$ & 52 & 55 & & $21.4 \%$ & $0.45[0.21,0.98]$ \\
\hline \multicolumn{6}{|c|}{ Total events: 22 (Milhacipron), 34 (TCAs) } \\
\hline \multicolumn{6}{|c|}{ Heterogenety: not appicicable } \\
\hline \multicolumn{6}{|c|}{ Test for overal effect: $Z=201(P=0.045)$} \\
\hline Total $(95 \% \mathrm{CI})$ & 268 & 269 & & $100.0 \%$ & $0.87[0.59,1.30]$ \\
\hline \multicolumn{6}{|c|}{ Total events: 144 (Minscipran), i5s (TCAs) } \\
\hline \multicolumn{6}{|c|}{ Heterogenety: $\operatorname{Tau}^{2}=0.03: \mathrm{Ch}^{2}=3.75$, of $=3(\mathrm{P}=0.29) ; \mathrm{i}^{2}=20 \%$} \\
\hline Test for overal effect: $Z=$ & $=0.51)$ & & & & \\
\hline & & & \begin{tabular}{c|cc}
0.5 & 2 & 5 \\
Tas & farvers
\end{tabular} & & \\
\hline
\end{tabular}




\section{Analysis 1.2}

Comparison 1 Response at acute phase (6-12 weeks),

\section{Outcome 2 Milnacipran vs SSRIs}

Review: Milnacipran versus other antidepressive agents for depression Comparison: 1 Response at acute phase (6-12 weeks) Outcome: 2 Milnacipran vs SSRIs

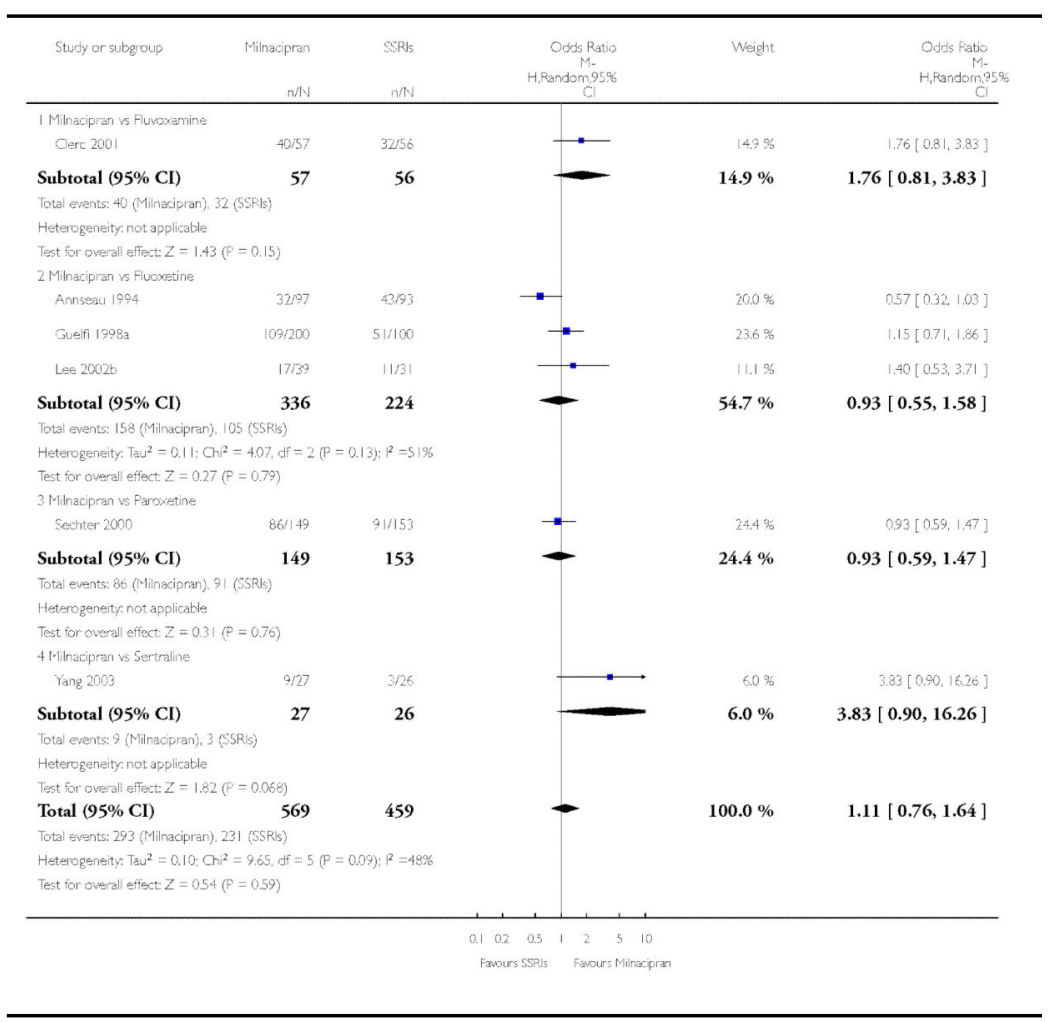




\section{Analysis 2.1}

Comparison 2 Response at early phase (1-4 weeks), Outcome 1 Milnacipran vs TCAs

Review: Milnacipran versus other antidepressive agents for depression Comparison: 2 Response at acute phase (1-4 weeks) Outcome: 1 Milnacipran vs TCAs

\begin{tabular}{|c|c|c|c|c|c|}
\hline Study or subgroup & $\begin{array}{r}\text { Milinacipran } \\
\text { n/N }\end{array}$ & $\begin{array}{l}\text { TCAS } \\
\text { NIN } \\
\end{array}$ & $\begin{array}{c}\text { Odeds Ratio } \\
\text { M- } \\
\text { H.Ranidom } 95 \% \\
\mathrm{CI}\end{array}$ & Weight & $\begin{array}{l}\text { Odde Rato } \\
\text { M. } \\
\text { H.Pandom } 95 \% \\
\mathrm{GI}\end{array}$ \\
\hline \multicolumn{6}{|l|}{1 Milancipran sa mipraming } \\
\hline Tignol 1998 & 231112 & $16 / 109$ & - & $19.4 \%$ & $1.50[0.75,3.03]$ \\
\hline Van Amerongen 2002 & 2453 & 30156 & & $17.5 \%$ & $0.72[0.34,1.52]$ \\
\hline Yamastita 1995 & $20 \% 6$ & $25 / 66$ & $=$ & $19.6 \%$ & $1.21[0.60,2.43]$ \\
\hline Subtotal $(95 \% \mathrm{CI})$ & 231 & 231 & - & $56.5 \%$ & $1.11[0.73,1.69]$ \\
\hline \multicolumn{6}{|c|}{ Total events: 75 (Minaripran), $71,\left(T C \mathrm{As}_{\mathrm{S}}\right\rangle$} \\
\hline \multicolumn{6}{|c|}{ 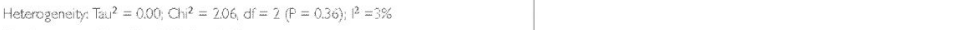 } \\
\hline \multicolumn{6}{|c|}{ Test for wereal effect: $Z=0.50(P=0.52)$} \\
\hline \multicolumn{6}{|c|}{2 Minacipran vs Comipramine } \\
\hline Lanoren 1997 & $7 / 52$ & $14 / 55$ & & $11.1 \%$ & $0.46[0.17,1.24]$ \\
\hline Subtotal $(95 \% \mathrm{CI})$ & 52 & 55 & & $11.1 \%$ & $0.46[0.17,1.24]$ \\
\hline \multicolumn{6}{|c|}{ Tota events: 7 (ITilinacipran), 14 (TCAs) } \\
\hline \multicolumn{6}{|c|}{ Hetercgeneity not applicats } \\
\hline \multicolumn{6}{|c|}{ Test for overall effect: $Z=1.54(P=0.12)$} \\
\hline \multicolumn{6}{|c|}{3 Minacipran ys Amitrintyline } \\
\hline Annseau 198\%a & 29,97 & $21 / 49$ & $=$ & $19.0 \%$ & $0.57[0.281 .16]$ \\
\hline Antseau $1989 \mathrm{c}$ & $13 / 44$ & $16 / 43$ & $\rightarrow$ & $13.4 \%$ & $0.71[0.29,1.73]$ \\
\hline Subtotal $(95 \% \mathrm{CI})$ & 141 & 92 & & $32.3 \%$ & $0.62[0.35,1.08]$ \\
\hline \multicolumn{6}{|c|}{ Total events: 42 (Minacip rar), $37\left(C C_{A}\right)$} \\
\hline \multicolumn{6}{|c|}{ 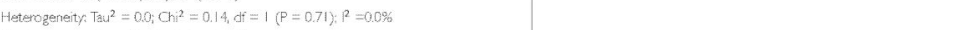 } \\
\hline \multicolumn{6}{|c|}{ Test for overall effect: $Z=1.68(P=0.092)$} \\
\hline Total $(95 \% \mathrm{CI})$ & 424 & 378 & & $100.0 \%$ & $0.83[0.58,1.20]$ \\
\hline \multicolumn{6}{|c|}{ Tota events: 124 (Milhatipranj, 122 (CAs) } \\
\hline \multicolumn{6}{|c|}{ Heterogeneity; $\mathrm{Ta}^{2}=0.05: \mathrm{Ch}^{2}=6.58 \mathrm{df}=5(\mathrm{p}=0.25): \mathrm{l}^{2}=24 \%$} \\
\hline \multicolumn{6}{|c|}{ Tsst for overall effect: $Z=0.98(\rho=0.33)$} \\
\hline & & & 0.20 .5 & & \\
\hline
\end{tabular}




\section{Analysis 2.2}

Comparison 2 Response at early phase (1-4 weeks), Outcome 2 Milancipran vs SSRIs

Review: Milnacipran versus other antidepressive agents for depression Comparison: 2 Response at early phase (1-4 weeks)

Outcome: 2 Milancipran vs SSRIs

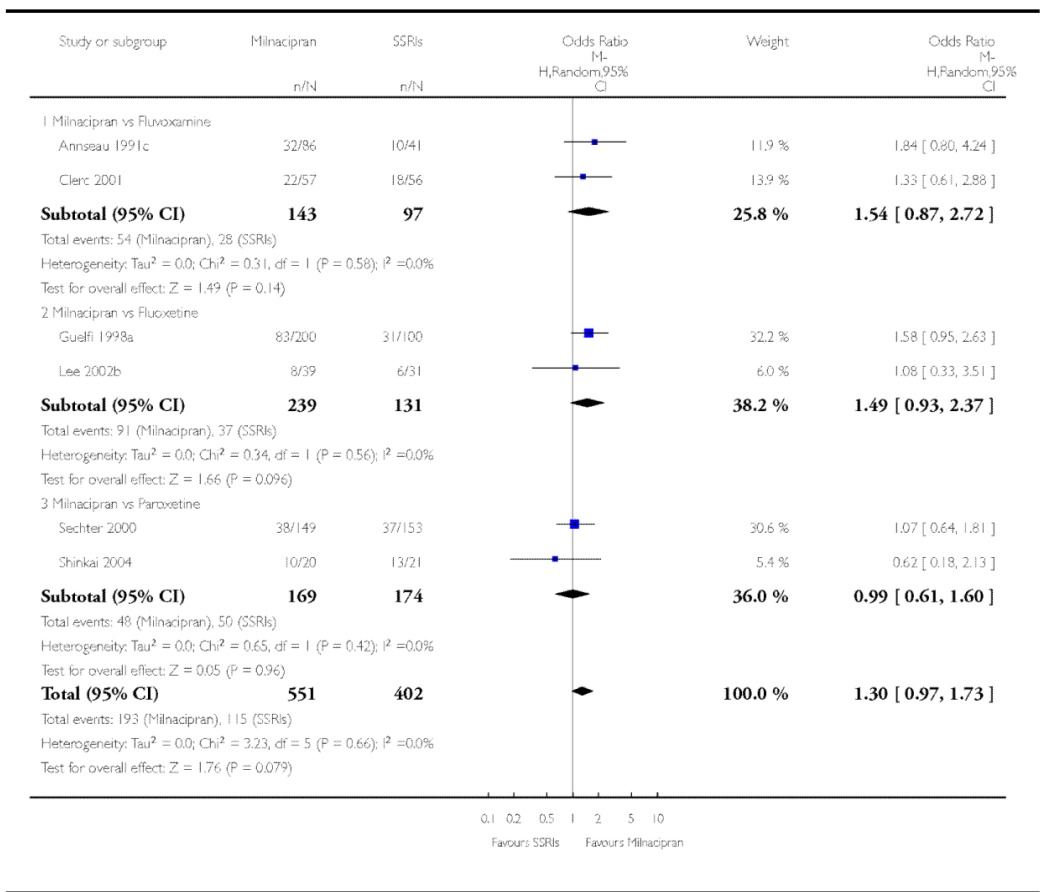

\section{Analysis $\mathbf{2 . 3}$}

Comparison 2 Response at early phase (1-4 weeks), Outcome 3 Milnacipran vs Heterocyclics

Review: Milnacipran versus other antidepressive agents for depression Comparison: 2 Response at early phase (1-4 weeks)

Outcome: 3 Milnacipran vs Heterocyclics

\begin{tabular}{|c|c|c|c|c|c|}
\hline Study or subgroup & $\begin{array}{r}\text { Minacipran } \\
\text { not/N }\end{array}$ & $\begin{array}{l}\text { Heterocydics } \\
\text { niN }\end{array}$ & $\begin{array}{c}\text { Odds Ratio } \\
11 \\
\text { HRandom } 95 \% \\
\end{array}$ & Weight & $\begin{array}{c}\text { Odds Rutio } \\
\text { 1. } \\
\text { HRencom } 95 \% \\
\square\end{array}$ \\
\hline \multicolumn{6}{|c|}{1 Milancipran ys Mianserin } \\
\hline Endo 1995 & $19 / 84$ & $20 / 95$ & t- & $1000 \%$ & $1.10[0.54,2.23]$ \\
\hline Total $(95 \% \mathrm{CI})$ & 84 & 95 & - & $100.0 \%$ & $1.10[0.54,2.23]$ \\
\hline \multicolumn{6}{|c|}{ Totsl events 19 (Milharipran), 20 (Heterocydilis) } \\
\hline \multicolumn{6}{|c|}{ Heterogenenety not appilicable } \\
\hline Test for overal effect & $25(p=0.80)$ & & & & \\
\hline
\end{tabular}


Analysis 3.1

Comparison 3 Response at follow-up phase (4-6 months), Outcome 1 Milnacipran vs TCAs

Review: Milnacipran versus other antidepressive agents for depression Comparison: 3 Response at follow-up phase (4-6 months)

Outcome: 1 Milnacipran vs TCAs

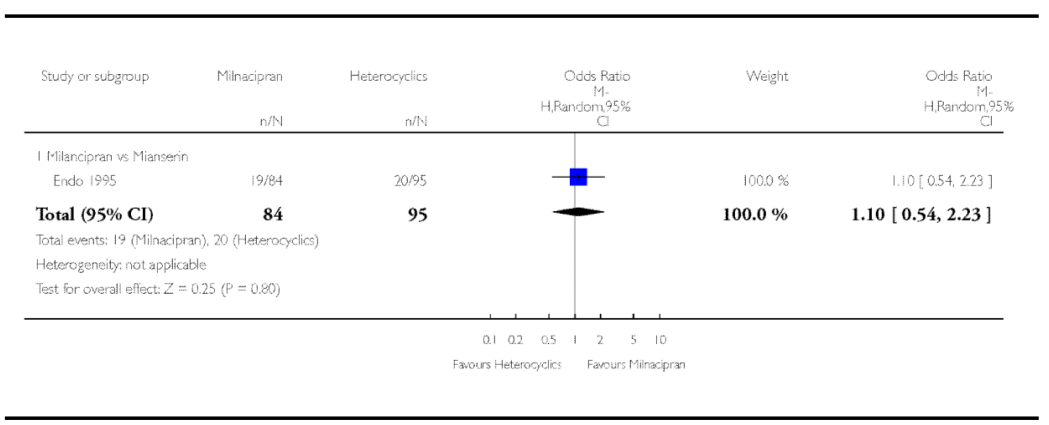

Analysis 4.1

Comparison 4 Remission at acute phase (6-12 weeks), Outcome 1 Milnacipran vs TCAs

Review: Milnacipran versus other antidepressive agents for depression Comparison: 4 Remission at acute phase (6-12 weeks)

Outcome: 1 Milnacipran vs TCAs

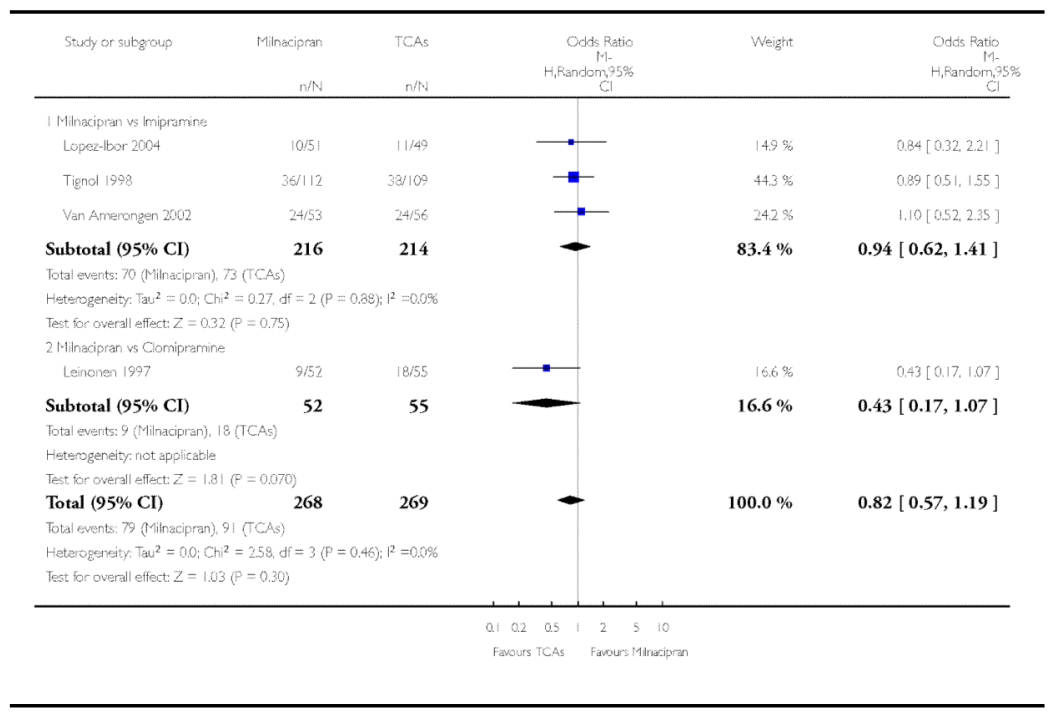


Analysis 4.2

Comparison 4 Remission at acute phase (6-12 weeks), Outcome 2 Milnacipran vs SSRIs

Review: Milnacipran versus other antidepressive agents for depression Comparison: 4 Remission at acute phase (6-12 weeks)

Outcome: 2 Milnacipran vs SSRIs

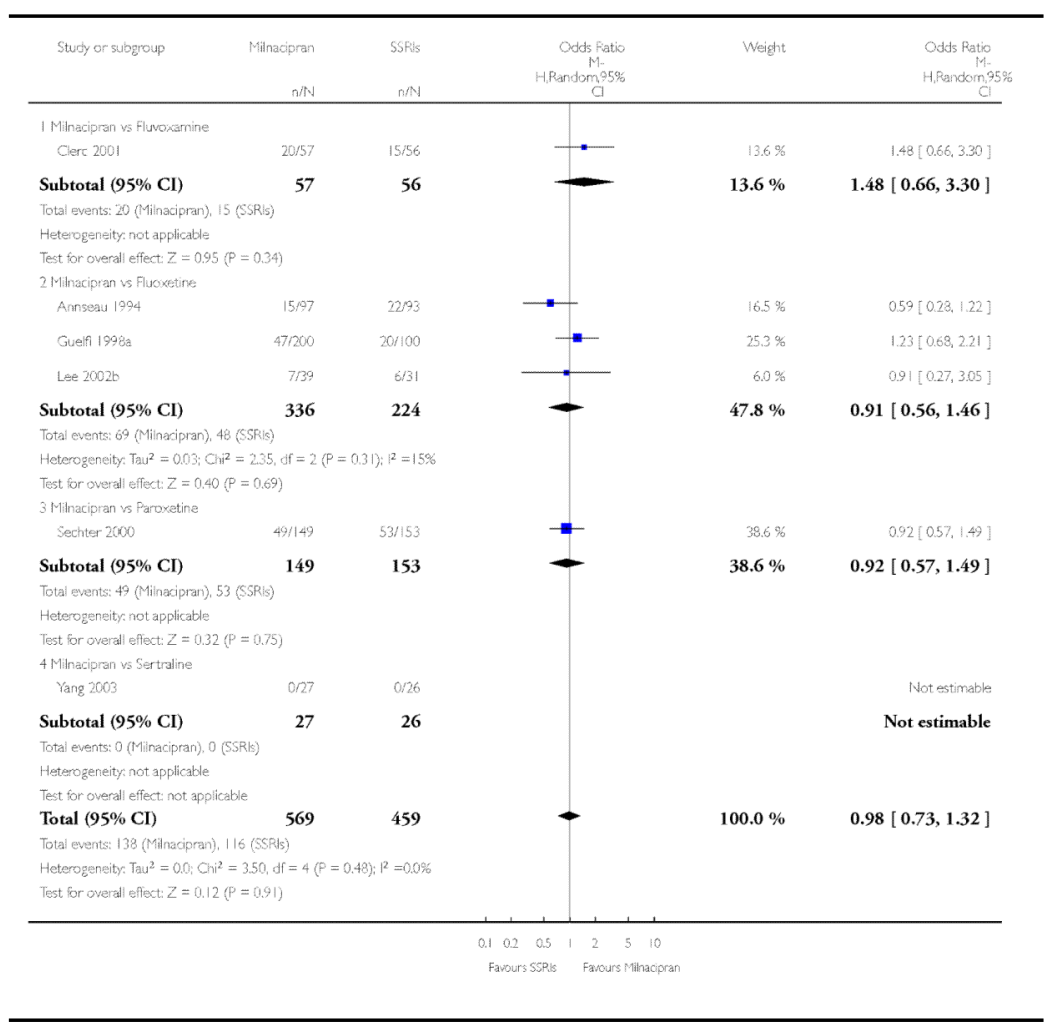




\section{Analysis 5.1}

Comparison 5 Remission at early phase (1-4 weeks),

\section{Outcome 1 Milnacipran vs TCAs}

Review: Milnacipran versus other antidepressive agents for depression Comparison: 5 Remission at early phase (1-4 weeks)

Outcome: 1 Milnacipran vs TCAs

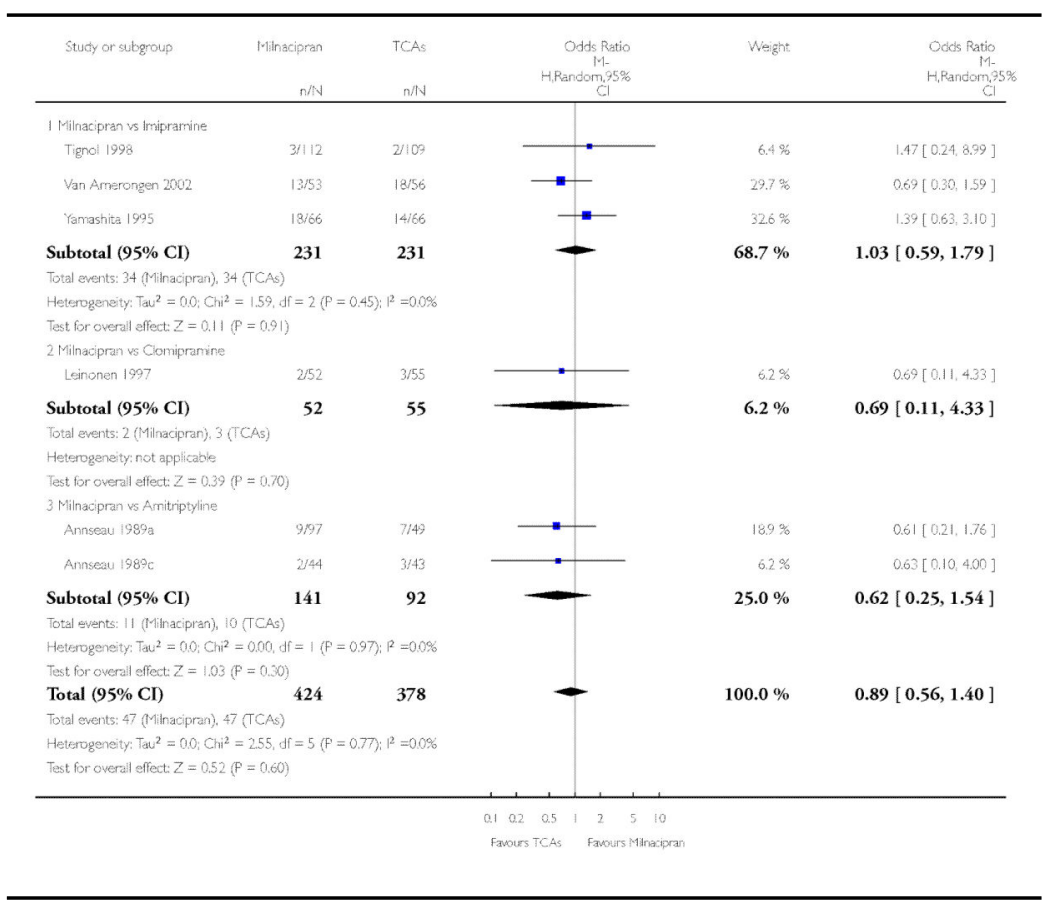


Analysis 5.2

Comparison 5 Remission at early phase (1-4 weeks), Outcome 2 Milnacipran vs SSRIs

Review: Milnacipran versus other antidepressive agents for depression Comparison: 5 Remission at early phase (1-4 weeks)

Outcome: 2 Milnacipran vs SSRIs

\begin{tabular}{|c|c|c|c|c|c|}
\hline Study or subgroup & Mithacipran & $\begin{array}{l}\text { SSRls } \\
\text { ndN } \\
\end{array}$ & $\begin{array}{r}\text { Odds Ratio } \\
\text { Ma- } \\
\text { HAandorn } 95 \% \\
\mathrm{CI}\end{array}$ & Weight & 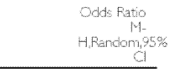 \\
\hline \multicolumn{6}{|c|}{1 Minaspran ys Fluyoramine } \\
\hline Annseav $199 \mathrm{ic}$ & $9 / 96$ & 34 & $\cdot$ & $14.1 \%$ & $1.48[0.38,5.79]$ \\
\hline derc 2001 & $5 / 57$ & $4 / 56$ & 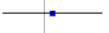 & $13.9 \%$ & $1.25[0.32,4.92]$ \\
\hline Subtotal $(95 \% \mathrm{CI})$ & 143 & 97 & & $28.0 \%$ & $1.36[0.52,3.58]$ \\
\hline \multicolumn{6}{|c|}{ Total everts: 14 (Milinacipran), $7(\mathrm{~S}(\mathrm{~S} / \mathrm{s})$} \\
\hline \multicolumn{6}{|c|}{ Heterogenety: Tau ${ }^{2}=0.0 ; 0 i^{2}=0.03$, df $=1 \quad(P=0.86) ; 1^{2}=0.0 \% 6$} \\
\hline \multicolumn{6}{|c|}{ Test for overalil effect: $Z=0.63\langle P=0.53\rangle$} \\
\hline \multicolumn{6}{|c|}{ 2Minacipran ws Fluoretine } \\
\hline Guefil 19983 & 201200 & $6 / 100$ & 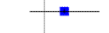 & $29.2 \%$ & $1.74[0.68,4.48]$ \\
\hline Lee $2002 b$ & $2 / 39$ & $|/ 3|$ & & $4.4 \%$ & $1.62[0.14,1876]$ \\
\hline Subtotal $(95 \% \mathrm{CI})$ & 239 & 131 & - & $33.6 \%$ & $1.72[0.71,4.17]$ \\
\hline \multicolumn{6}{|c|}{ Total events: 22 (Milinatipran), 7 (SSRs) } \\
\hline \multicolumn{6}{|c|}{ Heterogenety. $\operatorname{Tau}^{2}=0,0 \mathrm{it}^{2}=0,00, \mathrm{df}=1(\mathrm{p}=0.96): 1^{2}=0.0 \%$} \\
\hline \multicolumn{6}{|c|}{ Test for overall effect: $Z=1.21(P=0.23)$} \\
\hline \multicolumn{6}{|c|}{3 Miliacipran ws Parroxscting } \\
\hline Sechter 2000 & $9 / 49$ & $9 / 153$ & 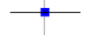 & $28.8 \%$ & $1.03[0.40,2.67]$ \\
\hline Shinkai 2004 & $3 / 20$ & $4 / 2 !$ & - & $9.7 \%$ & $0.75[0.15,3.87]$ \\
\hline Subtotal $(95 \% \mathrm{CI})$ & 169 & 174 & 一 & $38.5 \%$ & $0.95[0.42,2.17]$ \\
\hline \multicolumn{6}{|c|}{ Total events: 12 (Militiactipran), 13 (SSFik) } \\
\hline \multicolumn{6}{|c|}{ 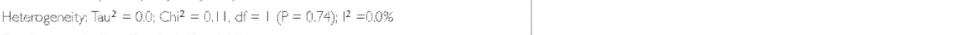 } \\
\hline \multicolumn{6}{|c|}{ Test for overall effect: $Z=0.12(p=0.90)$} \\
\hline Total $(95 \% \mathrm{CI})$ & 551 & 402 & - & $100.0 \%$ & $1.28[0.77,2.14]$ \\
\hline \multicolumn{6}{|c|}{ Total event: 48 (Milinacipran), 27 (SSPlis) } \\
\hline \multicolumn{6}{|c|}{ Heterogenety. Tau $^{2}=0, \mathrm{Ci}^{2}=1.10$, df $=5\langle P=0.95\rangle ; 1^{2}=0.00 \%$} \\
\hline \multicolumn{6}{|c|}{ Test for overall effect: $Z=0.96\langle P=0.34\rangle$} \\
\hline & & & $\begin{array}{cccc}0.5 & 1 & 2 & 5 \\
\text { SSFls } & \text { Faveurs M }\end{array}$ & & \\
\hline
\end{tabular}

Analysis 5.3

Comparison 5 Remission at early phase (1-4 weeks), Outcome 3 Milnacipran vs Heterocyclics

Review: Milnacipran versus other antidepressive agents for depression Comparison: 5 Remission at early phase (1-4 weeks)

Outcome: 3 Milnacipran vs Heterocyclics

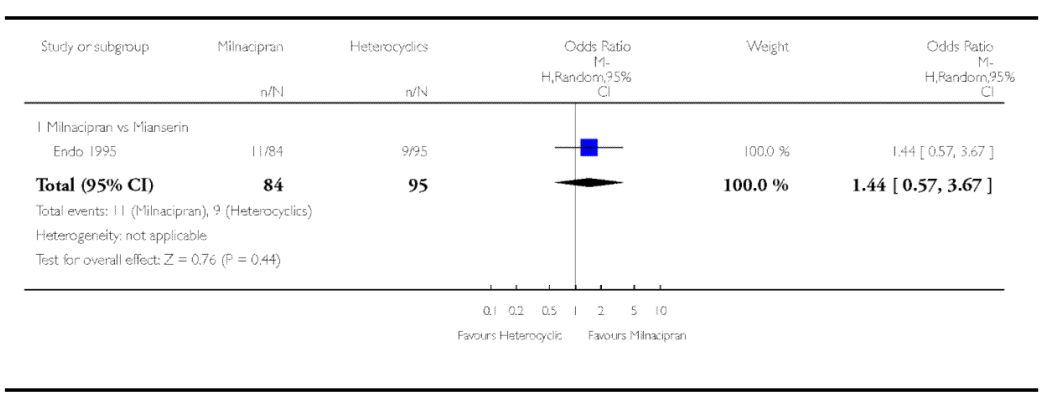




\section{Analysis 6.1}

Comparison 6 Remission at follow-up phase (4-6 months), Outcome 1 Milnacipran vs TCAs

Review: Milnacipran versus other antidepressive agents for depression Comparison: 6 Remission at follow-up phase (4-6 months)

Outcome: 1 Milnacipran vs TCAs

\begin{tabular}{|c|c|c|c|c|c|}
\hline Study or subgroup & $\begin{array}{r}\text { Milinsipran } \\
n / N \\
\end{array}$ & TEAs & $\begin{array}{l}\text { Odds Patio } \\
\text { M- } \\
\text { HRandom } 25 \% \\
\text { CI }\end{array}$ & Weight & $\begin{array}{l}\text { Odda Patio } \\
\text { H. Random.95\% } \\
\quad \mathrm{C}\end{array}$ \\
\hline \multicolumn{6}{|c|}{ I Milhacipran vs Comiprarraing } \\
\hline \multicolumn{6}{|c|}{ 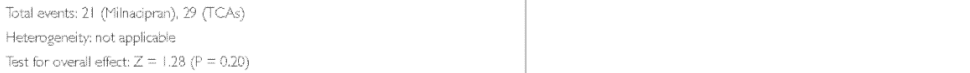 } \\
\hline & & & 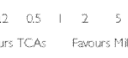 & & \\
\hline
\end{tabular}

\section{Analysis 7.1}

Comparison 7 Depression scale-end point score at acute phase (6-12 weeks), Outcome 1 Milnacipran vs TCAs

Review: Milnacipran versus other antidepressive agents for depression Comparison: 7 Depression scale-end point score at acute phase (6-12 weeks) Outcome: 1 Milnacipran vs TCAs

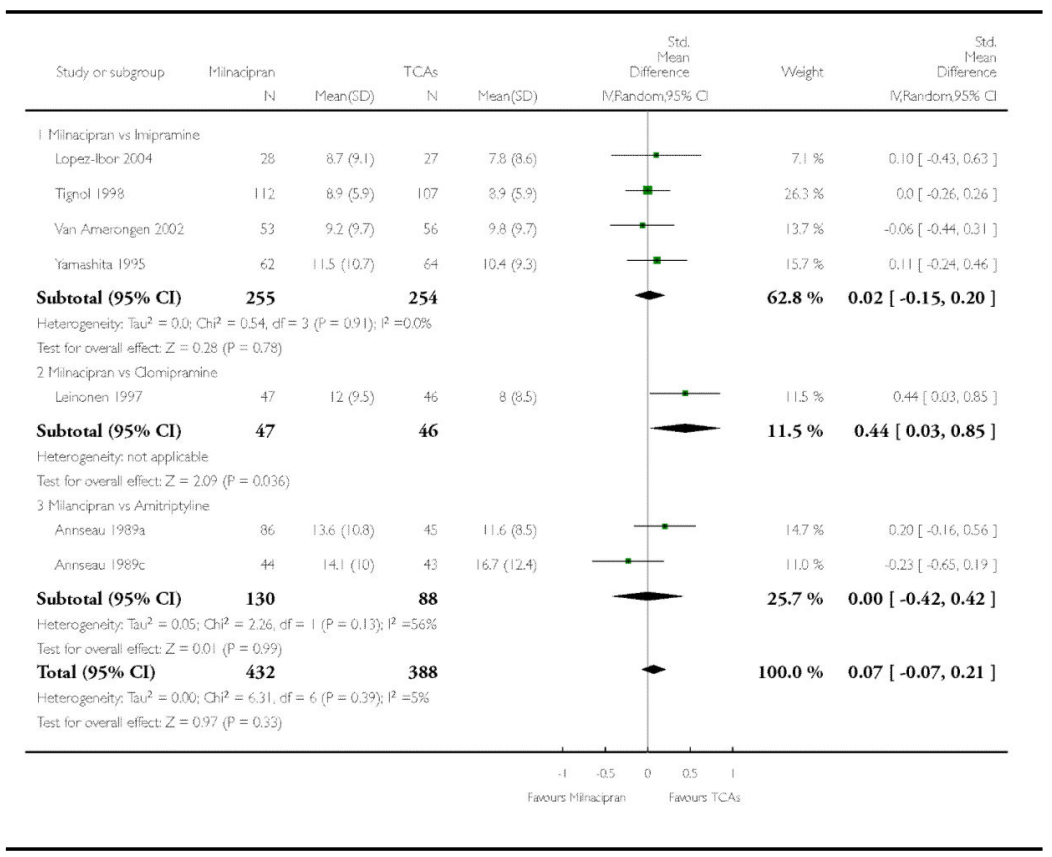


Analysis 7.2

Comparison 7 Depression scale-end point score at acute phase (6-12 weeks), Outcome 2 Milnacipran vs SSRIs

Review: Milnacipran versus other antidepressive agents for depression Comparison: 7 Depression scale-end point score at acute phase (6-12 weeks) Outcome: 2 Milnacipran vs SSRIs

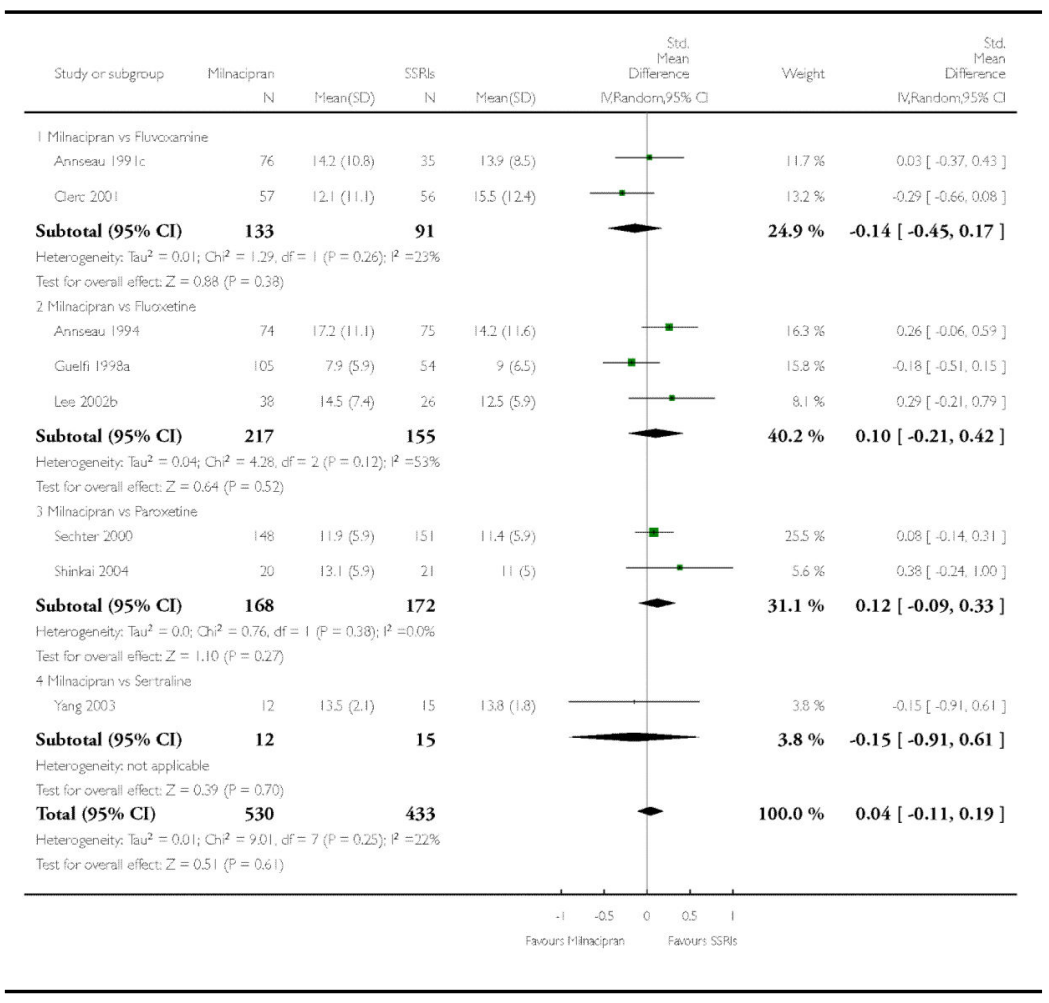




\section{Analysis 7.3}

Comparison 7 Depression scale-end point score at acute phase (6-12 weeks), Outcome 3 Milnacipran vs

Heterocyclics

Review: Milnacipran versus other antidepressive agents for depression Comparison: 7 Depression scale-end point score at acute phase (6-12 weeks) Outcome: 3 Milnacipran vs Heterocyclics

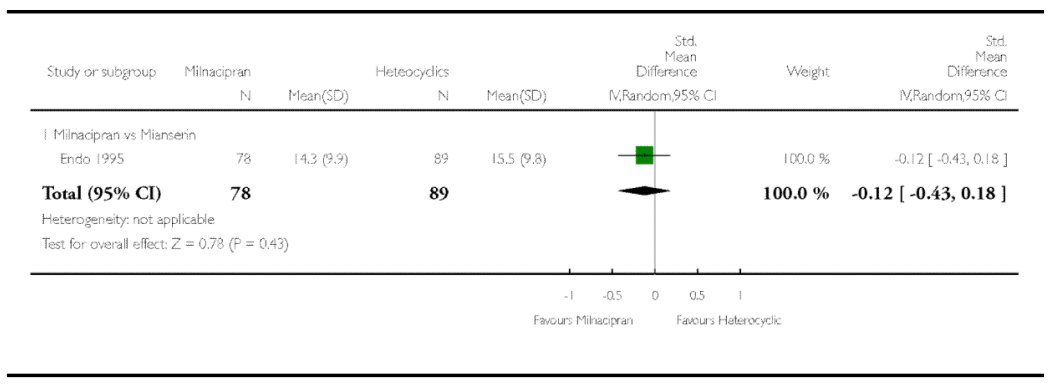

Analysis 8.1

Comparison 8 Depression scale-end point score at early phase (1-4 weeks), Outcome 1 Milnacipran vs TCAs

Review: Milnacipran versus other antidepressive agents for depression

Comparison: 8 Depression scale-end point score at early phase (1-4 weeks) Outcome: 1 Milnacipran vs TCAs

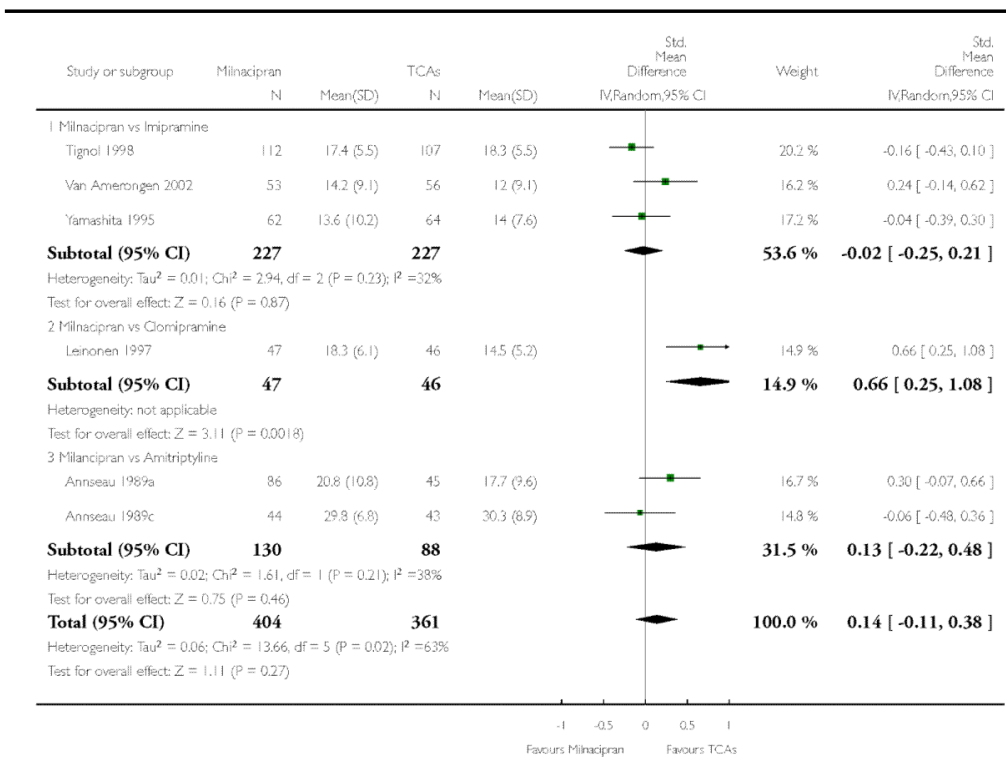


Analysis 8.2

Comparison 8 Depression scale-end point score at early phase (1-4 weeks), Outcome 2 Milnacipran vs SSRIs

Review: Milnacipran versus other antidepressive agents for depression Comparison: 8 Depression scale-end point score at early phase (1-4 weeks) Outcome: 2 Milnacipran vs SSRIs

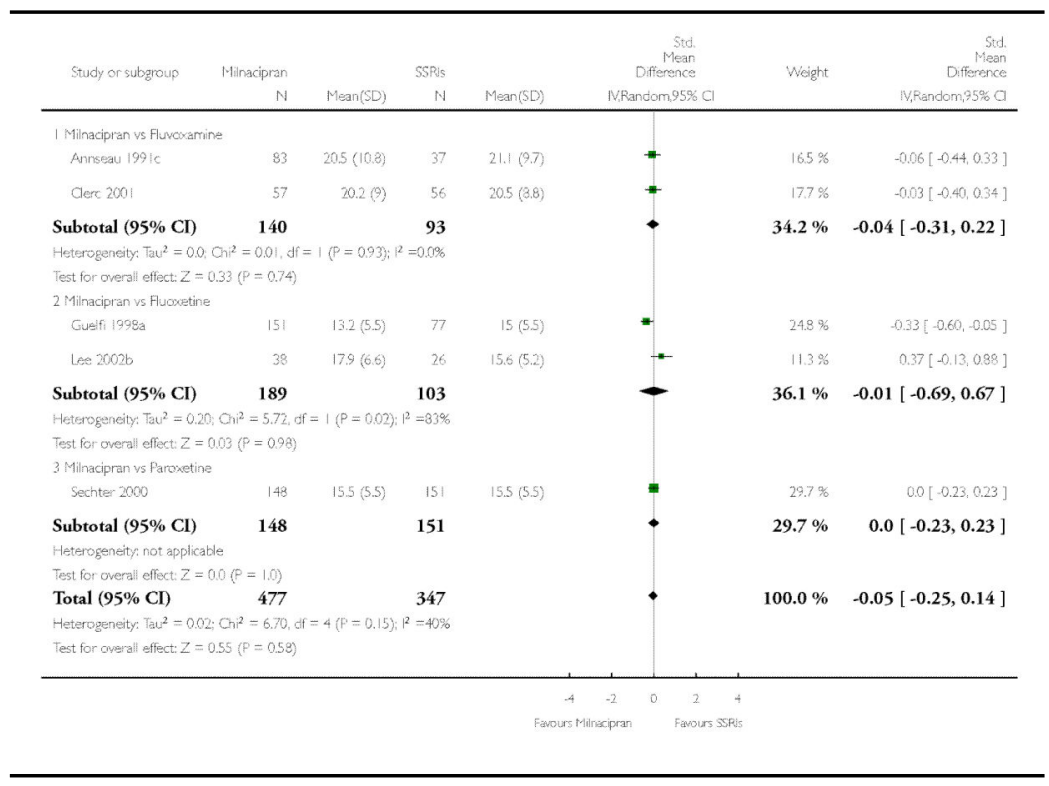

Analysis 8.3

Comparison 8 Depression scale-end point score at early phase (1-4 weeks), Outcome 3 Milnacipran vs

Heterocyclics

Review: Milnacipran versus other antidepressive agents for depression Comparison: 8 Depression scale-end point score at early phase (1-4 weeks) Outcome: 3 Milnacipran vs Heterocyclics

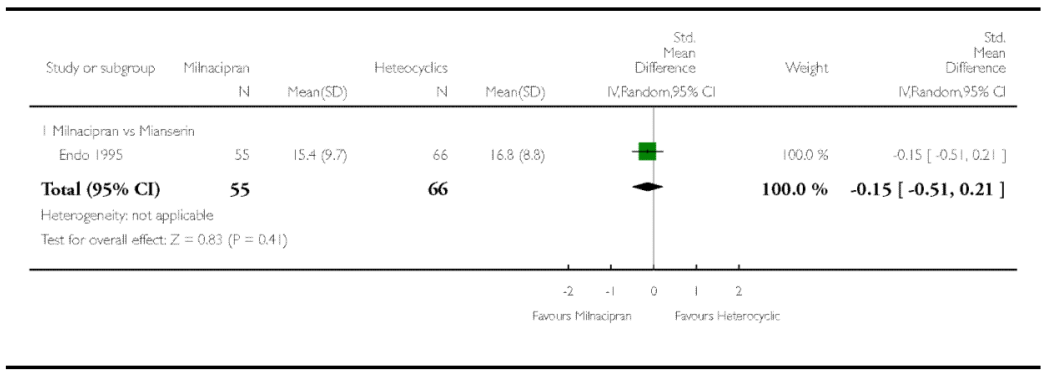


Analysis 9.1

Comparison 9 Total dropouts (any reason), Outcome 1

Milnacipran vs TCAs

Review: Milnacipran versus other antidepressive agents for depression Comparison: 9 Total dropouts (any reason)

Outcome: 1 Milnacipran vs TCAs

\begin{tabular}{|c|c|c|c|c|c|}
\hline Study or subgroup & $\begin{array}{r}\text { Malnegipian } \\
n / N \\
\end{array}$ & $\begin{array}{l}\text { TCAs } \\
\text { nN: } \\
\end{array}$ & $\begin{array}{l}\text { Odds Rato } \\
\text { M, Fiandom } 95 \%\end{array}$ & Weght & $\begin{array}{l}\text { Odds Pato } \\
\text { He Pandom } 95 \\
\end{array}$ \\
\hline \multicolumn{6}{|l|}{ II Minacipran vs Imipramine } \\
\hline Lopez:-1bor 2004 & $23 / 51$ & 2249 & $\because$ & $17.1 \%$ & $1.01[0.46,2.22]$ \\
\hline Tigrol 1998 & $3 \% 112$ & 35109 & & $26.7 \%$ & $1.13[0.65,198]$ \\
\hline Van Amerorgen 2002 & $1 / 53$ & 24,56 & & $15.3 \%$ & $0.35[0.15,0.82]$ \\
\hline Yenrashita 1995 & 22260 & $19: 66$ & & $187 \%$ & $1.24[0.59,2.59]$ \\
\hline Subtotal $(95 \% \mathrm{CI})$ & 282 & 280 & & $77.8 \%$ & $0.88[0.52,1.48]$ \\
\hline \multicolumn{6}{|c|}{ Total events: 95 (Milinadipran), 100 (TCAs) } \\
\hline \multicolumn{6}{|c|}{ Heterogenety: $\mathrm{Tau}^{2}=0.14 ; \mathrm{CH}^{2}=6.19, \mathrm{df}=3(\mathrm{~F}=0.10) ; \mathrm{I}^{2}=52 \%$} \\
\hline \multicolumn{6}{|c|}{ Fest for coverall effect: $Z=0.49(P=0.62)$} \\
\hline \multicolumn{6}{|c|}{2 Minasipratin vs Amitriptydine } \\
\hline Annscau 1989a & 24,97 & $11 / 49$ & $=$ & $163 \%$ & $1.14[0.50,256]$ \\
\hline Annseau $1939 \mathrm{c}$ & 344 & $5 / 43$ & & $59 \%$ & $0.56[0.12 .249]$ \\
\hline Subtotal $(95 \% \mathrm{CI})$ & 141 & 92 & & $22.2 \%$ & $0.97[0.47,1.97]$ \\
\hline \multicolumn{6}{|c|}{ Total events: 27 (Milmaxipran), 16 (TCAs) } \\
\hline \multicolumn{6}{|c|}{ Heterogenety: $T_{a u^{2}}=0.0 ; C h i^{2}=0.67, d f=1(P=0.41) ; i^{2}=0.0 \%$} \\
\hline \multicolumn{6}{|c|}{ Test for overall oflect: $Z=0.10(P=0.92)$} \\
\hline Total $(95 \% \mathrm{CI})$ & 423 & 372 & & $100.0 \%$ & $0.90[0.62,1.33]$ \\
\hline \multicolumn{6}{|c|}{ Total events: 122 (Minacipran), $116(T C A s)$} \\
\hline \multicolumn{6}{|c|}{ Hetergenety: $\mathrm{Tau}^{2}=0.06 ; \mathrm{CH}^{2}=6.8 \mathrm{~B}, \mathrm{df}=5(\mathrm{~F}=0.23) ; \mathrm{P}^{2}=27 \%$} \\
\hline \multicolumn{6}{|c|}{ Test for overal effect: $Z=0.52(P=0.60)$} \\
\hline & & & 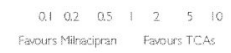 & & \\
\hline
\end{tabular}


Analysis 9.2

Comparison 9 Total dropouts (any reason), Outcome 2

Milnacipran vs SSRIs

Review: Milnacipran versus other antidepressive agents for depression Comparison: 9 Total dropouts (any reason)

Outcome: 2 Milnacipran vs SSRIs

\begin{tabular}{|c|c|c|c|c|c|}
\hline Study or subgroup & Minraciprant & 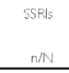 & $\begin{array}{c}\text { Oddos Patio } \\
\text { M. Prandom } 95 \% \\
\text { He }\end{array}$ & Weight & $\begin{array}{l}\text { Odds Ratio } \\
\text { M. } \\
\text { H.Random } 959 \\
\end{array}$ \\
\hline \multicolumn{6}{|l|}{ I Milancipran vs fluvoxamine } \\
\hline Annseau $1991 \mathrm{c}$ & $10: 86$ & $6 / 41$ & $\longrightarrow$ & $60 \%$ & $0.77[0.26,2.28]$ \\
\hline Gerc 2001 & $15: 57$ & $17 / 56$ & $\longrightarrow$ & $10.6 \%$ & $0.82[0.36,186]$ \\
\hline Subtotal $(95 \% \mathrm{CI})$ & 143 & 97 & - & $16.7 \%$ & $0.80[0.42,1.54]$ \\
\hline \multicolumn{6}{|c|}{ Total events: 25 (Milraciprar), 23 (SSRlis) } \\
\hline \multicolumn{6}{|c|}{ 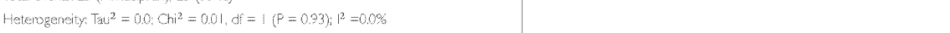 } \\
\hline \multicolumn{6}{|c|}{ Test for overall effect: $Z=0.67(P=0.50)$} \\
\hline \multicolumn{6}{|c|}{ 2.Milascipran us fluoxetices } \\
\hline Annscau 1994 & 23197 & $13: 93$ & $\cdot$ & $14.8 \%$ & $1.30[0.65,260]$ \\
\hline Guelâ $1998 \mathrm{Ba}$ & $99 / 200$ & $50 / 100$ & - & $310 \%$ & $0.88[0.61,1.58]$ \\
\hline Lee $2002 b$ & 1639 & $15 / 31$ & $\rightarrow$ & $7.9 \%$ & $0.74[0.29,1.92]$ \\
\hline Subtotal $(95 \% \mathrm{CI})$ & 336 & 224 & - & $53.7 \%$ & $1.02[0.71,1.46]$ \\
\hline \multicolumn{6}{|c|}{ 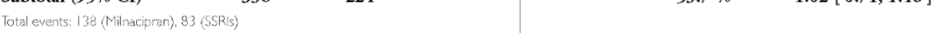 } \\
\hline \multicolumn{6}{|c|}{ Heterogensity: $\mathrm{Zau}^{2}=0.0 ; \mathrm{Ch}^{2}=091$, di $=2(\mathrm{P}=0.63) ; \mathrm{i}^{2}=0.0 \%$} \\
\hline \multicolumn{6}{|c|}{ Test for overal effect $Z=0.050(P=0.93)$} \\
\hline \multicolumn{6}{|c|}{3 Militacipran ys Paroxeting } \\
\hline Sechter 2000 & 29149 & $33 / 153$ & & $229 \%$ & $0.88[0.50,1.54]$ \\
\hline Shinka 2004 & 0,20 & 121 & & $0.7 \%$ & $0.33[0.01,8.67]$ \\
\hline Subtotal $(95 \% \mathrm{CI})$ & 169 & 174 & $=$ & $23.5 \%$ & $0.85[0.49,1.48]$ \\
\hline \multicolumn{6}{|c|}{ Total events: 29 (Milinacpran), 34 (SSRlis) } \\
\hline \multicolumn{6}{|c|}{ Heterogenaty: $\operatorname{Tav}^{2}=0,0 ; \mathrm{Chi}^{2}=0.33, \mathrm{~d}=1,(p=0.57) ;\left.\right|^{2}=0.0 \%$} \\
\hline \multicolumn{6}{|c|}{ Test for overall effect $Z=0.56(P=0.58)$} \\
\hline \multicolumn{6}{|c|}{4 Milancipran vis Sertraine } \\
\hline Tang 2003 & $15 / 27$ & 1126 &. & $6.1 \%$ & $1.70[0.57,5.05]$ \\
\hline Subtotal $(95 \% \mathrm{CI})$ & 27 & 26 & - & $6.1 \%$ & $1.70[0.57,5.05]$ \\
\hline \multicolumn{6}{|c|}{ Total events: 15 (Milhaciprar). 11 (SSFiss) } \\
\hline \multicolumn{6}{|c|}{ Hetrogenasty: not applicatle } \\
\hline \multicolumn{6}{|c|}{ Test for overall effect: $Z=0.96(P=0.34)$} \\
\hline Total $(95 \% \mathrm{Cl})$ & 675 & 521 & - & $100.0 \%$ & $0.97[0.74,1.26]$ \\
\hline \multicolumn{6}{|c|}{ Total events: 207 (Milinaciparan), 151 (SSRRs) } \\
\hline \multicolumn{6}{|c|}{ Heterogenaty: $\mathrm{TaU}^{2}=60 ; \mathrm{Chi}^{2}=283, \mathrm{df}=7(f=0,00) ; 1^{2}=0,0 \%$} \\
\hline \multicolumn{6}{|c|}{ Test for overal effect: $Z=0.24(P=0.81)$} \\
\hline & & & 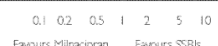 & & \\
\hline
\end{tabular}




\section{Analysis 9.3}

Comparison 9 Total dropouts (any reason), Outcome 3 Milnacipran vs Heterocyclics

Review: Milnacipran versus other antidepressive agents for depression Comparison: 9 Total dropouts (any reason)

Outcome: 3 Milnacipran vs Heterocyclics

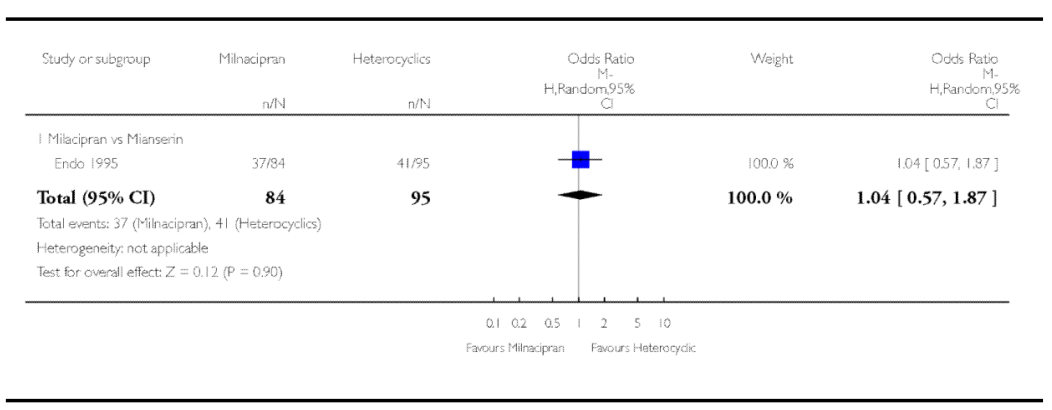

\section{Analysis 10.1}

Comparison 10 Dropouts due to inefficacy, Outcome 1 Milnacipran vs TCAs

Review: Milnacipran versus other antidepressive agents for depression Comparison: 10 Dropouts due to inefficacy

Outcome: 1 Milnacipran vs TCAs

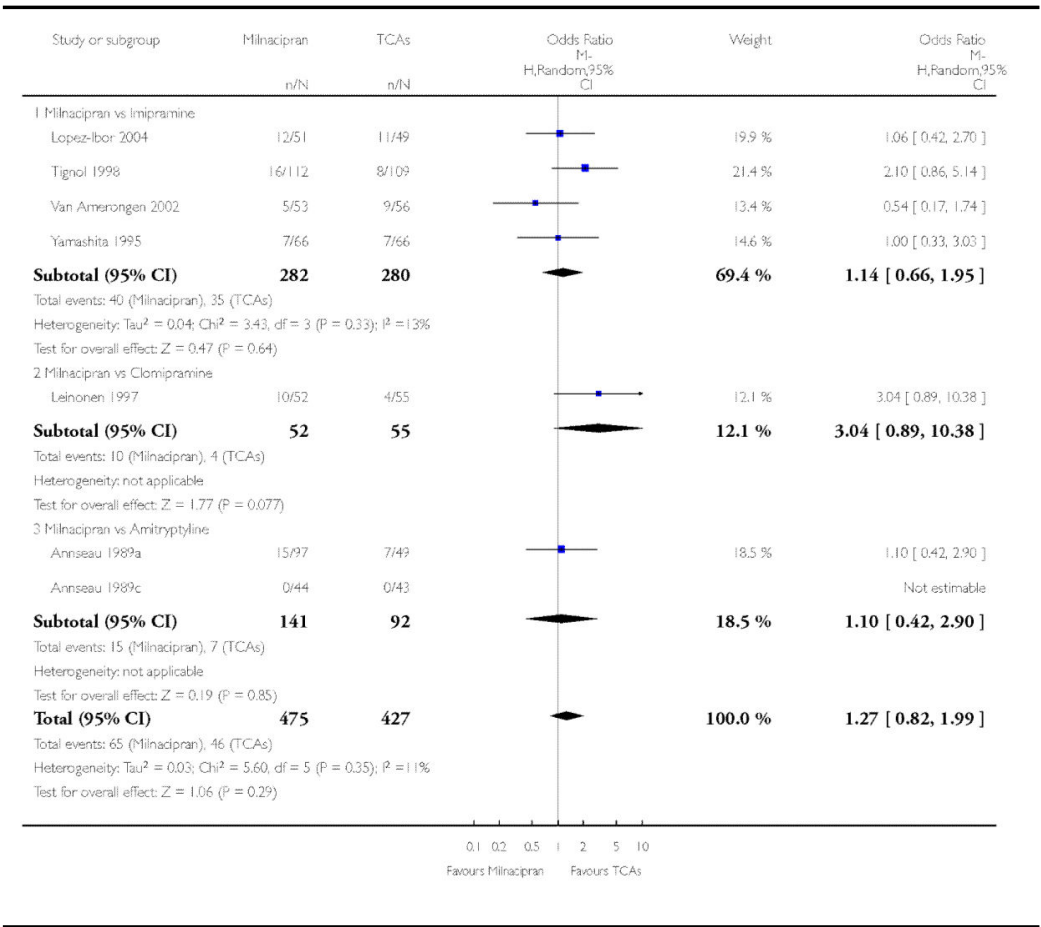




\section{Analysis 10.2}

Comparison 10 Dropouts due to inefficacy, Outcome 2 Milnacipran vs SSRIs

Review: Milnacipran versus other antidepressive agents for depression Comparison: 10 Dropouts due to inefficacy

Outcome: 2 Milnacipran vs SSRIs

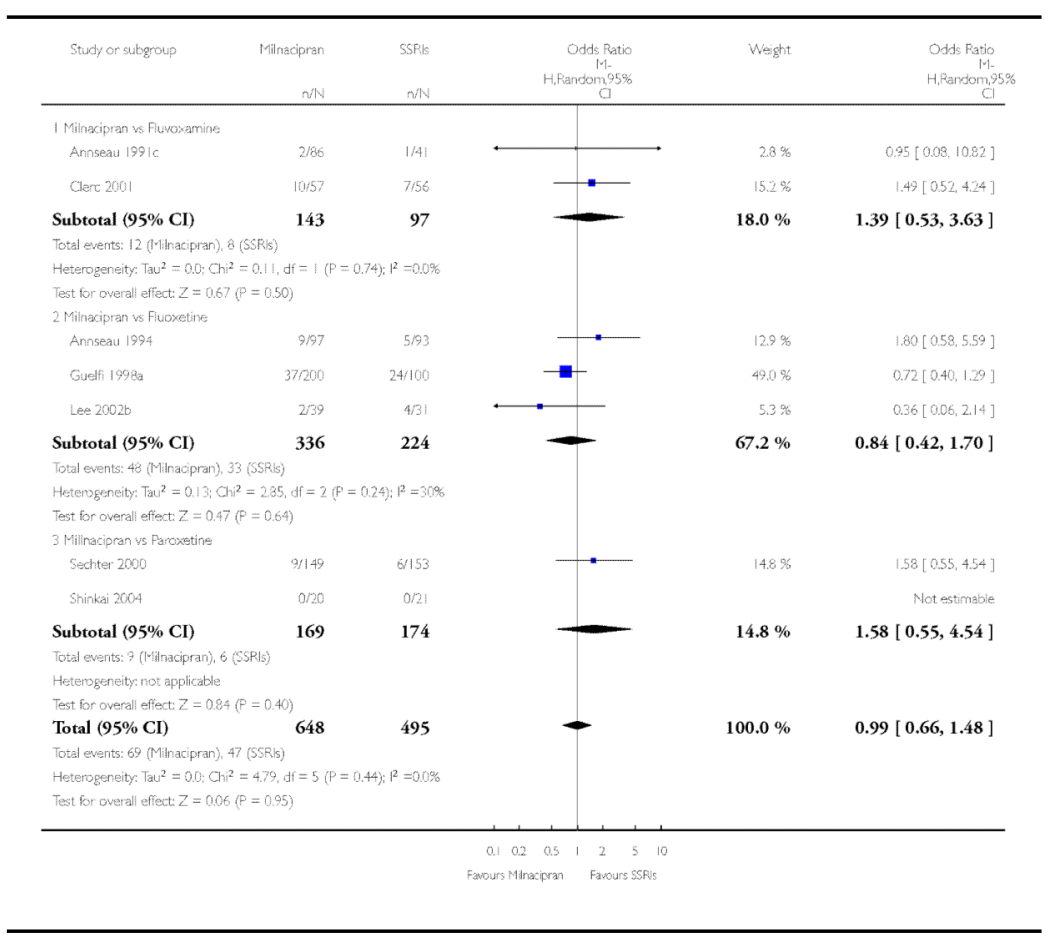

Analysis 10.3

Comparison 10 Dropouts due to inefficacy, Outcome 3 Milnacipran vs Heterocyclics

Review: Milnacipran versus other antidepressive agents for depression Comparison: 10 Dropouts due to inefficacy

Outcome: 3 Milnacipran vs Heterocyclics

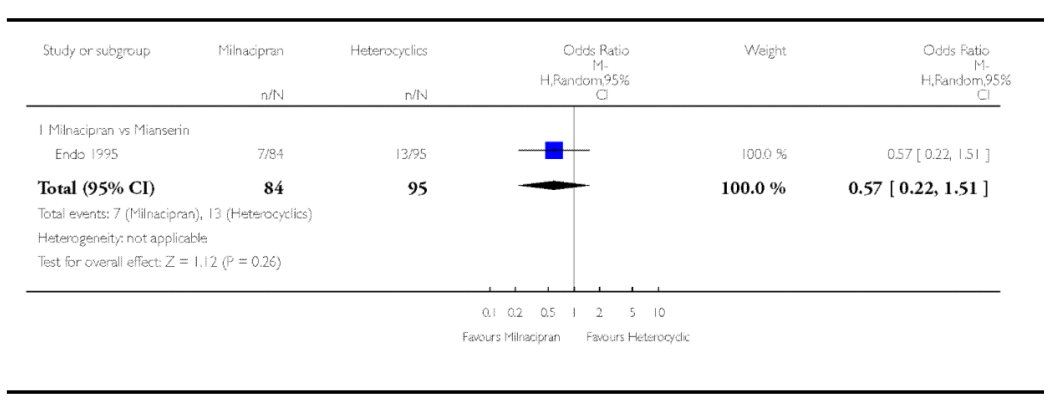




\section{Analysis 11.1}

Comparison 11 Dropouts due to adverse events, Outcome 1 Milnacipran vs TCAs

Review: Milnacipran versus other antidepressive agents for depression Comparison: 11 Dropouts due to adverse events Outcome: 1 Milnacipran vs TCAs

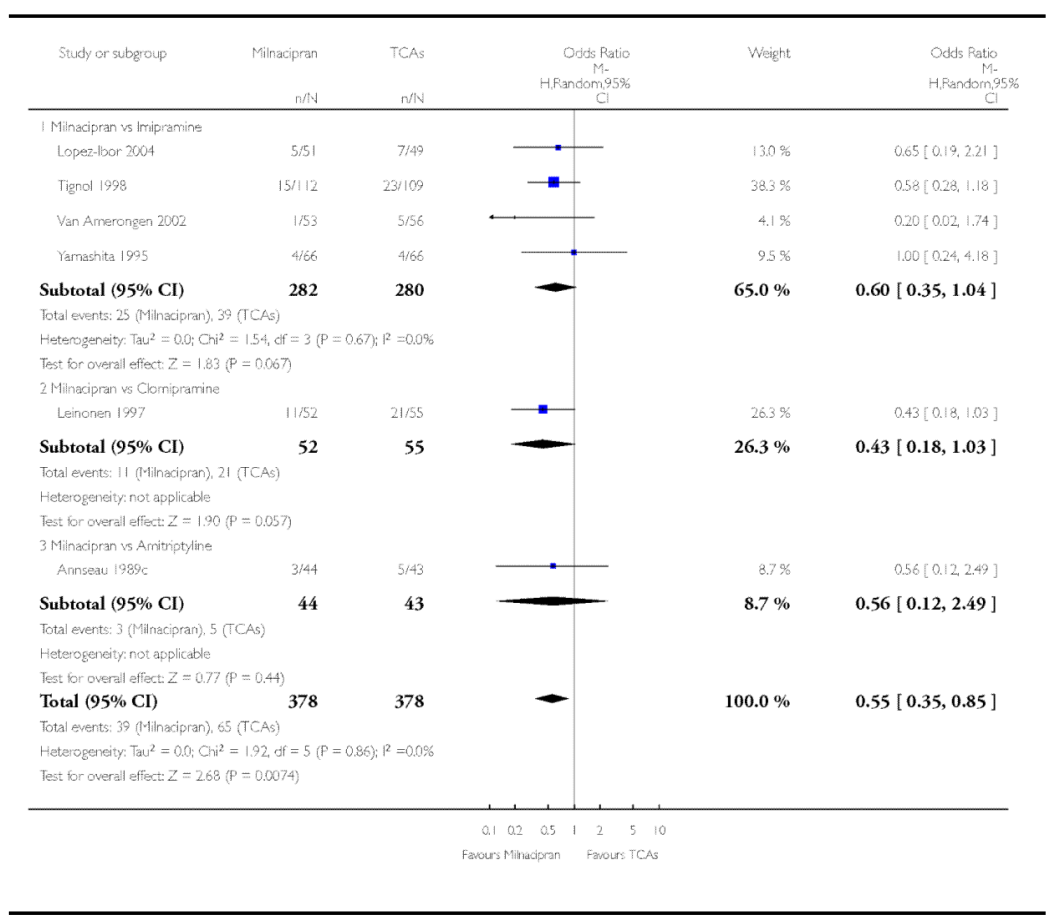




\section{Analysis 11.2}

Comparison 11 Dropouts due to adverse events, Outcome 2 Milnacipran vs SSRIs

Review: Milnacipran versus other antidepressive agents for depression Comparison: 11 Dropouts due to adverse events

Outcome: 2 Milnacipran vs SSRIs

\begin{tabular}{|c|c|c|c|c|c|}
\hline Study or subgoip & Milinaciptan & $\begin{array}{l}\text { SSRis } \\
\mathrm{n} / \mathrm{N} \\
\end{array}$ & $\begin{array}{r}\text { Odds Ratio } \\
\text { MFixndom } 95 \% \\
\end{array}$ & Weight & $\begin{array}{l}\text { Ddids Patio } \\
\text { H.Paridom } 95 \% \\
\end{array}$ \\
\hline \multicolumn{6}{|l|}{1 Minacipran vs Fluoxamine } \\
\hline Annseau $199 \mathrm{lc}$ & 7886 & $5 / 4 !$ & $\rightarrow$ & $10.3 \%$ & $0.64[0.19,2.15]$ \\
\hline are 2001 & 1,57 & $4 / 56$ & & $3.1 \%$ & $0.23[0.03 .2 .15]$ \\
\hline Subtotal $(95 \% \mathrm{CI})$ & 143 & 97 & & $13.4 \%$ & $0.51[0.17,1.47]$ \\
\hline \multicolumn{6}{|c|}{ Total events: 8 (Milinacipran), 9 (SSRIS) } \\
\hline \multicolumn{6}{|c|}{ Heterogeneity: Tav $^{2}=0, \mathrm{Ch}^{2}=0.62, \mathrm{df}=1 \quad(\mathrm{P}=0.43\rangle ; \mathrm{l}^{2}=0.0 \%$} \\
\hline \multicolumn{6}{|c|}{ Test for overal efiect: $Z=1.25(p=0.21)$} \\
\hline \multicolumn{6}{|c|}{2 Milnacipran vs Fuoxetine } \\
\hline Annesau 199.4 & 6997 & $7 / 93$ & $*$ & $11.9 \%$ & $0.81[0.26,251]$ \\
\hline Guelf 1998 & 23200 & 19100 & $\rightarrow$ & $37.1 \%$ & $0.69[0.37,1.32]$ \\
\hline Loe 20026 & $2 / 39$ & $3 / 31$ & & $4.4 \%$ & $0.50[0.08,323]$ \\
\hline Subtotal $(95 \% \mathrm{CI})$ & 336 & 224 & - & $53.4 \%$ & $0.70[0.41,1.19]$ \\
\hline \multicolumn{6}{|c|}{ Total events: 36 (Milinaciprar), 29 (SSPRs) } \\
\hline \multicolumn{6}{|c|}{ 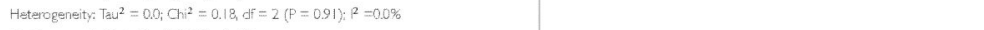 } \\
\hline \multicolumn{6}{|c|}{ Test for overall effect $Z=1.31(p=0.19)$} \\
\hline \multicolumn{6}{|c|}{3 Milancipran va Parorketine } \\
\hline Sechter 2000 & $17 / 149$ & $20 / 153$ & & $31,9 \%$ & $0.86\left[0.43_{2} .1 .71\right]$ \\
\hline Stinkai 2004 & 020 & $1 / 21$ & & $1.4 \%$ & $0.33[0.01,8.67]$ \\
\hline Subtotal $(95 \% \mathrm{CI})$ & 169 & 174 & - & $33.3 \%$ & $0.82[0.42,1.62]$ \\
\hline \multirow{2}{*}{\multicolumn{6}{|c|}{ 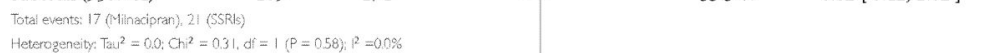 }} \\
\hline & & & & & \\
\hline \multicolumn{6}{|c|}{ Test tor averall effect $Z=0.57(p=0,57)$} \\
\hline Total $(95 \% \mathrm{CI})$ & 648 & 495 & - & $100.0 \%$ & $0.71[0.48,1.04]$ \\
\hline \multicolumn{6}{|c|}{ 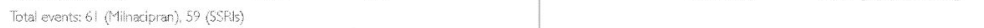 } \\
\hline \multicolumn{6}{|c|}{ 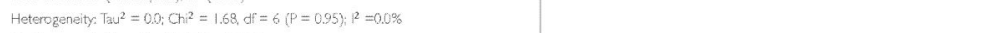 } \\
\hline \multicolumn{6}{|c|}{ Test for overal effect: $Z=1.74(p=0021)$} \\
\hline & & & 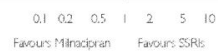 & & \\
\hline
\end{tabular}

Analysis 11.3

Comparison 11 Dropouts due to adverse events, Outcome 3 Milnacipran vs Heterocyclics

Review: Milnacipran versus other antidepressive agents for depression Comparison: 11 Dropouts due to adverse events

Outcome: 3 Milnacipran vs Heterocyclics

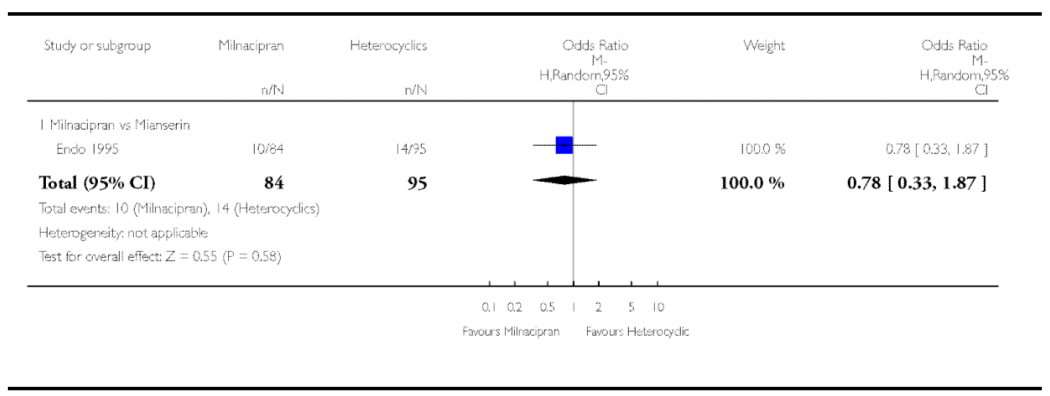


Analysis 12.1

Comparison 12 Patients with at least some adverse events (Tolerability), Outcome 1 Milnacipran vs TCAs

Review: Milnacipran versus other antidepressive agents for depression Comparison: 12 Patients with at least some adverse events (Tolerability) Outcome: 1 Milnacipran vs TCAs

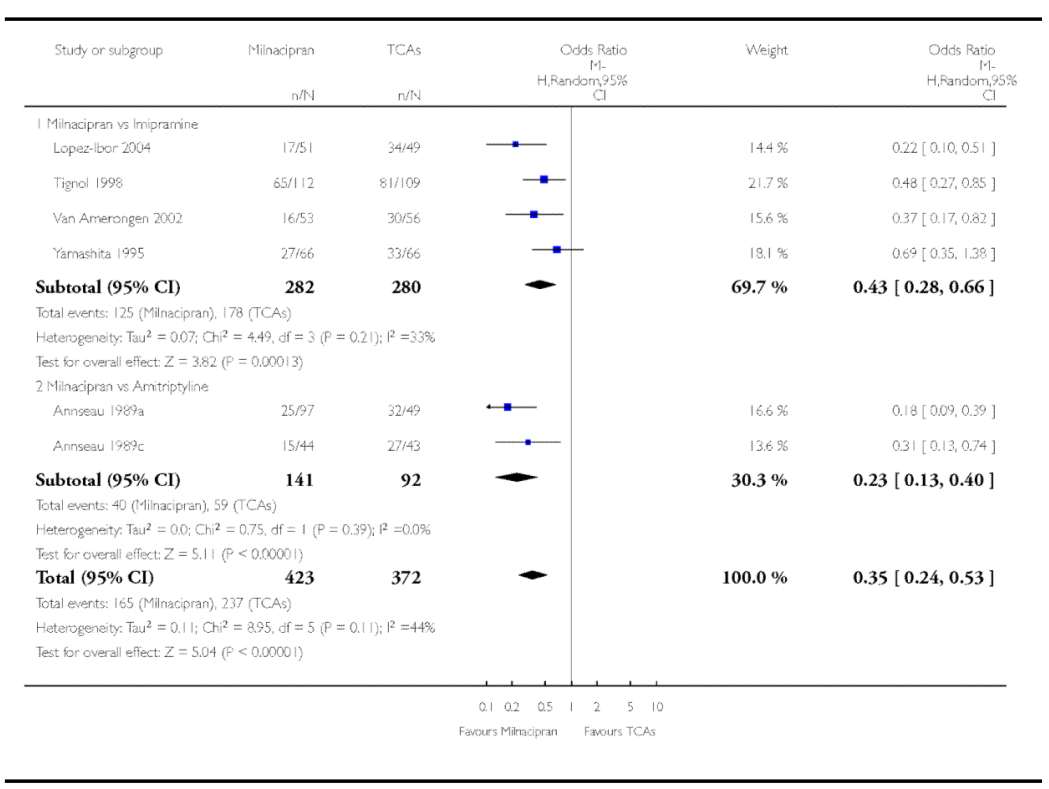




\section{Analysis 12.2}

\section{Comparison 12 Patients with at least some adverse events (Tolerability), Outcome 2 Milnacipran vs SSRIs}

Review: Milnacipran versus other antidepressive agents for depression Comparison: 12 Patients with at least some adverse events (Tolerability) Outcome: 2 Milnacipran vs SSRIs

\begin{tabular}{|c|c|c|c|c|c|}
\hline Study or subgroup & Milinacipran & $\begin{array}{l}\text { SSRIS } \\
\text { nWN } \\
\end{array}$ & $\begin{array}{c}\text { Ofds Fiatio } \\
\text { M. } \\
\text { HPandom } 95 \% \\
\end{array}$ & Weght & $\begin{array}{l}\text { Odes Ratio } \\
\text { HRandom, } 95 \%\end{array}$ \\
\hline \multicolumn{6}{|l|}{ I Mnacipran vs Fluwoxamine } \\
\hline Annseau $199 \mathrm{ic}$ & 32136 & 22041 & & $20.9 \%$ & $0.51[0.24 .109]$ \\
\hline Ciere 2001 & $7 / 57$ & $12 / 56$ & $\Rightarrow$ & $140 \%$ & $0.51[0.19 .1 .42]$ \\
\hline Subtotal $(95 \% \mathrm{CI})$ & 143 & 97 & - & $34.9 \%$ & $0.51[0.28,0.94]$ \\
\hline \multicolumn{6}{|c|}{ Total events: 39 (Milinacipran), 34 (SSR:is) } \\
\hline \multicolumn{6}{|c|}{ 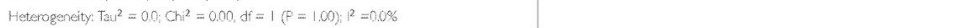 } \\
\hline \multicolumn{6}{|c|}{ Test tor overal effect: $Z=2.17(P=0.030\}$} \\
\hline \multicolumn{6}{|c|}{2 Milnacipran us Funsetine } \\
\hline Gueff $19 \div 8 \mathrm{a}$ & 20200 & $11 / 100$ & & $20.1 \%$ & $0.90[0.41,1.96]$ \\
\hline Lee 20025 & $13 / 39$ & $11 / 31$ & & $14.5 \%$ & $0.91[0,34,245]$ \\
\hline Subtotal $(95 \% \mathrm{CI})$ & 239 & 131 & & $34.6 \%$ & $0.90[0.49,1.67]$ \\
\hline \multicolumn{6}{|c|}{ Total events: 37 (Minacipran). 27 (SSRIs) } \\
\hline \multicolumn{6}{|c|}{ Heterngensity: Tau ${ }^{2}=0.0:\left(h^{2}=0,00\right.$, of $=1(\rho=0,99), 1^{2}=0,0 \%$} \\
\hline \multicolumn{6}{|c|}{ Test tor overal effect: $Z=0.33(p=0.74)$} \\
\hline \multicolumn{6}{|c|}{3 Milinacipran vs Faroxetine } \\
\hline Sechter 2000 & $115 / 449$ & $107 / 153$ & $=-$ & $30.5 \%$ & $1.45[087,2.43]$ \\
\hline Subtotal $(95 \% \mathrm{CI})$ & 149 & 153 & - & $30.5 \%$ & $1.45[0.87,2.43]$ \\
\hline \multicolumn{6}{|c|}{ Total events: 1 IS (Minacipran), 107 (SSPR.lis) } \\
\hline \multicolumn{6}{|c|}{ Hetemgensity not applicable } \\
\hline \multicolumn{6}{|c|}{ Test for overal effect: $Z=1.42(p=0.15)$} \\
\hline Total $(95 \% \mathrm{CI})$ & 531 & 381 & & $100.0 \%$ & $0.86[0.55,1.34]$ \\
\hline \multicolumn{6}{|c|}{ Total events: 187 (Minacipran). 163 (SSF:is) } \\
\hline \multicolumn{6}{|c|}{ Histemgencity: $: \mathrm{Tu}^{2}=0.10 ; \mathrm{Ch}^{2}=6.62 \mathrm{df}=4(\mathrm{p}=0.16): \mathrm{l}^{2}=49 \%$} \\
\hline \multicolumn{6}{|c|}{ Test tor overall effict: $Z=0.68(p=0.50)$} \\
\hline & & & 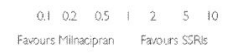 & & \\
\hline
\end{tabular}

Analysis 12.3

Comparison 12 Patients with at least some adverse events (Tolerability), Outcome 3 Milnacipran vs Heterocyclics

Review: Milnacipran versus other antidepressive agents for depression Comparison: 12 Patients with at least some adverse events (Tolerability) Outcome: 3 Milnacipran vs Heterocyclics

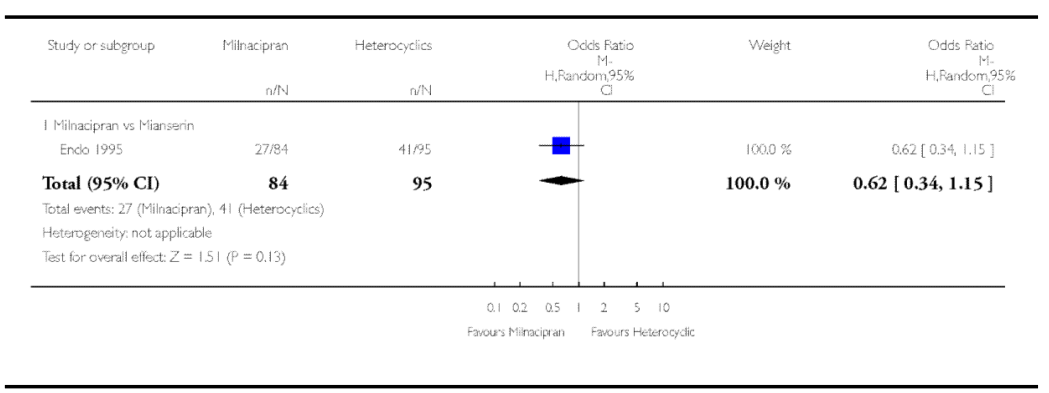




\section{Analysis 13.1}

Comparison 13 Adverse events: Sleepiness/ Drowsiness,

\section{Outcome 1 Milnacipran vs TCAs}

Review: Milnacipran versus other antidepressive agents for depression Comparison: 13 Adverse events: Sleepiness/ Drowsiness

Outcome: 1 Milnacipran vs TCAs

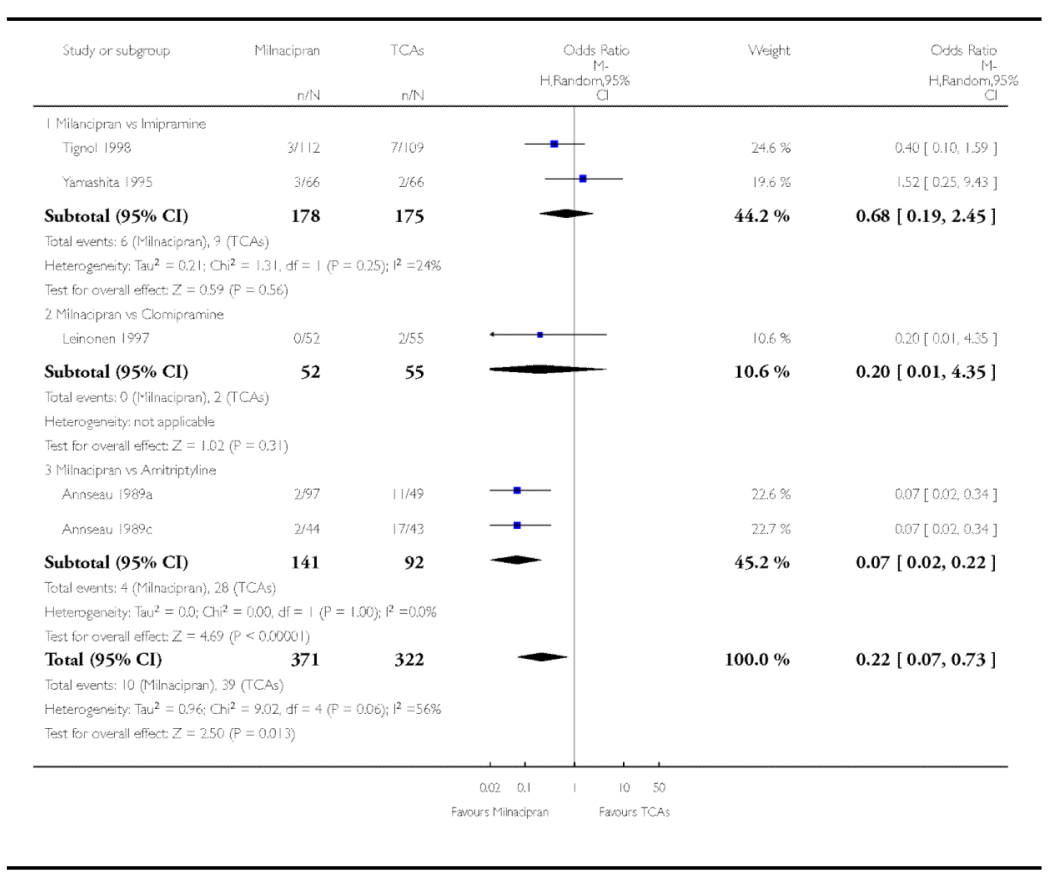




\section{Analysis 13.2}

Comparison 13 Adverse events: Sleepiness/ Drowsiness, Outcome 2 Milancipran vs SSRIs

Review: Milnacipran versus other antidepressive agents for depression Comparison: Milnacipran versus other antidepressive agents for depression Outcome: 2 Milancipran vs SSRIs

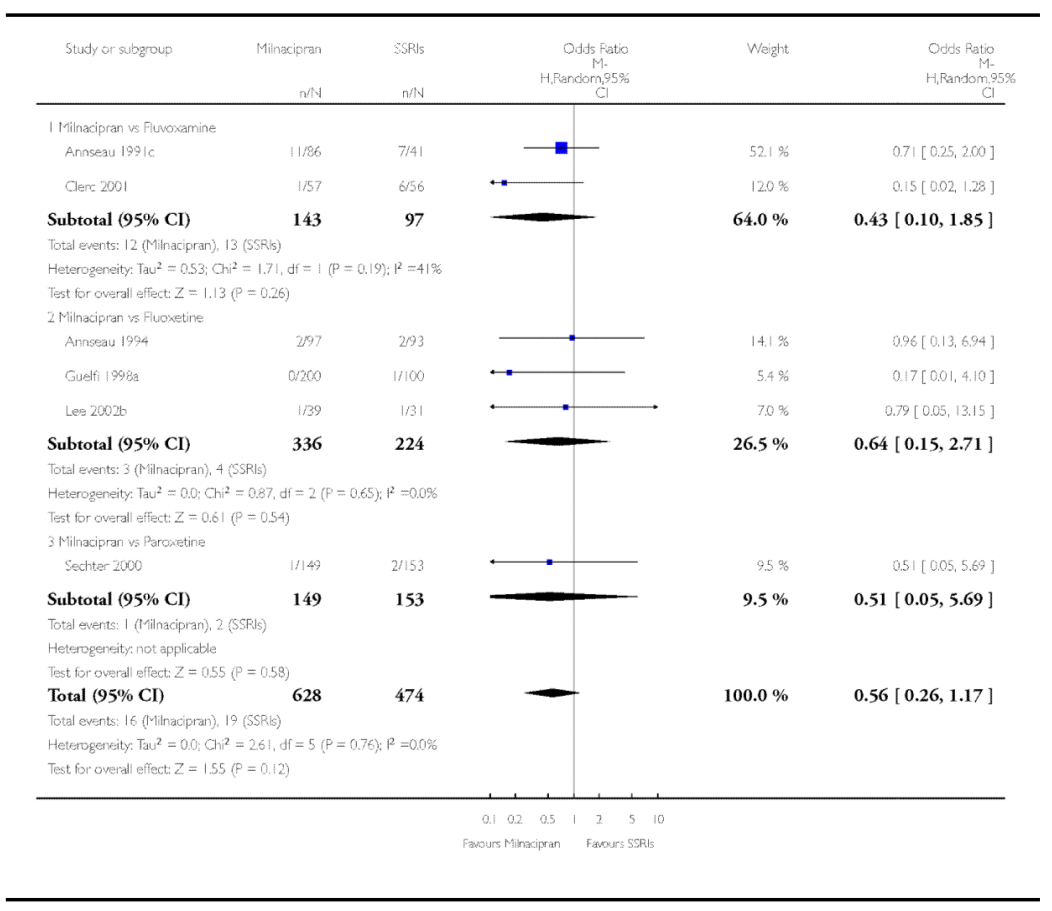

Analysis 13.3

Comparison 13 Adverse events: Sleepiness/ Drowsiness, Outcome 3 Milnacipran vs Heterocyclics

Review: Milnacipran versus other antidepressive agents for depression Comparison: 13 Adverse events: Sleepiness/ Drowsiness

Outcome: 3 Milnacipran vs Heterocyclics

\begin{tabular}{|c|c|c|c|c|c|c|}
\hline Study or subgroup & Minesipran & $\begin{array}{l}\text { Heterocydics } \\
\text { niN }\end{array}$ & \multicolumn{2}{|c|}{$\begin{array}{r}\text { Odds Putio } \\
\text { H.Fiandom } 95 \% \\
\end{array}$} & Weight & $\begin{array}{l}\text { Oddo's Ratio } \\
\text { HFiandom, } \\
\text { Cl }\end{array}$ \\
\hline \multicolumn{7}{|c|}{ I Milancipran vs Mianserin } \\
\hline \multicolumn{7}{|c|}{$\begin{array}{l}\text { Total events: } 5 \text { (Milinacipran), } 22 \text { (Hetsooplics) } \\
\text { Heterogeneity: not applicable } \\
\text { Tost for overal fffiect: } Z=299(P=0.0028)\end{array}$} \\
\hline & & & 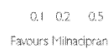 & 2 & & \\
\hline
\end{tabular}


Analysis 14.1

Comparison 14 Adverse events: Insomnia, Outcome 1

Milnacipran vs TCAs

Review: Milnacipran versus other antidepressive agents for depression Comparison: 14 Adverse events: Insomnia

Outcome: 1 Milnacipran vs TCAs

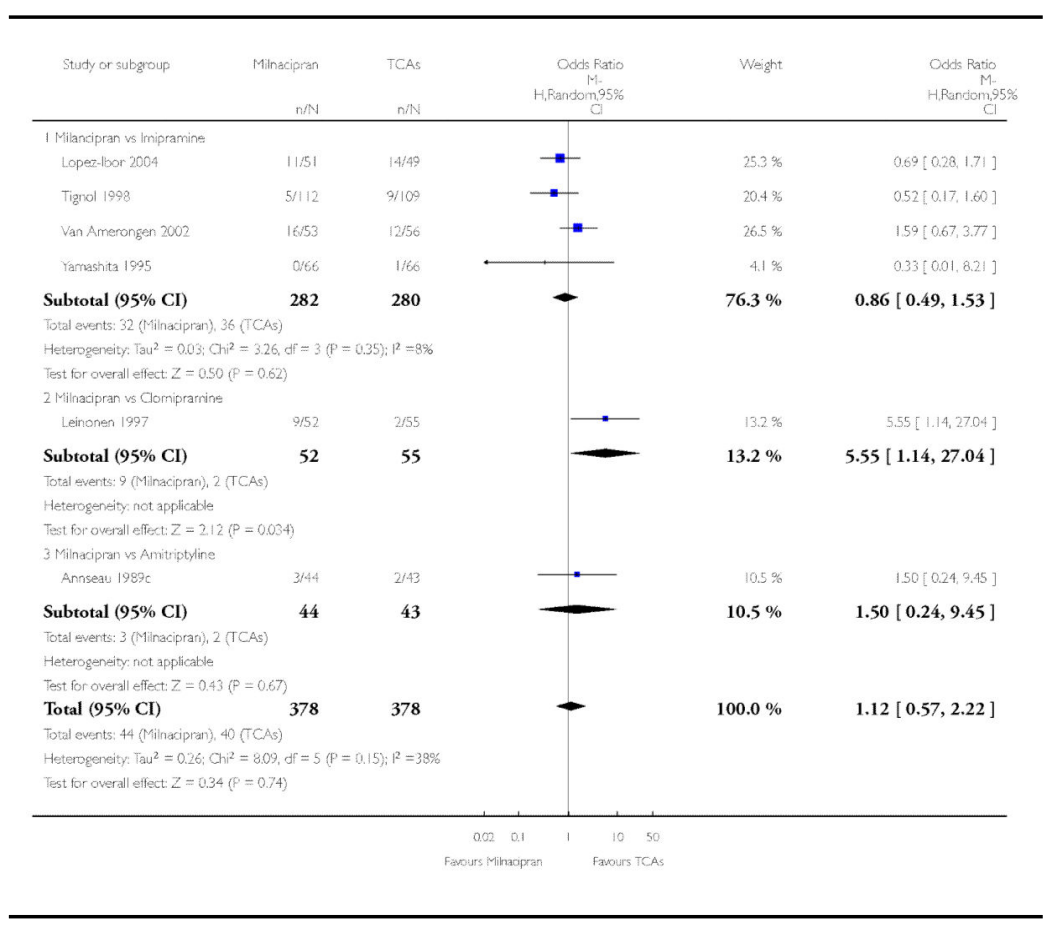


Analysis 14.2

Comparison 14 Adverse events: Insomnia, Outcome 2 Milancipran vs SSRIs

Review: Milnacipran versus other antidepressive agents for depression Comparison: 14 Adverse events: Insomnia

Outcome: 2 Milancipran vs SSRIs

\begin{tabular}{|c|c|c|c|c|c|c|}
\hline Study or subgroup & Millatipran & $\begin{array}{l}\text { SSPR.k } \\
\text { MN: } \\
\end{array}$ & H, Rar & $\begin{array}{l}\text { des Patio } \\
\text { M- } \\
\text { dom } 85 \%\end{array}$ & Weight & $\begin{array}{l}\text { Odds Fietio } \\
\text { M. Fendom } 95 \%\end{array}$ \\
\hline \multicolumn{7}{|c|}{1 Milinacipran us Flivexamins } \\
\hline Annsesau $1991 \mathrm{c}$ & 1286 & $7 / 41$ & - & - & $31.6 \%$ & $0.79[0.28,2.18]$ \\
\hline Cerc 2001 & 0,57 & 1/56 & & & $3.1 \%$ & $0.32[0.01,8.07]$ \\
\hline Subtotal $(95 \% \mathrm{CI})$ & 143 & 97 & 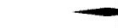 & & $34.8 \%$ & $0.73[0.28,1.92]$ \\
\hline \multirow{2}{*}{\multicolumn{7}{|c|}{ 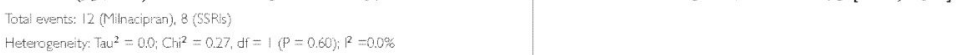 }} \\
\hline & & & & & & \\
\hline \multicolumn{7}{|c|}{ Test far overal efiect $Z=0.65(P=0.52)$} \\
\hline \multicolumn{7}{|c|}{2 Milinacipran vs Fiucoestine } \\
\hline Annseasu 1994 & 599 & $7 / 93$ & $"$ & - & $23.3 \%$ & $0.67[0.20,2.18]$ \\
\hline Guefi 1998 & $7 / 200$ & $(6 / 100$ & $=$ & & $32.8 \%$ & $0.33[0.2,0.89]$ \\
\hline $\operatorname{Lee} 2002 b$ & 0.39 & $2 / 31$ & & & $3.5 \%$ & $0.15[001,3.23]$ \\
\hline Subtotal $(95 \% \mathrm{CI})$ & 336 & 224 & - & & $59.6 \%$ & $0.41[0.20,0.87]$ \\
\hline \multirow{2}{*}{\multicolumn{7}{|c|}{ 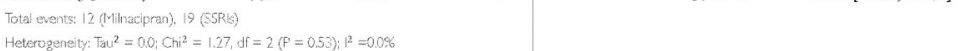 }} \\
\hline & & & & & & \\
\hline \multicolumn{7}{|c|}{ Test for overal effect $Z=2.34(p=0.199)$. } \\
\hline \multicolumn{7}{|c|}{3 Minacipran vs Faroxedine } \\
\hline Sechter 2000 & $1: 149$ & 2453 & & & $5.6 \%$ & $0.51[0.05,5.69]$ \\
\hline Subtotal $(95 \% \mathrm{CI})$ & 149 & 153 & & & $5.6 \%$ & $0.51[0.05,5.69]$ \\
\hline \multicolumn{7}{|c|}{ Total evertits: 1 (Mil inatipran), 2 (SSRRs) } \\
\hline \multicolumn{7}{|c|}{ Heterogeneity: not applicable } \\
\hline \multicolumn{7}{|c|}{ Test for overal effect $Z=0.55(P=0.58)$} \\
\hline Total $(95 \% \mathrm{CI})$ & 628 & 474 & - & & $100.0 \%$ & $0.51[0.29,0.90]$ \\
\hline \multicolumn{7}{|c|}{ Tota events: 25 (Millacipran), 29 (sSR/s) } \\
\hline \multicolumn{7}{|c|}{ Heterogene:ty: Tau $^{2}=0, \mathrm{Ch}^{2}=2.36, \mathrm{di}=5\langle\mathrm{P}=0.80\rangle, \mathrm{R}^{2}=0.0 \%$} \\
\hline \multicolumn{7}{|c|}{ Test for overal effect: $Z=232(\mathrm{P}=01020)$} \\
\hline & & & 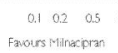 & $\begin{array}{l}2510 \\
\text { Farars SSPS }\end{array}$ & & \\
\hline
\end{tabular}

Analysis 14.3

Comparison 14 Adverse events: Insomnia, Outcome 3 Milnacipran vs Heterocyclics

Review: Milnacipran versus other antidepressive agents for depression Comparison: 14 Adverse events: Insomnia Outcome: 3 Milnacipran vs Heterocyclics

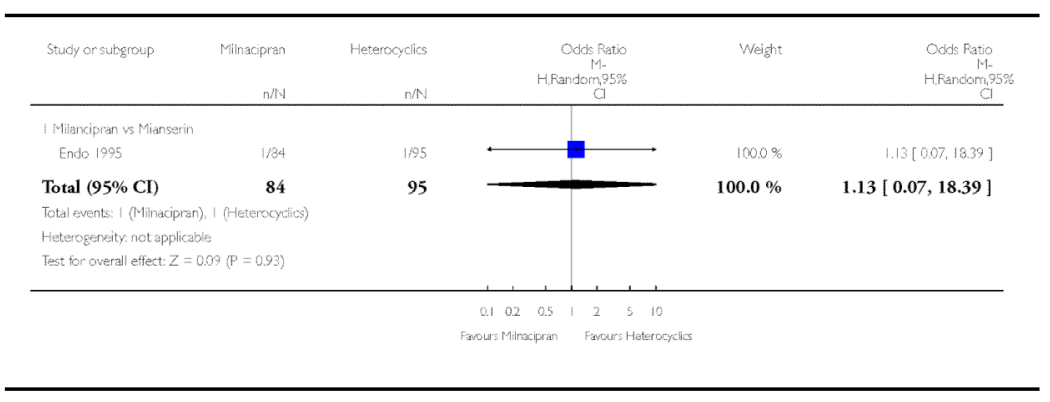


Analysis 15.1

Comparison 15 Adverse events: Dry mouth, Outcome 1 Milnacipran vs TCAs

Review: Milnacipran versus other antidepressive agents for depression Comparison: 15 Adverse events: Dry mouth Outcome: 1 Milnacipran vs TCAs

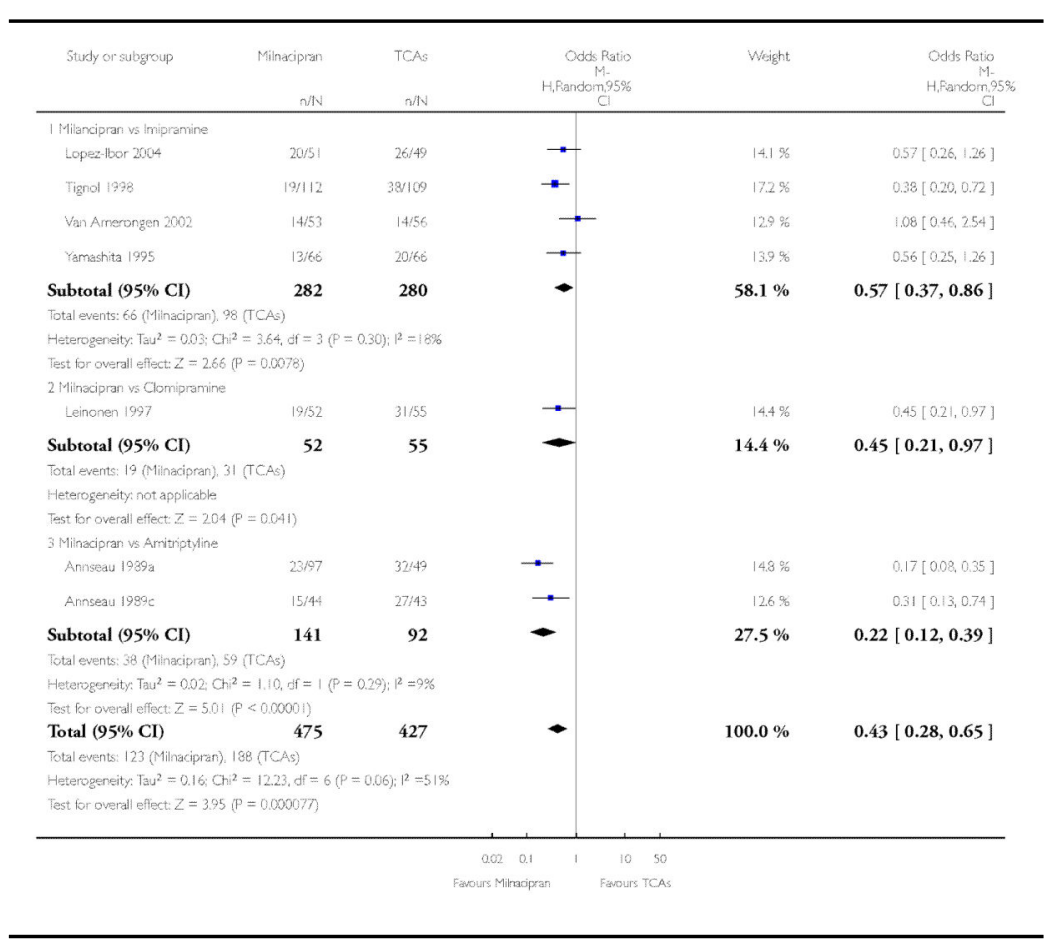


Analysis 15.2

Comparison 15 Adverse events: Dry mouth, Outcome 2 Milancipran vs SSRIs

Review: Milnacipran versus other antidepressive agents for depression Comparison: 15 Adverse events: Dry mouth

Outcome: 2 Milancipran vs SSRIs

\begin{tabular}{|c|c|c|c|c|c|}
\hline Study or subgroup & $\begin{array}{r}\text { Milinacipran } \\
\text { n/N }\end{array}$ & SSP.is & $\begin{array}{r}\text { Oods Patio } \\
\text { H,Random } 95 \% \\
\text { Cl }\end{array}$ & Weght & $\begin{array}{l}\text { Odds Ratio } \\
\text { M. Parsom, } 95 \% \\
\text { a } \%\end{array}$ \\
\hline \multicolumn{6}{|c|}{1 Minacipran vas Fuvoxamine: } \\
\hline Annseav $199 \mathrm{ic}$ & 25186 & 1241 & $\rightarrow$ & $44.7 \%$ & $0.99[0.44,2.24]$ \\
\hline Cerc 2001 & $3 / 57$ & 5,56 & - & $13.6 \%$ & $0.57[0.13,2.49]$ \\
\hline Subtotal $(95 \% \mathrm{CI})$ & 143 & 97 & & $58.4 \%$ & $0.87[0.42,1.78]$ \\
\hline \multicolumn{6}{|c|}{ Total events: 28 (Milihacipran), 17 (SSPls) } \\
\hline \multicolumn{6}{|c|}{ 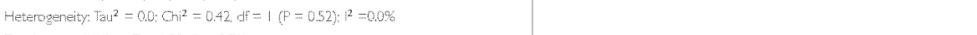 } \\
\hline \multicolumn{6}{|c|}{ Tess for overall efect: $Z=0.38(P=0.70)$} \\
\hline \multicolumn{6}{|c|}{2 Milnacipran us Fluovetire } \\
\hline Annseau 1994 & $13 / 97$ & 10993 & $=$ & $38.8 \%$ & $1.28[0.53,3.09]$ \\
\hline Lee $2002 \mathrm{~b}$ & $1 / 39$ & $0 / 31$ & $\longrightarrow$ & $29 \%$ & $2.45[0.10,62.36]$ \\
\hline Subtotal $(95 \% \mathrm{CI})$ & 136 & 124 & - & $41.6 \%$ & $1.34[0.58,3.13]$ \\
\hline \multicolumn{6}{|c|}{ Total events: 14 (Milhacipran), 10 (SSRRs) } \\
\hline \multicolumn{6}{|c|}{ Heterogencity: Tau ${ }^{2}=0,0 ; 0 i^{2}=0.14$, of $=1\left(p=0,70 ; 2^{2}=0.0 \%\right.$} \\
\hline \multicolumn{6}{|c|}{ Test for overall effect: $Z=0.68$ (P $=0.50\rangle$} \\
\hline Total $(95 \% \mathrm{CI})$ & 279 & 221 & & $100.0 \%$ & $1.04[0.60,1.80]$ \\
\hline \multicolumn{6}{|c|}{ Total events: 42 (Milinacipran), 27 (SSFilis) } \\
\hline \multicolumn{6}{|c|}{ 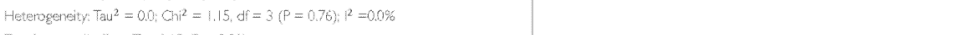 } \\
\hline \multicolumn{6}{|c|}{ Test for overall effect: $Z=0.15(p=0.92)$} \\
\hline & & & 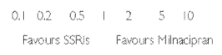 & & \\
\hline
\end{tabular}

Analysis 15.3

Comparison 15 Adverse events: Dry mouth, Outcome 3 Milnacipran vs Heterocyclics

Review: Milnacipran versus other antidepressive agents for depression Comparison: 15 Adverse events: Dry mouth

Outcome: 3 Milnacipran vs Heterocyclics

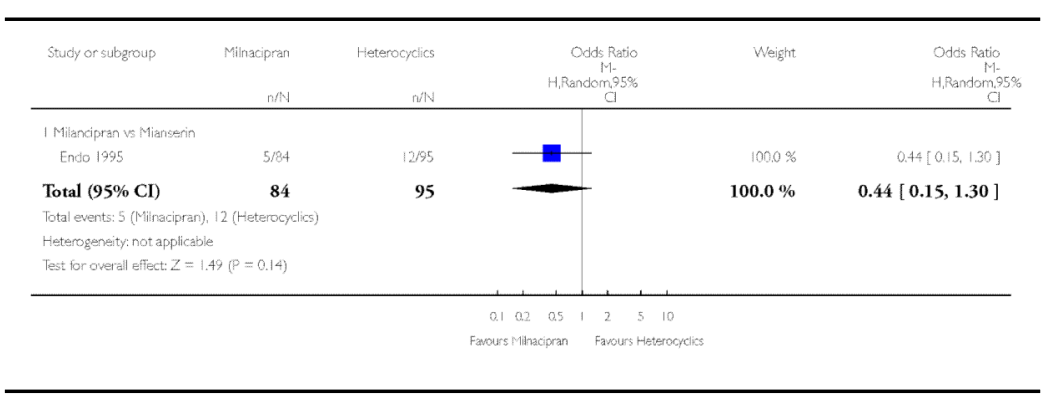


Analysis 16.1

Comparison 16 Adverse events: Constipation, Outcome 1 Milnacipran vs TCAs

Review: Milnacipran versus other antidepressive agents for depression Comparison: 16 Adverse events: Constipation

Outcome: 1 Milnacipran vs TCAs

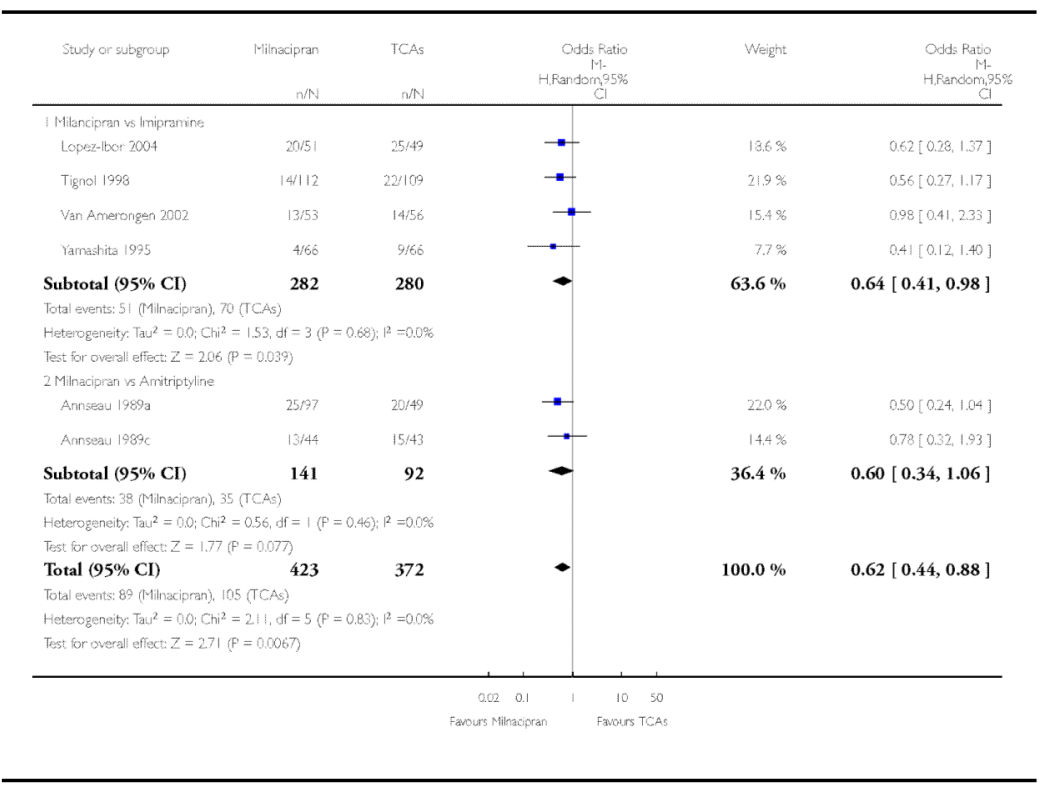




\section{Analysis 16.2}

Comparison 16 Adverse events: Constipation, Outcome 2 Milancipran vs SSRIs

Review: Milnacipran versus other antidepressive agents for depression Comparison: 16 Adverse events: Constipation

Outcome: 2 Milancipran vs SSRIs

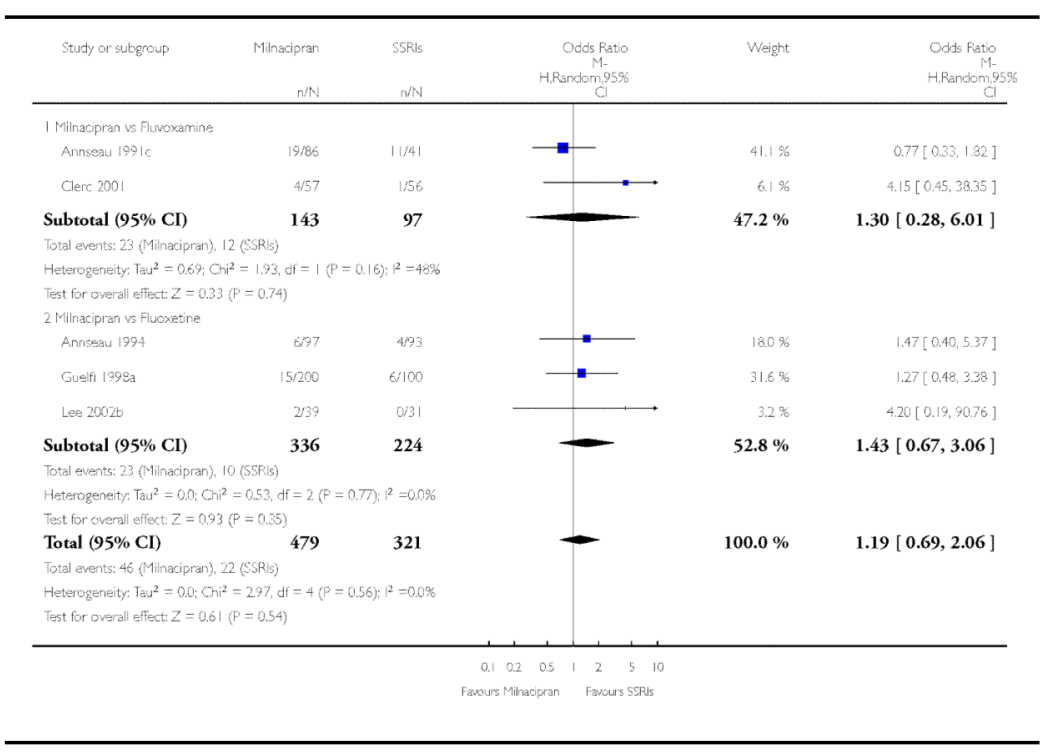

Analysis 16.3

Comparison 16 Adverse events: Constipation, Outcome 3 Milnacipran vs Heterocyclics

Review: Milnacipran versus other antidepressive agents for depression Comparison: 16 Adverse events: Constipation Outcome: 3 Milnacipran vs Heterocyclics

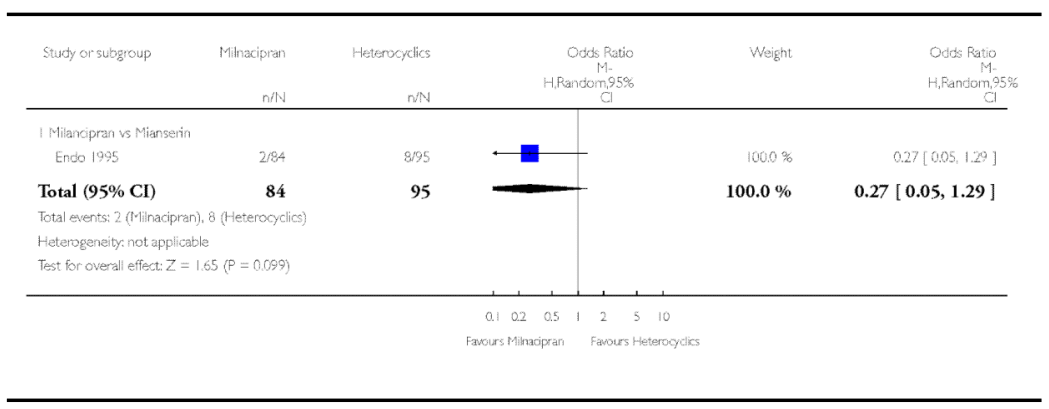




\section{Analysis 17.1}

Comparison 17 Adverse events: Urination problems, Outcome 1 Milnacipran vs TCAs

Review: Milnacipran versus other antidepressive agents for depression Comparison: 17 Adverse events: Urination problems Outcome: 1 Milnacipran vs TCAs

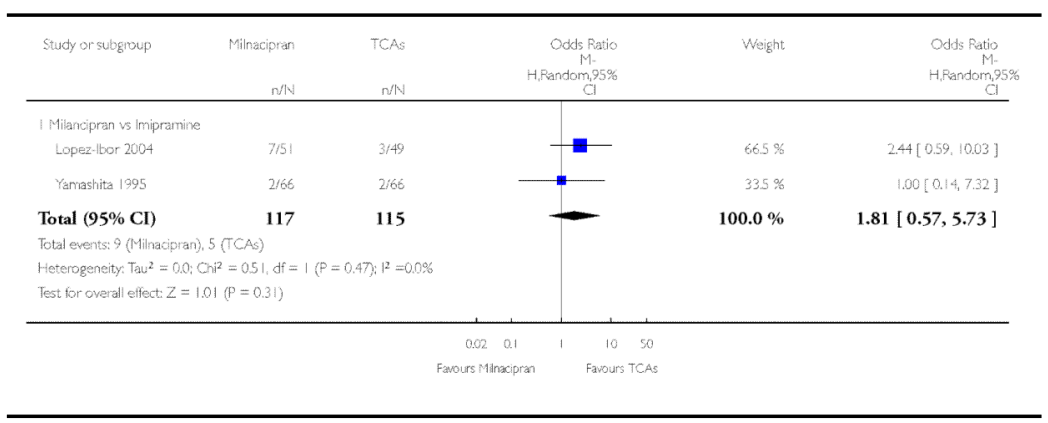

Analysis 17.2

Comparison 17 Adverse events: Urination problems, Outcome 2 Milancipran vs SSRIs

Review: Milnacipran versus other antidepressive agents for depression Comparison: 17 Adverse events: Urination problems Outcome: 2 Milancipran vs SSRIs

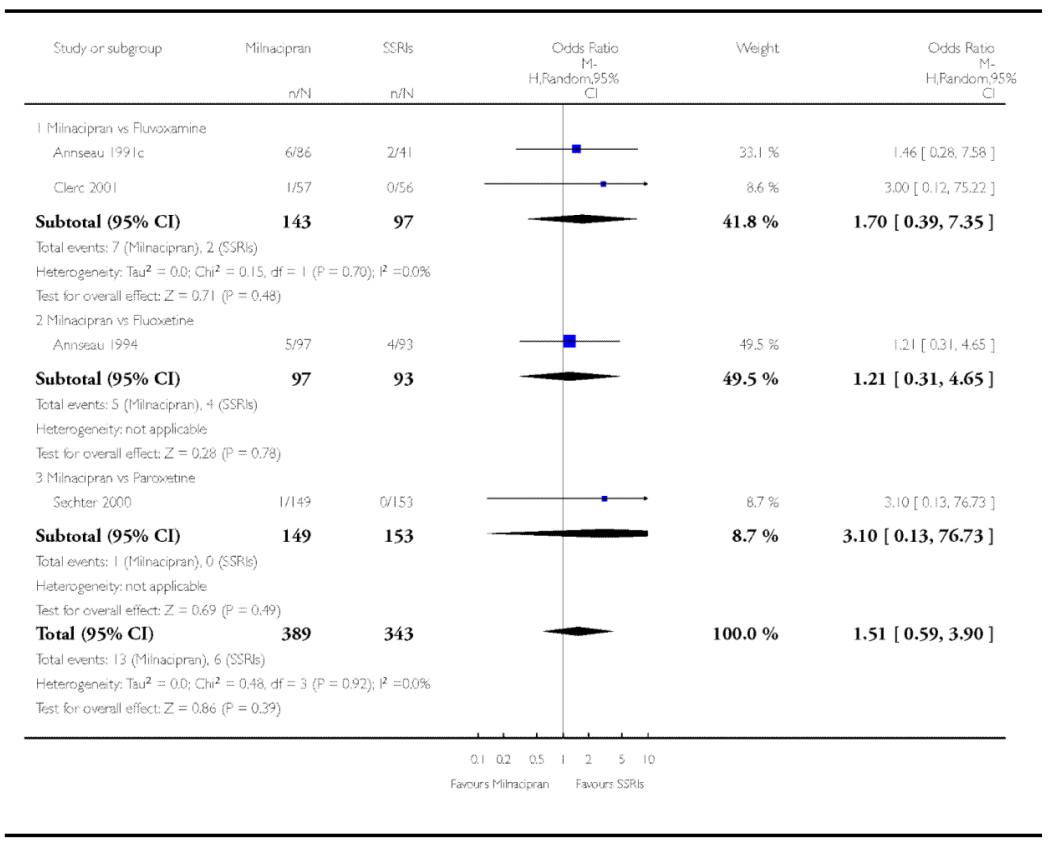




\section{Analysis 17.3}

Comparison 17 Adverse events: Urination problems, Outcome 3 Milnacipran vs Heterocyclics

Review: Milnacipran versus other antidepressive agents for depression Comparison: 17 Adverse events: Urination problems

Outcome: 3 Milnacipran vs Heterocyclics

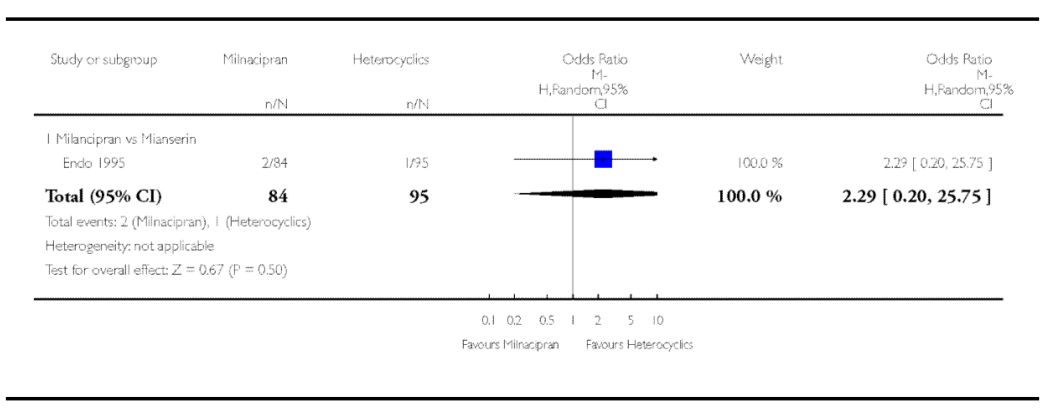

Analysis 18.1

Comparison 18 Adverse events: Hypotention, Outcome 1 Milnacipran vs TCAs

Review: Milnacipran versus other antidepressive agents for depression Comparison: 18 Adverse events: Hypotention

Outcome: 1 Milnacipran vs TCAs

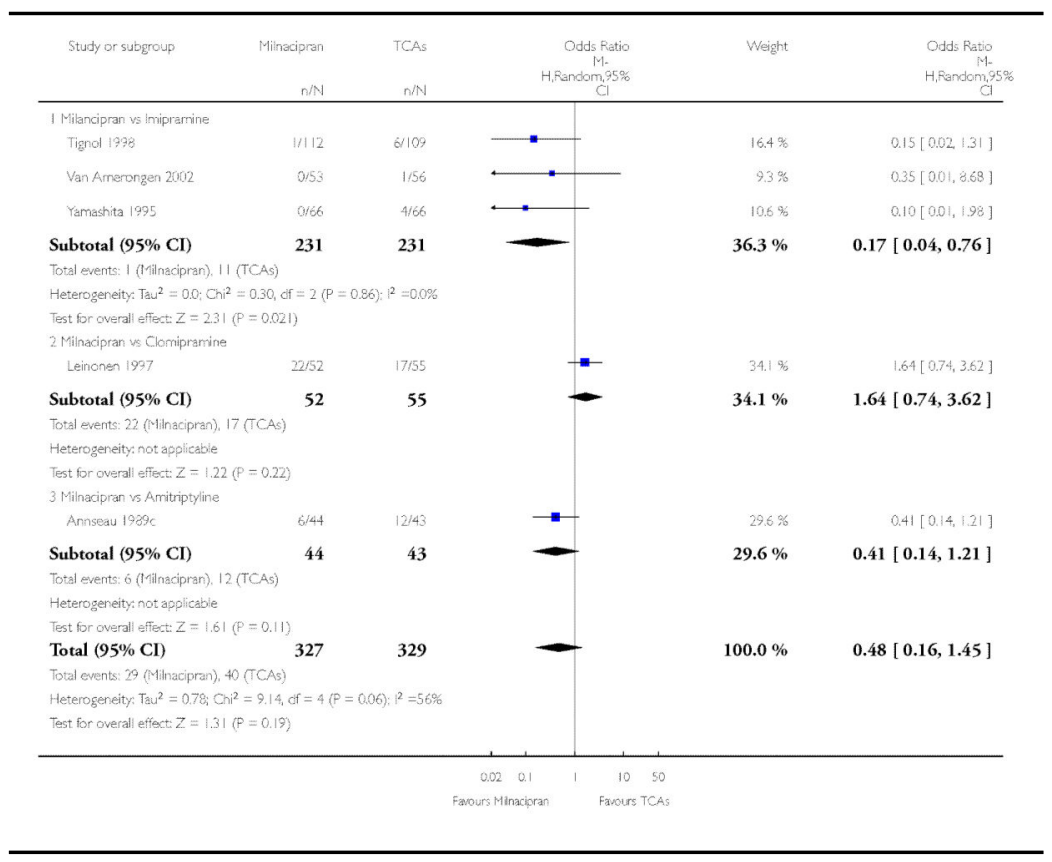




\section{Analysis 18.2}

Comparison 18 Adverse events: Hypotention, Outcome 2 Milancipran vs SSRIs

Review: Milnacipran versus other antidepressive agents for depression Comparison: 18 Adverse events: Hypotention

Outcome: 2 Milancipran vs SSRIs

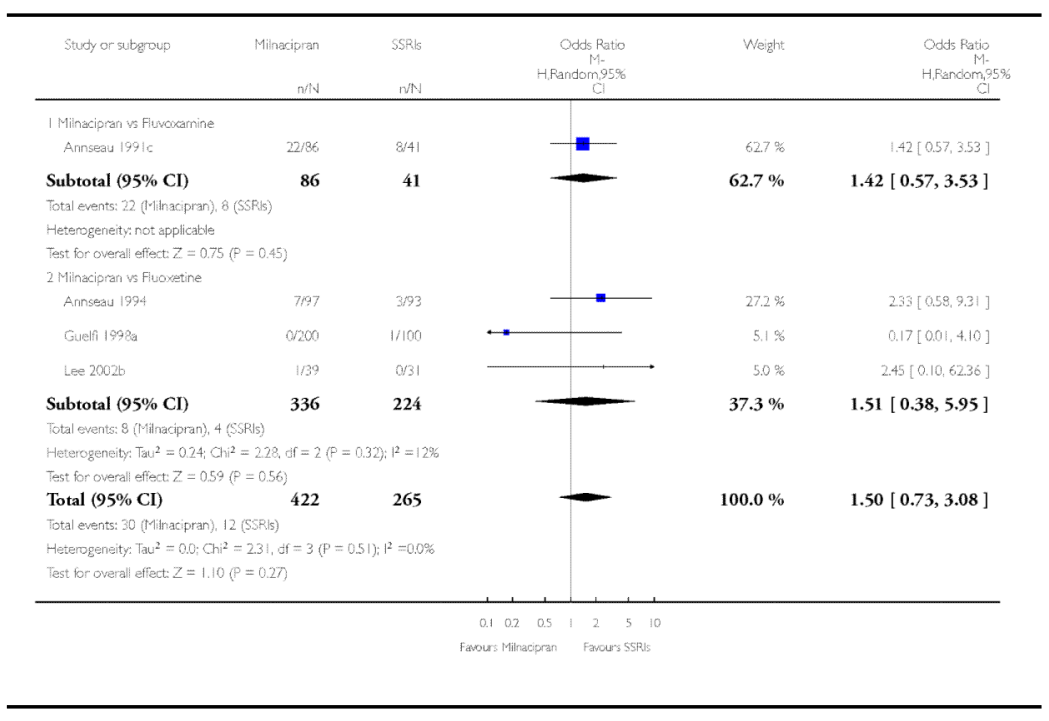

Analysis 18.3

Comparison 18 Adverse events: Hypotention, Outcome 3 Milnacipran vs Heterocyclics

Review: Milnacipran versus other antidepressive agents for depression Comparison: 18 Adverse events: Hypotention

Outcome: 3 Milnacipran vs Heterocyclics

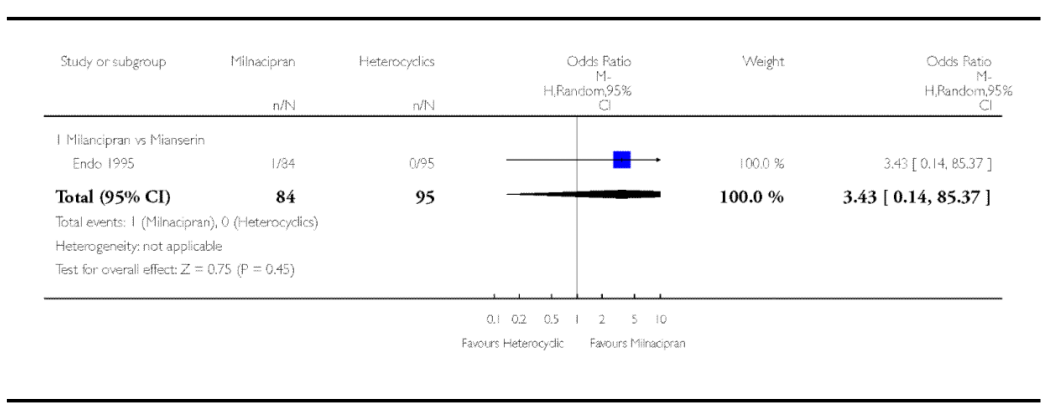




\section{Analysis 19.1}

Comparison 19 Adverse events: Agitaion/ anxiety, Outcome 1 Milnacipran vs TCAs

Review: Milnacipran versus other antidepressive agents for depression Comparison: 19 Adverse events: Agitaion/ anxiety Outcome: 1 Milnacipran vs TCAs

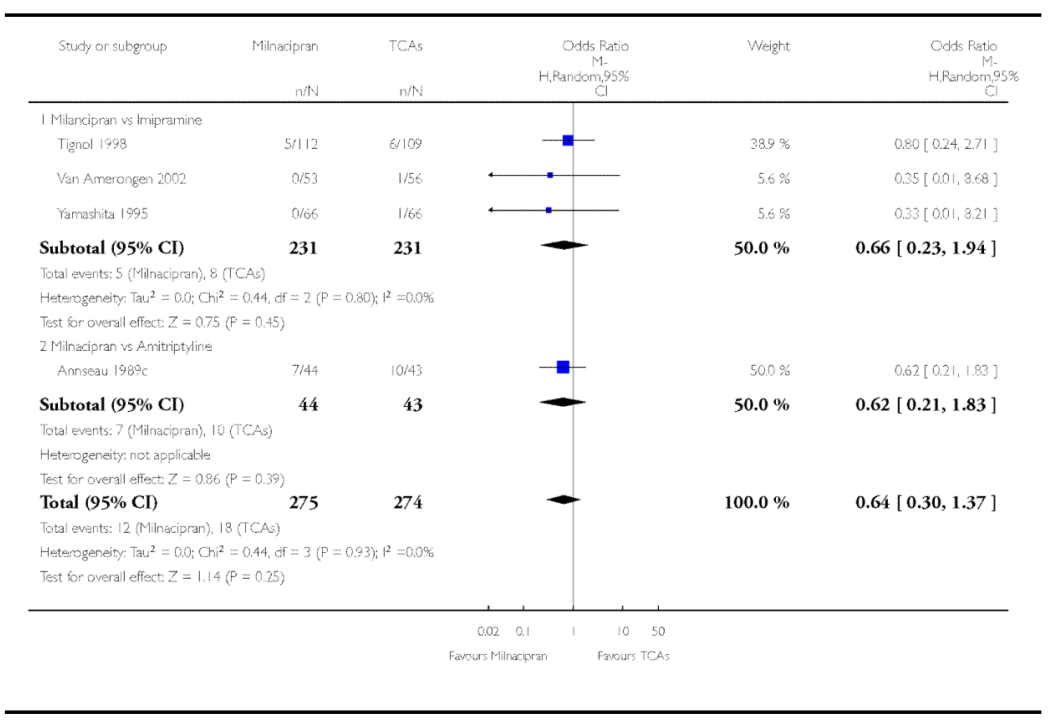




\section{Analysis 19.2}

Comparison 19 Adverse events: Agitaion/ anxiety, Outcome 2 Milancipran vs SSRIs

Review: Milnacipran versus other antidepressive agents for depression Comparison: 19 Adverse events: Agitaion/ anxiety

Outcome: 2 Milancipran vs SSRIs

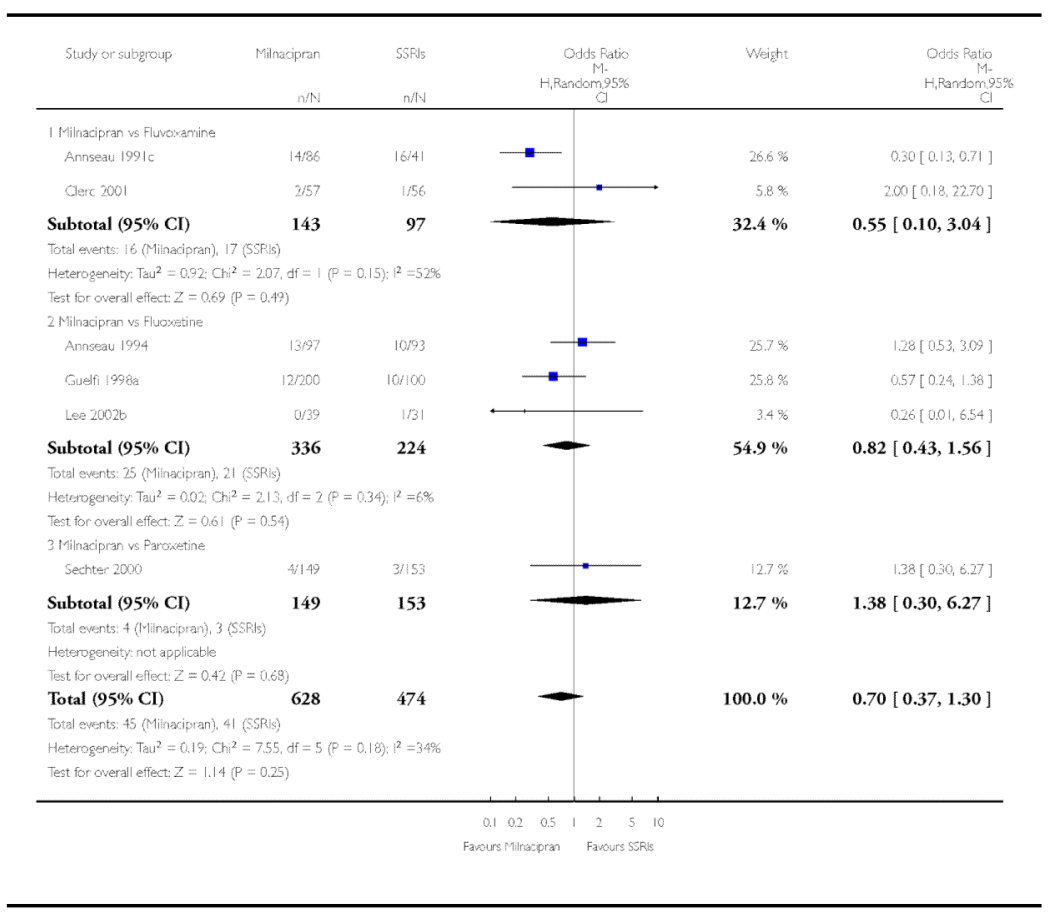

Analysis 19.3

Comparison 19 Adverse events: Agitaion/ anxiety, Outcome 3 Milnacipran vs Heterocyclics

Review: Milnacipran versus other antidepressive agents for depression Comparison: 19 Adverse events: Agitaion/anxiety Outcome: 3 Milnacipran vs Heterocyclics

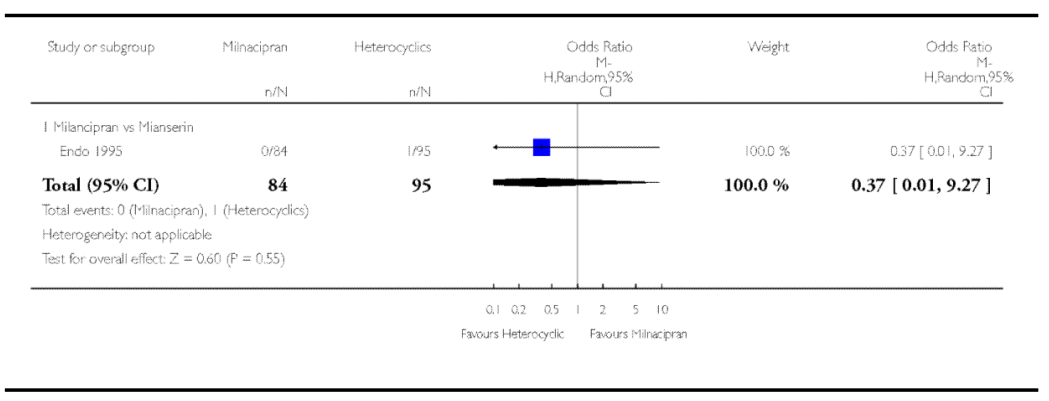




\section{Analysis 20.1}

Comparison 20 Adverse events: Suicide wishes/ gestures/ attempts, Outcome 1 Milnacipran vs TCAs

Review: Milnacipran versus other antidepressive agents for depression Comparison: 20 Adverse events: Suicide wishes/ gestures/ attempts Outcome: 1 Milnacipran vs TCAs

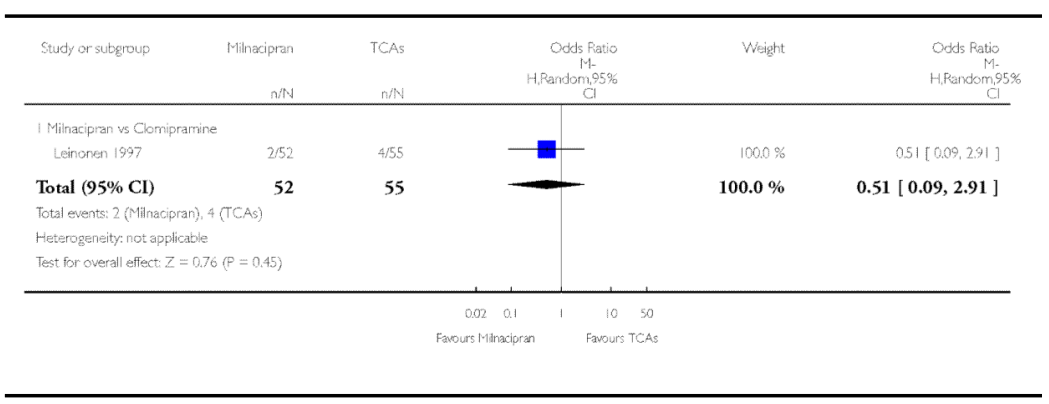

Analysis 20.2

Comparison 20 Adverse events: Suicide wishes/ gestures/ attempts, Outcome 2 Milancipran vs SSRIs

Review: Milnacipran versus other antidepressive agents for depression Comparison: 20 Adverse events: Suicide wishes/gestures/ attempts Outcome: 2 Milancipran vs SSRIs

\begin{tabular}{|c|c|c|c|c|c|}
\hline Study or subgroup & Minaripran & $\begin{array}{l}\text { SSRIS } \\
\text { INA }\end{array}$ & $\begin{array}{l}\text { Odds Ratio } \\
\text { M- } \\
\text { HiRandom, } 5 \% \\
\text { d }\end{array}$ & Weight & $\begin{array}{l}\text { Odds Ratio } \\
\text { H.Pandom } 95 \text { s. } \\
\text { Cl }\end{array}$ \\
\hline \multicolumn{6}{|c|}{ I Minacipran vs Fluoxetitre } \\
\hline \multicolumn{6}{|c|}{ 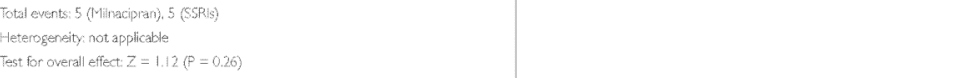 } \\
\hline & & & 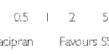 & & \\
\hline
\end{tabular}




\section{Analysis 21.1}

Comparison 21 Adverse events:Completed suicide, Outcome 1 Milancipran vs SSRIs

Review: Milnacipran versus other antidepressive agents for depression Comparison: 21 Adverse events:Completed suicide Outcome: 1 Milancipran vs SSRIs

\begin{tabular}{|c|c|c|c|c|c|}
\hline Study or subgroup & $\begin{array}{l}\text { Militadipran } \\
\text { n/N }\end{array}$ & $\begin{array}{l}\text { SSPls } \\
n / N\end{array}$ & $\begin{array}{c}\text { Odds Patio } \\
\text { M. } \\
\text { H.Ranciom, } 95 \% \\
\text { a }\end{array}$ & Weight & $\begin{array}{l}\text { Odds Patio } \\
\text { M.Rendom,95\% } \\
\text { a }\end{array}$ \\
\hline \multicolumn{6}{|c|}{1 Minasipran vs fluoxetine } \\
\hline \multicolumn{6}{|c|}{ 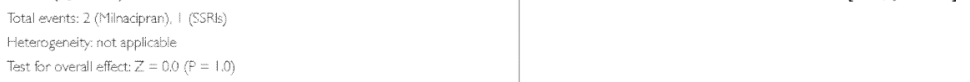 } \\
\hline & & & 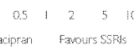 & & \\
\hline
\end{tabular}

Analysis 22.1

Comparison 22 Adverse events: Vomitting/ nausea, Outcome 1 Milnacipran vs TCAs

Review: Milnacipran versus other antidepressive agents for depression Comparison: 22 Adverse events: Vomitting/ nausea Outcome: 1 Milnacipran vs TCAs

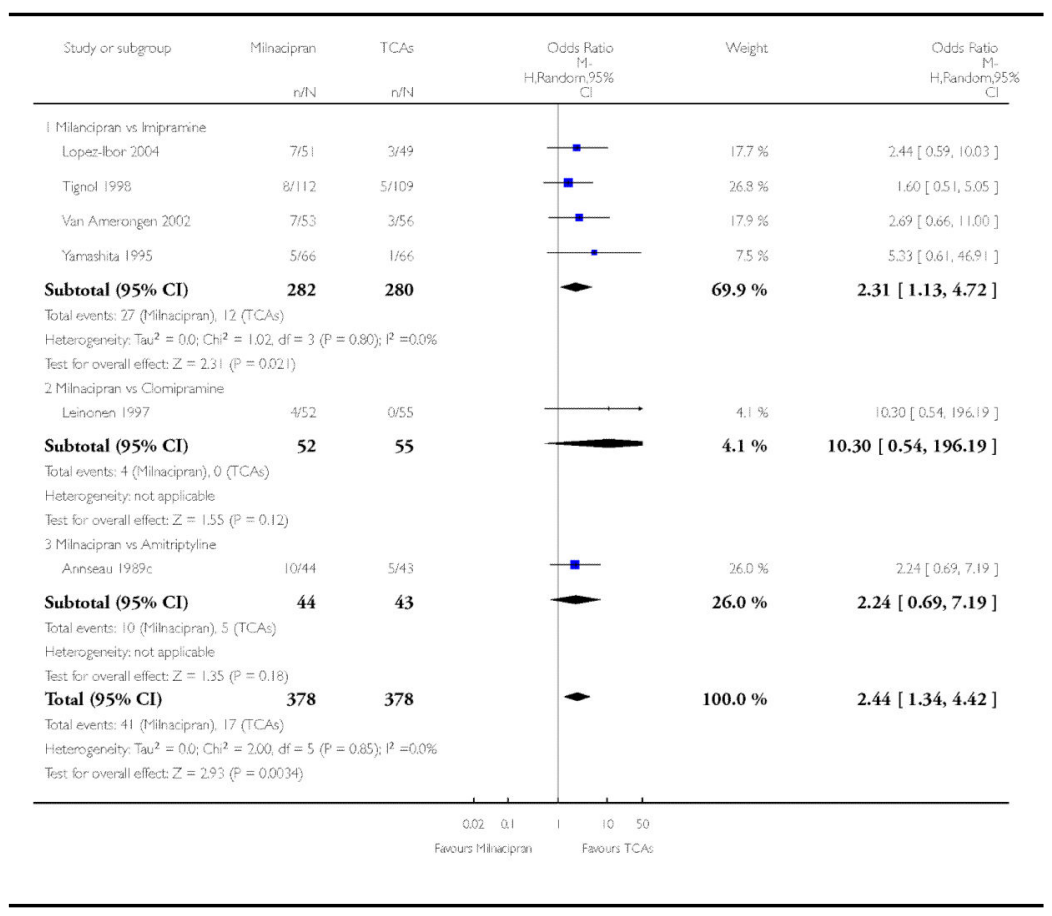




\section{Analysis 22.2}

Comparison 22 Adverse events: Vomitting/ nausea, Outcome 2 Milancipran vs SSRIs

Review: Milnacipran versus other antidepressive agents for depression Comparison: 22 Adverse events: Vomitting/ nausea Outcome: 2 Milancipran vs SSRIs

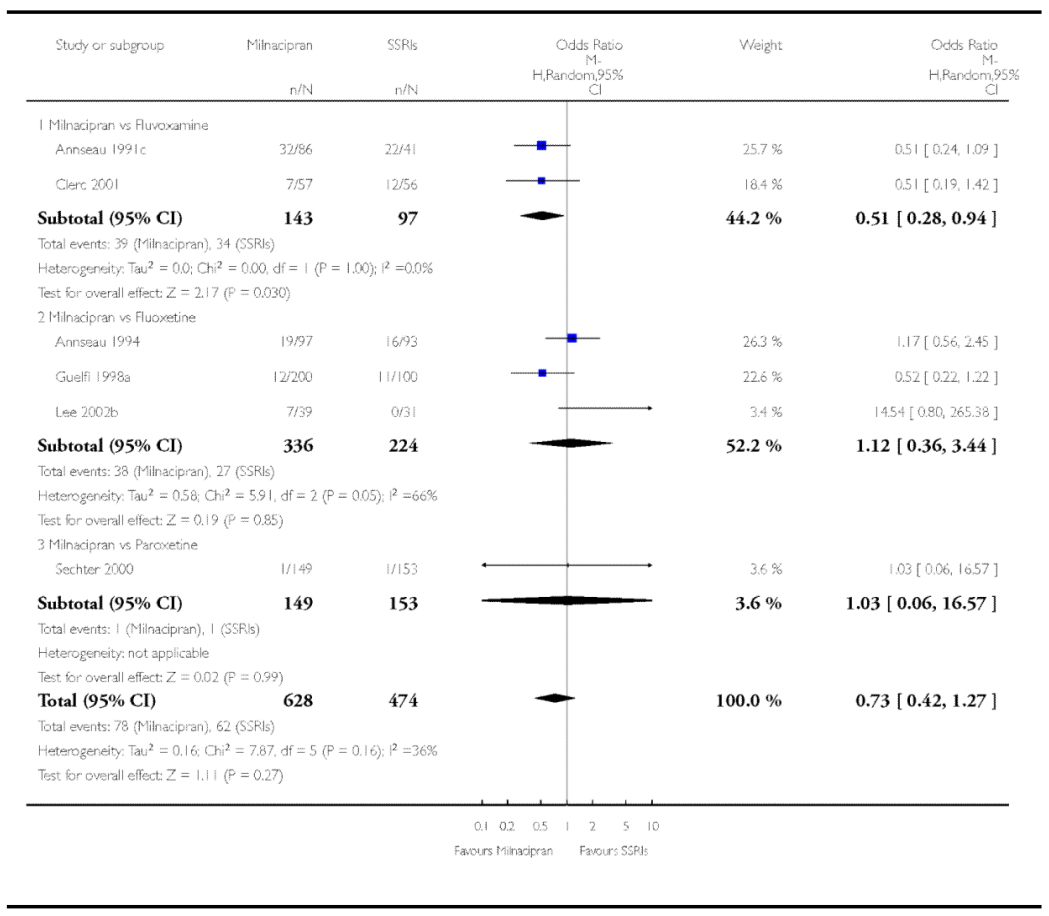

Analysis 22.3

Comparison 22 Adverse events: Vomitting/ nausea, Outcome 3 Milnacipran vs Heterocyclics

Review: Milnacipran versus other antidepressive agents for depression Comparison: 22 Adverse events: Vomitting/ nausea Outcome: 3 Milnacipran vs Heterocyclics

\begin{tabular}{|c|c|c|c|c|c|c|}
\hline Study or subzroup & $\begin{array}{r}\text { Milinacipran } \\
\text { ndN }\end{array}$ & $\begin{array}{r}\text { Heterocydics } \\
\text { MN }\end{array}$ & \multicolumn{2}{|c|}{$\begin{array}{l}\text { Odds Fiato } \\
\text { M. } \\
\text { H,Random95\% } \\
\end{array}$} & Weight & $\begin{array}{l}\text { Odds Rato } \\
\text { M. Random.95\% } \\
\text { CI }\end{array}$ \\
\hline \multicolumn{7}{|c|}{1 Milancipran vis Mianserin } \\
\hline Endo 1995 & $5 / 84$ & 1975 & & $F$ & $1000 \%$ & $5.95[0.63 .5199]$ \\
\hline Total $(95 \% \mathrm{Cl})$ & 84 & 95 & & - & $100.0 \%$ & $5.95[0.68,51.99]$ \\
\hline \multirow{2}{*}{\multicolumn{7}{|c|}{$\begin{array}{l}\text { Total events: } 5 \text { (Milnacipran), I (Hetreocydics) } \\
\text { Heterogenaity not applicabis }\end{array}$}} \\
\hline & & & & & & \\
\hline \multicolumn{7}{|c|}{ Test for overall effect: $Z=1.61 \quad(P=0.11)$} \\
\hline & & & $\begin{array}{l}0.5 \\
\text { occlic }\end{array}$ & $\begin{array}{l}2510 \\
\text { Fuscurs Miraciparan }\end{array}$ & & \\
\hline
\end{tabular}


Analysis 23.1

Comparison 23 Adverse events: Diarrhoea, Outcome 1

Milnacipran vs TCAs

Review: Milnacipran versus other antidepressive agents for depression Comparison: 23 Adverse events: Diarrhoea

Outcome: 1 Milnacipran vs TCAs

\begin{tabular}{|c|c|c|c|c|c|c|}
\hline Study or subgoup & $\begin{array}{l}\text { Milhacipran } \\
\text { ni/N } \\
\end{array}$ & $\begin{array}{l}\text { TCAs } \\
\text { MN }\end{array}$ & & $\begin{array}{l}\text { Odds Retio } \\
\text { M. } \\
\text { H,Random } 95 \% \\
\end{array}$ & Weight & 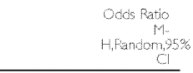 \\
\hline \multicolumn{7}{|l|}{ I Milankipran vo imipramine } \\
\hline Tignd 1990 & $2 / 12$ & $6 / 09$ & & & $35.5 \%$ & $0.31[0,06,1,58]$ \\
\hline $\operatorname{Var}$ Arretongen 2002 & 0,53 & $1 / 56$ & & - & $15.3 \%$ & $0.35[0.01,8.63]$ \\
\hline Yamashitata 1995 & 166 & 0,66 & & $\longrightarrow$ & $15.4 \%$ & $3.05[0.12,76.13]$ \\
\hline Subtotal $(95 \% \mathrm{CI})$ & 231 & 231 & & 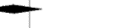 & $66.3 \%$ & $0.47[0.12,1.75]$ \\
\hline \multicolumn{7}{|c|}{ Total everts: 3 (Minacipran), 7 (TCAss) } \\
\hline \multicolumn{7}{|c|}{ Heterogeneity Tau $^{2}=0.0 ; \mathrm{Ch}^{2}=1.58$, of $=2(p=0.45): 1^{2}=0.0 \%$} \\
\hline \multicolumn{7}{|c|}{ Test for overall sffect: $Z=1.13(p=0.26)$} \\
\hline \multicolumn{7}{|c|}{2 Milhacipran ws Conipramine } \\
\hline Leinonen 1997 & $2 / 52$ & 0,55 & & 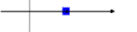 & $16.6 \%$ & $5.50[0.26,117.22]$ \\
\hline Subtotal $(95 \% \mathrm{CI})$ & 52 & 55 & & & $16.6 \%$ & $5.50[0.26,117.22]$ \\
\hline \multicolumn{7}{|c|}{ Total events: 2 (Minacip an), 0 (TCAs) } \\
\hline \multicolumn{7}{|c|}{ Heterogenesty. not applicable } \\
\hline \multicolumn{7}{|c|}{ Test for overall sffsct: $Z=1.09(p=0.28)$} \\
\hline \multicolumn{7}{|c|}{3 Milhacipran vs Amitriptyline } \\
\hline Amnseau 19896 & $3 / 44$ & $0 / 43$ & & & $17.1 \%$ & $7.34[03 \%, 146.43]$ \\
\hline Subtotal $(95 \% \mathrm{CI})$ & 44 & 43 & & & $17.1 \%$ & $7.34[0.37,146.43]$ \\
\hline \multicolumn{7}{|c|}{ Total exents: 3 (Minacipran, 0 (TCAs) } \\
\hline \multicolumn{7}{|c|}{ Heterogenenty not applicable } \\
\hline \multicolumn{7}{|c|}{ Test tor overall effect: $Z=1.30(p=0.19)$} \\
\hline Total $(95 \% \mathrm{CI})$ & 327 & 329 & & - & $100.0 \%$ & $1.24[0.29,5.29]$ \\
\hline \multicolumn{7}{|c|}{ Total exent: 8 (Minadipran), 7 (TCAs) } \\
\hline \multicolumn{7}{|c|}{ Heterogenesty, $: \mathrm{Tat}^{2}=0.25 ; \mathrm{Ch}^{2}=5.81, \mathrm{df}=4(\mathrm{P}=0.21) ; \mathrm{R}^{2}=3196$} \\
\hline \multicolumn{7}{|c|}{ Test for overall sffect: $Z=0.30(P=0.77)$} \\
\hline & & & $\begin{array}{c}002.1 \\
\text { Farcurs limadipran }\end{array}$ & $\begin{array}{l}1050 \\
105 \text { Favors TCAS }\end{array}$ & & \\
\hline
\end{tabular}


Analysis $\mathbf{2 3 . 2}$

Comparison 23 Adverse events: Diarrhoea, Outcome 2

Milancipran vs SSRIs

Review: Milnacipran versus other antidepressive agents for depression Comparison: 23 Adverse events: Diarrhoea

Outcome: 2 Milancipran vs SSRIs

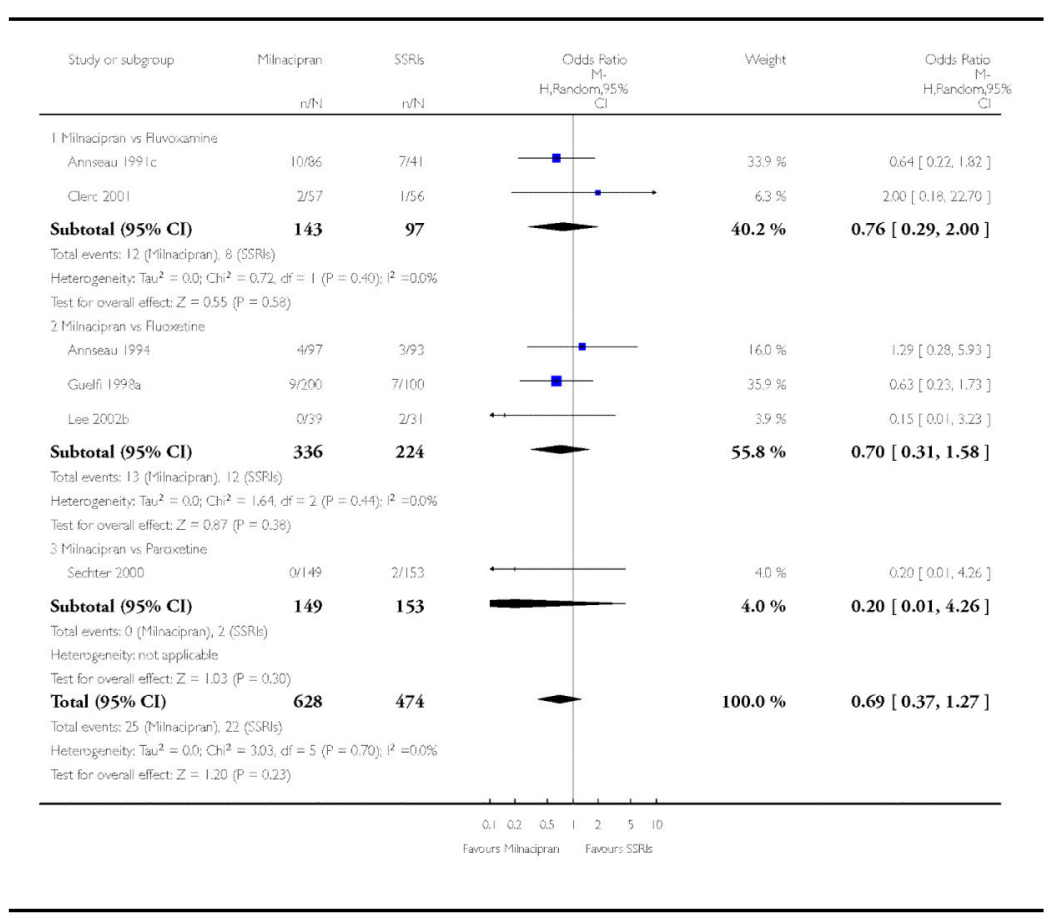




\section{Analysis 24.1}

Comparison 24 Subgroup analysis: Response at early phase (1-4 weeks)-High dose milnacipran, Outcome 1 vs TCAs

Review: Milnacipran versus other antidepressive agents for depression Comparison: 24 Subgroup analysis: Response at early phase (1-4 weeks)-High dose milnacipran

Outcome: 1 vs TCAs

\begin{tabular}{|c|c|c|c|c|c|}
\hline Study or subgroup & $\begin{array}{r}\text { Miracipran } \\
\text { nNN } \\
\end{array}$ & $\begin{array}{l}\text { TCAS } \\
\text { nN } \\
\end{array}$ & 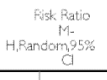 & Weight & 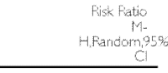 \\
\hline \multicolumn{6}{|l|}{ I ws Comipramine } \\
\hline 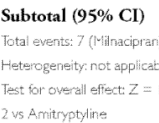 & $\begin{array}{l}{ }_{\text {ICAs) }} \\
\\
=0.133\end{array}$ & 55 & & $34.6 \%$ & $0.53[0.23,1.21]$ \\
\hline Annseau $1989 \mathrm{C}$ & $13 / 44$ & $16: 43$ & 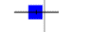 & $65.4 \%$ & $0.79[0.44,1,45]$ \\
\hline 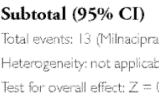 & 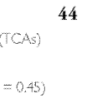 & 43 & & $65.4 \%$ & $0.79[0.44,1.45]$ \\
\hline $\begin{array}{l}\text { Total } \mathbf{( 9 5 \%} \mathbf{C I}) \\
\text { Total events: } 20 \text { (Milnacipra } \\
\text { Heterogeneity: Tau }{ }^{2}=00 \text {; } \\
\text { Test for overal ffect: } Z=\end{array}$ & $\begin{array}{l}\quad 96 \\
\text { (बCAs) } \\
0.62 \mathrm{df}=1(\mathrm{P} \\
=0.13)\end{array}$ & $\begin{array}{c}98 \\
x=0.0 \%\end{array}$ & & $100.0 \%$ & $0.69[0.42,1.12]$ \\
\hline & & & $\begin{array}{cccc}0.5 & 1 & 2 & 5 \\
\text { TCA. } & \text { Facours M }\end{array}$ & & \\
\hline
\end{tabular}


Analysis 25.1

Comparison 25 Subgroup analysis: Response at acute phase (6-12 weeks)-Flexible dosing, Outcome 1 Milnacipran vs TCAs

Review: Milnacipran versus other antidepressive agents for depression Comparison: 25 Subgroup analysis: Response at acute phase (6-12 weeks)-Flexible dosing Outcome: 1 Milnacipran vs TCAs

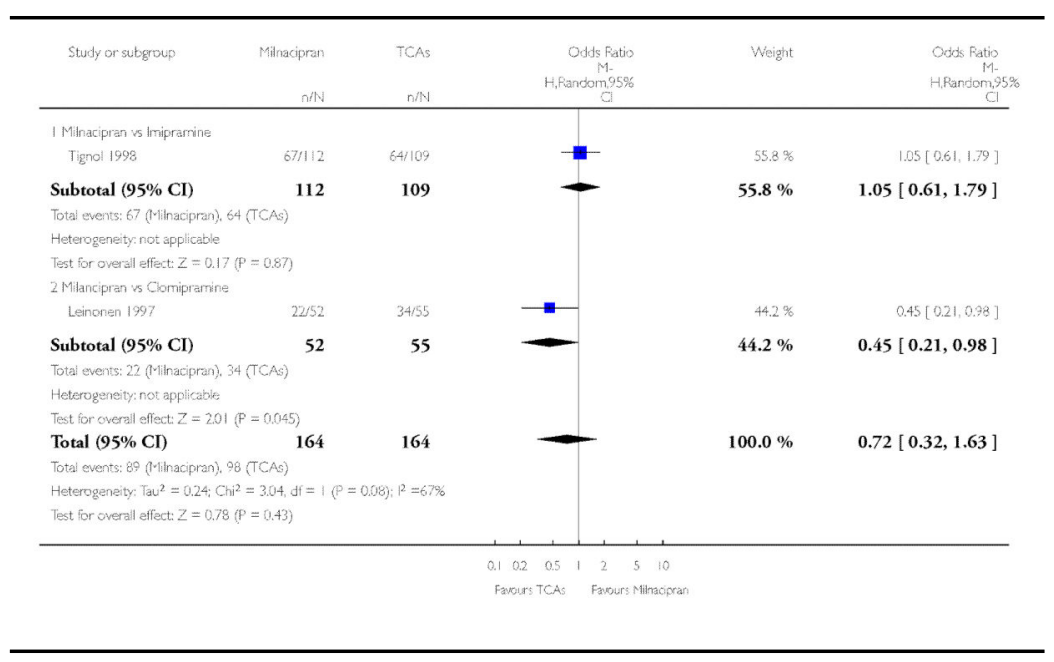


Analysis 26.1

Comparison 26 Subgroup analysis: Response at early phase (1-4 weeks)-Flexible dosing, Outcome 1 Milnacipran vs TCAs

Review: Milnacipran versus other antidepressive agents for depression

Comparison: 26 Subgroup analysis: Response at early phase (1-4 weeks)-Flexible dosing Outcome: 1 Milnacipran vs TCAs

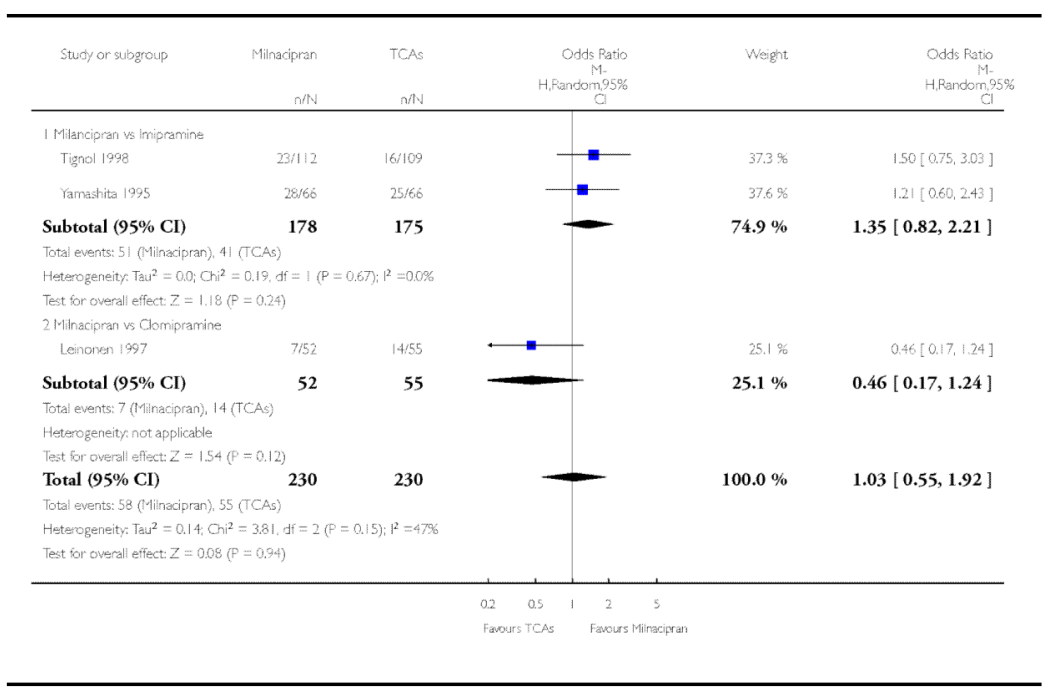




\section{Analysis 27.1}

Comparison 27 Subgroup analysis: Response at acute phase [6-12 weeks]-Outpatient, Outcome 1 Milnacipran vs SSRIs

Review: Milnacipran versus other antidepressive agents for depression Comparison: 27 Subgroup analysis: Response at acute phase [6-12 weeks]-Outpatient Outcome: 1 Milnacipran vs SSRIs

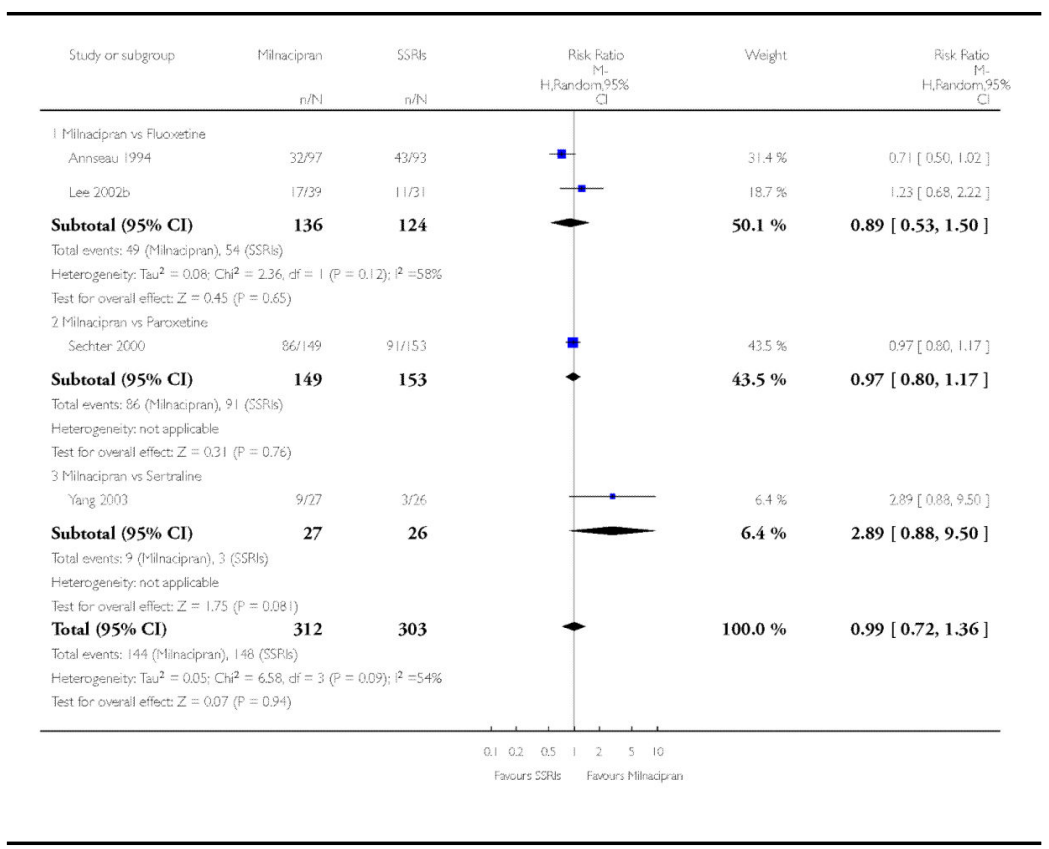




\section{Analysis 28.1}

Comparison 28 Subgroup analysis: Response at early phase [1-4 weeks]-Outpatient, Outcome 1 Milancipran vs SSRIs

Review: Milnacipran versus other antidepressive agents for depression Comparison: 28 Subgroup analysis: Response at early phase [1-4 weeks]-Outpatient Outcome: 1 Milancipran vs SSRIs

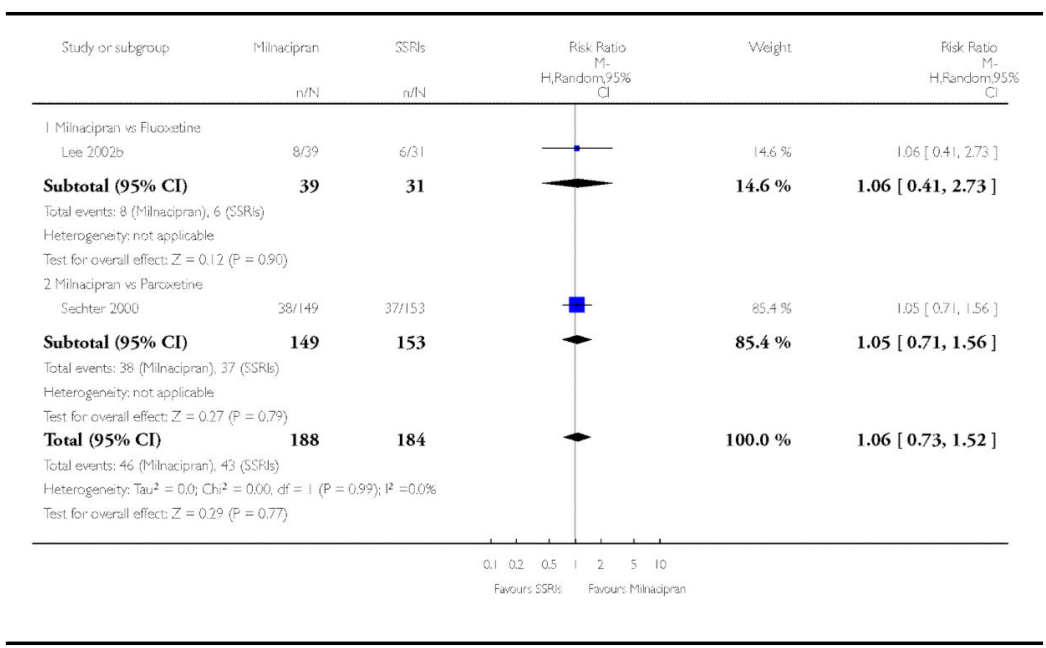




\section{Analysis 29.1}

Comparison 29 Subgroup analysis: Response at early phase [1-4 weeks]-Inpatient, Outcome 1 Milnacipran vs TCAs

Review: Milnacipran versus other antidepressive agents for depression Comparison: 29 Subgroup analysis: Response at early phase [1-4 weeks]-Inpatient Outcome: 1 Milnacipran vs TCAs

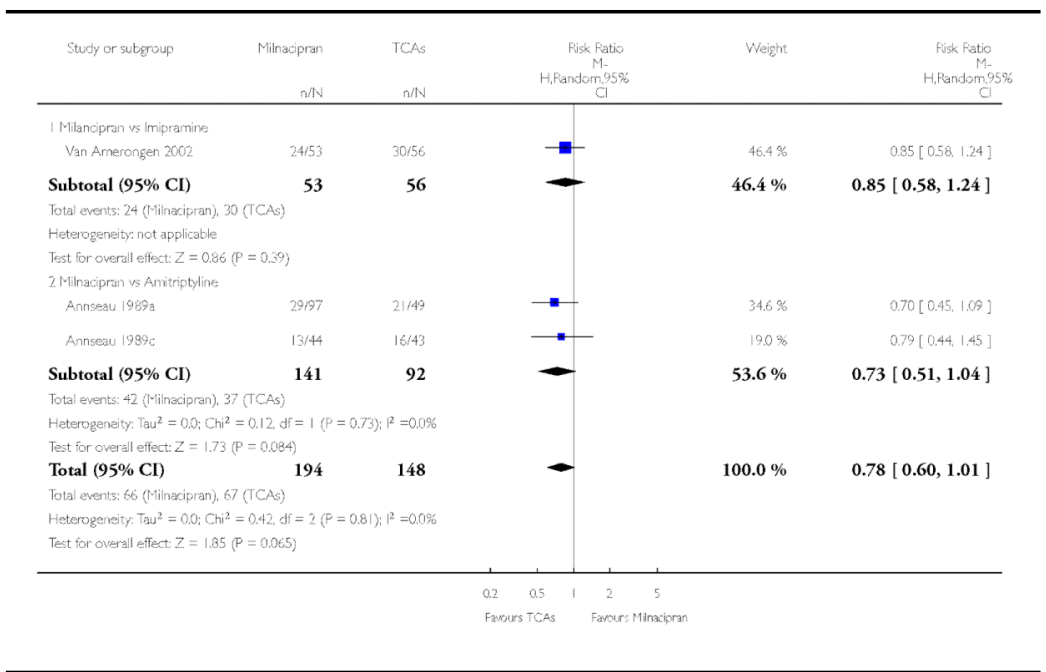




\section{Analysis 29.2}

Comparison 29 Subgroup analysis: Response at early phase [1-4 weeks]-Inpatient, Outcome 2 Milancipran vs SSRIs

Review: Milnacipran versus other antidepressive agents for depression Comparison: 29 Subgroup analysis: Response at early phase [1-4 weeks]-Inpatient Outcome: 2 Milancipran vs SSRIs

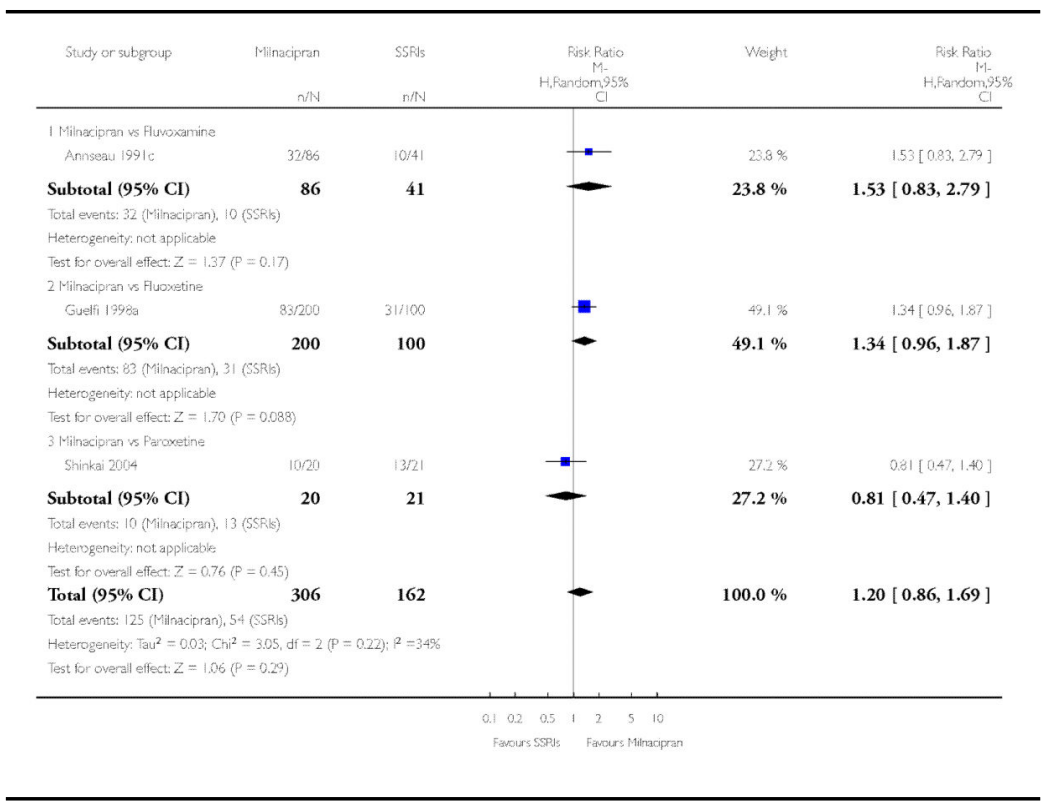

\section{Analysis 30.1}

Comparison 30 Subgroup analysis: Response at acute phase [6-12 weeks]-Inpatient, Outcome 1 Milnacipran vs TCAs

Review: Milnacipran versus other antidepressive agents for depression Comparison: 30 Subgroup analysis: Response at acute phase [6-12 weeks]-Inpatient Outcome: 1 Milnacipran vs TCAs

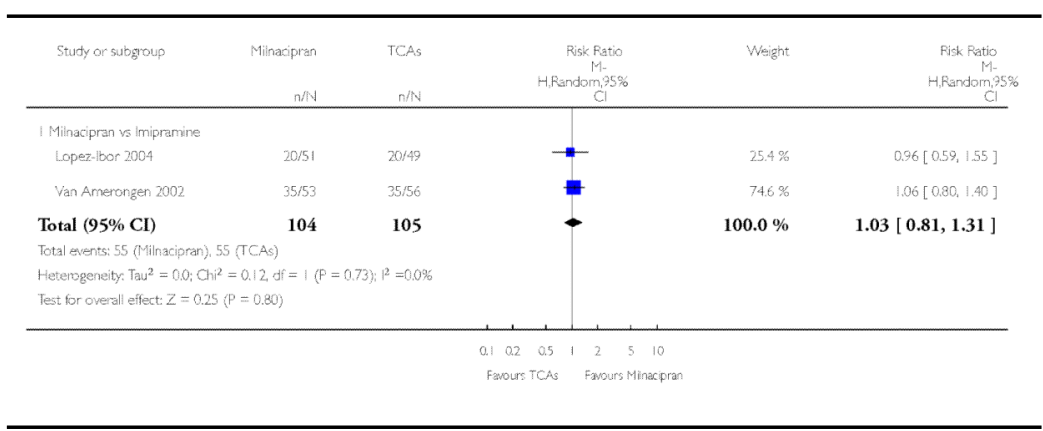




\section{HISTORY}

Protocol first published: Issue 2, 2007

Review first published: Issue 3, 2009

\begin{tabular}{lll}
\hline Date & Event & Description \\
\hline 20 April 2009 & Amended & $\begin{array}{l}\text { Changed title from 'Milnacipran versus types of pharmacotherapy for depression' } \\
\text { to 'Milnacipran versus other antidepressive agents for depression' }\end{array}$ \\
\hline 8 October 2008 & Amended & Converted to new review format. \\
\hline 20 September 2008 & Amended & Substantive amendment \\
\hline
\end{tabular}

\section{DIFFERENCES BETWEEN PROTOCOL AND REVIEW}

None.

\section{References to studies included in this review}

Annseau 1989a \{published data only\} . *Ansseau M, von Frenckell R, Mertens C, de Wilde J, Botte L, Devoitille JM, Evrard JL, De Nayer A, Darimont P, Dejaiffe G, Mirel J, Meurice E, Parent M, Couzinier JP, Demarez JP, Serre C. Controlled comparison of two doses of milnacipran (F 2207) and amitriptyline in major depressive inpatients. Psychopharmacology. 1989; 98(2):163-8. [PubMed: 2569214]

von Frenckell R, Ansseau M, Serre C, Sutet P. Pooling two controlled comparisons of milnacipran (F2207) and amitriptyline in endogenous inpatients. A new approach in dose ranging studies. International Clinical Psychopharmacology. 1990; 5:49-56. [PubMed: 2185303]

Annseau 1989c \{published data only\} . *Ansseau M, Von Frenckell R, Papart P, Mertens C, de Wilde J, Botte L, Devoitille JM, Evrard JL, De Nayer A, Koch-Bourdouxhe S, Darimont P, Lecoq A, Mirel J, Couzinier JP, Demarez JP, Serre C. Controlled comparison of milnacipran (F2207) $200 \mathrm{mg}$ and amitriptyline in endogenous depressive inpatients. Human Psychopharmacology. 1989; 4:221-7.

Ansseau M, Von Frenckell R, Serre C, Demarez JP. Controlled comparison of milnacipran (F2207) $200 \mathrm{mg}$ and amitriptyline in endogenous depressive inpatients. Therapie. 1990; 45(3):292.

Annseau 1991c \{published data only\} . Ansseau M, von Frenckell R, Gerard MA, Mertens C, de Wilde J, Botte L, Devoitille JM, Evrard JL, De Nayer A, Darimont P, Mirel J, Troisfontaines B, Toussaint C, Couzinier JP, Demarez JP, Serre C. Interest of a loading dose of milnacipran in endogenous depressive inpatients. Comparison with the standard regimen and with fluvoxamine. European Neuropsychopharmacology. 1991; 1(2):113-21. [PubMed: 1821700]

Annseau 1994 \{published data only\} . Ansseau M, Papart P, Troisfontaines B, Bartholome F, Bataille M, Charles G, Schittecatte M, Darimont P, Devoitille JM, de Wilde J, Dufrasne M, Gilson H, Evrard J-L, De Nayer A, Kremer P, Mertens C, Serre C. Controlled comparison of milnacipran and fluoxetine in major depression. Psychopharmacology. 1994; 114(1):131-7. [PubMed: 7846195]

Clerc 2001 \{published data only\} . Clerc G, Assicot M, Bouchard JM, Cottin M, Guibert M, Liegaut D, Engel P, May JP, Oules J, Pagot R, Patris MF, Ruimy P, Sombret A, Van Amerongen AP, Tournoux A. Antidepressant efficacy and tolerability of milnacipran, a dual serotonin and noradrenaline reuptake inhibitor: A comparison with fluvoxamine. International Clinical Psychopharmacology. 2001; 16(3):145-51. [PubMed: 11354236]

Endo 1995 \{published data only\} . Endo S, Miura S, Miyasaka M, Yamauchi T, Asai M, Ushijima S, Kamijima K, Hasegawa K, Ogura T. Clinical Evaluation of Milnacipran Hydrochloride, a New 
Antidepressant for Depression and Depressive State Phase III Clinical Trial with Mianserin Hydrochloride as a Control Drug. Rinsho Hyoka. 1995; 23(1):39-64.

Guelfi 1998a \{published data only\} . Guelfi JD, Ansseau M, Corruble E, Samuelian JC, Tonelli I, Tournoux A, Pletan Y. A double-blind comparison of the efficacy and safety of milnacipran and fluoxetine in depressed inpatients. International Clinical Psychopharmacology. 1998; 13(3):1218. [PubMed: 9690979]

Lee 2002b \{published data only\} . *Lee MS, Ham BJ, Kee BS, Kim JB, Yeon BK, Oh KS, Oh BH, Lee C, Jung HY, Chee IS, Choe BM, Paik IH. A comparison of the efficacy and safety between milnacipran and fluoxetine in the treatment of patients with depression. International Journal of Neuropsychopharmacology. 2002; 5(Suppl 1):205.

Lee MS, Ham BJ, Kee BS, Kim JB, Yeon BK, Oh KS, Oh BH, Lee C, Jung HY, Chee IS, Choe BM, Paik IH. Comparison of efficacy and safety of milnacipran and fluoxetine in Korean patients with major depression. Current Medical Research \& Opinion. 2005; 21(9):1369-75. [PubMed: 16197655]

Leinonen 1997 \{published data only . Leinonen E, Lepola U, Koponen H, Mehtonen OP, Rimon R. Long-term efficacy and safety of milnacipran compared to clomipramine inpatients with major depression. Acta Psychiatrica Scandinavica. 1997; 96(6):497-504. [PubMed: 9421348]

Lopez-Ibor 2004 \{published data only\} . Lopez-Ibor JJ, Conesa A. Spanish Milnacipran/ Imipramine Study. A comparative study of milnacipran and imipramine in the treatment of major depressive disorder. Current Medical Research and Opinion. 2004; 20(6):855-60. [PubMed: 15200743]

Sechter 2000 \{published data only\} . Sechter D, Vandel P, Weiller E, Pezous N, Cabanac F, Tournoux A. A comparative study of milnacipran and paroxetine in outpatients with major depression. Journal of Affective Disorders. 2004; 83(2-3):233-6. [PubMed: 15555719]

* Sechter D, Weiller E, Pezous N, Bisserbe JC. Psychomotor retardation is a predictive factor of milnacipran response. International Journal of Neuropsychopharmacology. 2000; 3(Suppl 1):190.

Vandel P, Sechter D, Weiller E, Pezous N, Cabanac F, Tournoux A, Panconi E. Post-treatment emergent adverse events in depressed patients following treatment with milnacipran and paroxetine. Human Psychopharmacology. 2004; 19(8):585-6. [PubMed: 15570574]

Shinkai 2004 \{published data only\} . Shinkai K, Yoshimura R, Ueda N, Okamoto K, Nakamura J. Associations between baseline plasma MHPG (3-methoxy-4-hydroxyphenylglycol) levels and clinical responses with respect to milnacipran versus paroxetine treatment. Journal of Clinical Psychopharmacology. 2004; 24(1):11-17. [PubMed: 14709941]

Tignol 1998 \{published data only\} . Tignol J, Pujol Domenech J, Chartres JP, Leger JM, Pletan Y, Tonelli I, Tournoux A, Pezous N. Double-blind study of the efficacy and safety of milnacipran and imipramine in elderly patients with major depressive episode. Acta Psychiatrica Scandinavica. 1998; 97(2):157-65. [PubMed: 9517912]

Van Amerongen 2002 \{published data only\} . Van Amerongen AP, Ferrey G, Tournoux A. A randomised, double-blind comparison of milnacipran and imipramine in the treatment of depression. Journal of Affective Disorders. 2002; 72(1):21-31. [PubMed: 12204314]

Yamashita 1995 \{published data only\} . Matsubara, R.; Onodera, I.; Ito, K.; Okada, F.; Asano, Y. A double-blind comparison of milnacipran and imipramine in depressive patients; XXth Collegium Internationale Neuro psychopharmacologicum; Melbourne, Australia. 1996;

*Yamashita I, Matubara R, Onodera I, Ito K, Okada K, Asano Y. Clinical evaluation of milnacipran hydrochloride (tn-912) on depression and depressive states -phase iii clinical trial with imipramine hydrochloride as a control drug. Rinsyoiyaku. 1995; 11(4):819-42.

Yang 2003 \{published data only\} . Yang JC, Kim SW, Yu BH. Milnacipran versus Sertraline in Major Depressive Disorder: A Double-Blind Randomized Comparative Study on the Treatment Effect and cbeta-Adrenergic Receptor Responsiveness. Korean Journal of Psychopharmacology. 2003; 14(4):387-96. 


\section{References to studies excluded from this review}

Baek 2002a \{published data only\} . Baek HK, Kim EJ, Yu BH. The Effect of Antidepressant Treatment on Beta-Adrenergic Receptor Responsiveness in Patients with Major Depression. Korean Journal of Psychopharmacology. 2002; 13(3):154-63.

Baek 2002b \{published data only\} . Baek HK, Yu BH. The effect of antidepressant treatment on beta-adrenergic receptor responsiveness in patients with major depression. International Journal of Neuropsychopharmacology. 2002; 5(Suppl 1):148.

Dardennes 1998 \{published data only\} . *Dardennes, R.; Berdeaux, G.; Bisserbe, JC.; Lafuma, A.; Pribil, C.; Fagnani, F. Cost-utility of milnacipran (Ixel(r)) in the prevention of recurrent depression; 11th European College of Neuropsychopharmacology Congress; Paris, France. 31st October 4th November 1998;

Dardennes RM, Lafuma A, Fagnani F, Pribil C, Bisserbe JC, Berdeaux G. Economic assessment of a maintenance treatment strategy in prevention of recurrent depressive disorder. Value in Health. 2000; 3(1):40-7. [PubMed: 16464180]

Lafuma A, Dardennes R, Fagnani F, Pribil C, Bisserbe JC, Berdeaux G. Clinico-economic assessment of milnacipran in the prevention of depressive episodes. Encephale. 1999; 25(5):401-7. [PubMed: 10598302]

Rouillon F, Berdeaux G, Bisserbe JC, Warner B, Mesbah M, Smadja C, Chwalow J. Prevention of recurrent depressive episodes with milnacipran: consequences on quality of life. Journal of Affective Disorders. 2000; 58(3):171-80. [PubMed: 10802126]

Rouillon, F.; Berdeaux, G.; Chwalow, J.; Mesbah, M. The efficacy of milnacipran (IxelR) in the prevention of recurrent depression: effects on quality of life; 11th European College of Neuropsychopharmacology Congress; Paris, France. 31st October 4th November 1998;

Rouillon F, Warner B, Pezous N, Bisserbe JC. Milnacipran efficacy in the prevention of recurrent depression: a 12-month placebo-controlled study. International Clinical Psychopharmacology. 2000; 15(3):133-40. [PubMed: 10870871]

Kanemoto 2004 \{published data only . Kanemoto K, Matsubara M, Yamashita K, Tarao Y, Inada E, Sekine T. Controlled comparison of two different doses of milnacipran in major depressive outpatients. International Clinical Psychopharmacology. 2004; 19(6):343-6. [PubMed: 15486520]

Lee 2004 \{published data only . Lee MS, Ham BJ, Kee BS, Kim JB, Yeon BK, Oh KS, Oh BH, Lee C, Jung HY, Chee IS, Choe BM, Paik IH. The Efficacy and Safety of Milnacipran in Patients with Major Depression: A comparison with Fluoxetine. Journal of the Korean Neuropsychiatric Association. 2004; 43(4):415-24.

Macher 1989 \{published data only\} . Macher JP, Sichel JP, Serre C, Von Frenckell R, Huck JC, Demarez JP. Double-blind placebo-controlled study of milnacipran in hospitalized patients with major depressive disorders. Neuropsychobiology. 1989; 22(2):77-82. [PubMed: 2701744]

Naito 2007 \{published data only\} . Shingo N, Kazuhiro S, Keizo Y, Hisashi H, Hitoshi T, Mitsuhiro K, Kenichi I, Tadashi O, Tetsuo S. Gender differences in the clinical effects of fluvoxamine and milnacipran in Japanese major depressive patients. Psychiatry and Clinical Neurosciences. 2007; 61(4):421-7. [PubMed: 17610668]

Onodera 1992 \{published data only\} . Onodera I, Asano Y, Ito K, Matsubara R, Okada F. Doubleblind controlled comparison of two doses of milnacipran in depressive patients. Clinical Neuropharmacology. 1992; 15(1 Pt B):418.

Wyeth 2006 \{published data only\} . Wyeth. Phase III multi-center, double-blind, comparative study of Effexor XR for the treatment of depression. 2006controlled-trials.com

\section{References to studies awaiting assessment}

Yoshimura 2007 \{published data only\} . Yoshimura R, Mitoma M, Sugita A, Hori H, Okamoto T, Umene W, Ueda N, Nakamura J. Effects of paroxetine or milnacipran on serum brain-derived neurotrophic factor in depressed patients. Progress in Neuropsychopharmacology and Biological Psychiatry. 2007; 31:1034-7. 


\section{Additional references}

Als-Nielsen 2003 . Als-Nielsen B, Chen W, Gluud C, Kjaergard LL. Association of funding and conclusions in randomized drug trials: a reflection of treatment effect or adverse events? JAMA. Aug 20; 2003 290(7):921-8. [PubMed: 12928469]

Altman 1996 . Altman DG, Bland JM. Detecting skewness from summary information. BMJ. Nov 9.1996 313(7066):1200. [PubMed: 8916759]

Anderson 2000a . Anderson IM, Nutt DJ, Deakin JF. Evidence-based guidelines for treating depressive disorders with antidepressants: a revision of the 1993 British Association for Psychopharmacology guidelines. British Association for Psychopharmacology. Journal of Psychopharmacology. Mar; 2000 14(1):3-20. [PubMed: 10757248]

APA 1980 . American Psychiatric Association. Diagnostic and Statistical Manual of Mental Disorders (DSM-III). 3rd Edition. American Psychiatric Association; Washington, DC: 1980.

APA 1987 . American Psychiatric Association. Diagnostic and Statistical Manual of Mental Disorders (DSM-III-R). 3rd Edition. American Psychiatric Association; 1987.

APA 1994 . American Psychiatric Association. Diagnostic and Statistical Manual of Mental Disorders (DSM-IV). 4th Edition. American Psychiatric Association; Washington, DC: 1994.

APA 2000 . American Psychiatric Association. Practice guideline for the treatment of patients with major depressive disorder (revision). American Psychiatric Association. American Journal of Psychiatry. Apr; 2000 157(4 Suppl):1-45.

Appleton 2006 . Appleton KM, Hayward RC, Gunnell D, Peters TJ, Rogers PJ, Kessler D, Ness AR. Effects of n-3 long-chain polyunsaturated fatty acids on depressed mood: systematic review of published trials. American Journal of Clinical Nutrition. 2006; 84(6):1308-16. [PubMed: 17158410]

Arroll 2005 . Arroll B, Macgillivray S, Ogston S, Reid I, Sullivan F, Williams B, et al. Efficacy and tolerability of tricyclic antidepressants and SSRIs compared with placebo for treatment of depression in primary care: a meta-analysis. Annals of Family Medicine. Sep-Oct;2005 3(5): 449-56. [PubMed: 16189062]

Barbui 2004 . Barbui C, Cipriani A, Brambilla P, Hotopf M. "Wish bias" in antidepressant drug trials? Journal of Clinical Psychopharmacology. Apr; 2004 24(2):126-30. [PubMed: 15206658]

Barbui 2007 . Barbui C, Hotopf M, Freemantle N, Boynton J, Churchill R, Eccles MP, Geddes JR, Hardy R, Lewis G, Mason JM. Selective serotonin reuptake inhibitors versus tricyclic and heterocyclic antidepressants: comparison of drug adherence. Cochrane Database of Systematic Reviews. 2007; (3) DOI: CD002791.

Bekelman 2003 . Bekelman JE, Li Y, Gross CP. Scope and impact of financial conflicts of interest in biomedical research: a systematic review. JAMA. 2003; 289(4):454-65. [PubMed: 12533125]

Bhandari 2004 . Bhandari M, Busse JW, Jackowski D, Montori VM, Schunemann H, Sprague S, Mears D, Schemitsch EH, Heels-Ansdell D, Devereaux PJ. Association between industry funding and statistically significant pro-industry findings in medical and surgical randomised trials. Canadian Medical Association Journal. Feb 17; 2004 170(4):477-80. [PubMed: 14970094]

Bollini 1999 . Bollini P, Pampallona S, Tibaldi G, Kupelnick B, Munizza C. Effectiveness of antidepressants. Meta-analysis of dose-effect relationships in randomised clinical trials. British Journal of Psychiatry. Apr.1999 174:297-303. [PubMed: 10533547]

Briley 1996 . Briley M, Prost J, Moret C. Preclinical pharmacology of milnacipran. International Clinical Psychopharmacology. 1996; 11(Suppl. 4):9-14. [PubMed: 8923122]

Buchkowsky 2004 . Buchkowsky SS, Jewesson PJ. Industry sponsorship and authorship of clinical trials over 20 years. Annals of Pharmacotherapy. Apr; 2004 38(4):579-85. [PubMed: 14982982]

Chan 2004 . Chan AW, Hrobjartsson A, Haahr MT, Gotzsche PC, Altman DG. Empirical evidence for selective reporting of outcomes in randomized trials: comparison of protocols to published articles. JAMA. 2004; 291(20):2457-65. [PubMed: 15161896]

Chan 2005 . Chan AW, Altman DG. Identifying outcome reporting bias in randomised trials on PubMed: review of publications and survey of authors. BMJ. 7494:753. 330. 
Cipriani 2005 . Cipriani A, Brambilla P, Furukawa T, Geddes J, Gregis M, Hotopf M, Malvini L, Barbui C. Fluoxetine versus other types of pharmacotherapy for depression. Cochrane Database of Systematic Reviews. Oct 19.2005 (4) DOI: CD004185.

Cipriani 2007a . Cipriani A, Furukawa TA, Veronese A, Watanabe N, Churchill R, McGuire HF, Barbui C, Meta-Analysis of New Generation Antidepressants (MANGA) Study Group. Paroxetine versus other anti-depressive agents for depression. Cochrane Database of Systematic Reviews. 2007; (2)

Cipriani 2007b . Cipriani A, Signoretti A, Furukawa TA, Churchill R, Tomelleri S, Omori IM, McGuire HF, Barbui C, Meta-Analysis of New Generation Antidepressants (MANGA) Study Group. Venlafaxine versus other anti-depressive agents for depression. Cochrane Database of Systematic Reviews. 2007; (2)

Cipriani 2009a . Cipriani A, Furukawa TA, Salanti G, Geddes JR, Higgins JP, Churchill R, Watanabe N, Nakagawa A, Omori IM, McGuire H, Tansella M, Barbui C. Comparative efficacy and acceptability of 12 new-generation antidepressants: a multiple-treatments meta-analysis. Lancet. 2009; 373(9665):746-58. [PubMed: 19185342]

Cipriani 2009b . Cipriani A, La Ferla T, Furukawa TA, Signoretti A, Nakagawa A, Churchill R, McGuire H, Barbui C. Sertraline versus other antidepressive agents for depression. Cochrane Database of Systematic Reviews. 2009; (2):CD006117. Art. No.: CD006117. DOI: 10.1002/14651858.CD006117.pub3. [PubMed: 19370626]

Cipriani 2009c . Cipriani A, Santilli C, Furukawa TA, Signoretti A, Nakagawa A, McGuire H, Churchill R, Barbui C. Escitalopram versus other antidepressive agents for depression. Cochrane Database of Systematic Reviews. 2009; (2):CD006532. Art. No.: CD006532. DOI: 10.1002/14651858.CD006532.pub2. [PubMed: 19370639]

Ciuna 2004 . Ciuna A, Andretta M, Corbari L, Levi D, Mirandola M, Sorio A, et al. Are we going to increase the use of antidepressants up to that of benzodiazepines? European Journal of Clinical Pharmacology. Nov; 2004 60(9):629-34. [PubMed: 15448956]

Cowen 2005 . Cowen PJ, Ogilvie AD, Gama J. Efficacy, safety and tolerability of duloxetine $60 \mathrm{mg}$ once daily in major depression. Current Medical Research and Opinion. 2005; 21(3):345-56. [PubMed: 15811202]

Coyne 1994 . Coyne JC, Fechner-Bates S, Schwenk TL. Prevalence, nature, and comorbidity of depressive disorders in primary care. General Hospital Psychiatry. Jul; 1994 16(4):267-76. [PubMed: 7926703]

Elliott 2007 . Elliott WJ, Meyer PM. Incident diabetes in clinical trials of antihypertensive drugs: a network meta-analysis. Lancet. 2007; 369(9557):201-7. [PubMed: 17240286]

Ellis 2004 . Ellis P. Australian and New Zealand clinical practice guidelines for the treatment of depression. Australian and New Zealand Journal of Psychiatry. Jun; 2004 38(6):389-407. [PubMed: 15209830]

Frampton 2007 . Frampton JE, Plosker GL. Duloxetine: a review of its use in the treatment of major depressive disorder. CNS Drugs. 2007; 21(7):581-609. [PubMed: 17579500]

Furukawa 2002a . Furukawa TA, Guyatt GH, Griffith LE. Can we individualize the 'number needed to treat'? An empirical study of summary effect measures in meta-analyses. International Journal of Epidemiology. Feb; 2002 31(1):72-6. [PubMed: 11914297]

Furukawa 2002b . Furukawa TA, McGuire H, Barbui C. Meta-analysis of effects and side effects of low dosage tricyclic antidepressants in depression: systematic review. BMJ. Nov 2; 2002 325(7371):991-5. [PubMed: 12411354]

Furukawa 2005 . Furukawa TA, Cipriani A, Barbui C, Brambilla P, Watanabe N. Imputing response rates from means and standard deviations in meta-analysis. International Clinical Psychopharmacology. 2005; 20(1):49-52. [PubMed: 15602117]

Furukawa 2006 . Furukawa TA, Barbui C, Cipriani A, Brambilla P, Watanabe N. Imputing missing standard deviations in meta-analyses can provide accurate results. Journal of Clinical Epidemiology. Jan; 2006 59(1):7-10. [PubMed: 16360555]

Geddes 2000 . Geddes JR, Freemantle N, Mason J, Eccles MP, Boynton J. SSRIs versus other antidepressants for depressive disorder. Cochrane Database of Systematic Reviews. 2000; (2) DOI: CD001851. 
Goldstein 2002 . Goldstein DJ, Mallinckrodt C, Lu Y, Demitrack MA. Duloxetine in the treatment of major depressive disorder: a double-blind clinical trial. Journal of Clinical Psychiatry. 2002; 63(6):225-31. [PubMed: 11926722]

Greenberg 2003 . Greenberg PE, Kessler RC, Birnbaum HG, Leong SA, Lowe SW, Berglund PA, Corey-Lisle PK. The economic burden of depression in the United States: how did it change between 1990 and 2000? Journal of Clinical Psychiatry. Dec; 2003 64(12):1465-75. [PubMed: 14728109]

Greenberg 2005 . Greenberg PE, Birnbaum HG. The economic burden of depression in the US: societal and patient perspectives. Expert Opinion on Pharmacotherapy. Mar; 2005 6(3):369-76. [PubMed: 15794728]

Guaiana 2005 . Guaiana G, Andretta M, Corbari L, Mirandola M, Sorio A, D’Avanzo B, Barbui C. Antidepressant drug consumption and public health indicators in Italy, 1955 to 2000. Journal of Clinical Psychiatry. Jun; 2005 66(6):750-5. [PubMed: 15960569]

Guaiana 2007 . Guaiana G, Barbui C, Hotopf M. Amitriptyline versus other types of pharmacotherapy for depression. Cochrane Database of Systematic Reviews. 2007; (3) DOI: CD004186.

Guelfi 1998 . Guelfi JD, Ansseau M, Corruble E, Samuelian JC, Tonelli I, Tournoux A, Pletan Y. A double-blind comparison of the efficacy and safety of milnacipran and fluoxetine in depressed inpatients. International Clinical Psychopharmacology. May; 1998 13(3):121-8. [PubMed: 9690979]

Guy 1970 . Guy W, Bonato RR.

Hamilton 1960 . Hamilton M. A rating scale for depression. Journal of Neurology, Neurosurgery and Psychiatry. 1960; 23:56-62.

Hansen 2005 . Hansen RA, Gartlehner G, Lohr KN, Gaynes BN, Carey TS. Efficacy and safety of second-generation antidepressants in the treatment of major depressive disorder. Annals of Internal Medicine. Sep 20; 2005 143(6):415-26. [PubMed: 16172440]

Heres 2006 . Heres S, Davis J, Maino K, Jetzinger E, Kissling W, Leucht S. Why olanzapine beats risperidone, risperidone beats quetiapine, and quetiapine beats olanzapine: an exploratory analysis of head-to-head comparison studies of second-generation antipsychotics. American Journal of Psychiatry. 2006; 163(2):185-94. [PubMed: 16449469]

Higgins 2003 . Higgins JP, Thompson SG, Deeks JJ, Altman DG. Measuring inconsistency in metaanalyses. BMJ. Sep 6; 2003 327(7414):557-60. [PubMed: 12958120]

Higgins 2005 . Higgins, JP.; Green, S., editors. Cochrane Handbook for Systematic Reviews of Interventions 4.2.5. John Wiley \& Sons, Ltd.; Chichester, UK: May. 2005

Higgins 2008a . Higgins, JPT.; Altman, DG.; Green, S. Cochrane Handbook for Systematic Reviews of Interventions version 5.01 (updated Sept 2008). Higgins, JPT., editor. The Cochrane Collaboration; 2008.

Higgins 2008b . Higgins, JPT.; Altman, DG. Section 8. Assessing risk of bias in included studies. In: Higgins, JPT.; Green, S., editors. Cochrane Handbook for Systematic Reviews of Interventions version 5.01 (updated Sept 2008). The Cochrane Collaboration; 2008.

Imperadore 2007 . Imperadore G, Cipriani A, Signoretti A, Furukawa TA, Watanabe N, Churchill R, McGuire HF, Barbui C, Meta-Analysis of New Generation Antidepressants (MANGA) Study Group. Citalopram versus other anti-depressive agents for depression. Cochrane Database of Systematic Reviews. 2007; (2)

Ioannidis 2006 . Ioannidis JP. Indirect comparisons: the mesh and mess of clinical trials. Lancet. 2006; 368(9546):1470-2. [PubMed: 17071265]

Ito 2002 . Ito K, Yoshida K, Sato K, Takahashi H, Kamata M, Higuchi H, Shimizu T, Itoh K, Inoue K, Tezuka T, Suzuki T, Ohkubo T, Sugawara K, Otani K. A variable number of tandem repeats in the serotonin transporter gene does not affect the antidepressant response to fluvoxamine. Psychiatry Research. 2002; 111(2-3):235-9. [PubMed: 12374640]

Kessler 2003 . Kessler RC, Berglund P, Demler O, Jin R, Koretz D, Merikangas KR, Rush AJ, Walters EE, Wang PS. National Comorbidity Survey Replication. JAMA. Jun 18; 2003 289(23): 3095-105. [PubMed: 12813115] 
Khan 2003 . Khan A, Khan SR, Walens G, Kolts R, Giller EL. Frequency of positive studies among fixed and flexible dose antidepressant clinical trials: an analysis of the food and drug administration summary basis of approval reports. Neuropsychopharmacology. Mar; 2003 28(3): 552-7. [PubMed: 12629536]

Kupfer 2002 . Kupfer DJ, Frank E. Placebo in clinical trials for depression: complexity and necessity. JAMA. 2002; 287:1853-54. [PubMed: 11939872]

Lecrubier 1996 . Lecrubier Y, Pletan Y, Solles A, Tournoux A, Magne V. Clinical efficacy of milnacipran: placebo-controlled trials. International Clinical Psychopharmacology. Sep; 1996 11(Suppl 4):29-33. [PubMed: 8923124]

Lexchin 2003 . Lexchin J, Bero LA, Djulbegovic B, Clark O. Pharmaceutical industry sponsorship and research outcome and quality: systematic review. BMJ. May 31; 2003 326(7400):1167-70. [PubMed: 12775614]

Linde 2008 . Linde K, Berner MM, Kriston L. St John's wort for major depression. Cochrane Database of Systematic Reviews. 2008; (4) Art. No.:CD000448.DOI: 10.1002/14651858.CD000448.pub3.

Lopez-Ibor 1996 . Lopez-Ibor J, Guelfi JD, Pletan Y, Tournoux A, Prost JF. Milnacipran and selective serotonin reuptake inhibitors in major depression. International Clinical Psychopharmacology. Sep; 1996 11(Suppl 4):41-6. [PubMed: 8923126]

Lu 2004 . Lu M, Ades T. Combination of direct and indirect evidence in mixed treatment comparison. Statistics in Medicine. 2004; 23:3105-24. [PubMed: 15449338]

Lu 2006 . Lu M, Ades T. Assessing evidence consistency in mixed treatment comparisons. Journal of the American Statistical Association. 2006; 101:447-59.

Luborsky 1962 . Luborsky L. Clinician's judgments of mental health. Archives of General Psychiatry. 1962; 7:407-17. [PubMed: 13931376]

Lumley 2002 . Lumley S. Network meta-analysis for indirect treatment comparisons. Statistics in Medicine. 2002; 21:2313, 2324. [PubMed: 12210616]

Montgomery 1979 . Montgomery SA, Asberg M. A new depression scale designed to be sensitive to change. British Journal of Psychiatry. 1979; 134:382-9. [PubMed: 444788]

Montgomery 2004 . Montgomery JH, Byerly M, Carmody T, Li B, Miller DR, Varghese F, Holland R. An analysis of the effect of funding source in randomized clinical trials of second generation antipsychotics for the treatment of schizophrenia. Controlled Clinical Trials. Dec; 2004 25(6): 598-612. [PubMed: 15588746]

Moret 1985 . Moret C, Charveron M, Finberg JPM, Couzinier JP, Briley M. Biochemical profile of milnacipran (F 2207), 1-phenyl-1-diethyl-aminocarbonyl-2-aminomethyl-cyclopropane (Z) hydrochloride, a potential fourth generation antidepressant drug. Neuropharmacology. 1985; 24:1211-19. [PubMed: 3005901]

NICE 2007 . NICE. Depression: management of depression in primary and secondary care (amended). National Institute for Health and Clinical Excellence; London: 2007.

Nose 2007 . Nose M, Cipriani A, Furukawa TA, Omori IM, Churchill R, McGuire HF, Barbui C, Meta-Analysis of New Generation Antidepressants (MANGA) Study Group. Duloxetine versus other anti-depressive agents for depression. Cochrane Database of Systematic Reviews. 2007; (2)

Okamura 2006 . Okamura K, Furukawa TA. Remission rates with milnacipran 100mg/day and 150 $\mathrm{mg} /$ day in the long-term treatment of major depression. Clinical Drug Investigation. 2006; 26(3): 135-42. [PubMed: 17163244]

Omori 2006 . Omori IM, Watanabe N, Cipriani A, Barbui C, McGuire H, Churchill R, Furukawa TA for the MANGA Study. Fluvoxamine versus other anti-depressive agents for depression. (Protocol). Cochrane Database of Systematic Reviews. 2006; (3) CD006114.

Oxman 1992 . Oxman AD, Guyatt GH. A consumer's guide to subgroup analyses. Annals of Internal Medicine. Jan 1; 1992 116(1):78-84. [PubMed: 1530753]

Papakostas 2007a . Papakostas GI, Fava M. A meta-analysis of clinical trials comparing milnacipran, a serotonin-norepinephrine reuptake inhibitor, with a selective serotonin reuptake inhibitor for the treatment of major depressive disorder. European Neuropsychopharmacology. 2007; 17(1): 32-6. [PubMed: 16762534] 
Perlis 2005 . Perlis RH, Perlis CS, Wu Y, Hwang C, Joseph M, Nierenberg AA. Industry sponsorship and financial conflict of interest in the reporting of clinical trials in psychiatry. American Journal of Psychiatry. Oct; 2005 162(10):1957-60. [PubMed: 16199844]

Procyshyn 2004 . Procyshyn RM, Chau A, Fortin P, Jenkins W. Prevalence and outcomes of pharmaceutical industry-sponsored clinical trials involving clozapine, risperidone, or olanzapine. Canadian Journal of Psychiatry. Sep; 2004 49(9):601-6.

Psaty 2003 . Psaty BM, Lumley T, Furberg CD, Schellenbaum G, Pahor M, Alderman MH, Weiss NS. Health outcomes associated with various antihypertensive therapies used as first-line agents: a network meta-analysis. JAMA. 2003; 289(19):2533-44.

Puech 1997 . Puech A, Montgomery SA, Prost JF, Solles A, Briley M. Milnacipran, a new serotonin and noradrenaline reuptake inhibitor: an overview of its antidepressant activity and clinical tolerability. International Clinical Psychopharmacology. Mar; 1997 12(2):99-108. [PubMed: 9219045]

Puozzo 1996 . Puozzo C, Leonard BE. Pharmacokinetics of milnacipran in comparison with other antidepressants. International Clinical Psychopharmacology. Sep; 1996 11(Suppl 4):15-27. [PubMed: 8923123]

Puozzo 2005 . Puozzo C, Lens S, Reh C, Michaelis K, Rosillon D, Deroubaix X, Deprez D. Lack of interaction of milnacipran with the cytochrome P450 isoenzymes frequently involved in antidepressant metabolism. Clinical Pharmacokinetics. 2005; 44:977-8. [PubMed: 16122284]

Salanti 2008 . Salanti G, Higgins JP, Ades A, Ioannidis JP. Evaluation of networks of randomized trials. Statistical Methods in Medical Research. 2008; 17:279-301. [PubMed: 17925316]

Santaguida 2005 . Santaguida PL, Helfand M, Raina P. Challenges in systematic reviews that evaluate drug efficacy or effectiveness. Annals of Internal Medicine. 2005; 142(12 Pt 2):106672. [PubMed: 15968031]

Sawada 2001 . Sawada Y, Ohtani H. Pharmacokinetics and drug interactions of antidepressive agents. Nippon Rinsho. 2001; 59:1539-1545. [PubMed: 11519155]

Sechter 2004 . Sechter D, Vandel P, Weiller E, Pezous N, Cabanac F, Tournoux A. study cocoordinators. A comparative study of milnacipran and paroxetine in outpatients with major depression. Journal of Affective Disorders. Dec; 2004 83(2-3):233-6. [PubMed: 15555719]

Smith 2002 . Smith D, Dempster C, Glanville J, Freemantle N, Anderson I. Efficacy and tolerability of venlafaxine compared with selective serotonin reuptake inhibitors and other antidepressants: a meta-analysis. British Journal of Psychiatry. May.2002 180:396-404. [PubMed: 11983635]

Spencer 1998 . Spencer CM, Wilde MI. Milnacipran. A review of its use in depression. Drugs. Sep; 1998 56(3):405-27. [PubMed: 9777315]

Steen 1997 . Steen A, Den Boer JA. A double-blind six months comparative study of milnacipran and clomipramine in major depressive disorder. International Clinical Psychopharmacology. Sep; 1997 12(5):269-81. [PubMed: 9466161]

Thase 2001 . Thase ME, Entsuah AR, Rudolph RL. Remission rates during treatment with venlafaxine or selective serotonin reuptake inhibitors. British Journal of Psychiatry. 2001; 178:234-41. [PubMed: 11230034]

Walsh 2002 . Walsh BT, Seidman SN, Sysko R, Gould M. Placebo response in studies of major depression: variable, substantial, and growing. JAMA. Apr 10; 2002 287(14):1840-7. [PubMed: 11939870]

Ware 1993 . Ware, JE.; Snow, KK.; Kosinski, M.; Gandek, B. SF-36 Health Survey Manual and Interpretation Guide. New England Medical Centre; Boston, MA: 1993.

Watanabe 2006 . Watanabe N, Barbui C, Churchill R, Cipriani A, Furukawa TA, McGuire HF, Omori IM, MANGA Study. Mirtazapine versus other anti-depressive agents for depression (Protocol). Cochrane Database of Systematic Reviews. 2006; (3):CD006528.

WHO 1978 . World Health Organization. The Ninth Revision of the International Classification of Disease and Related Health Problems (ICD-9). World Health Organization; 1978.

WHO 1992 . World Health Organization. The Tenth Revision of the International Classification of Disease and Related Health Problems (ICD-10). World Health Organization; 1992.

WHO 2004 . World Health Organization. The Global Burden of Disease 2004 Update. World Health Organization; Geneva: 2004. 
WHOQOL Group 1998 . WHOQOL Group. The World Health Organization quality of life assessment (WHOQOL): Development and general psychometric properties. Social Science and Medicine. 1998; 46(12):1569-65. [PubMed: 9672396]

Williams 2000 . Williams JW Jr, Mulrow CD, Chiquette E, Noel PH, Aguilar C, Cornell J. A systematic review of newer pharmacotherapies for depression in adults: evidence report summary. Annals of Internal Medicine. May 2; 2000 132(9):743-56. [PubMed: 10787370]

Williams 2001 . Williams JB. Standardizing the Hamilton Depression Rating Scale: past, present, and future. European Archives of Psychiatry and Clinical Neuroscience. 2001; 251(Suppl 2):II16-12.

Wing 1994 . Wing, J. Measuring mental health outcomes: a perspective from the Royal College of Psychiatrists. Outcomes into Clinical Practice. BMJ Publishing; London, London: 1994.

Yoshida 2002 . Yoshida K, Ito K, Sato K, Takahashi H, Kamata M, Higuchi H, Shimizu T, Itoh K, Inoue K, Tezuka T, Suzuki T, Ohkubo T, Sugawara K, Otani K. Influence of the serotonin transporter gene-linked polymorphic region on the antidepressant response to fluvoxamine in Japanese depressed patients. Progress in Neuro-Psychopharmacology and Biological Psychiatry. 2002; 26(2):383-6. [PubMed: 11817517]

Zimmerman 2004 . Zimmerman M, Posternak MA, Chelminski I. Derivation of a definition of remission on Montgomery-Asberg depression rating scale corresponding to the definition of remission on the Hamilton rating scale for depression. Journal of Psychiatric Research. 2004; 38:577, 82. [PubMed: 15458853]

* Indicates the major publication for the study 


\section{PLAIN LANGUAGE SUMMARY}

\section{Milnacipran versus other antidepressive agents for depression}

Major depression, also known as major depressive disorder or unipolar depression, is a common mental disorder characterised by a combination of symptoms that interfere with a person's ability to work, sleep, study, eat, and enjoy pleasurable activities. An episode of major depression may occur only once in a person's lifetime, but more often, it recurs throughout a person's life.

Antidepressant drugs are frequently used as first-line treatment for major depression in primary and secondary care settings. Milnacipran, a dual serotonin-norepinephrine reuptake inhibitor, is one of the antidepressant drugs that clinicians use for routine depression care. This systematic review investigated the efficacy, acceptability and tolerability of milnacipran compared to that of other antidepressive agents in the acute phase treatment of major depression. A total of 16 randomised controlled trials (2277 participants) were included in this review. When we brought together the results of approximately 2000 patients, we were unable to say whether milnacipran is better, worse or the same when compared to other antidepressive agents used in practice in terms of efficacy, acceptability and tolerability. However, there is some evidence that fewer people taking milnacipran stop taking the drug ('drop out') due to side effects and fewer people taking milnacipran experience side effects such as sleepiness, dry mouth or constipation than do people who take tricyclic antidepressants. 


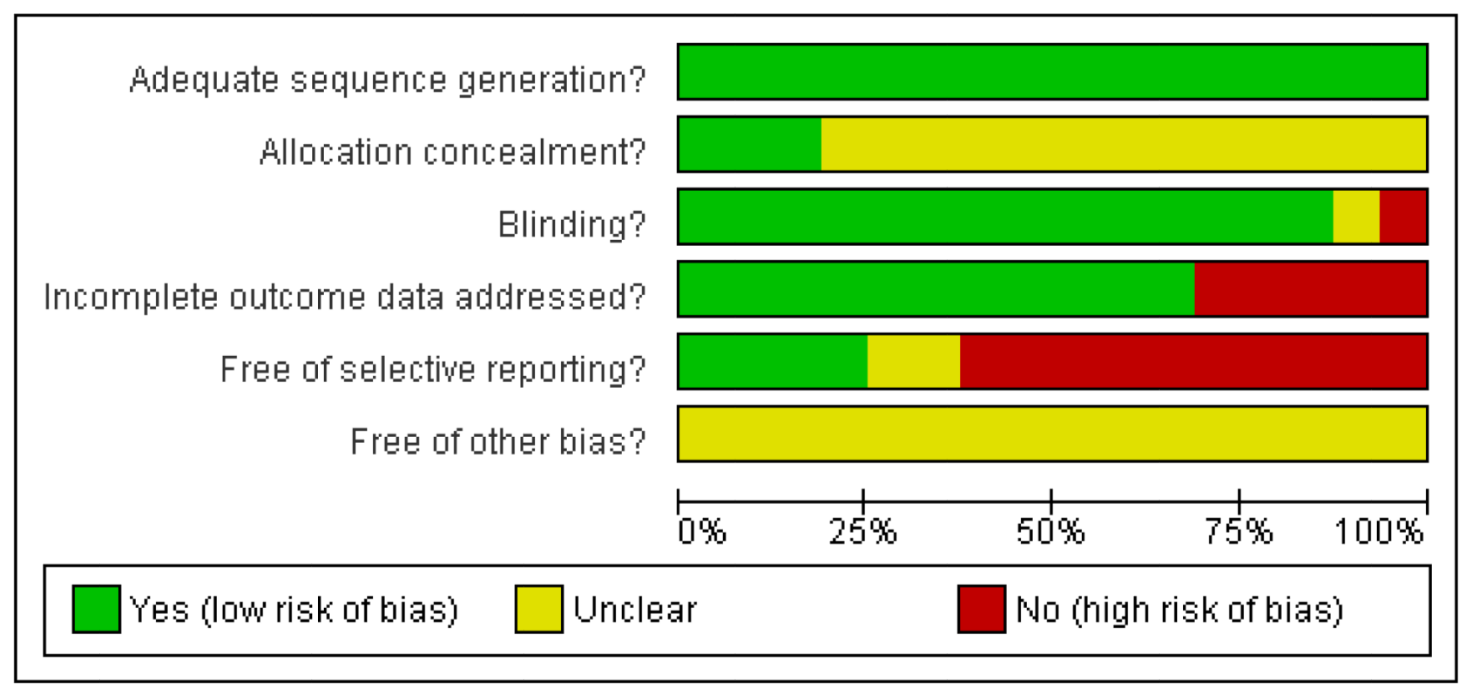

Figure 1. Methodological quality graph: review authors' judgements about each methodological quality item presented as percentages across all included studies 


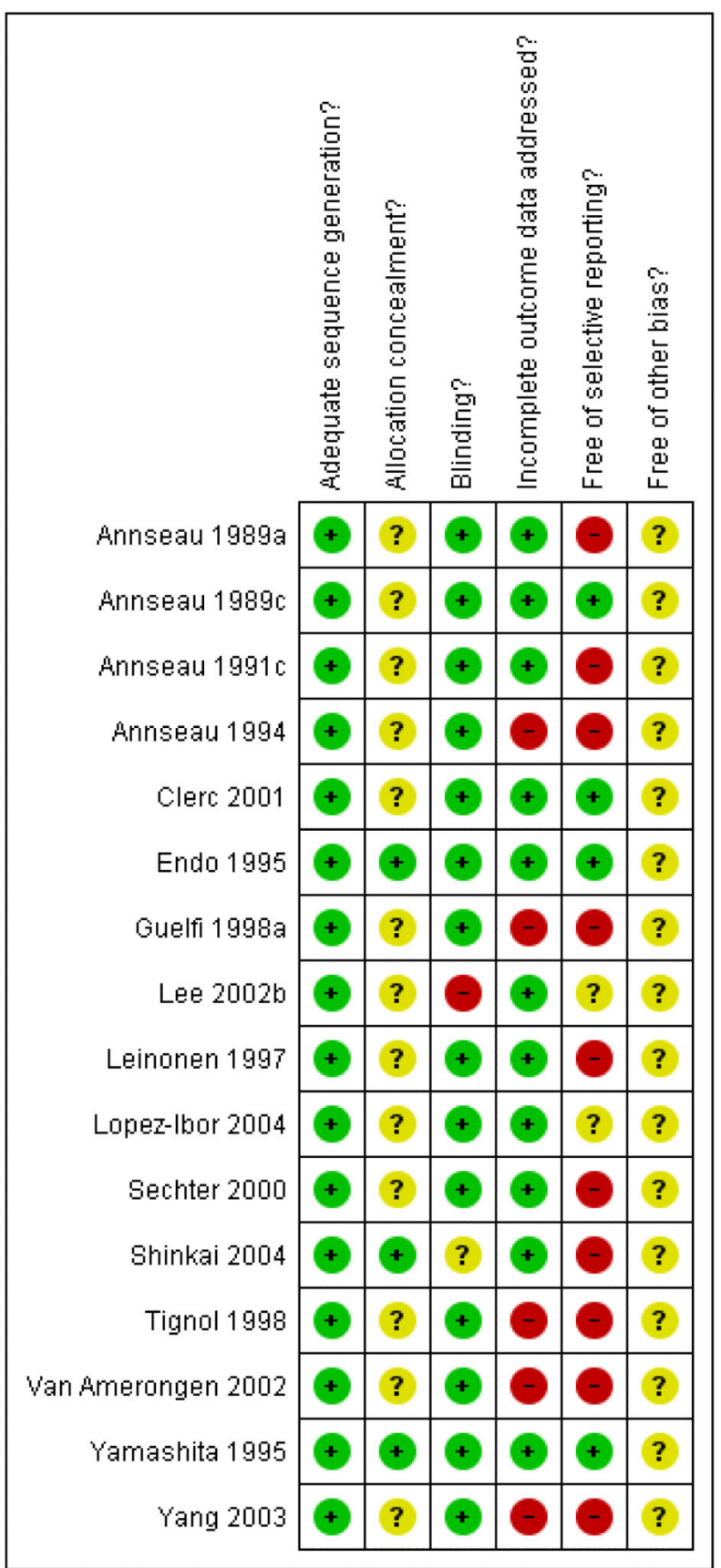

Figure 2. Methodological quality summary: review authors' judgements about each methodological quality item for each included study 


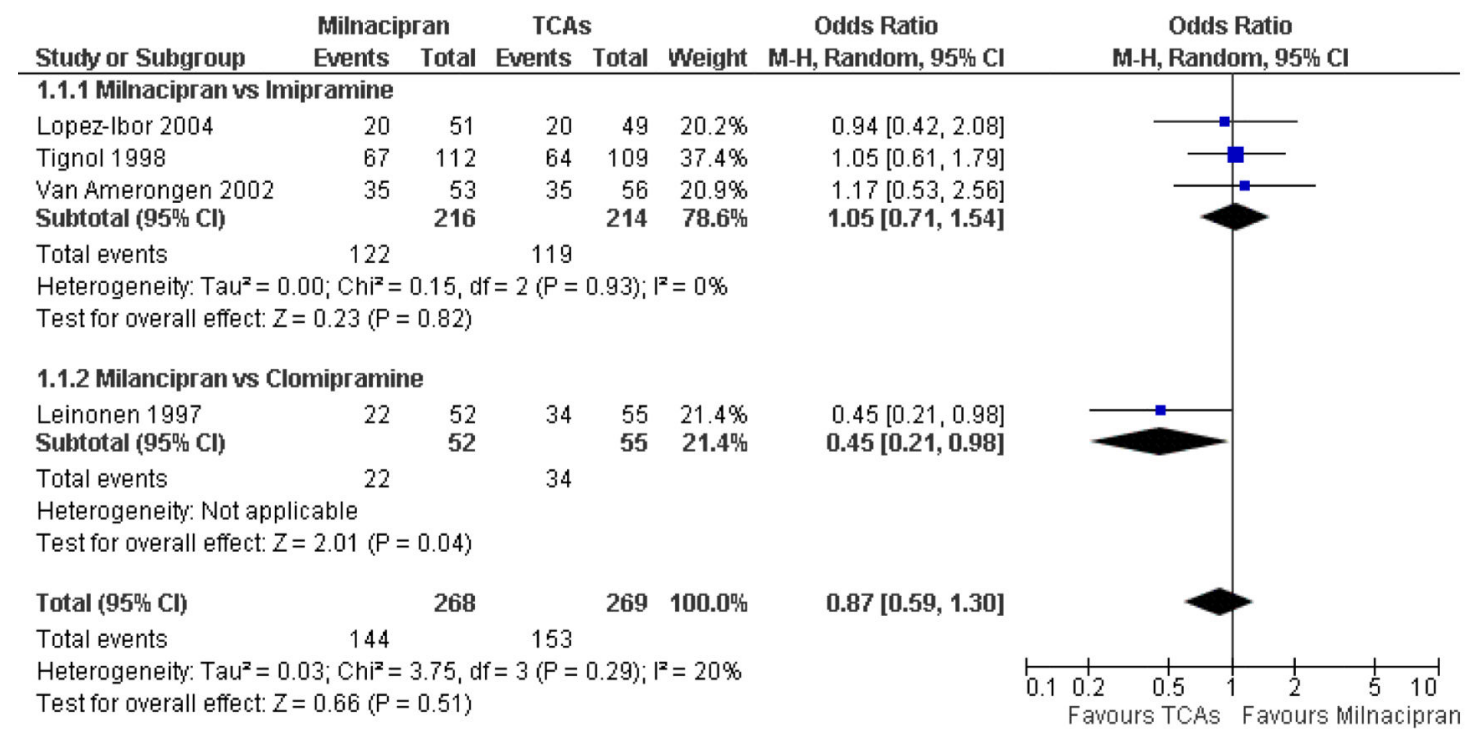

Figure 3. Forest plot of comparison: 1 Response at acute phase (6-12 weeks), outcome: 1.1 Milnacipran vs TCAs 


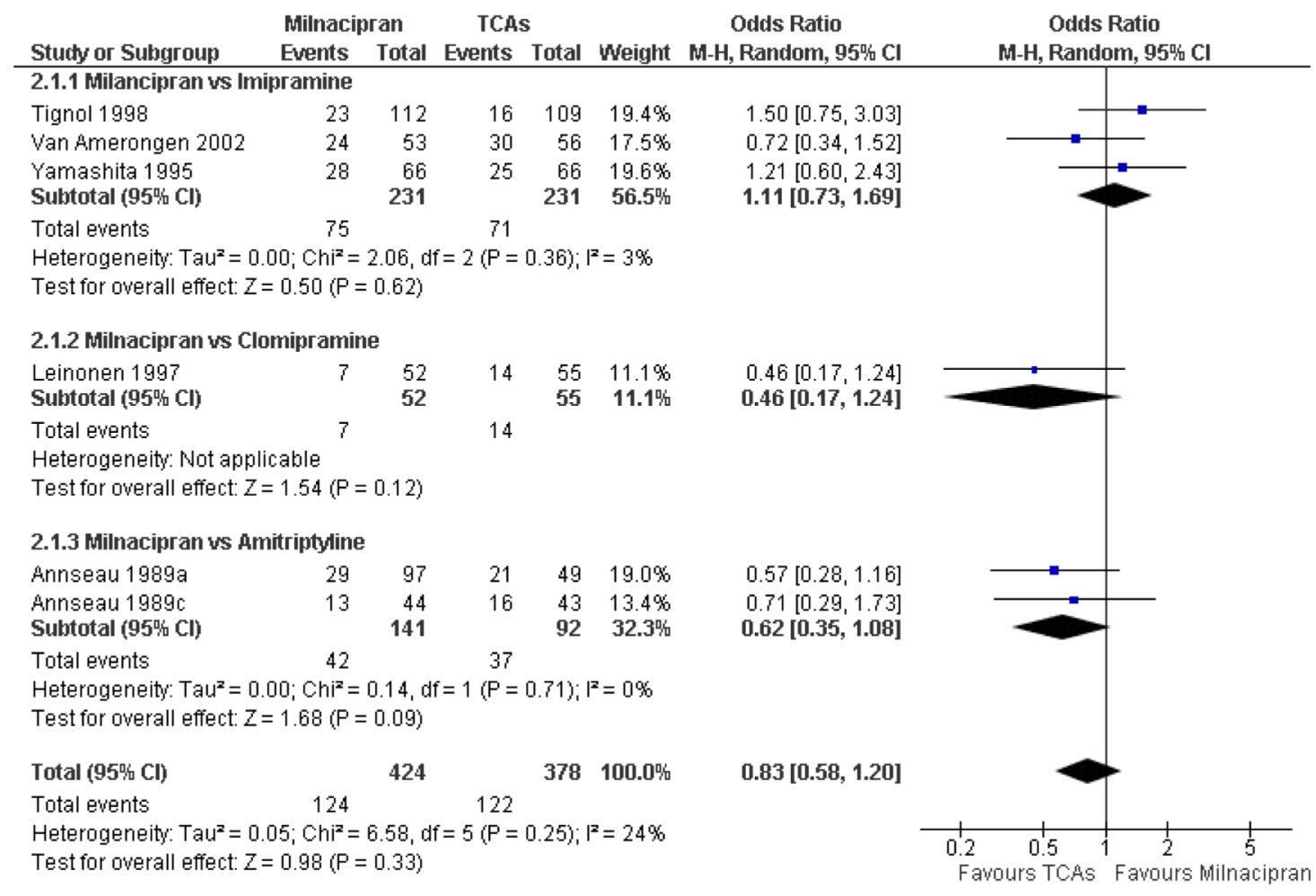

Figure 4. Forest plot of comparison: 2 Response at early phase (1-4 weeks), outcome: 2.1 Milnacipran vs TCAs 


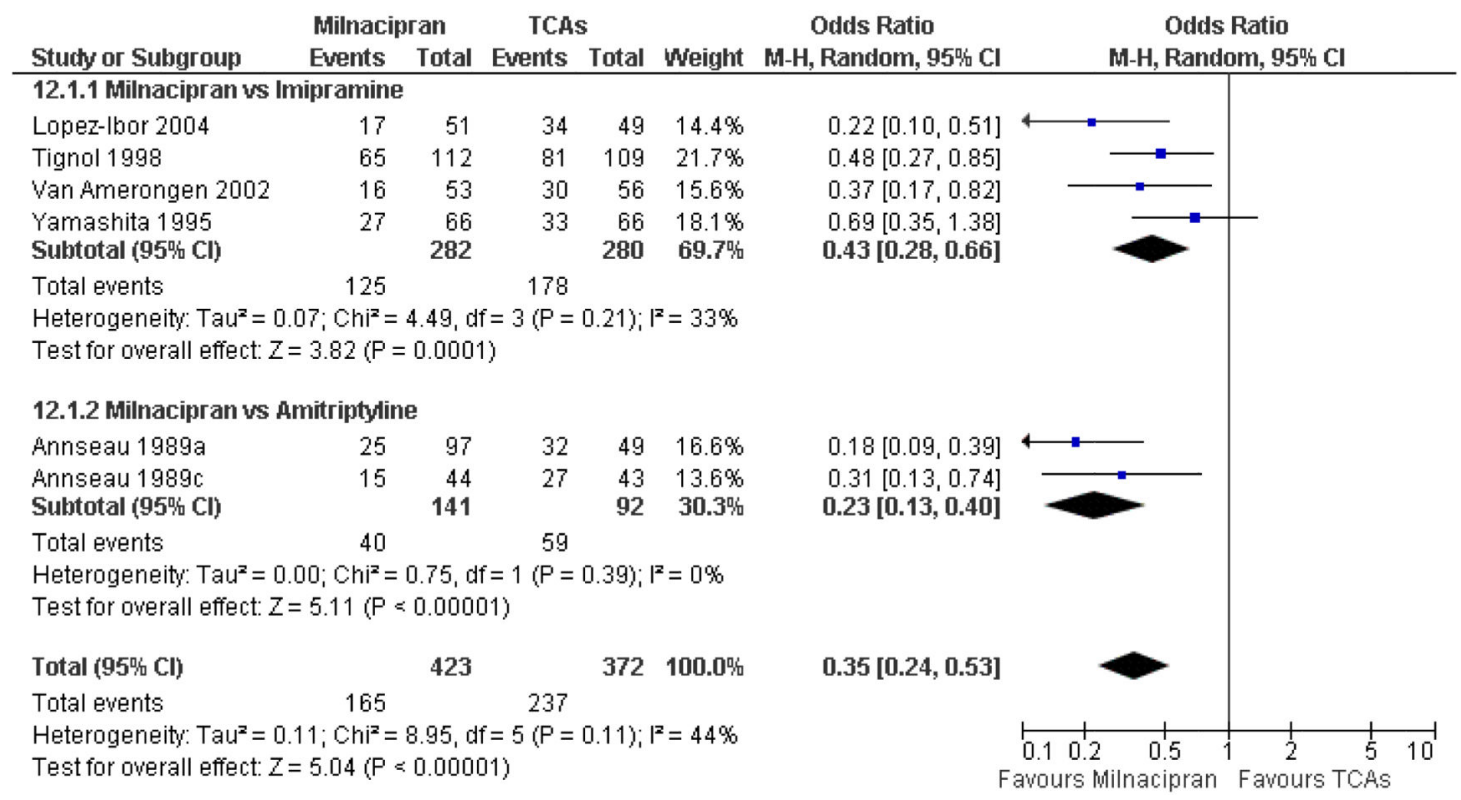

Figure 5. Forest plot of comparison: 12 Patients with at least some adverse events (Tolerability), outcome: 12.1 Milnacipran vs TCAs 


\begin{tabular}{|c|c|c|c|c|c|c|c|c|}
\hline \multirow[b]{2}{*}{ Stucty or Subgroup } & \multicolumn{2}{|c|}{ Milnacipran } & \multicolumn{2}{|c|}{ TCAS } & \multirow[b]{2}{*}{ Weight } & \multirow{2}{*}{$\begin{array}{l}\text { Odds Ratio } \\
\text { M-H, Random, 95\% } \mathrm{Cl}\end{array}$} & \multirow{2}{*}{$\begin{array}{l}\text { Odds Ratio } \\
\text { M-H, Random, 95侣 CI }\end{array}$} & \\
\hline & Events & Total & Events & Total & & & & \\
\hline \multicolumn{9}{|c|}{ 3.1.1 Milnacipran ws Clomipramine } \\
\hline $\begin{array}{l}\text { Leinonen } 1997 \\
\text { Subtotal (95听 Cl) }\end{array}$ & 27 & $\begin{array}{l}52 \\
52\end{array}$ & 33 & $\begin{array}{l}55 \\
55\end{array}$ & $\begin{array}{l}100.0 \% \\
\mathbf{1 0 0 . 0} \%\end{array}$ & $\begin{array}{c}0.72[0.33,1.55] \\
\mathbf{0 . 7 2}[\mathbf{0 . 3 3}, \mathbf{1 . 5 5}]\end{array}$ & & \\
\hline \multicolumn{9}{|c|}{$\begin{array}{l}\text { Heterogeneity: Not applicable } \\
\text { Test for overall effect: } Z=0.84(P=0.40)\end{array}$} \\
\hline Total (95\% Cl) & & 52 & & 55 & 100.0 劼 & $0.72[0.33,1.55]$ & & \\
\hline Total events & 27 & & 33 & & & & & \\
\hline $\begin{array}{l}\text { Heterogeneity: Not a } \\
\text { Test for overall effec }\end{array}$ & $\begin{array}{l}\text { plicable } \\
Z=0.84\end{array}$ & $=0.40$ & & & & & $\begin{array}{ccccc}0.1 & 0.2 & 0.5 & 1 & 2 \\
& \text { Fawours TCAS } & \text { Favours Mi }\end{array}$ & $\begin{array}{c}510 \\
510 \\
\text { Milnacipra }\end{array}$ \\
\hline
\end{tabular}

Figure 6. Forest plot of comparison: 3 Response at follow-up phase (4-6 months), outcome: 3.1 Milnacipran vs TCAs 


\begin{tabular}{|c|c|c|c|c|c|c|c|}
\hline \multirow[b]{2}{*}{ Stucby or Subgroup } & \multicolumn{2}{|c|}{ Milnacipran } & \multicolumn{2}{|c|}{ Heterocyclics } & \multirow[b]{2}{*}{ Weight } & \multirow{2}{*}{$\begin{array}{c}\text { Odds Ratio } \\
\text { M-H, Random, } 95 \text { 饰 Cl }\end{array}$} & \multirow{2}{*}{$\begin{array}{c}\text { Odds Ratio } \\
\text { hi-H, Random, } 95 \% \text { Cl }\end{array}$} \\
\hline & Events & Total & Events & Total & & & \\
\hline \multicolumn{8}{|c|}{ 2.3.1 Milancipran vs Mianserin } \\
\hline $\begin{array}{l}\text { Endo } 1995 \\
\text { Subtotal (95\% Cl) }\end{array}$ & 19 & $\begin{array}{l}84 \\
84\end{array}$ & 20 & $\begin{array}{l}95 \\
95\end{array}$ & $\begin{array}{l}100.0 \% \\
100.0 \%\end{array}$ & $\begin{array}{r}1.10[0.54,2.23] \\
1.10[0.54,2.23]\end{array}$ & \\
\hline \multicolumn{8}{|c|}{$\begin{array}{l}\text { Heterogeneity: Not applicable } \\
\text { Test for overall effect: } Z=0.25(P=0.80)\end{array}$} \\
\hline Total events & 19 & & 20 & & & & \\
\hline $\begin{array}{l}\text { Heterogeneity: Not a } \\
\text { Test for overall effect }\end{array}$ & $\begin{array}{l}\text { pplicable } \\
Z=0.25(\end{array}$ & $=0.80$ & & & & & $\begin{array}{|cccccc|}0.1 & 1 & 1 & 1 & 1 & 1 \\
0.1 & 0.5 & 1 & 2 & 5 & 10 \\
\text { Favours Heterocyclics } & \text { Favours Milnacipran }\end{array}$ \\
\hline
\end{tabular}

Figure 7. Forest plot of comparison: 2 Response at early phase (1-4 weeks), outcome: 2.3 Milnacipran vs Hererocyclics 


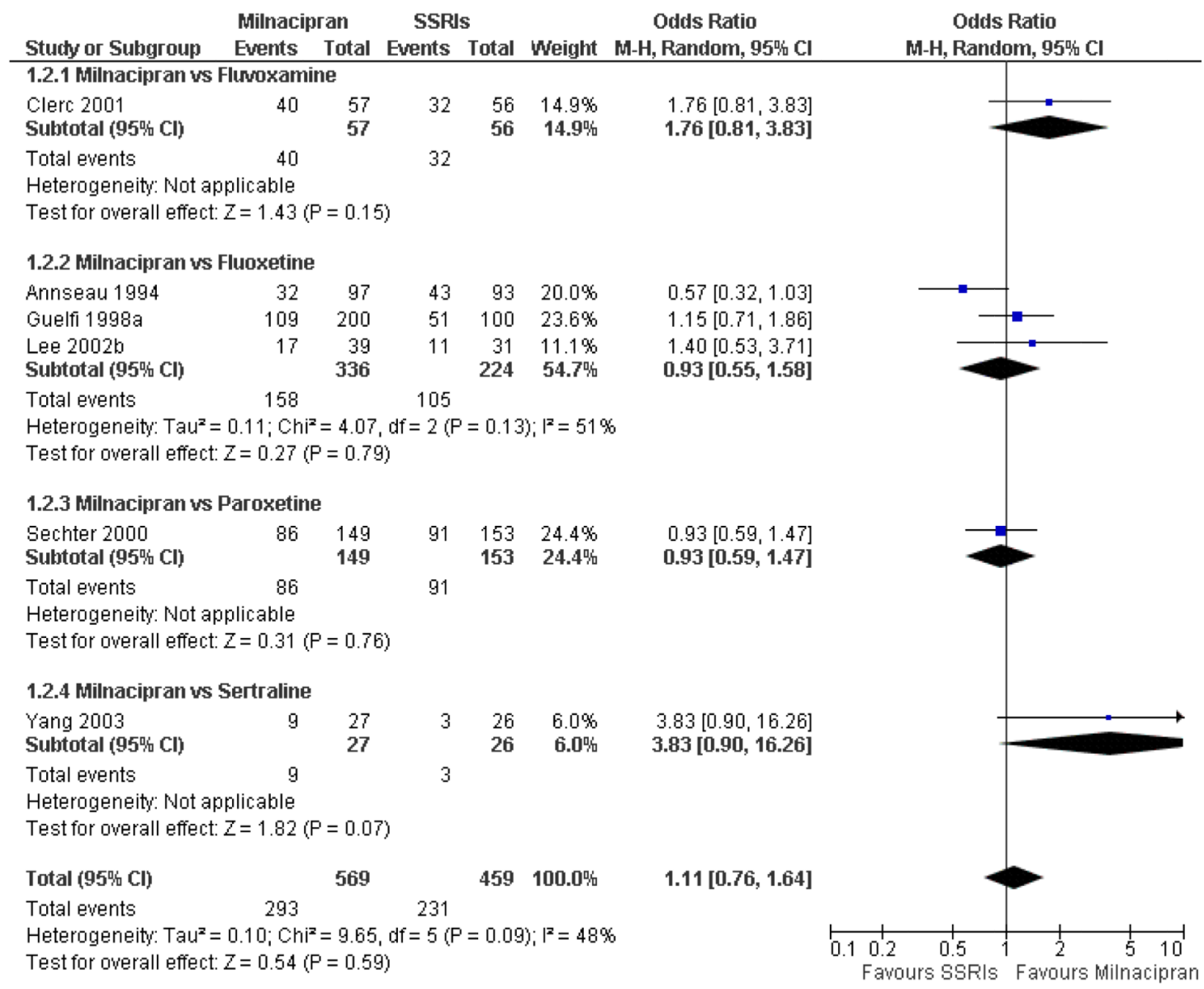

Figure 8. Forest plot of comparison: 1 Response at acute phase (6-12 weeks), outcome: 1.2 Milnacipran vs SSRIs 
Milnacipran SSRs Odds Ratio Odds Ratio

Study or Subgroup Events Total Events Total Weight $\mathrm{M}-\mathrm{H}$, Random, 95\% Cl 2.2.1 Milnacipran ws Fluwoxamine

Annseau $1991 \mathrm{c}$

Clerc 2001

Subtotal (95吹 Cl)

$32 \quad 8$

$86 \quad 10 \quad 41 \quad 11.9 \%$

$1.84[0.80,4.24]$

$\begin{array}{lllll}22 & 57 & 18 & 56 & 13.9 \%\end{array}$

$1.33[0.61,2.88]$

Total events

54 28

Heterogeneity: Tau $^{2}=0.00 ; \mathrm{Chi}^{2}=0.31, \mathrm{df}=1(\mathrm{P}=0.58) ; \mathrm{I}^{\mathrm{z}}=0 \%$

Test for overall effect: $Z=1.49(\mathrm{P}=0.14)$

2.2.2 Milnacipran us Fluoxetine

$\begin{array}{lrrrrrr}\text { Guelfi 1998a } & 83 & 200 & 31 & 100 & 32.2 \% & 1.58[0.95,2.63] \\ \text { Lee 2002b } & 8 & 39 & 6 & 31 & 6.0 \% & 1.08[0.33,3.51] \\ \text { Subtotal (95寉 Cl) } & & 239 & & \mathbf{1 3 1} & \mathbf{3 8 . 2} \% & \mathbf{1 . 4 9}[\mathbf{0 . 9 3}, \mathbf{2 . 3 7}] \\ \text { Total events } & 91 & & 37 & & & \end{array}$

Heterogeneity: $\mathrm{Tau}^{2}=0.00 ; \mathrm{Ch}^{2}=0.34, \mathrm{df}=1(\mathrm{P}=0.56)^{2} \mathrm{I}^{2}=0 \%$

Test for overall effect: $Z=1.66(P=0.10)$

\subsubsection{Milnacipran us Paroxetine}

Sechter 2000

Shinkai 2004

Subtotal (95\% Cl)

$38 \quad 149$

$10 \quad 20$

$\begin{array}{rrr}37 & 153 & 30.6 \% \\ 13 & 21 & 5.4 \% \\ & 174 & 36.0 \%\end{array}$

$1.07[0.64,1.81]$

$0.62[0.18,2.13]$

Total events

48
50

Heterogeneity: Tau $^{2}=0.00 ; \mathrm{Chi}^{2}=0.65, \mathrm{df}=1(\mathrm{P}=0.42) ; \mathrm{I}^{2}=0 \%$

Test for overall effect: $Z=0.05(\mathrm{P}=0.96)$

Total (95\% Cl)

551

$402100.0 \%$

Total events

193 115

Heterogeneity: Tau $^{2}=0.00 ; \mathrm{Chi}^{2}=3.23, \mathrm{df}=5(\mathrm{P}=0.66) ; \mathrm{I}^{2}=0 \%$

Test for overall effect: $Z=1.76(P=0.08)$

$0.99[0.61,1.60]$

M-H, Random, 95吹 Cl

Figure 9. Forest plot of comparison: 2 Response at early phase (1-4 weeks), outcome: 2.2 Milancipran vs SSRIs 
Table 1

Comparative efficacy and acceptability of milnacipran for acute major depression

\begin{tabular}{llll}
\hline & MTM (Cipriani 2009a) & Current review & \\
\hline OR (95\% CI) & OR $(95 \% \mathbf{C I})$ & Relative ratio of ORs $^{\boldsymbol{a}}$ \\
\hline Efficacy (response rate) & & & \\
\hline Fluvoxamine & $1.03(0.73-1.47)$ & $1.76(0.81-3.83)$ & 0.59 \\
\hline Fluoxetine & $1.01(0.76-1.35)$ & $0.93(0.55-1.58)$ & 1.09 \\
\hline Paroxetine & $1.00(0.74-1.33)$ & $0.93(0.59-1.47)$ & 1.08 \\
\hline Sertraline & $0.81(0.60-1.11)$ & $3.83(0.90-16.26)$ & 0.21 \\
\hline Acceptability (total dropout rate) & & & \\
\hline Fluvoxamine & $0.85(0.57-1.32)$ & $0.82(0.36-1.86)$ & 1.03 \\
\hline Fluoxetine & $1.03(0.76-1.45)$ & $1.02(0.71-1.46)$ & 1.01 \\
\hline Paroxetine & $0.94(0.68-1.31)$ & $0.88(0.50-1.54)$ & 1.07 \\
\hline Sertraline & $1.17(0.84-1.72)$ & $1.70(0.57-5.05)^{b}$ & 0.69 \\
\hline
\end{tabular}

For efficacy, OR higher than 1 favour milnacipran. For acceptability, OR lower than 1 favour milnacipran .

Abbreviations: $\mathrm{MTM}=$ multiple-treatments meta-analysis, $\mathrm{OR}=$ odds ratio, $\mathrm{CI}=$ confidence interval

${ }^{a}$ ORs of the current review as reference.

${ }^{b}$ Two trials comparing milnacipran with fluvoxamine (Annseau 1991c) and with sertraline (Shinkai 2004) were excluded because these 4-week trials were not included in MTM. 